Heloisa Fischer de Medeiros Pires

Impactos da Linguagem Simples na compreensibilidade da informação em governo eletrônico:

o caso de um benefício do INSS

\begin{abstract}
Dissertação de Mestrado
Dissertação apresentada como requisito parcial para obtenção do grau de Mestre pelo Programa de Pós-graduação em Design do Departamento de Artes e Design da PUC-Rio.
\end{abstract}

Orientadora: Profa. Claudia Renata Mont'Alvão Bastos Rodrigues

Co-orientadora: Profa. Erica dos Santos Rodrigues 
Heloisa Fischer de Medeiros Pires

\title{
Impactos da Linguagem Simples na compreensibilidade da informação em governo eletrônico: \\ o caso de um benefício do INSS
}

\begin{abstract}
Dissertação apresentada como requisito parcial para obtenção do grau de Mestre pelo Programa de PósGraduação em Design da PUC-Rio. Aprovada pela Comissão Examinadora abaixo.
\end{abstract}

Profa. Claudia Renata Mont'Alvão Bastos Rodrigues Orientadora Departamento de Artes e Design - PUC-Rio

Profa. Erica dos Santos Rodrigues Coorientadora Departamento de Letras - PUC-Rio

Profa. Carla Galvão Spinillo Departamento de Design - Universidade Federal do Paraná

Profa. Maria do Carmo Leite Oliveira Departamento de Letras - PUC-Rio

Rio de Janeiro, 15 de abril de 2021 
Todos os direitos reservados. É proibida a reprodução total ou parcial do trabalho sem autorização da universidade, da autora e da orientadora.

\section{Heloisa Fischer de Medeiros Pires}

Graduou-se em Comunicação Social na Escola de Comunicação (ECO) da Universidade Federal do Rio de Janeiro em 1988. Especializou-se em Cultura do Consumo na PUC-Rio em 2018. Fundou e dirigiu VivaMúsica!, empresa de comunicação que disseminou a música clássica no Brasil por 21 anos. Fundou e dirige a assessoria de aprendizagem Comunica Simples. Dá aulas, treinamentos e palestras.

Ficha Catalográfica

Pires, Heloisa Fischer de Medeiros

Impactos da linguagem simples na compreensibilidade da informação em governo eletrônico : o caso de um benefício do INSS / Heloisa Fischer de Medeiros Pires ; orientadora: Claudia Renata Mont'Alvão Bastos Rodrigues ; co-orientadora: Erica dos Santos Rodrigues. - 2021.

263 f. ; $30 \mathrm{~cm}$

Dissertação (mestrado)-Pontifícia Universidade Católica do Rio de Janeiro, Departamento de Artes e Design, 2021.

Inclui bibliografia

1. Artes e Design - Teses. 2. Linguagem simples. 3. Compreensibilidade textual. 4. Governo eletrônico. 5. Design da informação. 6. Burocratês. I. Rodrigues, Claudia Renata Mont'Alvão Bastos. II. Rodrigues, Erica dos Santos. III. Pontifícia Universidade Católica do Rio de Janeiro. Departamento de Artes e Design. IV. Título.

CDD: 700 
Para Luiz Alfredo Moraes (in memorian), um adepto da informação com leveza e com clareza que foi beneficiário do Auxílio-doença em 2016 


\section{Agradecimentos}

Às professoras Claudia Mont'Alvão e Erica dos Santos Rodrigues, pelo apoio, pela partilha de ensinamentos e, sobretudo, pelas preciosas orientações.

À agência de fomento CAPES, pela bolsa que possibilitou realizar esta pesquisa. Às professoras Carla Spinillo e Maria do Carmo Leite Oliveira, pelas importantes contribuições que deram ao integrar a banca de defesa do mestrado.

À professora Kelli CAS Smythe, pela leitura crítica dessa dissertação. À professora Sandra Korman, pelo incentivo a cursar a pós-graduação.

Aos que participaram do estudo experimental e aos especialistas que validaram a reescrita do texto sobre o Auxílio-doença, pelo tempo dedicado durante a pandemia.

Aos colegas que atuam na democratização de acesso à informação pública, em especial Isabel Ferreira Lima. A Priscila Reinaldo, do INSS, pelos contatos que viabilizou.

A Adriana Barros, pelo apoio operacional. A Zeca de Mello, pelo encorajamento.

A Clara Fischer Gam, pelo peer review sempre certeiro e incondicional. Aos familiares e amigos, pela confiança que o biênio de sumiço iria ser recompensador.

Ao amado Sérgio Rodrigues, por acolher o mestrado que calhou de ser justo nos primeiros anos de nosso casamento, e também pela paciência, carinho e ajuda.

"O presente trabalho foi realizado com apoio da Coordenação de Aperfeiçoamento de Pessoal de Nível Superior - Brasil (CAPES) - Código de Financiamento 001.” 


\section{Resumo}

Pires, Heloisa Fischer de Medeiros; Mont'Alvão, Claudia; Rodrigues, Erica dos Santos. Impactos da Linguagem Simples na compreensibilidade da informação em governo eletrônico: o caso de um benefício do INSS. Rio de Janeiro, 2021. 263p. Dissertação de Mestrado - Departamento de Artes e Design, Pontifícia Universidade Católica do Rio de Janeiro.

A oferta de serviços públicos digitais (e-serviços) avança no Brasil, mas a população tem dificuldade para se engajar. Uma queixa comum é achar o contato com o governo pela internet complicado. Os obstáculos para interagir com governo eletrônico vêm sendo discutidos sem confrontar o papel do burocratês, o estilo textual do setor público. Este estudo investigou como o estilo textual pode influenciar na compreensibilidade de informações sobre e-serviços, e em que medida o burocratês gera dúvidas de compreensão em leitores proficientes. A pesquisa articulou conceitos sobre compreensibilidade textual na Ergonomia, Design da Informação e Psicolinguística; examinou características linguísticas do burocratês; reuniu informações sobre habilidades de leitura dos brasileiros; reuniu informações sobre o movimento e a técnica Linguagem Simples; averiguou o estágio de digitalização de serviços públicos federais. Fez um levantamento documental de diretrizes de Linguagem Simples em onze governos internacionais e nacionais. Conduziu um estudo experimental em que 42 adultos com pósgraduação em diferentes áreas leram um texto sobre o benefício Auxílio-doença conforme o site do INSS e na versão reescrita em Linguagem Simples, aferindo a compreensão em cada condição. A versão em Linguagem Simples gerou mais acertos na primeira leitura, suscitou menos releituras e demandou menos tempo para completar o teste de compreensão. O experimento também mediu a percepção de usar textos e sites governamentais, que foi igual nos grupos: informações em sites e aplicativos são confusas e difíceis de entender, textos não se preocupam em facilitar a vida dos usuários, que preferem buscar informações em sites independentes. 


\section{Palavras-chave}

Linguagem Simples, compreensibilidade textual, governo eletrônico, Design da Informação, burocratês 


\section{Abstract}

Pires, Heloisa Fischer de Medeiros; Mont'Alvão, Claudia (Advisor); Rodrigues, Erica dos Santos (Co-advisor). Impacts of Plain Language on the comprehensibility of information in e-government: the case of a Brazilian Social Security (INSS) benefit. Rio de Janeiro, 2021. 263p. MSc Dissertation - Departamento de Artes e Design, Pontifícia Universidade Católica do Rio de Janeiro.

The provision of digital public services (e-services) is advancing in Brazil, but the population struggles to engage. A common complaint is that dealing with the government online is complicated. Barriers to interaction with e-government have been discussed without further exploring the role of 'officialese', the public sector's textual style. This study investigated how textual style can affect the comprehensibility of information about e-services and how confusing officialese can be, even to proficient readers. The research was based on textual comprehensibility concepts in Ergonomics, Information Design, and Psycholinguistics; it examined linguistic characteristics of officialese; gathered information on the reading skills of Brazilians; gathered information about the Plain Language movement and technique; and investigated the level of digitalization of federal services in Brazil. The research first examined Plain Language guideline documents from eleven governments, both national and international. Next, an experimental study was conducted in which 42 adults with post-graduate degrees in different areas read two versions of a text about Sickness Benefit. One as it appeared on the INSS website, and another version rewritten in Plain Language assessing comprehension in each condition. The Plain Language version scored a higher number of correct answers on first reading, prompted fewer re-readings of the text, and required less time to complete the comprehension test. The experiment also assessed the user-experience of government texts and websites: it was the same for the majority of participants. Information on government websites and apps is confusing and difficult to understand, and there is little concern about making things easier for users, who instead prefer to search for information on independent websites. 


\section{Keywords}

Plain Language, textual comprehensibility, e-government, Information Design, officialese 


\section{Sumário}

1. Introdução 22

1.1. Contexto 22

1.2. Tema, problema e objeto da pesquisa 25

1.3. Objetivos geral e específico 26

1.4. Metodologia $\quad 27$

1.5. Variáveis, hipótese e previsões 28

1.6. Motivação, relevância e contribuições da pesquisa 30

1.7. Estrutura da dissertação 32

2. Compreensibilidade textual 34

2.1. Compreensibilidade, leiturabilidade, inteligibilidade

e legibilidade 34

2.1.1. Termos em inglês e escolhas de tradução 35

2.1.2. Definição dos termos 37

2.2. Compreensibilidade textual na perspectiva da Ergonomia 38

2.2.1. Compreensão como tarefa mental 39

2.2.2. Modelo de processamento de Wogalter 40

2.2.3. Ruídos e problemas ergonômicos $\quad 42$

2.2.4. Aspectos do texto fácil de entender 43

2.3. Compreensibilidade textual na perspectiva do

Design da Informação $\quad 44$

2.3.1. Informação, memória e entendimento 45

2.3.2. Aspectos que prejudicam a leitura 46

2.3.3. Características da informação fácil de entender 47

2.4. Compreensibilidade textual na perspectiva da

$\begin{array}{ll}\text { Psicolinguística } & 47\end{array}$

2.4.1. Compreensão como processo cognitivo 48

2.4.2. Processamento lexical, sintático e textual 49

2.4.3. Modelo de processamento e possíveis fontes de problemas de compreensão $\quad 51$ 
3. Estilo textual do setor público (burocratês)

3.1. Definição de burocratês e suas traduções

3.2. Características linguísticas do burocratês que afetam a compreensibilidade textual em três idiomas

3.2.1. Português

3.2.2. Espanhol 60

3.2.3. Inglês

3.3. Habilidade da população brasileira para ler textos em burocratês

3.3.1. Dados do IBGE 64

3.3.2. Dados do INAF $\quad 65$

3.3.3. Dados do PISA 68

3.4. Leis e programas federais que determinam informação $\begin{array}{ll}\text { pública fácil de compreender } & 71\end{array}$

3.5. Síntese do capítulo $3 \quad 74$

4. Linguagem Simples (Plain Language) 75

4.1. Traduções e definições $\quad 75$

4.2. Movimento social pela clareza na informação pública 78

4.2.1. Cronologia do movimento internacional: anos 1940-2010 79

4.3. Técnica de comunicação: de descentralizada a padronizada 87

4.4. Críticas ao movimento e à técnica 92

4.5. Adoção de Linguagem Simples pelo setor público brasileiro 94

4.6. Síntese do capítulo $4 \quad 98$

5. Governo eletrônico (e-gov) 100

5.1. Definição de termos 100

5.2. Reengenharia de serviços anterior à digitalização 103

5.3. Vantagens, barreiras à interação e habilidades necessárias $\begin{array}{ll}\text { aos cidadãos } & 104\end{array}$

5.4. Governo eletrônico no Brasil 109 
5.4.1. Política norteadora vigente 109

5.4.2. Serviços públicos federais: estágio de digitalização 111

5.4.2.1. Digitalização de atendimentos no INSS 112

5.4.3. Orientações sobre informação fácil de compreender 116

5.5. Linguagem Simples em portais nacionais de serviços 118

5.6. Síntese do capítulo 5

6. Levantamento documental 123

6.1. Objetivos e critérios 124

6.2. Documentos com diretrizes governamentais

de Linguagem Simples $\quad 125$

6.2.1. Documentos em língua inglesa $\quad 125$

6.2.2. Documentos em língua espanhola 127

6.2.3. Documentos em língua portuguesa 128

6.3. Categorização e agrupamento das diretrizes 130

6.4. Quadros de diretrizes por áreas de concentração 133

6.4.1. Princípios norteadores 133

6.4.2. Estrutura da informação 134

6.4.3. Recursos visuais 135

6.4.4. Escolha de palavras 135

6.4.5. Construção de frases 136

6.4.6. Construção de parágrafos 137

6.4.7. Ações de avaliação 137

6.5. Lista das diretrizes governamentais mais recorrentes 138

6.6. Discussão dos resultados do levantamento documental 139

7. Estudo experimental 143

7.1. Projeto do experimento 144

7.2. Participantes do experimento 146

$\begin{array}{ll}\text { 7.3. Materiais } & 149\end{array}$

7.3.1. Texto do Auxílio-doença original no site do INSS

(Texto Burocratês) 150

7.3.1.1. Análise de complexidade 153 
7.3.1.2. Análise de complexidade complementar, usando

a ferramenta Coh-Metrix Port 3.0

7.3.2. Texto do Auxílio-doença reescrito em Linguagem Simples

(Texto Simplificado)

7.3.2.1. Check-list de complexidade: Texto Simplificado e

Texto Burocratês

7.3.3. Texto usado como medida de uniformização

7.3.4. Texto do cenário experimental

7.3.5. Teste para verificar compreensão e retenção das informações

165

7.3.6. Questionários

7.4. Procedimentos

7.4.1. Teste-piloto

7.4.2. Atividade experimental

7.4.3. Análise e organização dos dados $\quad 174$

7.5. Resultados

7.5.1. Métricas de leitura em voz alta

7.5.2. Teste de compreensão: Número de acertos após a primeira leitura (variável dependente 1)

7.5.3. Teste de compreensão: Número de releituras para ajustar ou conferir respostas (variável dependente 2)

7.5.4. Teste de compreensão: Tempo para completar

o teste (variável dependente 3)

7.5.5. Questionário: Avaliação do texto sobre o Auxílio-doença

7.5.6. Questionário: Eventual pedido de Auxílio-doença

para si mesmo

7.5.7. Questionário: Avaliação de textos governamentais

na internet

7.5.8. Questionário: Avaliação de experiência recente de

uso de serviços públicos digitais - Nuvens de adjetivos

7.6. Discussão dos resultados do estudo experimental

7.6.1. Teste de compreensão

7.6.2. Questionários 
8. Análise geral da pesquisa e conclusões 200

8.1. Análise geral 200

8.2. Sintonia com o Zeitgeist (espírito do tempo) 203

8.3. Frutos 204

8.4. Desdobramentos e recomendações 205

$\begin{array}{ll}\text { 8.5. Conclusões } & 209\end{array}$

9. Referências bibliográficas 212

Apêndices $\quad 231$

Apêndice 1 - Como foram atribuídas 56 palavras-chave

às diretrizes governamentais de Linguagem Simples 231

Apêndice 2 - Termo de Consentimento Livre e Esclarecido 239

Apêndice 3 - Teste de compreensão: Critérios que orientaram

a elaboração das afirmativas

Apêndice 4 - Questionário: Transcrição e categorização

das respostas em voz alta à pergunta "O que poderia ter sido

exposto de modo mais claro no texto?"

Apêndice 5 - Questionário: Lista de adjetivos atribuídos à

experiência de usar serviços públicos na internet

Apêndice 6 - Teste de compreensão: Scores individuais

das três variáveis dependentes do estudo experimental

\section{Anexos}

Anexo 1 - Reprodução da primeira página das diretrizes gover-

namentais de Linguagem Simples do levantamento

Anexo 2 - Parecer da Comissão da Câmara de Ética em Pesquisa

da PUC-Rio 056/2020 - Protocolo 76/2020

Anexo 3 - Impressões de tela da seção de avaliações e resenhas de usuários do aplicativo Meu INSS, na Play Store Google 


\section{Lista de figuras}

Figura 1: Diagrama representando as etapas das fases qualitativa e quantitativa da pesquisa

Figura 2 - Frequência dos termos readability, legibility, comprehensibility e inteligibility em fontes impressas nos corpora de texto do Google em inglês de 1550 até 2019

Figura 3 - Representação visual da relação semântica entre os termos readability, comprehensibility, inteligibility e legibility

Figura 4 - Modelo C-HIP de Wogalter 2006, em português

Figura 5 - Modelo de Compreensão Leitora de Perfetti com indicação de gargalos onde podem ocorrer problemas

Figura 6 - Painel de Monitoramento de Serviços Federais

Figura 7 - Avaliação dos serviços do INSS no Painel de Monitoramento de Serviços Federais

Figura 8 - Seção "Benefícios concedidos ou reajustados por decisão judicial”, como constava site do INSS em setembro/2020 152

Figura 9 - Página inicial da ferramenta computacional Coh-Metrix-Port 3.0 no site do NILC

Figura 10 - Tela do teste do estudo experimental para verificar compreensão e retenção de informações

Figura 11 - Reprodução da tela do estudo experimental que informava a possibilidade de reler o texto e revisar as respostas

Figura 12 - Boxplot do número de acertos no teste de compreensão após a primeira leitura (Burocratês e Simplificado)

Figura 13 - Boxplot do número de releituras para ajustar ou conferir respostas (Burocratês e Simplificado)

Figura 14 - Boxplot do tempo em segundos para completar o teste de compreensão (Burocratês e Simplificado) 
Figura 15 - Pergunta do questionário "Avaliação do texto sobre o Auxílio-doença": os participantes deviam responder em voz alta os aspectos pouco claros do texto

Figura 16 - Nuvem de adjetivos citados por participantes dos grupos para qualificar a experiência de usar sites de governo

Figura 17 - Nuvem de adjetivos citados por participantes do grupo Burocratês para qualificar a experiência de usar sites governamentais

Figura 18 - Nuvem de adjetivos citados por participantes do grupo Simplificado, para qualificar a experiência de usar sites governamentais 


\section{Lista de quadros}

Quadro 1 - Problemas do burocratês conforme

Mendonça (1987), Silveira (2008), Miguel (2000),

Casabone (2016), Danet (1983) e Aitchinson (1983)

62

Quadro 2 - Diretrizes governamentais de Linguagem Simples na área de concentração Princípios Norteadores

Quadro 3 - Diretrizes governamentais de Linguagem Simples na área de concentração Estrutura da Informação

Quadro 4 - Diretrizes governamentais de Linguagem Simples na área de concentração Recursos Visuais

Quadro 5 - Diretrizes governamentais de Linguagem Simples na área de concentração Escolha de Palavras

Quadro 6 - Diretrizes governamentais de Linguagem Simples na área de concentração Construção de Frases

Quadro 7 - Diretrizes governamentais de Linguagem Simples na área de concentração Construção de Parágrafos

Quadro 8: Diretrizes governamentais de Linguagem Simples na área de concentração Ações de Avaliação

Quadro 9 - Doze diretrizes governamentais de Linguagem

Simples mais recorrentes no levantamento, por área de concentração e número de governos que as indicam

Quadro 10 - Sete diretrizes governamentais de Linguagem Simples oriundas do levantamento documental que foram selecionadas para analisar o Texto Burocratês

Quadro 11 - Diagnóstico do Texto Burocratês conforme diretrizes governamentais de Linguagem Simples

Quadro 12 - Diagnóstico do Texto Burocratês no

Coh-Metrix Port 3.0, por parágrafos

Quadro 13 - Texto Burocratês, intervenções feitas na reescrita e Texto Simplificado, parágrafo por parágrafo

Quadro 14 - Check-list comparativo entre os textos 
Simplificado e Burocratês

Quadro 15 - Achados do teste de compreensão conforme o tipo de variável, a previsão nas tarefas de compreensão e os resultados 


\section{Lista de tabelas}

Tabela 1 - Níveis de instrução da população brasileira com

25 anos ou mais de idade

Tabela 2 - Níveis de alfabetismo da população brasileira entre 15 e 64 anos de idade

Tabela 3 - Níveis de competência em leitura de estudantes brasileiros e média dos resultados de estudantes dos países da OCDE no PISA 2018

Tabela 4 - Perfil dos participantes do estudo experimental

Tabela 5 - Tipos de interação que os participantes do estudo experimental já haviam tido com o INSS

Tabela 6 - Tempo (em segundos) de leitura em voz alta do texto que foi usado como medida de uniformização do estudo experimental

Tabela 7 - Tempo (em segundos) da leitura em voz alta dos textos sobre o Auxílio-doença

Tabela 8 - Número de caracteres lidos por segundo dos textos sobre o Auxílio-doença

Tabela 9 - Número de acertos no teste de compreensão após a primeira leitura

Tabela 10 - Resultado do teste Mann-Whitney para a variável dependente "Número de acertos após a primeira leitura"

Tabela 11 - Número de releituras para ajustar ou conferir respostas no teste de compreensão

Tabela 12 - Resultado do teste Mann-Whitney para a variável dependente "Número de releituras para conferir ou modificar respostas"

Tabela 13 - Tempo em segundos para completar o teste de compreensão

Tabela 14 - Resultado do teste-t Student para a variável 
Tabela 15 - Métricas do questionário para avaliar o texto sobre o Auxílio-doença que o participante leu

Tabela 16 - Queixas de falta de clareza nos textos Burocratês e Simplificado

Tabela 17 - Queixas sobre conteúdo informacional dos textos Burocratês e Simplificado

Tabela 18 - Métricas do questionário sobre um eventual pedido de Auxílio-doença do participante

Tabela 19 - Métricas do questionário sobre a experiência dos participantes com textos e sites governamentais 
Documentos mal elaborados são tão comuns que decifrar a má escrita e o mau design visual se tornaram parte das habilidades necessárias para navegar na chamada era da informação. 


\section{Introdução}

\subsection{Contexto}

Os termos "governo eletrônico" e "e-gov" são usados há mais de vinte anos para definir a prestação de serviços públicos por meio das tecnologias de informação e comunicação (UNITED NATIONS, 2018). A transformação digital de governos, que vinha avançando de forma gradual, foi acelerada pela pandemia do corona vírus. A crise sanitária intensificou o uso de canais digitais para divulgar informações, esclarecer dúvidas, prestar serviços e, principalmente, possibilitar o autoatendimento da população. No Brasil, por exemplo, o cadastro para receber Auxílio Emergencial ${ }^{1}$ foi feito exclusivamente pelo aplicativo da Caixa Econômica Federal, na modalidade autoatendimento. Mais de 66 milhões de pessoas foram atendidas na primeira distribuição desse benefício, em 2020 (AUXÍLIO, 2020).

A pandemia também acelerou os desafios da digitalização de governos: garantir que cidadãos e empresas acessem informações, processem serviços, usufruam de direitos e façam transações online com eficácia. E-govs priorizam o autoatendimento digital, reduzindo ou eliminando os canais de interação pessoal, o que reduz as possibilidades de esclarecer dúvidas de compreensão com humanos. Por isso, as informações devem ser fáceis de ler e entender.

Apesar de haver uma urgência por clareza, as informações públicas continuam sendo escritas no estilo típico da burocracia, presente em diversos idiomas. No Brasil, o estilo é dicionarizado como "burocratês" (HOUAISS; VILLAR, 2001). Caracteriza-se por usar elementos linguísticos que dificultam a

1 Benefício financeiro concedido pelo Governo Federal para trabalhadores informais, microempreendedores individuais (MEI), autônomos e desempregados como uma proteção emergencial durante a pandemia (CAIXA, s/d). 
leitura, tais como frases longas, ordem indireta, nominalizações e siglas (SILVEIRA, 2008; MENDONÇA, 1987; MIGUEL, 2000; CASABONE, 2016; DANET, 1983; AITCHINSON, 1986). Os prejuízos que o "burocratês" causa à cidadania no Brasil vêm sendo apontados desde os anos 1980 (MENDONÇA, 1987). Nas décadas seguintes, surgiram leis determinando informação pública clara e de fácil compreensão (BRASIL, 2011; BRASIL, 2017; BRASIL, 2015; BRASIL, 2018), mas houve pouca aderência.

Escrever informações sobre serviços públicos digitais de forma clara, concisa e objetiva, com palavras de uso frequente, evitando elementos linguísticos que dificultem a leitura, requer uma mudança estrutural na comunicação de governos. Neste sentido, é oportuno lembrar que a Organização das Nações Unidas estimula e-govs a promover mudanças que coloquem as pessoas em primeiro lugar, atendam as necessidades dos indivíduos e mitiguem os riscos associados ao uso das tecnologias (UNITED NATIONS, 2020, p. 180). Já o Banco Interamericano de Desenvolvimento aponta ser consensual em países desenvolvidos que, ao lidar com o Estado, "os cidadãos devem ser capazes de encontrar informações em uma linguagem e formato fáceis de entender" (ROSETH; REYES; SANTISO, 2018). Se os elementos linguísticos do "burocratês" prejudicam a compreensão de pessoas com alta escolaridade, o efeito é devastador entre os grupos menos escolarizados caso da maioria da população brasileira, que tem $29 \%$ de analfabetos funcionais e 34\% de alfabetizados em nível elementar (LIMA; CATELLI JR., 2018).

O Brasil foi um dos países pioneiros a aderir à transformação digital e tem uma trajetória de progresso em e-gov. Atualmente, a administração pública federal tem a meta de oferecer todos os seus serviços digitalmente até 2022 (BRASIL, 2020). O uso de internet é quase universal entre os brasileiros - $95 \%$ da população com mais de 16 anos acessam a internet pelo celular e 86,7\% têm acesso à internet wi-fi em casa (LAFUENTE ET AL., 2021) -, mas a adesão aos serviços públicos online ainda é baixa. Só $10 \%$ dos usuários de internet interagiram com e-gov de forma totalmente digital, sem precisar ir a um posto de atendimento. Considerar o contato com o governo pela internet complicado é um dos motivos mais citados para evitar o autoatendimento online (NÚCLEO DE INFORMAÇÃO E COORDENAÇÃO DO PONTO BR, 2020b, p. 78). Dificuldade ao usar o aplicativo da Caixa Econômica foi o motivo mais citado por usuários de internet que não conseguiram receber o Auxílio Emergencial (NÚCLEO DE INFORMAÇÃO E 
COORDENAÇÃO DO PONTO BR, 2020b, p. 77).

No que diz respeito à elaboração de textos mais fáceis de ler, existe um movimento social e uma técnica de comunicação conhecidos como Plain Language (Linguagem Simples), presentes em vários países desde os anos 1940. Ao longo das décadas, as diretrizes da Linguagem Simples foram sendo validadas empiricamente por atores sociais de diferentes áreas, em diversos idiomas, com pouco suporte de pesquisa. Por isso, reiterados estudos internacionais vêm recomendando a produção de conhecimento científico para avaliar os ganhos de compreensibilidade textual por meio de Linguagem Simples (GARWOOD, 2014; SCHRIVER, 2014; SCHRIVER, 2017).

Atualmente, diversos países recomendam usar Linguagem Simples em e-gov. A técnica chegou ao setor público brasileiro há cinco anos, por meio de cartilhas (GESPÚBLICA, 2016; FUNDAÇÃO SEADE, 2016) e debates ( $3^{\circ}$ ENCONTRO, 2018; ENCONTRO, 2019); bem como em políticas públicas da Prefeitura de São Paulo e do Governo do Estado do Ceará (SÃO PAULO, 2020; IRISLABGOV, s/d). Existe um projeto de lei tramitando na Câmara dos Deputados para instituir um Programa Nacional de Linguagem Simples (CÂMARA DOS DEPUTADOS, 2019). Essas iniciativas brasileiras vêm replicando diretrizes que são recomendadas por governos estrangeiros e foram validadas empiricamente em outros idiomas.

Estudos anteriores já problematizaram o "burocratês" na governança digital brasileira, recomendando a Linguagem Simples (BARBOZA; NUNES, 2008; BARBOZA, 2011). Também já foi avaliada a compreensibilidade textual em e-gov antes e depois da reescrita em Linguagem Simples, usando o Teste de Cloze (MARTINS; FILGUEIRAS, 2007). Porém, faltou a estas pesquisas:

- analisar os elementos linguísticos que criam barreiras à compreensão textual de informações em e-gov;

- avaliar a retenção de informações em e-gov antes e depois da reescrita;

- conhecer a percepção dos usuários sobre textos governamentais na internet e sobre o uso de serviços públicos digitais.

- identificar e sistematizar as diretrizes governamentais de Linguagem Simples

Considerando toda a conjuntura apresentada, decidiu-se conduzir a presente pesquisa com foco nos aspectos verbais (estilo de escrita) de textos sobre serviços 
públicos digitais. Os aspectos visuais (gráficos e tipográficos) dos textos ficaram propositadamente fora do recorte. Na seção 1.6 ("Justificativa da relevância da pesquisa"), serão apresentados subsídios adicionais para justificar o porquê de uma pesquisa em Design enfatizar somente os aspectos verbais.

A pesquisa articulou conceitos de compreensibilidade textual em Ergonomia, Design da Informação e Psicolinguística e examinou aspectos relativos ao "burocratês", à Linguagem Simples e a governos eletrônicos. Tal fundamentação possibilitou (i) sistematizar as diretrizes de Linguagem Simples em onze governos e (ii) conduzir um estudo experimental para analisar a compreensibilidade do benefício Auxílio-doença no site do Instituto Nacional do Seguro Social (INSS), antes e depois de reescrito em Linguagem Simples.

O Auxílio-doença é o benefício mais visitado do site do INSS e é a demanda mais recorrente em processos de direito previdenciário na Justiça Federal (PODER JUDICIÁRIO, 2020). Aferiu-se a compreensibilidade em adultos com pósgraduação, com formação acadêmica e experiência profissional distinta. O objetivo era verificar se, mesmo em um grupo de alta escolaridade, a intervenção em Linguagem Simples poderia reduzir custos de processamento associados à leitura de textos complexos, facilitando sua compreeensão. Resultados nessa direção representariam evidência de que o burocratês pode constituir um elemento dificultador ao acesso a informações públicas e, dessa forma, sensibilizar agentes públicos para a adoção e disseminação dos normativos em prol da clareza. As seções 4.4. ("Críticas ao movimento e à técnica") e 7.2. ("Participantes do experimento") trarão mais detalhes.

\section{2.}

\section{Tema, problema e objeto da pesquisa}

Tema - A compreensibilidade de textos governamentais online, sob a perspectiva do estilo de escrita.

Problema - Qual é o impacto do grau de complexidade do estilo de escrita na compreensibilidade textual de serviços públicos digitais? 
Objeto - Avaliação da compreensibilidade textual de um benefício do INSS a partir de intervenções nos elementos linguísticos de acordo com diretrizes de Linguagem Simples.

\section{3.}

\section{Objetivos geral e específicos}

\section{GERAL}

- Estimar o papel do estilo de escrita na compreensibilidade de informações sobre serviços públicos digitais.

\section{ESPECÍFICOS}

- Identificar as características linguísticas do "burocratês" que dificultam a leitura e prejudicam a compreensão de textos;

- Reunir informações sobre o movimento social e a técnica de comunicação Plain Language (Linguagem Simples) no contexto do setor público;

- Relatar as determinações do governo eletrônico brasileiro sobre o estilo de escrita dos textos;

- Localizar e esquematizar as diretrizes de Linguagem Simples que são usadas em governos eletrônicos internacionais e brasileiros;

- Examinar a estrutura linguística de um fragmento do texto sobre o benefício Auxílio-doença no site do INSS e analisar os seus elementos;

- Avaliar o impacto de diretrizes de Linguagem Simples na compreensibilidade do fragmento sobre o benefício Auxílio-doença no site do INSS, considerando a versão original do texto e a versão reescrita, por adultos de alta escolaridade;

- Conhecer aspectos relacionados à experiência de ler textos governamentais na internet e de usar serviços públicos digitais. 


\section{4. \\ Metodologia}

Esta pesquisa é de natureza exploratória, utilizando métodos mistos. Além da pesquisa bibliográfica sobre o tema, foi realizado levantamento documental e análises de caráter qualitativo e quantitativo, com aplicação de uma atividade experimental.

A etapa qualitativa abrangeu as seguintes fases:

- Revisão de literatura sobre compreensibilidade textual em Ergonomia, Design da Informação e Psicolinguística - para conhecer os problemas possíveis de ocorrer durante a leitura, os custos de processamento mental de informações e as estratégias para facilitação do entendimento de textos;

- Revisão de literatura sobre características linguísticas do "burocratês" para identificar elementos que são típicos da escrita do setor público e prejudicam a leitura de textos;

- Levantamento documental e revisão de literatura sobre Linguagem Simples - para traçar um panorama de como o movimento e a técnica chegaram até o setor público brasileiro;

- Levantamento documental e revisão de literatura sobre a clareza de informações em governo eletrônico e sobre o uso de Linguagem Simples em portais nacionais de serviço - para conhecer como o estilo textual interfere na compreensibilidade de informações públicas;

- Levantamento documental de diretrizes de Linguagem Simples atualmente recomendadas por oito governos estrangeiros e três entes governamentais brasileiros - para esquematizar as diretrizes mais recorrentes nesses onze governos. Os resultados desse levantamento foram integrados ao estudo experimental conduzido na etapa quantitativa;

- Análise de complexidade textual das informações sobre o Auxílio-doença no site do INSS - para identificar os elementos linguísticos que prejudicam a leitura e sinalizar as necessidades de intervenção na reescrita em Linguagem Simples. Os resultados dessa análise foram integrados ao estudo experimental conduzido na etapa quantitativa

A etapa quantitativa consistiu em um estudo experimental para avaliar o 
impacto da Linguagem Simples na compreensibilidade textual do benefício "Auxílio-doença" junto a 42 adultos com pós-graduação. Além de um teste de compreensão e retenção de informações sobre o benefício, os participantes responderam questionários para avaliar a compreensibilidade do texto do Auxíliodoença, para avaliar a experiência de interagir com textos governamentais na internet e para avaliar uma experiência recente sobre o uso de serviços públicos digitais. Os resultados do estudo experimental serão relatados nos capítulos 7 e 8 .

A Figura 1 representa graficamente as etapas percorridas pela pesquisa.

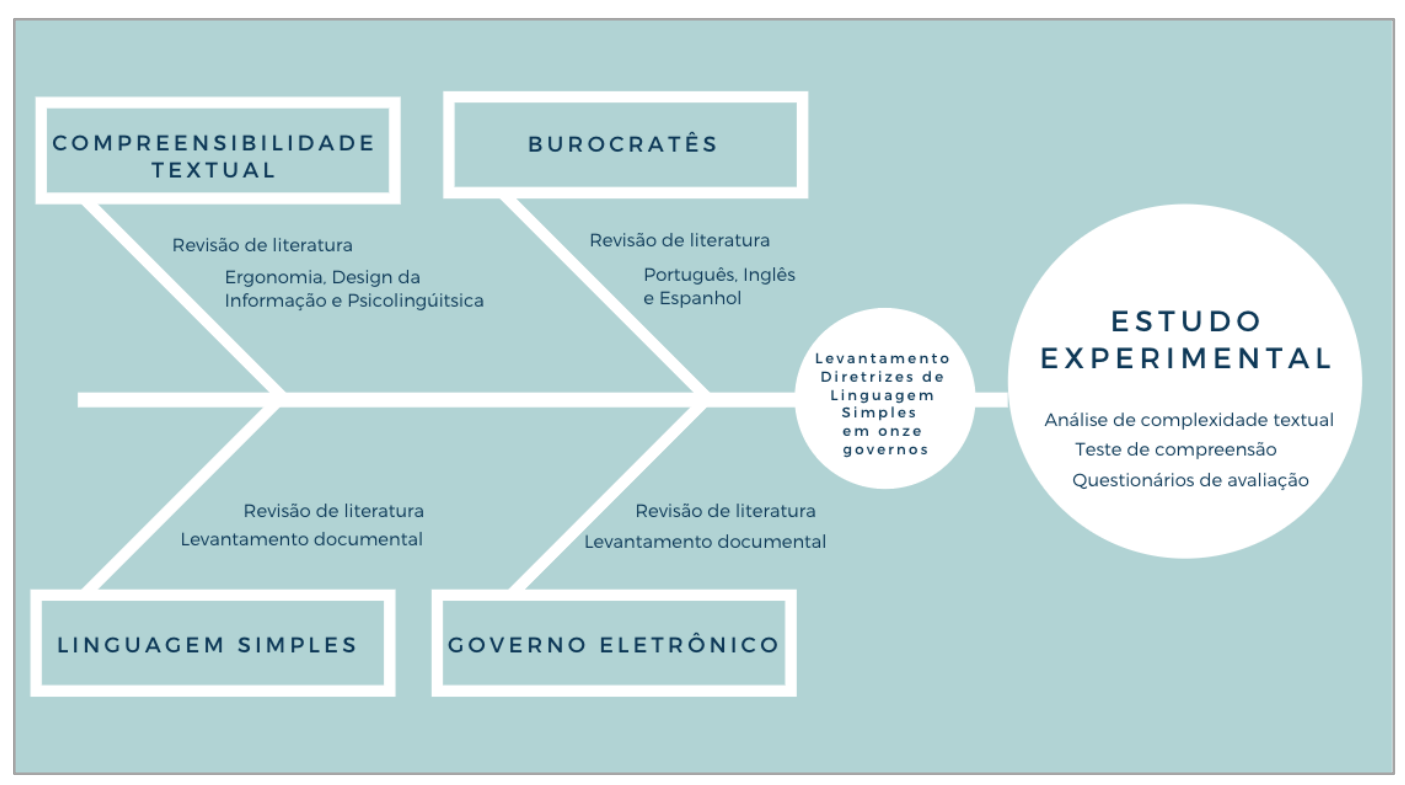

Figura 1: Diagrama representando as etapas das fases qualitativa e quantitativa da pesquisa

1.5 .

Variáveis, hipótese e previsões

A pesquisa conduziu um estudo experimental que trabalhou com as seguintes variáveis:

- Variável independente: Grau de complexidade textual. Essa variável foi manipulada para um grupo ler o texto sobre o benefício Auxílio-doença que consta do site do INSS e o outro grupo ler o mesmo texto reescrito conforme diretrizes de Linguagem Simples. 
- Variáveis dependentes: Número de acertos no teste de compreensão após a primeira leitura do texto; Número de releituras necessárias para conferir e/ou modificar as respostas; Tempo total para analisar e responder o teste de compreensão.

- Variáveis controladas: (i) Organização da informação e aspectos visuais o texto reescrito em Linguagem Simples replicou a formatação do texto original do INSS. Não sofreram alteração tipo e tamanho de fonte, uso de cores ou imagens; tamanhos de linha e entrelinha ou justificação dos parágrafos. (ii) Grau de escolaridade. Todos os participantes tinham pósgraduação completa ou em curso.

- Variáveis intervenientes: (i) Atuação profissional no setor público ou no campo do Direito; (ii) Ter pedido o benefício Auxílio-doença para si ou para terceiros.

O estudo experimental formulou uma hipótese de trabalho e três previsões em tarefa de compreensão:

- Hipótese de trabalho: A aplicação de parâmetros de Linguagem Simples à escrita de textos de e-gov reduz custos de processamento associados à leitura desses textos, aumentando sua compreensibilidade.

- Previsão 1: O texto em Linguagem Simples deverá gerar, em média, mais acertos no questionário do que a média de acertos do texto em burocratês.

- Previsão 2: O texto em Linguagem Simples demandará, em média, um número de releituras para conferir ou modificar respostas menor do que o texto em burocratês.

- Previsão 3: Perguntas sobre um texto em Linguagem Simples serão respondidas, na média, em menos tempo do que perguntas sobre um texto em burocratês. 


\section{6.}

\section{Motivação, relevância e contribuições da pesquisa}

A presente pesquisa atende várias demandas sobre o papel do Design da Informação e da Linguagem Simples em textos governamentais, além de responder a uma motivação pessoal.

Do ponto de vista administrativo-organizacional, as metas da Política de Governo Digital (BRASIL, 2020) estabelecem a digitalização de todos os serviços públicos federais até 2022 e classificam como prioritária a facilitação de uso desses serviços. Facilitar o uso de um serviço digital inclui, necessariamente, facilitar a linguagem que transmite as informações. Se o burocratês é um dos elementos que atrasa a transformação digital dos governos, esta pesquisa oferece subsídios para enfrentar o problema.

Do ponto de vista social-econômico, textos governamentais sempre foram difíceis e demorados de ler, obrigando cidadãos e órgãos públicos a perderem tempo, dinheiro e paciência para esclarecer dúvidas. Nas plataformas digitais, o burocratês tem causado prejuízos ainda maiores à cidadania, dada a escassez de suporte humano para dirimir dúvidas. Um relatório técnico do Banco Interamericano de Desenvolvimento (BID) quantificou o impacto da Linguagem Simples na redução de custos administrativos na Colômbia (CUESTA, REYES E ROSETH, 2019), recomendando investigações que avaliassem o papel dos elementos linguísticos na compreensão de textos governamentais. Esta pesquisa é uma resposta à recomendação do $\mathrm{BID}$, podendo contribuir com fundamentação para embasar estudos semelhantes aos da Colômbia, mas em língua portuguesa.

Do ponto de vista epistemológico, a pesquisa vincula-se a uma consolidada (porém aparentemente pouco reconhecida no Brasil) proximidade entre a Linguagem Simples e o Design da Informação. Durante o mestrado, ao apresentar a investigação com foco em aspectos verbais do texto, a pesquisadora precisou responder várias vezes à pergunta: "Por que investigar esse tema no Design? Designers não se ocupam da redação de textos! Você deveria estar em um programa de Estudos de Linguagem.”

Ocorre que, já nos anos 1970, designers britânicos como Michael McDonaldRoss e Rob Waller discutiam a interação entre palavras e imagens, vindo a influenciar gerações de colegas nos Estados Unidos e em outros países 
(SCHRIVER, 1997). Também desde os anos 1970, a psicóloga britânica Patricia Wright constrói pontes entre achados de pesquisas de cunho cognitivo e a formatação de informações verbais e visuais. Ou seja, a integração da Linguagem Simples às práticas de Design da Informação, com abordagem cognitiva, vem sendo construída, consolidada e atualizada ao longo de quatro décadas. Nos últimos anos, por exemplo, bem-sucedidos projetos de simplificação de contratos combinam técnicas de Design da Informação e Linguagem Simples (HAAPIO; BARTON, 2017), inclusive com uso de Inteligência Artificial.

Waller (2011) classifica o Design da Informação como uma “área intrinsecamente multidisciplinar", listando catorze disciplinas ${ }^{2}$ que fornecem embasamento à atividade e categorizando a importância delas na formação profissional. A escrita com clareza é considerada por Waller um conhecimento crítico na formação de designers. Já Baer (2009) elencou oito disciplinas ${ }^{3}$ afins ao Design da Informação, entre elas a Linguagem Simples. Segundo a autora, "como defensores da organização clara e do desenho da informação, especialistas em Linguagem Simples são excelentes colaboradores para projetos de Design da Informação"4.

Porém, mesmo com um vasto histórico de integração e uma evidente aplicabilidade, ainda são necessários esforços para justificar projetos que integrem palavra e imagem. Schriver (1997, p.xxv) afirma que "o profissional de hoje deve ser flexível o suficiente para cruzar a divisão disciplinar entre redação e design""5.

Nesta pesquisa, buscou-se esta aproximação. Assim sendo, além de aportes téoricos na área de Ergonomia e Design da Informação, buscamos subsídios na área da Psicolinguística, que se ocupa de questões linguísticas a partir de uma abordagem cognitiva, com foco nos processos de produção e de compreensão da

\footnotetext{
${ }^{2}$ As catorze disciplinas citadas por Waller (2011) são: Projeto gráfico; Escrita com clareza/Retórica; Projeto de interface/Interação Humano-Computador; Tecnologia da Informação; História do Design; Marketing; Pesquisa de mercado; Psicologia cognitiva; Psicologia aplicada; Jornalismo; Ciência/administração da informação; Psicologia da percepção; Sociolinguística; Linguística textual.

${ }^{3}$ As oito disciplinas citadas por Baer (2009) são: Design Gráfico, Arquitetura da Informação, Design de Interação, UX, Usabilidade, Ergonomia/Fatores Humanos, Interação Humano-Computador e Linguagem Simples.

${ }^{4}$ Original em inglês: As proponents of clear organization and design of information, plain language experts make excellent collaborators for information design projects. Neste sentido, é curioso notar que Rob Waller, um expoente do Design da Informação, é casado com uma redatora especialista em Linguagem Simples, Jenny Waller.

${ }^{5}$ Original em inglês: Today's professional must be flexible enough to cross the disciplinary divide between writing and design.
} 
linguagem. A Psicolinguística investiga aspectos que podem representar custo ao processamento em diferentes tipos de texto.

Ao colocar em diálogo Design e Psicolinguística sob a perspectiva da compreensibilidade textual, a presente pesquisa espera contribuir para futuros estudos na Ergonomia e no Design da Informação que desdobrem aspectos aqui levantados. Acredita-se que achados desta investigação têm potencial para cooperar com o corpo de conhecimento científico da redação em Linguagem Simples, gerando evidências que também colaborem para estudos em outros campos do saber interessados na compreensibilidade da informação. Entre esses campos, incluem-se Administração Pública, Ciência da Informação, Computação, Comunicação, Design de Documentos, Design Social, Direito, Educação, Economia Comportamental, Estudos da Linguagem, Gestão de Políticas Públicas, Redação Técnica, Saúde, Usabilidade e UX Writing, além de estudos no campo da Justiça Social.

Do ponto de vista pessoal, os impactos que textos em burocratês causam à vida cívica digital mobilizam o interesse da pesquisadora desde 2016. O intuito de tornar essa discussão mais visível levou-a a cursar especialização em Ciências Sociais/ Cultura do Consumo na PUC-Rio e publicar o trabalho de conclusão de curso no formato de livro (Clareza em textos de e-gov, uma questão de cidadania). O presente estudo aprofunda e expande aquele estudo inicial, ampliando a visibilidade do debate.

\section{7.}

\section{Estrutura da dissertação}

O capítulo 2 apresenta a fundamentação sobre compreensibilidade textual, articulando conceitos de Ergonomia, Design da Informação e Psicolinguística.

O capítulo 3 examina o estilo de escrita típico do setor público: são apresentadas as principais características linguísticas do "burocratês". Discute-se a habilidade de leitura da população brasileira e relacionam-se leis e programas federais que determinam clareza nas informações públicas.

O capítulo 4 reúne informações sobre o movimento social e a técnica de comunicação Linguagem Simples, na perspectiva do setor público. Traça uma 
cronologia com marcos do movimento internacional. Discute aspectos da técnica, exemplifica diretrizes e lista críticas frequentes. Relata como entes públicos brasileiros recomendam o uso de Linguagem Simples.

O capítulo 5 examina o papel do texto fácil de entender na prestação de serviços digitais. Discute vantagens, barreiras e habilidades inerentes à governança digital. Traz informações sobre a digitalização da administração federal brasileira e sobre o atendimento digital do Instituto Nacional de Seguro Social (INSS). Indica os países em que a Linguagem Simples é usada em portais nacionais de serviço.

O capítulo 6 registra como foi feito o levantamento documental de diretrizes de Linguagem Simples recomendadas por governos para uso em serviços digitais. São apresentados os critérios de categorização das diretrizes e os quadros temáticos resultantes, além das 12 diretrizes mais recorrentes.

O capítulo 7 relata o estudo experimental para aferir a compreensibilidade de informações sobre o benefício do Auxílio-doença do INSS. São apresentados projeto do experimento, perfil de participantes, materiais utilizados, procedimentos de coleta e tratamento dos dados. São apresentadas estatísticas descritivas, análise inferencial das variáveis dependentes e os dados qualitativos coletados no experimento.

Além de fazer uma análise geral da pesquisa, o capítulo 8 sintetiza e integra a argumentação conceitual às evidências que foram geradas pela pesquisa. 


\section{Compreensibilidade textual}

Este capítulo apresenta a fundamentação sobre compreensibilidade textual que orientou a pesquisa. Os pontos desenvolvidos nos capítulos seguintes - em torno da compreensibilidade de textos em governo eletrônico - consideram os conceitos aqui expostos.

O termo compreensibilidade costuma ser usado de forma intercambiável com leiturabilidade, inteligibilidade ou mesmo legibilidade. O capítulo começará apresentando os termos originais em inglês e as escolhas de tradução que foram feitas. A seguir, serão apresentadas as definições de cada termo e as diferenças que existem entre eles.

Depois, apresentará constructos da Ergonomia, do Design da Informação e da Psicolinguística. Após uma descrição sucinta de cada disciplina, serão discutidos conceitos sobre compreensibilidade textual e processamento da informação na perspectiva de autores referenciais. Também serão apresentados aspectos que prejudicam e facilitam compreender textos conforme a perspectiva desses autores.

O capítulo termina com uma síntese dos argumentos apresentados.

\section{1.}

\section{Compreensibilidade, leiturabilidade, inteligibilidade e legibilidade}

Compreensibilidade, leiturabilidade, inteligibilidade e legibilidade são palavras que remetem ao mesmo campo semântico. Tanta semelhança explica que ocorra uma sobreposição de significados. Isso ocorre em português e em inglês, idioma no qual grande parte da bibliografia de referência em compreensibilidade é publicada. Na língua inglesa, os termos também se parecem e são constantemente 
usados de forma intercambiável: comprehensibility, readability, inteligibility e legibility.

\subsection{1}

\section{Termos em inglês e escolhas de tradução}

O termo mais recorrente nos dias atuais em língua inglesa é readability, como demonstra a pesquisa realizada no mecanismo de busca Google Ngram Viewer ${ }^{6}$ em fevereiro de 2021, reproduzida na Figura 2. Na segunda posição, bem abaixo, vem o termo legibility ${ }^{7}$, seguido de comprehensibility e inteligibility.

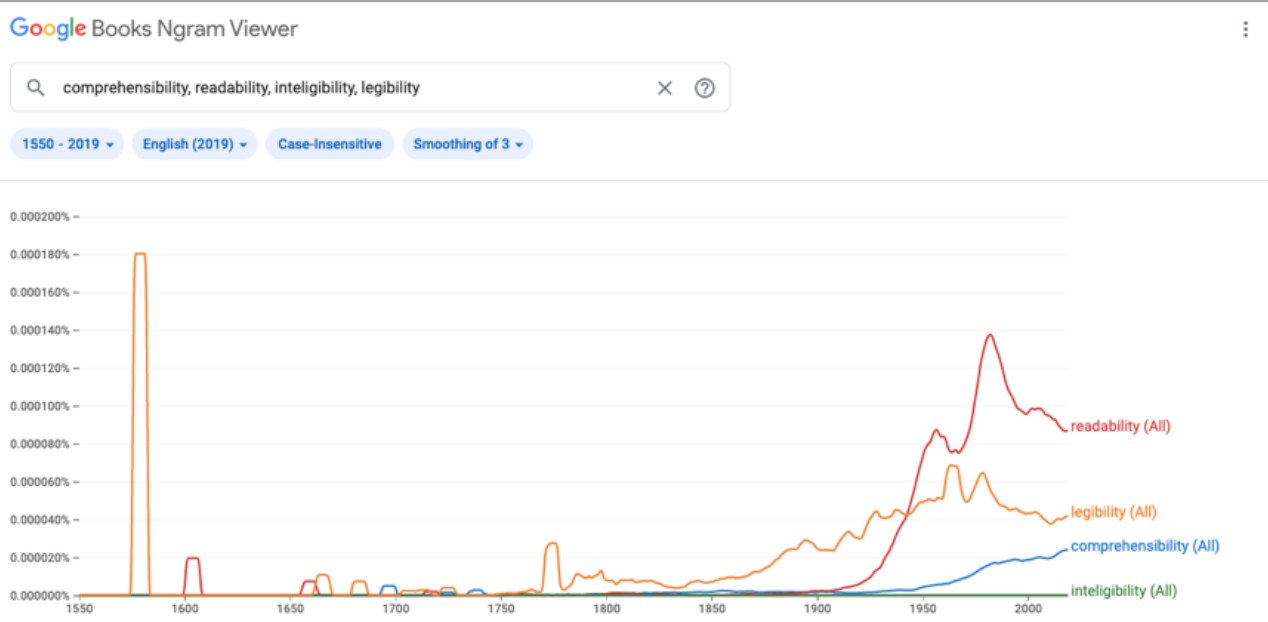

Figura 2: Frequência dos termos readability, legibility, comprehensibility e inteligibility em fontes impressas nos corpora de texto do Google em inglês de 1550 até 2019. Fonte: Google NGram Viewer.

\footnotetext{
${ }^{6} \mathrm{O}$ Google Ngram Viewer exibe palavras ou frases selecionadas pelo usuário (ngrams) em um gráfico que mostra como essas palavras ou frases estão presentes em um corpus. O corpus do Google Ngram Viewer é composto pelos livros digitalizados disponíveis no Google Books. É possível fazer buscas entre os anos 1500 e 2019. O eixo X mostra o ano em que os trabalhos do corpus foram publicados. O eixo Y mostra a freqüência com que os ngramas aparecem ao longo do corpus. Os usuários introduzem os ngramas e depois podem selecionar se ajustes de caixa (alta/baixa), intervalo de datas, idioma do corpus e suavização das linhas no gráfico.

${ }^{7}$ Vale observar que o adjetivo legible é usado desde o século 15, conforme registra o dicionário Merriam-Webster (Disponível em: https://www.merriam-webster.com/dictionary/legible. Acesso em: 16 mar. 2021).
} 
Dada a alta circulação do termo readability, é válido conhecer o significado a ele atribuído em dicionários, antes de apresentar a definição pela qual a pesquisa optou.

A lexicografia em inglês atribui variadas acepções à palavra, que é dicionarizada dentro do verbete readable e costuma ser associada à palavra legible. Ou seja, readability e legibility são considerados sinônimos em alguns dicionários.

No Oxford Advanced Learner's Dictionary, a primeira acepção de readable é "que pode ser lido com facilidade ou de forma agradável" / that can be read easily or enjoyably; e a segunda acepção é "legível" / legible. (OXFORD, 1989). O Webster's New World Dictionary define readable como "interessante ou de fácil leitura"/ interesting or easy to read, oferecendo para readability o sinônimo “facilidade de leitura”/ readableness (WEBSTER'S, 1988). Já no dicionário online American Heritage Dictionary of the English Language, a primeira acepção de readable é "de fácil leitura, legível"/ easily read, legible; a segunda acepção é "agradável ou interessante de ler"/pleasurable or interesting to read (AMERICAN, 2016).

Vale também registrar as interrelações entre os quatro termos em inglês. No tesauro WordNet 3.0 da Universidade de Princeton $^{8}$, readability é considerado um sinônimo de legibility, e tem relação com inteligibility, comprehensibility e outros termos (READABILITY, s/d). A Figura 3 mostra a representação visual da relação entre as palavras.

\footnotetext{
${ }^{8}$ WordNet é um banco de dados lexical em inglês. Substantivos, verbos, adjetivos e advérbios são agrupados em conjuntos de sinônimos cognitivos (synsets), cada qual expressando um conceito distinto. Os sinônimos interligam-se por meio de relações conceituais-semânticas e lexicais. A rede resultante de palavras e conceitos relacionados entre si pode ser acessada com o browser. $\mathrm{O}$ WordNet é gratuito e está disponível para download. É usado na Lingüística Computacional e no Processamento de Linguagem Natural. Disponível em: https://wordnet.princeton.edu. Acesso em: 16 mar. 2021.
} 


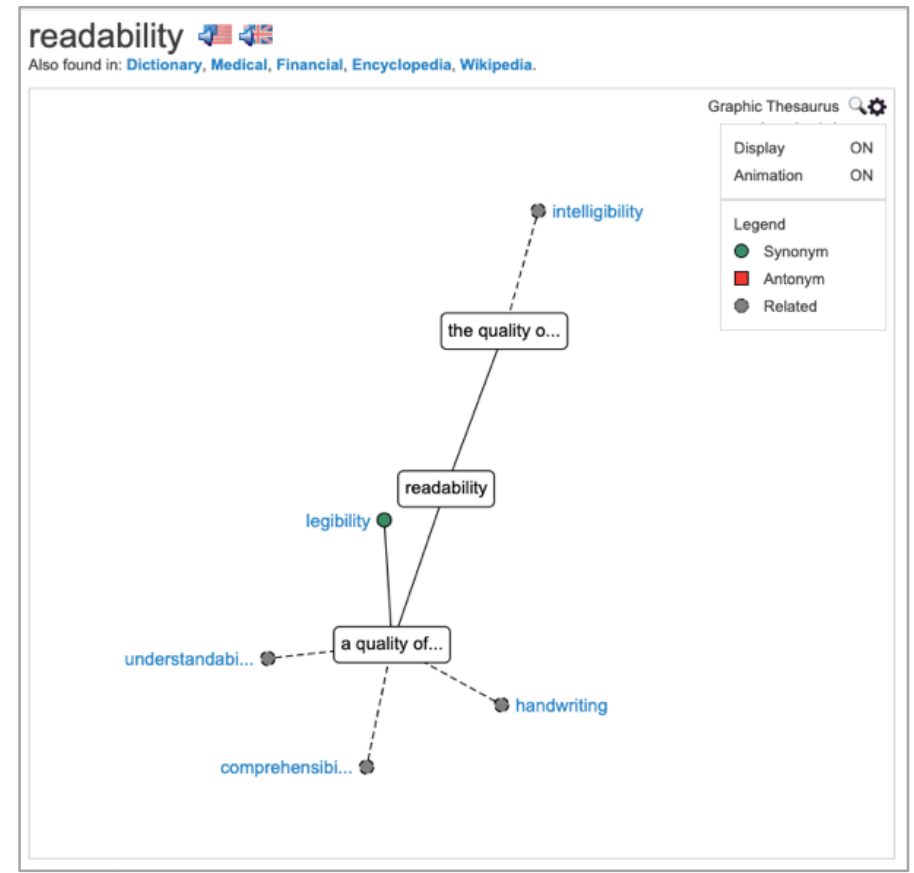

Figura 3: Representação da relação semântica entre os termos readability, comprehensibility, inteligibility e legibility. Fonte: Tesauro gráfico WordNet 3.0, da Universidade de Princeton

A presente pesquisa fez escolhas de tradução ancoradas na bibliografia consultada. Considerou o termo compreensibilidade como tradução de comprehensibility. Conforme será apontado na definição a seguir, esta palavra cobre um escopo mais amplo dos que as demais.

Os termos readability e inteligibility foram considerados como sinônimos, sendo traduzidos para o português como leiturabilidade e inteligibilidade.

O termo legibilidade foi considerado como tradução de legibility, sendo usado para se referir especificamente a elementos visuais do texto.

\subsection{2}

\section{Definição de termos}

Compreensibilidade (comprehensibility) - Definição proposta por Thomas M. Duffy, professor do programa de ciências cognitivas e tecnologia de sistemas instrucionais da Universidade de Indiana, e diretor do Center for Research on Learning and Technology. A carreira de Duffy é dedicada a explorar o design e o uso da informação na educação e em ambientes de trabalho. 
A compreensibilidade é o único fator de usabilidade inseparável da interação do leitor com o texto. A compreensibilidade de qualquer texto varia em função de capacidade de leitura, capacidade de interpretação gráfica e conhecimento técnico do leitor, além de variáveis situacionais transitórias. Em condições ideais, o julgamento sobre um texto ser ou não compreensível dependeria, então, de testar uma amostra de leitores fazendo várias tarefas usando o texto. ${ }^{9}$ (DUFFY, 1985)

Leiturabilidade ou inteligibilidade (readability) - Definição proposta por William Dubay, especialista em leiturabilidade e consultor de Linguagem Simples, autor do estudo The Principles of Readability.

"A leiturabilidade é o que torna alguns textos mais fáceis de ler do que outros. É frequentemente confundida com a legibilidade, que diz respeito ao tipo de letra e layout." (DUBAY, 2004).

Legibilidade (legibility) - Definição proposta por Rob Waller, diretor do Simplification Center. O centro surgiu dentro do Departamento de Tipografia e Comunicação Gráfica da Universidade de Reading, na Inglaterra, tornando-se depois uma organização independente. Waller é o atual presidente do International Institute for Information Design.

\begin{abstract}
"Legibilidade incorpora tanto o uso de fontes legíveis quanto atributos de layout (tais como alinhamento do texto e adoção de uma coluna apropriada medida para o tamanho do texto) para melhorar a facilidade de leitura" (Waller 2011, apud BLACK ET AL., 2017)
\end{abstract}

2.2.

\title{
Compreensibilidade textual na perspectiva da Ergonomia
}

A Ergonomia foi constituída na Inglaterra em 1949. Surgiu da necessidade de adequar equipamentos, ambientes e tarefas às características físicas, cognitivas e psíquicas das pessoas. Apesar da etimologia vinculada ao ambiente de trabalho ${ }^{10}$,

\footnotetext{
${ }^{9}$ Original em inglês: Comprehensibility is the only usability factor that is inextricably tied to the interaction of the reader with the text. The comprehensibility of any particular text will vary as a function of the reading skill, the graphic interpretive skill, and the technical knowledge of the reader, as well as with a variety of transient situational variables. Ideally the judgment of whether or not a text is comprehensible would therefore depend on a reader test, that is, the ability of a sample of readers to do a variety of job tasks using the text.

${ }^{10}$ A palavra Ergonomia deriva do grego ergon (trabalho) e nomos (normas, regras, leis).
} 
aplica-se a qualquer atividade que envolva algum grau de experiência ou esforço dos indivíduos (MORAES E MONT'ALVÃO, 2010, p.15). É uma disciplina centrada nas capacidades e limites dos seres humanos - não à toa, também é conhecida pelo termo Human Factors (Fatores Humanos). Prega que todo sistema deve se adequar às necessidades de quem o utiliza, visando o bem-estar da pessoa e o desempenho da tarefa com eficiência e segurança. Moraes (2002, p.45) aponta que "é a pessoa que controla o sistema (...), que dirige o seu curso (...), que pode mudar o sistema".

A Associação Internacional de Ergonomia assim define o campo de saber:

\begin{abstract}
A Ergonomia (ou Fatores Humanos) é uma disciplina científica relacionada ao entendimento das interações entre os seres humanos e outros elementos ou sistemas, e à aplicação de teorias, princípios, dados e métodos a projetos, a fim de otimizar o bem estar humano e o desempenho global do sistema. (...) Trata-se de uma disciplina orientada para uma abordagem sistêmica de todos os aspectos da atividade humana. (...) Como ciência, trata de desenvolver conhecimentos sobre as capacidades, limites e outras características do desempenho humano e que se relacionam com o projeto de interfaces, entre indivíduos e outros componentes do sistema. (MORAES E MONT’ALVÃO, 2010, p.18-20)
\end{abstract}

Um dos objetivos da abordagem sistêmica da Ergonomia é reduzir a carga cognitiva para otimizar o desempenho de tarefas. São de especial interesse questões relacionadas à atenção, processamento de informações e tomada de decisão, incluindo a compreensão de textos. Conforme Moraes (2002, p. 28), a Ergonomia sempre tratou das comunicações e interações com o objetivo de "facilitar o entendimento mútuo".

Entre os domínios de especialização da disciplina, consta a Ergonomia Cognitiva, que estuda carga de trabalho, tomada de decisão e stress, entre outros processos mentais. A área da Ergonomia Informacional atua com um conjunto de parâmetros visando o entendimento de avisos, advertências, manuais de instrução e sistemas de sinalização, também agindo sobre outros sistemas de informação.

\title{
2.2.1.
}

\section{Compreensão como tarefa mental}

Os pioneiros da Ergonomia já consideravam a compreensibilidade textual como um importante campo de estudo. Em Words, words, words, Chapanis (1965) afirmava que a linguagem, uma atividade humana única, deveria ser investigada 
pela disciplina que se chama Fatores Humanos. Chapanis alertava para os inúmeros problemas de compreensibilidade textual em avisos e instruções de equipamentos, especialmente quando decorrentes de frases com estruturas complexas e sequências de substantivos. Ele recomendava aos pesquisadores em Ergonomia que validassem com os usuários as recomendações de linguistas e gramáticos.

Broadbent (1977) foi outro pioneiro a apontar os elementos linguísticos que causavam problemas de compreensão textual na Ergonomia, recomendando: "os ergonomistas devem pensar bem na mensagem que precisam comunicar, antes de definir a estrutura gramatical de frases nas instruções ${ }^{11}$ ".

Bridger (1995) aprofundou-se nos temas de memória, linguagem e compreensão sob a perspectiva ergonômica. A seu ver, a compreensão da linguagem é uma tarefa mental que gera carga de trabalho e, por isso, "os ergonomistas devem procurar projetar material verbal (...) que possa ser compreendido com um mínimo de esforço mental." 12

Problemas de comunicação que interessam à Ergonomia podem ocorrer quando diferentes grupos de pessoas usam palavras diferentes ou usam as mesmas palavras de maneira diferente para falar de um sistema (...) Os designers de equipamentos, manuais e instruções devem entender o vocabulário e as preferências dos vários grupos de pessoas que irão usar os sistemas ${ }^{13}$. (BRIDGER, 1995, p. 397)

\subsection{2.}

\section{Modelo de processamento de Wogalter}

Os modelos de processamento informacional na Ergonomia surgiram a partir de estudos relativos à efetividade de avisos e sinalizações de advertência. Em materiais com este fim, os elementos visuais, tais como pictogramas ou uso de

\footnotetext{
${ }^{11}$ Original em inglês: “...ergonomists (...) think carefully about the message they are trying to communicate, before choosing the grammatical structure of the sentences in the instructions".

12 Original em inglês: "Ergonomists should attempt to design verbal material such as warnings and recovey and emergency procedures wich can be comprehended with a minimal amount of mental effort."

${ }^{13}$ Original em inglês: "Communication problems of interest to Ergonomics can arise when different groups of people use different words or use the same words differently when talking about a system (...) Designers of equipment, manuals, and instructions must understand the vocabulary and preferences of the various groups of people who will use their systems."
} 
cores, têm grande destaque. Textos são considerados "informação verbal" ou "material verbal".

Em 1999, Wogalter concebeu um modelo de processamento informacional que era inicialmente destinado a advertências. O modelo chama-se C-HIP Comunnication-Human Information Processing (Processamento da Informação Humano-Comunicação). Wogalter reviu o modelo em 2006, afirmando que "o processo de análise de processamento da informação poderia ser aplicável a qualquer tipo de informação que se apresenta ao usuário/ consumidor/ trabalhador" (MONT'ALVÃO, 2020).

O modelo de Wogalter considera que uma fonte utilizará um canal para “entregar" uma mensagem. De modo a receber a mensagem, o receptor precisará ter a sua atenção "captada" e mantida. A compreensão recruta memória. O processamento da informação também se baseia em atitudes e crenças do receptor e na sua motivação para assimilar a mensagem transmitida. Levará em conta aspectos demográficos e variáveis pessoais, além de estímulos ambientais, gerando, por fim, um comportamento. Todas as etapas são passíveis de retroalimentação. A Figura 4 reproduz o modelo C-HIP de 2006 traduzido em português, conforme Mont'Alvão (2020).

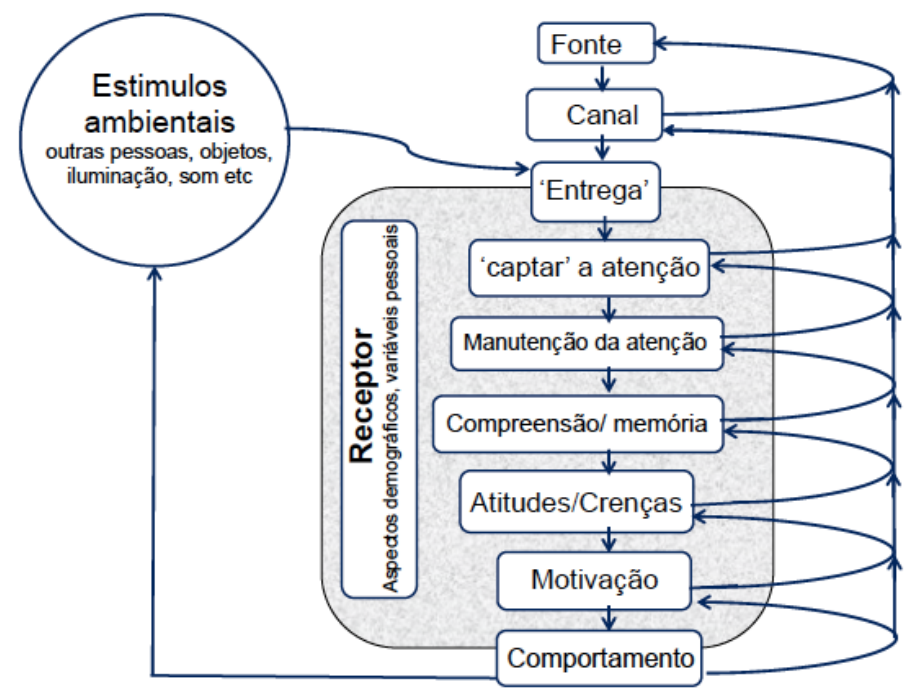

Figura 4: Modelo C-HIP de Wogalter 2006, traduzido para o português (apud MONT’ALVÃO, 2020) 


\subsection{3.}

\section{Ruídos e problemas ergonômicos}

O processamento da informação pode gerar ruídos que causam problemas à comunicação entre pessoas e sistemas. Entre eles, há o ruído semântico, definido por Coelho Neto como "distorção do significado de uma mensagem" (1970, apud MORAES 2002, p. 27). O ruído pode ocorrer tanto na codificação, quando uma intenção é convertida em forma, como na decodificação, quando a mensagem é recebida e recomposta "não com o significado visado pela fonte, mas segundo o significado que interessa, conscientemente ou não, ao destinatário". Entre os ruídos ergonômicos informacionais, interessa a esta pesquisa a dificuldade de perceber e processar informações verbais.

Moraes e Mont'Alvão (2010, p. 131-134) apresentam uma categorização e taxonomia de 22 tipos de problemas ergonômicos que podem afetar sistemas homem-tarefa-máquina. Ao escopo desta pesquisa, interessam os problemas:

Informacionais/Visuais: Deficiências na detecção, discriminação e identificação de informações, em telas, painéis, mostradores e placas de sinalização, resultantes da má visibilidade, legibilidade e compreensibilidade de signos visuais, com prejuízos para a percepção e para a tomada de decisões.

Cognitivos: Dificuldade de decodificação, aprendizagem, memorização em face de inconsistências lógicas e de navegação dos subsistemas comunicacionais e dialogais resultam perturbações para a seleção de informações, para as estratégias cognoscitivas, para a resolução de problemas e para a tomada de decisões.

Instrucionais: Desconsideração das atividades concretas da tarefa durante o treinamento; Manuais de instrução confusos que privilegiam a lógica de funcionamento em detrimento das estratégias de utilização.

A partir da taxonomia, Moraes e Mont'Alvão (2010, p. 131-134) propõem parâmetros para orientar a ação ergonomizadora. Entre eles, há parâmetros informacionais (compreensibilidade e quantidade de informação; priorização e ordenação) e cognitivos (compreensibilidade e compatibilização de repertórios; processamento de informações, coerência das instruções e das ações envolvidas na tarefa; compatibilidade entre a quantidade de informações e a compatibilidade da tarefa). 


\subsection{4.}

\section{Aspectos do texto fácil de entender}

O estudo de Bridger (1995, p. 398 e 401) integrou evidências científicas que apontam a necessidade de projetar materiais verbais de fácil compreensão. Seu estudo baseou-se nas investigações de linguagem como processo cognitivo de Judith Greene e em trabalhos de psicologia cognitiva de Roy Lachman, Darlene Howard e Paul Barber - todos trabalhos realizados nos anos 1980-1990. Deste modo, Bridger compôs um check-list para avaliar níveis de conhecimento na compreensão da linguagem - som e ortografia das palavras, significados comuns das palavras, regras gramaticais, usos metafóricos-idiomáticos, conhecimento contextual e conhecimento de mundo - e compreensão de relações sintáticas de sentenças. $\mathrm{O}$ autor sintetizou em três diretrizes o que faria uma sentença ser facilmente compreendida:

Ter poucas orações: Uma sentença complexa pode causar dificuldades de compreensão ao exigir do leitor uma carga excessiva de memória de curto prazo. Usar voz ativa em vez de passiva: A voz passiva geralmente impõe uma carga de compreensão ao leitor. Ser afirmativa e não negativa: Sob estresse ou alta carga de trabalho na tarefa primária, a compreensão pode falhar. ${ }^{14}$ (BRIDGER, 1995, p. 405406).

Bridger destaca ainda o papel de palavras concretas e abstratas, observando ser mais fácil lidar com uma sintaxe complexa quando o assunto é concreto ou as palavras são concretas. Deve-se evitar palavras abstratas desnecessárias. Por fim, o autor aponta que a linguagem de fácil compreensão exige cuidado ao pressupor o que é senso comum para o leitor: "se tais suposições forem inválidas, pode haver problemas de compreensão e mal entendidos." ${ }^{15}$ (BRIDGER, 1995, p. 402)

\footnotetext{
${ }^{14}$ Original em inglês: They contain few clauses: A complex sentence may cause comprehension difificulties by placing an excessive short-term memory load on the reader. They utilize active rather than passive voice: The passive voice usually places a comprehension load on the reader. They are affirmative rather than negative: Under stress or high primary-task workload, comprehension may breakdown.

${ }^{15}$ Original em inglês: If these assumptions are invalid, comprehension problems and misunderstandigs may result.
} 


\section{3.}

\section{Compreensibilidade textual na perspectiva do Design da Informação}

Pettersson (2012, p. 24-26) considera que a Ciência do Design, como campo de pesquisa acadêmica, educação e treinamento, abrange seis famílias ${ }^{16}$, sendo uma delas o Design de Mensagens. Na perspectiva do autor, a família Design de Mensagens é permeada por mais de cinquenta disciplinas - entre elas, a Linguística e as ciências cognitivas - e possui cinco gêneros ${ }^{17}$, entre eles o Design da Informação.

O principal objetivo do Design da Informação é a clareza na comunicação: para tal, leva em conta as necessidades do público-alvo e as tarefas a serem executadas. Abrange as etapas de análise, planejamento, apresentação e compreensão das mensagens. Todas as mensagens devem ser concebidas, produzidas e distribuídas com precisão para que, depois, sejam interpretadas e compreendidas corretamente pela maioria dos membros do público-alvo. Enquanto linguistas diferenciam a linguagem falada da escrita, os designers estabelecem distinção entre linguagem verbal e linguagem pictórica, sendo que a linguagem verbal compreende as categorias falada, escrita e tátil (PETTERSSON, 2012, p.30).

Na perspectiva de Frascara (2004), o Design da Informação envolve organização da informação (conteúdo) e apresentação visual (forma). O designer que atua neste campo deve ter sensibilidade para forma e conteúdo: o seu trabalho consiste na eficácia, adequação, beleza e economia das mensagens. Frascara destaca a importância que o texto ocupa nas peças de comunicação:

Há quem pense que não compete aos designers se preocuparem com textos. Entretanto, se somos responsáveis pelo sucesso daquilo que projetamos, devemos ser capazes de assessorar clientes e equipes de produção quanto à eficácia comunicacional do material escrito. Devemos fazer isso mesmo se não formos capazes de escrever ou editar. ${ }^{18}$ (FRASCARA, 2004, p. 175)

\footnotetext{
${ }^{16}$ As seis famílias são: Design de Artefatos, Design de Mensagens, Design de Desempenho, Design de Sistemas, Design de Ambientes e Filosofia do Design.

${ }^{17}$ Os cinco gêneros são: Design Gráfico, Design da Informação, Design Instrucional, Design de Massa e Design de Persuasão.

18 Original em inglês: Some people might think that it is not up to the designers to concern themselves with texts. However, since we are responsible for the communicational success of the things we design, we should be able to advise clients and production teams in connection with the communicational effectiveness of written material. We should do this even if we are not able to write or edit .
} 
Petterson (2012, p. 38-40) tem visão similar. Para ele, designers devem ter habilidade para escrever textos compreensíveis, simples e consistentes. Mas também precisam criar imagens, tipografia e layout claros. A tarefa é pesada para uma pessoa só, daí ser necessário uma equipe com habilidades em diferentes áreas trabalhando em conjunto. $\mathrm{O}$ autor adverte que o designer da informação não deve considerar a comunicação concluída até que o público-alvo consiga compreender as mensagens. Petterson (2015, p. 128) assevera que, no Design da Informação, a escrita sempre cumpre um papel funcional.

\subsection{1.}

\section{Informação, memória e entendimento}

O entendimento do usuário e a compreensibilidade da mensagem são fatores basilares no Design em geral e no Design da Informação em particular. Pettersson (2012, p. 158-159) aponta existir uma estreita relação da clareza e da simplicidade de uma informação com a facilidade e a eficácia de percepção, processamento mental e memória.

Pettersson $(2015$, p.41) observa que, como toda atividade mental, a leitura de textos e imagens recruta a memória de curto prazo, que tem capacidade limitada. "Se as funções das palavras no texto não forem percebidas imediatamente, a memória de curto prazo fica sobrecarregada com longas cadeias de palavras que não conseguem ser postas em um contexto significativo." 19 A compreensão é um processo no qual os leitores integram o texto às suas próprias experiências. $\mathrm{O}$ autor considera existir ainda uma etapa de "pré-entendimento", na qual a forma gráfica de um texto cria expectativas em relação ao seu conteúdo.

Espera-se que certos tipos de documentos tenham um determinado aspecto; por outro lado, quando vemos um documento de determinada espécie, esperamos que um certo tipo de texto e imagens o acompanhe. Assim, em função destas expectativas, ativamos os processos cognitivos necessários para interpretar a mensagem. O leitor desenvolve seus próprios métodos para prever o que será um texto. As introduções, resumos, tabelas de conteúdo, resumos, ilustrações e tabelas têm todas funções importantes a serem preenchidas. ${ }^{20}$ (PETTERSSON, 2015, p. 41)

\footnotetext{
${ }^{19}$ Original em inglês: If the functions of the individual words in a text are not immediately apparent to us, our short-term memory becomes overloaded with long chains of words that cannot be directly put into a meaningful context.

${ }^{20}$ Original em inglês: We expect certain types of documents to look a particular way; contrarily, when we see a document of a certain type we expect a particular type of text and pictures to
} 


\subsection{3.}

\section{Aspectos que prejudicam a leitura}

Kathryn Campbell alerta que complexidade gera "ruído cognitivo", impedindo que o usuário se exponha à informação essencial (BAER, 2009, p.78).

Pettersson (2015) elenca aspectos que afetam a compreensibilidade dos textos: escolha de palavras (familiaridade, extensão, grau de abstração, número de sílabas), construção de frases (extensão), divisão de parágrafos, aspectos visuais (títulos e subtítulos, extensão da linha, entrelinhas, ilustrações, tamanho das letras), relevância do texto para o leitor e tamanho da página. O autor pontua que aspectos de estilo textual podem causar problemas na leitura;

Um estilo de escrita que inclui palavras abstratas, siglas, frases longas e complexas, linguagem pomposa, jargão e construções passivas pode obstruir a leitura do texto. Frases longas e complexas requerem mais capacidade cognitiva de processamento do que frases curtas e simples. A leitura de um texto difícil demora tempo. É preciso decodificar palavras, e manter novos conceitos na memória de trabalho. (Petros et al. 1990, apud PETTERSSON, 2015, p. 75) ${ }^{21}$

Uso de linguagem especializada e jargão geram o risco de uma "comunicação unidirecional", sem valor fora dos círculos iniciados. Tal estilo textual alija o leitor que não domina os códigos, podendo levá-lo a um estado de espírito defensivo e intransigente. (PETTERSSON, 2015, p. 88).

\footnotetext{
Textos complicados geralmente são defendidos com base no fato de que seu assunto é complicado. No entanto, na realidade, quanto mais difícil for o assunto, mais se deve tentar expressá-lo de forma compreensível. É certamente mais razoável esperar que uma pessoa ponha esforço na escrita de seu texto, do que os vários destinatários sejam obrigados, cada um por si, a gastar esforço para interpretá-lo. ${ }^{22}$ (LILJESTRAND e ARWIDSSON 1979, apud PETTERSSON 2015)
}

accompany it. Thus, it is in the light of these expectations that we activate the cognitive processes needed to interpret the message. The reader develops his own methods for predicting what a text wil be about. Introductions, abstracts, tables of contents, summaries, illustrations and tables all have important functions to fill.

${ }^{21}$ Original em inglês: A writing style that includes abstract words, acronym,s long and complex sentences, jargon, and passive constructions obstruct the reading of the text. Long and complex sentences require more cognitive capacity to process than short and simple sentences. It takes time to read a difficult test. We have to decode words, and maintain new concepts in working memory.

${ }^{22}$ Original em inglês: Complicated texts are often defended on the grounds that their subject matter is complicated.In reality, however, the more difficult the subject is the more one must attempt to express it in comprehensible way. It is surely more reasonable to expect that someone who is writing 


\subsection{4.}

\section{Características da informação fácil de entender}

Designers da informação devem garantir clareza de texto e imagens para manter a atenção dos leitores. Pettersson (2012,p. 103-104) lembra que as pessoas evitam materiais lhes parecem difíceis e pomposos. Desta forma, ele indica usar palavras curtas, afirmativas, declarativas, concretas; evitar jargão; usar frases simples, curtas, precisas e na voz ativa; usar parágrafos curtos; dividir o texto em blocos, indicando as mudanças de tema por meio de espaços em branco e ênfase tipográfica. $\mathrm{O}$ autor também recomenda fazer um check-list geral de linguagem, estilo e terminologia antes de considerar a mensagem pronta. Para facilitar a percepção do texto, é recomendável criar "pré-entendimento" - por exemplo, fornecer uma lista dos conteúdos - e evitar informação irrelevante.

Pettersson (2012, p. 159-160) recomenda projetar as mensagens de modo a facilitar o processamento mental: "ler um texto é uma atividade estruturada que requer várias fixações do olhar em cada linha (...) a identificação das palavras é um processo que se dá em múltiplos estágios, requer tempo". ${ }^{23} \mathrm{O}$ texto deve ser conciso, consistente e preciso. Daí ser necessário fornecer vários exemplos de uso e não-uso; prever o tempo necessário para leitores lerem, interpretarem e entenderem a mensagem; evitar grandes massas de texto, dividindo as informações em seções, subseções e parágrafos; usar títulos em diversos níveis hierárquicos de modo a ajudar os leitores a organizarem a informação cognitivamente para melhor retenção e posterior recuperação.

\section{4.}

\section{Compreensibilidade textual na perspectiva da Psicolinguística}

\footnotetext{
for several people expend effort on the writing of his text, than that the various receivers be obliged, each on his own to expend effort interpreting it!

${ }^{23}$ Original em inglês: Reading a text is a very structured activity with several eye fixations on each line (...) word identification is a multi-stage process, which will take some time.
} 
A Psicolinguística é uma subárea da Linguística, vinculada às chamadas Ciências Cognitivas. A constituição da área como hoje a entendemos remete ao momento da chamada Revolução Cognitiva, nos anos 1950.

Psicolinguística é a disciplina que investiga e descreve os processos psicológicos que tornam possível ao ser humano dominar e usar a linguagem. Os psicolinguistas conduzem pesquisas sobre o desenvolvimento da fala e da linguagem e como as pessoas de todas as idades compreendem e produzem a linguagem ${ }^{24}$. (RATNER e GLEASON, 2004)

A Psicolinguística ocupa-se dos processos e operações mentais envolvidos no uso da linguagem, na produção e compreensão da língua falada e escrita. Deste modo, é uma disciplina afim à Psicologia Cognitiva. Uma das suas áreas de pesquisa volta-se para a investigação da compreensão leitora e as habilidades necessárias para compreender textos. Considera a perspectiva de compreensão multimodal, que integra informação linguística e visual durante a leitura. Também investiga as demandas cognitivas associadas ao processo de escritura e avalia estratégias de intervenção na produção textual. Deste modo, está relacionada aos estudos da informação.

O americano Charles Perfetti, professor e pesquisador da Universidade de Pittsburg, é um dos psicolinguistas de referência no campo da compreensão leitora. A seguir, serão articulados conceitos que constam de trabalhos por ele publicados em 1999, 2001 e 2005, este último em co-autoria com Landi e Oakhill.

\subsection{1.}

\section{Compreensão como processo cognitivo}

Para Perfetti (1999, p. 170), a compreensão de uma mensagem depende, em grande parte, de dois grandes componentes: “(i) a identificação das palavras e (ii) o envolvimento de mecanismos de processamento de linguagem que montam as palavras nas mensagens" 25 . Além da identificação das palavras, os processos

\footnotetext{
${ }^{24}$ Original em inglês: Psycholinguistics is the discipline that investigates and describes the psychological processes that make it possible for humans to master and use language. Psycholinguists conduct research on speech development and language development and how individuals of all ages comprehend and produce language.

${ }^{25}$ Original em inglês: (i) the identification of words; (ii) the engagement of language processing mechanisms that assemble these words into messages.
} 
incluem a montagem das palavras conforme a estrutura sintática das frases (processo conhecido pelo termo em inglês parsing), a integração do material lido com o restante do texto e as inferências que os leitores devem a fazer a partir do que leram. Ou seja, o entendimento do que se lê é resultado de diferentes processos cognitivos não só linguísticos, mas também decorrentes de outras fontes de conhecimento. Esses processos ocorrem de forma incremental. O modelo mental do texto resulta das várias etapas de processamento.

Entre os diversos recursos cognitivos que a leitura bem-sucedida requer, um dos principais é a memória de trabalho.

\begin{abstract}
Compreender uma frase envolve lembrar palavras contidas na frase, recuperar informações precedentes, analisar a estrutura da frase e outros processos que requerem recursos. A memória de trabalho - um ou mais sistemas de capacidade limitada que tanto armazenam como manipulam informações - é um gargalo para estes processos. (...) Evidências mostram que o importante na habilidade de compreensão leitora é um sistema de memória de trabalho ativo e não um armazenamento passivo de memória de curto $\operatorname{prazo}^{26}$. (PERFETTI, LANDI E OAKHILL, 2005, p. 238)
\end{abstract}

\title{
2.4.2.
}

\section{Processamento lexical, sintático e textual}

O processamento linguístico na compreensão de textos escritos ocorre em vários níveis, nas diversas unidades da linguagem. A primeira unidade é a palavra (processamento lexical). Mais de $80 \%$ das palavras de conteúdo são fixadas quando se lê um texto com o objetivo de entendê-lo (CARPENTER E JUST 1983, apud PERFETTI 1999). O tamanho da palavra influencia a probabilidade de ela ser lida.

Compreender uma palavra requer a convergência de aspectos ortográficos e fonológicos, de modo a acessar uma representação mental. $\mathrm{O}$ acesso pode se dar por duas rotas: endereçada (addressed) e montada (assembled). Perfetti (1999, p.173) explica que "a rota endereçada é a consulta direta de um endereço; a rota

\footnotetext{
${ }^{26}$ Original em inglês: Understanding a sentence involves remembering words within the sentence, retrieving information from preceding text, parsing the sentence, an other processes that require resources. Working memory - one or more systems of limited capacity that both store and manipulate information-is a bottleneck for these processes. (...) In addition, the evidence shows it is an active working memory system rather than a passive short-term memory store that is important in reading comprehension skill.
} 
montada é a montagem da fonologia da palavra como uma etapa intermediária no processo" 27 . Isto é, ou o leitor acessa diretamente o seu léxico mental para identificar a palavra, ou então requer uma etapa adicional para reconhecer o conjunto de letras que tem diante de si. Vale observar que a compreensão da palavra embute uma tarefa de decisão lexical: o leitor deve atribuir o significado cabível à palavra no contexto.

A leitura bem-sucedida de uma palavra ocorre quando as letras correspondem a uma representação mental (PERFETTI, 2001, p. 12800). Conhecer o significado das palavras é central para a compreensão de textos.

\begin{abstract}
A habilidade no nível da palavra pode ser considerada um reflexo da qualidade lexical, do conhecimento das formas e dos significados das palavras, o que resulta em um processamento eficaz e eficiente. Quando se trata de compreensão, o processamento no nível das palavras nunca conta a história completa. Entretanto, é uma referência para avaliar o papel dos processos de nível superior, tais como o monitoramento da compreensão e a elaboração de inferências. (PERFETTI, LANDI E OAKHILL, 2005, p. 242)
\end{abstract}

Outra etapa do processo de compreensão ocorre no nível da sentença (processamento sintático). Ao fazer a computação sintática dos elementos da frase, o leitor precisa tomar decisões à medida em que monta as frases na cabeça. $\mathrm{O}$ processamento sintático ocupa os primeiros estágios da compreensão e ocorre de forma automática, não consciente (PERFETTI, LANDI E OAKHILL, 2005, p. 185). Aqui, a memória de trabalho também tem um papel determinante. Perfetti (1999, p. 184) aponta que "leitores com muita capacidade de memória de trabalho podem considerar mais de uma possibilidade de parsing, deixando para escolher a adequada após ler outras informações da frase" 28 .

Além compreender palavras e frases avulsas, "o leitor deve combinar a mensagem de cada frase com a mensagem acumulada até aquele ponto, com base no texto que já leu" 29 (PERFETTI, 1999, p. 186). O processamento no nível do texto implica em integrar as informações à medida em que são lidas. Há ainda as informações fora do texto que são necessárias para compreender o que está sendo

\footnotetext{
${ }^{27}$ Original em inglês: The addressed route is the direct look-up of an address; the assembled route is the assembly of the word's phonology as an intermediate step in the process.

${ }^{28}$ Original em inglês: Readers with large (working-memory) capacities can keep more than one parsing possibility in mind and then choose the needed one when later sentence information is read. ${ }^{29}$ Original em inglês: The reader must combine the message of each sentence with the message accumulated up to that point on the basis of the prior text.
} 
dito. Para que o leitor alcance uma realidade a partir do texto, geralmente precisa fazer inferências, pois nem todas as informações estão ali explícitas. (PERFETTI, 1999, p. 188.)

\title{
2.4.3.
}

\section{Modelo de processamento e possíveis fontes de problemas de compreensão}

Perfetti (1999) propôs um modelo com os componentes envolvidos no processamento mental durante a leitura. Como a complexidade do processo implica em várias possibilidades de problemas, Perfetti (2001) reviu o modelo de modo a incluir o que pode falhar quando alguém lê um texto. $\mathrm{O}$ esquema reafirma a importância da memória de trabalho em todas as etapas. A Figura 5 reproduz o modelo com a indicação de potenciais problemas, conforme a publicação original em inglês.

Perfetti (2001) classificou o seu modelo como "uma organização da arquitetura cognitiva da leitura", definindo assim as etapas envolvidas:

\begin{abstract}
A leitura começa com (a) um input visual que, com o uso imediato da fonologia, leva à identificação da palavra que (b) produz informações semânticas relacionadas à palavra conforme as limitações do contexto. A palavra é de imediato (c) integrada sintaticamente à computação da frase em questão e (d) semanticamente com uma interpretação (proposição) da mensagem em questão. Conforme as frases são lidas (e), desenvolve-se uma representação integrada do texto, que consiste em proposições inter-relacionadas. Para estabelecer uma compreensão razoavelmente específica de um texto, (f) as inferências definem um modelo referencial coerente do que está sendo lido. Dificuldades de leitura têm o potencial de ocorrer em cada componente $^{30}$. (PERFETTI, 2001, p. 12801)
\end{abstract}

\footnotetext{
${ }^{30}$ Original em inglês: Reading begins with (a) a visual input that, with immediate use of phonology, leads to word identification that (b) yields semantic information connected to the word as constrained by the current context. A word immediately is (c) integrated syntactically with an ongoing sentence parse and (d) semantically with an ongoing message interpretation (proposition). As sentences are read (e), an integrated text representation is developed, consisting of interrelated propositions. To establish a reasonably specific understanding of a text, (f) inferences establish a coherent referential model of what is being read. Potential reading difficulties are seen in each component.
} 


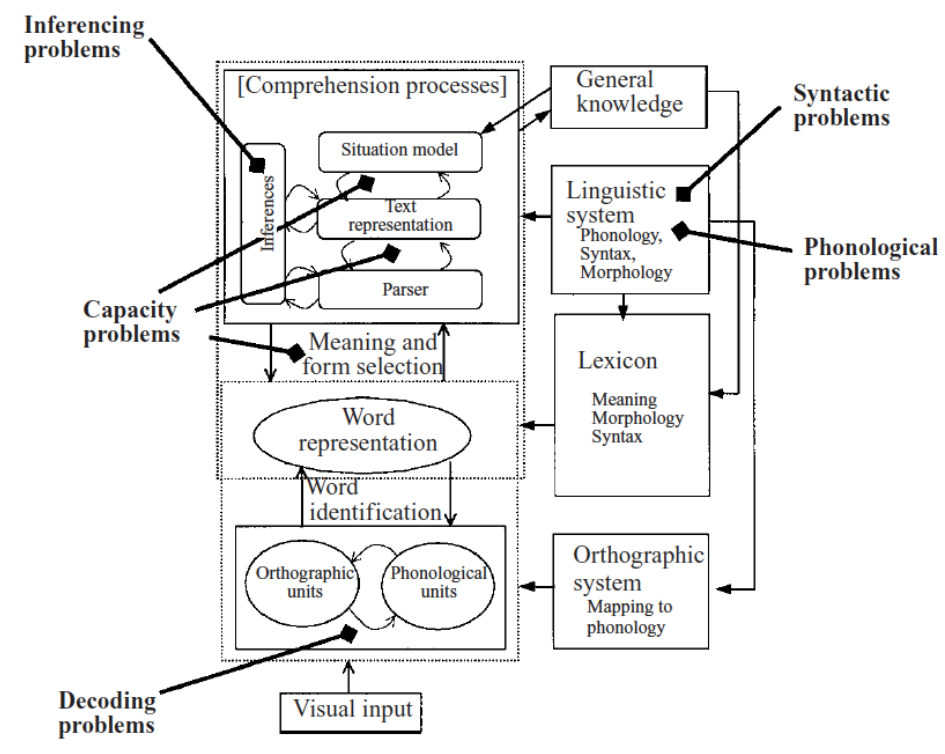

Figura 5: Modelo de Compreensão Leitora com indicação de gargalos onde podem ocorrer problemas (PERFETTI, 2001)

A cada etapa representada no modelo estão associadas diferentes possibilidades de falha de compreensão.

Problemas no processamento de palavras são os grandes responsáveis por problemas de leitura. Quem não lê bem as palavras, não consegue compreender o texto. Perfetti (1999, p. 191) afirma que "a teoria da eficiência verbal pressupõe que leitores sem procedimentos eficientes de codificação de palavras correm o risco de falhar na compreensão". ${ }^{31}$ Perfetti, Landi e Oakhill (2005, p. 229) reafirmam que “a compreensão não terá êxito sem a identificação das palavras e a recuperação de seus significados". ${ }^{32}$ Leitores menos capacitados têm dificuldade para descartar sentidos de palavras que não se aplicam ao contexto, mantendo-os ativados por pelo menos um segundo - mais uma vez, a memória de trabalho desempenha papel importante. E só é possível inferir o sentido de um texto quando a maioria das palavras é conhecida.

Também é possível ocorrer falhas no processamento sintático, especialmente em leitores menos capacitados. Perfetti (1999) pontua que tais falhas podem ser causadas não por deficiência sintática, mas por problemas de processamento

\footnotetext{
${ }^{31}$ Original em inglês: Verbal efficient theory assumes that readers who lack efficient word-coding procedures are at risk for comprehension failure.

${ }^{32}$ Original em inglês: Comprehension cannot be successful without the identification of words and the retrieval of their meanings.
} 
fonológico ou por gargalos na capacidade de processamento mental. Mais uma vez vê-se o papel nevrálgico da capacidade de memória de trabalho para lidar com estruturas complexas de sentenças.

Diversos problemas podem surgir no processamento em nível do texto e na geração de inferências. Para Perfetti (1999), quem tem deficiências de compreensão terá dificuldade para detectar questões de coerência no texto, como, "por exemplo se parágrafos consecutivos são sobre tópicos não relacionados". ${ }^{33}$ Leitores precisam usar seu conhecimento de mundo para gerar inferências que complementem a compreensão do texto, o que também pode ser uma fonte de problemas. Além disso, quem tem mais facilidade para compreender terá mais facilidade para gerar inferências. Do mesmo modo, quem tem mais dificuldade de compreensão terá mais dificuldade para inferir.

Os leitores com menor capacidade de compreensão não sabem quando é apropriado fazer inferências. Eles enfrentam limitações de processamento, o que dificulta sua habilidade de fazer inferências e integrar informações de texto que requer conhecimento prévio. $^{34}$ (PERFETTI, LANDI E OAKHILL, 2005, p. 231)

Enquanto Perfetti (2001) classifica como "deletérios" os efeitos da pouca habilidade para ler, Perfetti, Landi e Oakhill (2005) observam que "o gênero dos textos (narrativo, descritivo, etc.), seu estilo linguístico e diferentes layouts podem gerar novos problemas que só são solucionados com experiência em leitura”.

\subsection{4.}

\section{Aspectos que facilitam a compreensão}

A partir dos trabalhos de Perfetti, percebe-se a importância de escolher palavras e estruturar frases que minimizem os problemas que podem ocorrer nas diversas etapas do processamento mental. No que tange a palavras, as mais frequentemente escritas e frequentemente faladas tendem a ser processadas mais rápido, pois acionam a rota que é "endereçada". O significado de uma palavra pode variar com as circunstâncias. Como o leitor tende a decidir pelo significado mais

\footnotetext{
${ }^{33}$ Original em inglês: For example, whether successive paragraphs are on unrelated topics.

34 Original em inglês: Less-skilled comprehenders do not know when it is appropriate to draw inferences. Less-skilled comprehenders have processing limitations, which hamper their ability to make inferences and integrate text information with prior knowledge.
} 
recorrente, é relevante estar claro o contexto de uso da palavra. Extensão ortográfica e fonológica, consistência da ortografia e leque de significados também exercem influência na compreensão.

Se leitores menos competentes têm sistemas semântico e lexical fracos, pode-se esperar que variáveis semânticas que reflitam o funcionamento deste sistema façam diferença. Por exemplo, significados concretos são ativados mais prontamente do que significados mais abstratos ${ }^{35}$. (PERFETTI, LANDI E OAKHILL, 2005, p.241)

A computação sintática também causa impactos no processamento de frases e na compreensão do texto. Quanto mais enxuta a estrutura sintática, mais rápido a frase será processada.

Na perspectiva da Psicolinguística, a compreensibilidade textual costuma ser considerada em termos das representações e operações mentais envolvidas no processamento de textos, e conforme os fatores que podem afetar esse processamento durante a leitura. Deve-se levar em conta tanto aspectos associados ao texto (vocabulário, estrutura sintática, ligação entre as sentenças, etc.) como características do leitor (nível de proficiência leitora, conhecimento de mundo, conhecimento do assunto do texto, familiaridade com gêneros textuais, etc.). Acrescentem-se ainda fatores relacionados ao suporte em que o texto é apresentado, condições de leitura e aspectos motivacionais, entre outros.

\section{5.}

\section{Síntese do capítulo 2}

O capítulo definiu o conceito de compreensibilidade e mostrou as convergências entre Ergonomia, Design da Informação e Psicolinguística no que diz respeito a compreender informações escritas. Em maior ou menor grau, as três disciplinas avaliam os custos de processamento mental, caracterizam os problemas que podem ocorrer na leitura e sinalizam como facilitar o entendimento.

Para a Ergonomia, todo sistema deve se adequar às necessidades de quem o utiliza para garantir que as tarefas serão desempenhadas com segurança e eficácia.

\footnotetext{
${ }^{35}$ Original em inglês: If less-skilled readers have a weak lexical semantic system, then one might expect semantic variables that reflect the functioning of this sytem to make a difference. For example, concrete meanings are more readily activated than more abstract meanings.
} 
O usuário exerce um papel tão central que pode gerar mudanças no sistema se for pelo melhor desempenho da tarefa (DE MORAES, 2002). Um dos caminhos para aprimorar o desempenho é reduzir a carga cognitiva. Como a compreensão de informações é considerada tarefa mental, designers devem estar atentos aos elementos linguísticos do texto para evitar cargas cognitivas desnecessárias (BROADBENT, 1977; BRIDGER,1995).

O Design da Informação projeta mensagens que facilitem o entendimento do usuário para atingir a clareza. Leva em conta a memória de curto prazo e a carga de processamento mental. Acredita que cabe aos designers zelar por textos compreensíveis, simples e consistentes nas peças que projetam (FRASCARA, 2004; PETTERSSON, 2012), pois a comunicação só estará concluída quando o público-alvo entender.

Para a Psicolinguística, o entendimento é resultado de diferentes processos cognitivos envolvidos na leitura e de representação mental e a memória de trabalho é um recurso fundamental à compreensão de textos. O modelo de Perfetti (2001) forneceu uma espécie de mapa do que pode dar errado nas várias etapas da compreensão leitora. Se a correta identificação das palavras não ocorrer, todos os demais processos serão comprometidos.

Os conceitos aqui discutidos serão importantes para a leitura do capítulo seguinte, que examina o estilo textual do setor público. Como será visto, o "burocratês" infringe as estratégias que favorecem o processamento mental e a compreensão de textos que já foram detalhadamente apresentadas. 


\section{3}

\section{Estilo textual do setor público ("burocratês")}

O objetivo deste capítulo é examinar o estilo de escrita típico do setor público. A linguagem burocrática, herdeira da linguagem jurídica, contraria as boas práticas de compreensibilidade que foram discutidas no capítulo 2. Assim como o "juridiquês", o burocratês é prolixo e enredado. Garner (2007) presume que a proximidade entre os dois estilos seja decorrente do papel exercido por servidores públicos, intermediários entre a lei e o público. Lidar cotidianamente com textos jurídicos teria contribuído para moldar os padrões da escrita burocrática.

O capítulo começa definindo o que é burocratês e apresentando traduções em outros idiomas. A seguir, elenca as características linguísticas que afetam a compreensibilidade textual em português, espanhol e inglês. A seguir, discute a habilidade da população brasileira para ler textos em burocratês, a partir de informações sobre nível de instrução e alfabetismo no país. Depois, o capítulo relaciona leis e programas federais que determinam clareza e facilidade de compreensão nas informações de órgãos públicos. Por fim, serão sintetizados os principais tópicos abordados.

\section{1.}

\section{Definição de burocratês e suas traduções}

Várias línguas ocidentais têm termos específicos para designar o estilo textual da burocracia. No Brasil, o verbete burocratês consta do Dicionário Houaiss da Língua Portuguesa: "Linguagem pejada de tecnicidades do jargão dos burocratas; terminologia só compreensível a burocratas". (HOUAISS e VILAR, 2001, p. 532)

\footnotetext{
${ }^{36}$ Daqui em diante, a palavra burocratês será grafada sem aspas.
} 
No português brasileiro, também circula o termo "governês" (DE MORAES, 1995; GREGÓRIO, 2011; TAMURA, 2016).

Em inglês, há os termos officialese, bureaucratese, federalese e gobbledygook, todos dicionarizados. Em italiano, existe o burocratese. Na língua alemã, chama-se Amtsdeutsch, "alemão de repartição pública" ou Beamtendeutsch "alemão de funcionários públicos". Em sueco, é kanslispråk, "linguagem de escritório". A língua espanhola parece não ter um termo específico, diz-se lenguaje burocrático.

Nesses e em outros idiomas, o estilo de escrita burocrática é marcado por estrutura sintática complexa, vocabulário pouco familiar e alta carga informacional.

\section{2.}

\section{Caraterísticas linguísticas do burocratês que afetam a compreensibilidade textual em três idiomas}

A onipresença do burocratês nas sociedades ocidentais confere uniformidade às suas características linguísticas, independentemente do idioma. A seguir, são apresentados aspectos do burocratês que são comuns no português, no espanhol e no inglês - as raras questões específicas de cada língua foram descartadas. É importante notar que cada característica linguística aqui apontada, quando usada de forma isolada, é capaz de prejudicar a leitura e a compreensão mesmo de pessoas com alta escolaridade. No burocratês, as características incidem de forma concomitante.

\subsection{1.}

\section{Português}

Em um estudo pioneiro nos anos 1980, a linguista brasileira Neide Rodrigues de Souza Mendonça assim definiu o estilo:

A linguagem burocrática - burocratês, prosa institucional ou linguagem da burocracia - é uma subvariedade escrita da língua materna, usada pelos membros da administração durante o seu trabalho. É encontrada nos documentos que emanam das instituições públicas (municipais, estaduais e federais) e privadas. [...] O 
psicolinguista Frank Smith afirma que, algumas vezes, a linguagem usada por médicos, advogados e burocratas é de difícil compreensão e que essa incompreensibilidade é voluntariamente criada. (MENDONÇA, 1987, p. 11)

Mendonça (1987) observa que o burocratês não pode ser considerado um dialeto, pois é adquirido artificialmente. Também não se configuraria como jargão, pois, além do nível lexical, inclui sintaxe e organização do discurso. Ela analisou as características do burocratês nesses três níveis - discursivo, sintático e lexical, destacando aspectos em comum com a linguagem jurídica.

No nível do discurso, a autora destaca que tanto a linguagem burocrática quanto a linguagem jurídica evitam pronomes e não consideram o contexto no qual o documento será usado. Ela frisa que redatores burocráticos desconsideram a perspectiva do cidadão, provocando frustração. Quanto à estrutura da informação, o juridiquês e o burocratês pecam por falta de organização e falta de orientação para o leitor.

No nível sintático, ambos apresentam períodos e parágrafos excessivamente longos, negativas múltiplas, orações e frases mal colocadas e intercaladas. Há um abuso da voz passiva (em que é possível omitir o agente da ação).

Os burocratas parecem pensar que, escondendo o agente da ação, esconderão também a sua responsabilidade pessoal nos julgamentos e decisões que são, na verdade, subjetivos. Preferir usar a voz passiva, em vez da ativa, não torna os textos mais difíceis de ser decodificados. Essa dificuldade surge quando passagens inteiras são colocadas na voz passiva sem envolverem agentes humanos. (MENDONÇA, 1987, p. 16-17)

As nominalizações são outra característica sintática do burocratês. Para a autora, substituir pronomes, verbos e adjetivos por nomes acentua o formalismo e a abstração:

Usando nomes para modificar nomes, isto é, com função de adjetivos, formam-se cadeias de nomes. Essa característica é específica da linguagem burocrática. Para a burocracia, se você é funcionário público, você faz parte do 'Quadro do Pessoal Permanente do Serviço Público do Poder Executivo' [...] O pequeno agricultor que necessita de ajuda financeira para seu projeto deverá dirigir-se à 'Coordenadoria de Apoio a Unidades de Produção Agropecuária'. (MENDONÇA, 1987, p. 18)

A autora adverte que cadeias de nomes não só dificultam a compreensão dos textos, mas também são geradoras de siglas, outro entrave ao entendimento: 
Essas cadeias de nomes servem, em geral para designar instituições e programas e podem ser convertidas em siglas [...]. Quanto às siglas, elas podem ser um entrave à compreensão textual [...] Esse abuso de siglas serve para separar as pessoas que 'estão por dentro', que dominam a informação, das que 'estão por fora', que não possuem esse tipo de informação, criando a solidariedade do grupo profissional (MENDONÇA, 1987, p. 19)

Em relação ao nível lexical, além das siglas, destaca-se o uso de palavras e expressões pouco usuais, termos técnicos, palavras em latim e jargão. A autora observa que "quando o jargão burocrático se junta a um outro jargão técnico, a inteligibilidade da mensagem fica difícil".

Além de analisar as características linguísticas do burocratês, o estudo de Neide Mendonça propôs um modelo procedural de redação de documentos para guiar a formação de redatores. A autora também compôs um check-list de comprensibilidade textual (Lista Avaliativa para Problemas Linguísticos) e um padrão para a avaliação de documentos centrada no leitor para analisar usabilidade.

Ao analisar as estruturas da linguagem burocrática, Silveira (2008) apontou que o uso de fórmulas arcaicas e empoladas "faz o burocratês parecer uma linguagem para iniciados, de caráter excludente". E adverte para os problemas que este estilo causa à compreensibilidade dos textos:

\begin{abstract}
Além do uso de terminologias técnicas específicas, a linguagem burocrática, quando revestida de suas tradicionais características estilísticas, se transforma em um sério problema de compreensão para as pessoas externas às suas comunidades discursivas, ou seja, para as pessoas que não estão diretamente ligadas aos setores da burocracia administrativa em instituições públicas e particulares. (SILVEIRA, 2008, p. 224)
\end{abstract}

Silveira indica a formalidade e a impessoalidade como principais marcas linguísticas do burocratês. A formalidade fica expressa na escolha de vocativos, pronomes de tratamento, fórmulas de polidez, fórmulas de saudação e rebuscamento de vocabulário, com eufemismos, termos abstratos, jargão burocrático e arcaísmo. O tom impessoal fica evidente sobretudo por usar a voz passiva e as nominalizações, além de evitar a referência anafórica pronominal (repetir um elemento anteriormente expresso na frase usando pronomes). 


\title{
3.2.2.
}

\section{Espanhol}

As fronteiras entre a linguagem jurídica e a linguagem da administração do Estado são igualmente tênues em língua espanhola. Elena de Miguel (2000) aponta que ambas costumam ser estudadas em conjunto, pois "compartilham os mesmos recursos linguísticos (gramaticais e lexicais) e também coincidem nos fatores extralinguísticos (canal, remetente, receptor e intenção comunicativa)".37

Quanto a aspectos gramaticais e léxicos, a linguista observa que o estilo jurídico-administrativo em espanhol é marcado pelo uso excessivo de construções passivas; grande incidência de nominalizações; exagero de subordinações; grande extensão dos parágrafos; alta recorrência de advérbios; uso abundante de siglas e abreviaturas. A autora aponta ainda os reiterados erros de ortografia e de construção de frases, bem como o uso redundante do termo "o mesmo", como aspectos característicos da escrita da administração pública em espanhol. A incidência concomitante de tais elementos resulta em um texto "complexo e obscuro, chegando, por vezes, a ser ininteligível”. ${ }^{38}$ (DE MIGUEL, 2000)

A argentina Grisela Casabone, professora da faculdade de Jornalismo e Comunicação Social da Universidade de La Plata, especialista em comunicação pública, também tem uma visão crítica sobre a linguagem burocrática.

\begin{abstract}
A burocracia designaria, no momento atual, uma anomalia, uma deformação do âmbito de gestão pública, que se naturalizou e, portanto, é reproduzida como regra e rotina pesada: a forma mata o conteúdo e, portanto, temos uma prosa - de alguma maneira é preciso chamá-la - massuda, barroca, imprecisa, gramaticalmente incorreta, ininteligível e, até mesmo, de legalidade duvidosa ${ }^{39}$. (CASABONE, 2016, p.5)
\end{abstract}

\footnotetext{
${ }^{37}$ Original em espanhol: "En consecuencia, ambos lenguajes suelen estudiarse de forma conjunta, decisión que parece sensata, puesto que comparten los recursos lingüisticos (gramaticales y léxicos) y coinciden también en los factores extralingüisticos que los caracterizan (el canal, el emisor, el receptor y la finalidad o intención comunicativa)."

${ }^{38}$ Original em espanhol: "el texto resultante es complejo y oscuro y, a veces, llega a ser ininteligible".

${ }^{39}$ Original em espanhol: "Lo burocrático designaría, en la actualidad, una anomalía, una deformación propia del ámbito de la gestión de lo público, que se ha naturalizado y que por ello se reproduce como regla y pesada rutina: forma mata contenido y asi tenemos una prosa-de alguna manera hay que llamarla-pastosa, barroca, imprecisa, gramaticalmente incorrecta, ininteligible e, incluso, de dudosa legalidad."
} 
A autora destaca as seguintes características linguísticas da linguagem burocrática: uso excessivo de construções passivas, de termos anafóricos como "o mesmo" e de imprecisões; alteração da ordem canônica das orações; uso de parágrafos extensos e com excessos de subordinadas; uso incorreto de gerúndio; uso de tecnicismos e expressões poucos usuais; uso de eufemismos, circunlóquios, muletas e arcaísmos; presença de palavras extensas; abundância de siglas e de abreviações. Na sua perspectiva, "quanto mais complicada a escrita, mais complicado o procedimento, mais distante e impessoal a relação com os cidadãos e menos transparente - e duvidosa - a qualidade do serviço prometido". ${ }^{40}$ (CASABONE, 2016)

Casabone (2016) destaca o fato de textos públicos serem repletos de erros de gramática e sintaxe, o que seria mais um sinal de "falta de motivação, descompasso entre o que se diz e o que se faz, esquecimento das necessidades, dos direitos e das verdades que estão sendo processadas" ${ }^{\prime 1}$. Ela compreende Estado e escrita como um binômio inseparável, lamentando que as relações entre burocracia e cidadania sejam pouco estudadas.

\subsection{3. \\ Inglês}

Assim como no espanhol e no português, também no inglês a linguagem jurídica costuma ser analisada em conjunto com a linguagem burocrática. Danet (1983) elenca características comuns a ambos estilos, notando que "o burocratês governamental geralmente nos parece mais pitoresco, quando não enlouquecedor"42: vocabulário técnico, palavras em latim, nominalizações, uso intenso de voz passiva, uso de condicionais complexos, múltiplas negativas difíceis de processar, linguagem impessoal, sentenças longas e estruturalmente complexas. A linguista americana observa que a dificuldade de compreensão de tais elementos é amplamente comprovada em pesquisas:

\footnotetext{
${ }^{40}$ Original em espanhol: "Cuanto más enrevesada la escritura, más complicado el trámite, más distante e impersonal la relación con la ciudadanía y menos transparente - y dudosa - la calidad del servicio que promete."

${ }^{41}$ Original em espanhol: "la falta de motivación, el desvínculo entre lo que se enuncia y lo que se gestiona, el olvido de las necesidades, de los derechos, de las verdades que se tramitan"

${ }^{42}$ Original em inglês: "government bureaucratese is what we most often find amusing, if not maddening."
} 
Palavras pouco comuns são menos lembradas e compreendidas, e palavras concretas ajudam na retenção de informações. Porém, a sintaxe é mais importante do que o vocabulário: nominalizações, certos tipos de passivas, negativas, exclusões e sentenças com muitas orações causam dificuldade de compreensão. Características no nível textual dos documentos legais e burocráticos também trazem problemas para os leitores. A falta de coesão entre as sentenças, por falta de pronomes que refiram-se a pessoas e órgãos antes mencionados, é uma dessas fontes de dificuldade. ${ }^{43}$ (DANET, 1983, p.52)

Quanto às características que são particulares da linguagem burocrática, Danet destaca o uso de sequências de substantivos - como em "serviço de informação ao consumidor" - e a grande incidência de jargão.

Aitchinson (1986) cunhou as expressões gobbledygook syndrome (síndrome do burocratês) e jargonitis (jargonite) para caracterizar a sintaxe "desajeitada" e o excesso de jargão que caracterizam textos jurídicos e burocráticos. A linguista britânica assinala a existência de "uma área nebulosa na qual uns veem o vocabulário desconhecido como terminologia essencial mas outros acham uma mistificação sem sentido" ${ }^{44}$.

Cada incidência de jargão deve ser examinada à parte, e vários fatores devem ser considerados nesta avaliação. É inadequado usar a mesma linguagem dentro e fora de um grupo profissional. (...) Uma razão para o jargão, então, é a falta de sensibilidade com as necessidades dos outros. Porém, uma segunda razão é o excesso de sensibilidade. Isto gera eufemismos, pois pode-se evitar uma palavra existente, porque ela transmite uma impressão enganosa ou desagradável. ${ }^{45}$ (AITCHINSON, 1986, p.8)

As análises do burocratês em inglês, espanhol e português mostraram que os mesmos elementos linguísticos afetam a compreensibilidade da informação pública em três idiomas. Se a incidência isolada de cada elemento linguístico já dificulta a

\footnotetext{
${ }^{43}$ Original em inglês: "Uncommon words are more poorly remembered and understood than common ones, and concrete words aid retention of information. Syntax, however, is more important than vocabulary: nominalizations, certain kinds of passives, negatives, deletions of the kind illustrated, and sentences containing many embedded clauses all cause comprehension difficulties. Text-level characteristics of legal and bureaucratic documents also pose problems for readers. The lack of cohesion between sentences, because of the failure to use pronouns to refer back to previously mentioned persons and entities, is one such source of difficulty."

${ }^{44}$ Original em inglês: "there is a hazy área in which unifamiliar vocabular is regarded as essential terminology by some but as pointless mystification by others."

${ }^{45}$ Original em inglês: "Each instance of jargon must be examined separately, and a number of factors need to be taken into consideration when assessing such language.It is inappropriate to use the same language to those inside and outside a professional group. (...) One reason for jargon, then, is a lack of sensitivity to the needs of others. But a second reason is over-sensitivity. This results in euphemisms, since an existing word may be avoided because it gives a misleading or unpleasant impression."
} 
leitura mesmo de pessoas com alta escolaridade, evidentemente a incidência conjunta deles em textos governamentais gera enormes prejuízos para a população e para a máquina pública.

O Quadro 1 compila os problemas apontados por Mendonça (1987), Silveira (2008), Miguel (2000), Casabone (2016), Danet (1983) e Aitchinson (1983).

\begin{tabular}{|c|c|c|c|c|c|c|}
\hline \multirow[t]{2}{*}{ Problemas do burocratês } & \multicolumn{6}{|c|}{ Autoras } \\
\hline & $\begin{array}{l}\text { Mendonça } \\
\text { (1987) }\end{array}$ & $\begin{array}{l}\text { Silveira } \\
(2008)\end{array}$ & $\begin{array}{l}\text { Miguel } \\
(2000)\end{array}$ & $\begin{array}{l}\text { Casabone } \\
(2016)\end{array}$ & $\begin{array}{l}\text { Danet } \\
\text { (1983) }\end{array}$ & $\begin{array}{c}\text { Aitchinson } \\
\text { (1986) }\end{array}$ \\
\hline LEXICAIS & & & & & & \\
\hline arcaísmos & & - & & - & & \\
\hline eufemismos & & - & & - & & \\
\hline jargão & - & - & & & - & - \\
\hline nominalizações & & & & & - & \\
\hline palavras em latim & - & & & 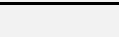 & $\bullet$ & \\
\hline palavras extensas & & & & - & & \\
\hline palavras poucos comuns & - & & & - & - & \\
\hline siglas e abreviações em excesso & - & . & - & - & & \\
\hline termos abstratos & & - & & & - & \\
\hline termos técnicos & - & - & & $\bullet$ & - & \\
\hline & & & & & & \\
\hline SINTÁTICOS & & & & & & \\
\hline advérbios em excesso & & - & - & & & \\
\hline anafóricos & & - & & - & & \\
\hline cadeias de nomes & - & & & & . & \\
\hline condicionais complexos & . & & & W & - & \\
\hline evita pronomes & - & & & . & - & \\
\hline \begin{tabular}{|l|} 
exclusões \\
\end{tabular} & & & & 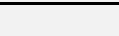 & - & \\
\hline gerúndio incorreto & 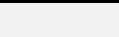 & & & - & & \\
\hline negativas múltiplas & - & . & & & - & \\
\hline nominalizações & - & - & - & 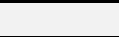 & - & \\
\hline $\begin{array}{l}\text { orações e frases mal colocadas e } \\
\text { intercaladas. }\end{array}$ & - & & - & - & & \\
\hline ordem indireta & & - & & - & & \\
\hline passivas em excesso & - & - & - & - & - & \\
\hline periodos longos & - & & & & - & \\
\hline sequências de substantivos & - & & & & - & \\
\hline sintaxe complexa & - & & - & 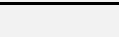 & - & - \\
\hline subordinações em excesso & & & - & - & & \\
\hline & & & & & & \\
\hline OUTROS & & & & & & \\
\hline $\begin{array}{l}\text { desconsiderar o contexto de uso do } \\
\text { documento }\end{array}$ & - & & & & & \\
\hline desconsiderar a perspectiva do cidadão & - & & & & & \\
\hline falta de orientação para o leitor & - & & & & & \\
\hline má organização da informação & - & & & & & \\
\hline formalidade & & - & & & & \\
\hline impessoalidade & & - & & & - & \\
\hline imprecisões & & & & - & & \\
\hline parágrafos extensos & - & & - & & & \\
\hline erros de ortografia & & & • & - & & \\
\hline
\end{tabular}

Quadro 1: Problemas do burocratês conforme Mendonça (1987), Silveira (2008), Miguel (2000), Casabone (2016), Danet (1983) e Aitchinson (1983). 


\section{3.}

\section{Habilidade da população brasileira para ler textos em burocratês}

Examinar os dados sobre a educação de jovens e adultos no Brasil pode contribuir para avaliar o prejuízo social que a incompreensibilidade textual causa à cidadania e à máquina pública. Buscaram-se dados que considerassem a faixa etária partir de 14 anos, pois, nesta idade, já é possível entrar no mercado de trabalho como aprendiz, conforme a legislação em vigor (BRASIL, 2000). Começar a trabalhar pressupõe começar a se relacionar com direitos e deveres trabalhistas e tomar decisões previdenciárias, entre outros eventos da vida profissional que requerem a leitura de textos governamentais.

Assim, foram reunidos dados dos seguintes indicadores:

- Pesquisa Nacional por Amostra de Domicílios Contínua (PNAD Contínua) realizada pelo Instituto Brasileiro de Geografia e Estatística (IBGE);

- Indicador de Alfabetismo Funcional (INAF), uma realização conjunta da ONG Ação Educativa e do Instituto Paulo Montenegro;

- Programme for International Student Assessment-PISA (Programa Internacional de Avaliação de Alunos), estudo conduzido pela Organização para a Cooperação e Desenvolvimento Econômico (OCDE).

Para contextualizar as informações a seguir, é importante saber que a educação escolar no Brasil é composta por educação básica e educação superior, conforme estabelece a Lei de Diretrizes e Bases da Educação Nacional (BRASIL, 2013). A educação básica divide-se em educação infantil (creche e pré-escola), ensino fundamental (duração de 9 anos) e ensino médio (duração de 3 anos). A educação superior inclui cursos de graduação, pós-graduação, sequenciais e de extensão. A duração da educação superior varia de acordo com o tipo de curso, sendo um mínimo de 2 anos para cursos tecnológicos.

\subsection{1.}

\section{Dados do IBGE}

A Pesquisa Nacional por Amostra de Domicílios Contínua (PNAD Contínua) quantifica anualmente a taxa de analfabetismo e os níveis de instrução dos 
brasileiros. Os níveis de instrução consideram a população com 25 anos ou mais de idade, pois tal grupo etário que já poderia ter concluído o processo regular de escolarização. Em 2019, mais da metade da população com essa faixa etária não havia concluído o ensino médio e só $17,4 \%$ havia completado o ensino superior. A taxa de pessoas sem instrução era de $6,4 \%$, ou seja, havia 10,6 milhões de analfabetos no país (IBGE, 2020). A Tabela 1 mostra a distribuição da população por níveis de instrução conforme a PNAD Contínua 2019.

\begin{tabular}{lc}
\hline Nível de instrução & Percentual \\
\hline Sem instrução & $6,4 \%$ \\
Ensino Fundamental incompleto & $32,2 \%$ \\
Ensino Fundamental completo & $8,0 \%$ \\
Ensino Médio incompleto & $4,5 \%$ \\
Ensino Médio completo & $27,4 \%$ \\
Ensino Superior incompleto & $4,0 \%$ \\
Ensino Superior completo & $17,4 \%$ \\
\hline
\end{tabular}

Tabela 1: Níveis de instrução da população brasileira com 25 anos ou mais de idade. Fonte: Pesquisa Nacional por Amostra de Domicílio Contínua (PNAD) 2019/ IBGE.

A PNAD Contínua indica que, quanto mais velho o grupo populacional, maior é a proporção de analfabetos. Em 2019, havia quase 6 milhões de analfabetos com 60 anos ou mais. Isso significa uma taxa de analfabetismo de $18 \%$ no grupo etário que tende a intensificar o uso de serviços públicos em saúde e previdência social e, consequentemente, tende a necessitar de serviços públicos, cujo acesso inicial se faz majoritariamente a partir de sites governamentais.

\subsection{2.}

\section{Dados do INAF}

O Indicador de Alfabetismo Funcional (Inaf) é o único índice nacional sobre os níveis de alfabetismo da população brasileira. A delimitação da faixa etária entre 15 e 64 anos de idade indica a ênfase do estudo na população que está no mercado de trabalho. Para o Inaf, alfabetismo é 
a capacidade de compreender e utilizar a informação escrita e refletir sobre ela, um contínuo que abrange desde o simples reconhecimento de elementos da linguagem escrita e dos números até operações cognitivas mais complexas, que envolvem a integração de informações textuais e dessas com os conhecimentos e as visões de mundo aportados pelo leitor. Dentro desse campo, distinguem-se dois domínios: o das capacidades de processamento de informações verbais, que envolvem uma série de conexões lógicas e narrativas, denominada pelo Inaf como letramento, e as capacidades de processamento de informações quantitativas, que envolvem noções e operações matemáticas, chamada numeramento. (LIMA; CATELLI JR., 2018, p. 4)

O Inaf determina a escala de alfabetismo da população aplicando um teste e um questionário:

O estudo é organizado com base em um teste cognitivo e um questionário contextual. Os itens que compõem o teste de Alfabetismo envolvem a leitura e interpretação de textos do cotidiano (bilhetes, notícias, instruções, textos narrativos, gráficos, tabelas, mapas, anúncios, etc). $\mathrm{O}$ questionário contextual aborda características sociodemográficas e práticas de leitura, escrita e cálculo que os sujeitos realizam em seu dia a dia. (LIMA; CATELLI JR., 2018, p.6)

A pesquisa estratifica o alfabetismo em cinco níveis. A descrição dos níveis a seguir considerou apenas as competências de leitura, pois as competências de escrita e de matemática fogem ao escopo desta dissertação:

Analfabeto: Não consegue realizar tarefas simples envolvendo a leitura de palavras e frases;

Rudimentar: Localiza uma ou mais informações explícitas, expressas de forma literal, em textos muito simples (calendários, tabelas simples, cartazes informativos) compostos de sentenças ou palavras familiares do cotidiano doméstico;

Elementar: Seleciona uma ou mais unidades de informação, observando certas condições, em textos diversos de extensão média; realiza pequenas inferências;

Intermediário: Localiza informação expressa de forma literal em textos diversos (jornalístico e/ou científico), realizando pequenas inferências; Interpreta e elabora síntese de textos diversos (narrativos, jornalísticos, científicos), relacionando regras com casos particulares com o reconhecimento de evidências e argumentos e confrontando a moral da história com a sua própria opinião ou senso comum; Reconhece o efeito de 
sentido ou estético de escolhas lexicais ou sintáticas, de figuras de linguagem ou sinais de pontuação.

Proficiente: Elabora textos de maior complexidade (mensagem, descrição, exposição ou argumentação) com base em elementos de um contexto dado e opina sobre o posicionamento ou estilo do autor do texto; resolve situaçõesproblema relativos a tarefas de contextos diversos, que envolvem diversas etapas de planejamento, controle e elaboração, que exigem retomada de resultados parciais e o uso de inferências.

O Inaf aponta a escolaridade como o principal fator explicativo da condição de alfabetismo, mas alerta que essa relação não é absoluta ou linear:

Há uma significativa proporção de pessoas que, por exemplo, mesmo tendo chegado ao ensino médio e ao superior, não conseguem alcançar os níveis mais altos da escala de alfabetismo, como seria esperado para esses níveis de escolaridade. (LIMA; CATELLI JR., 2018, p. 10)

A Tabela 2 indica a distribuição da população brasileira por níveis de alfabetismo segundo o Inaf 2018. O critério de arredondamento das frações dos resultados permite percentuais totais diferentes da soma dos números arredondados.

\begin{tabular}{lc}
\hline Nível de alfabetismo & Percentual \\
\hline \multirow{2}{*}{ Analfabeto } & $8 \%$ \\
Rudimentar & $22 \%$ \\
Elementar & $34 \%$ \\
Intermediário & $25 \%$ \\
Proficiente & $12 \%$ \\
\hline
\end{tabular}

Tabela 2: Níveis de alfabetismo da população brasileira entre 15 e 64 anos de idade. Fonte: Indicador de Alfabetismo Funcional (INAF) 2018.

A soma dos grupos Analfabeto e Rudimentar compõe a condição de analfabetismo funcional, indicando que $29 \%$ da população são analfabetos funcionais. ${ }^{46}$

\footnotetext{
${ }^{46}$ Esse percentual desconsidera o arredondamento das frações da Tabela 2, conforme o próprio
} relatório Inaf o faz ao somar os grupos Analfabeto e Rudimentar. 
Em todas as faixas etárias, é significativa a proporção de pessoas no nível Elementar. Este nível representa $34 \%$ da população:

Mais de 3 a cada 10 brasileiros entre 15 e 49 anos, embora funcionalmente alfabetizados, têm significativas limitações para relacionar-se com as demandas cotidianas de uma sociedade letrada. (LIMA; CATELLI JR., 2018, p. 14)

Enquanto os $25 \%$ do nível Intermediário realizam pequenas inferências, elaboram sínteses e reconhecem figuras de linguagem, apenas os 12\% do nível Proficiente elaboram textos de maior complexidade e realizam inferências em situações relacionadas a tarefas.

Confirmando que alta escolaridade não é fator determinante para alto alfabetismo, o Inaf constatou que só $34 \%$ de quem ingressa ou conclui o ensino superior alcança o nível Proficiente.

Há uma predominância de pessoas acima de 50 anos entre os níveis inferiores da escala de alfabetismo: $58 \%$ dos analfabetos e 36\% dos que têm nível Rudimentar estão acima dos 50 anos.

Os dados do Inaf confirmam o que os números do IBGE indicam: a maior parcela da população brasileira com idade para participar ativamente da sociedade tem dificuldade para compreender textos extensos, compostos por múltiplas informações e sem palavras familiares - tais como os textos governamentais escritos em burocratês. A parcela acima de 50 anos tende a ser mais prejudicada ${ }^{47}$. Só $10 \%$ dos que têm nível Proficiente são maiores de 50 .

\subsection{3.}

\section{Dados do PISA}

O PISA é um estudo comparativo internacional realizado a cada três anos com estudantes que têm 15 anos de idade, em 79 países, incluindo países membros e não-membros da Organização para a Cooperação e Desenvolvimento Econômico (OCDE). O PISA avalia o desempenho estudantil em três áreas cognitivas - Leitura,

\footnotetext{
${ }^{47}$ Além de faixa etária, o Inaf apresenta outras variáveis relevantes ao analisar o alfabetismo no Brasil, como cor/ raça. Foi aqui destacada a faixa etária acima de 50 anos por representar o grupo populacional com maior potencial de relacionar-se com a Previdência Social. O estudo experimental da presente pesquisa testou a compreensibilidade de um benefício do INSS, conforme será relatado no capítulo 7 .
} 
Matemática e Ciências. Em 2018, o domínio principal foi Leitura: os estudantes responderam a um maior número de itens no teste dessa área.

O PISA define fluência em leitura como

\begin{abstract}
a facilidade e a eficiência com que se pode ler e entender um trecho de um texto. Mais especificamente, inclui a habilidade de ler palavras e textos com precisão e automaticamente e, em seguida, analisá-los, fraseá-los e processá-los para compreender o significado geral do texto (INEP, 2018, p.53)
\end{abstract}

Em 2018, a matriz do PISA trabalhou com duas categorias de processos cognitivos de leitura: processamento de texto e gerenciamento de tarefas. Quanto ao processamento de texto, a avaliação incluiu etapas relacionadas a localizar informações (acessar e recuperar informações dentro do texto, buscar e selecionar o texto relevante), compreender (representar o significado literal; integrar e gerar inferências), avaliar e refletir (avaliar qualidade e credibilidade; refletir sobre o conteúdo e a forma; detectar e lidar com conflitos).

A escala de letramento em Leitura do PISA estabelece os níveis 1c, 1b, 1a, 2, $3,4,5,6$, em ordem crescente de proficiência.

Nível 1c - Entende e afirma o significado de frases curtas e sintaticamente simples em um nível literal;

Nível 1b-Avalia o significado literal de frases simples. Consegue interpretar o significado literal dos textos, fazendo conexões simples entre informações adjacentes à pergunta e/ou ao texto;

Nível 1a - Entende o significado literal de frases ou passagens curtas. Consegue reconhecer o tema principal ou o objetivo do autor em um pedaço de texto sobre um tópico familiar e fazer uma conexão simples entre várias informações adjacentes ou entre as informações fornecidas e seu próprio conhecimento prévio;

Nível 2 - Consegue identificar a ideia principal em um texto de tamanho moderado. Consegue entender as relações ou interpretar o significado em uma parte específica do texto quando a informação não é destacada, produzindo inferências básicas e/ou quando o(s) texto(s) inclui(em) alguma informação distratora; 
Nível 3 - Consegue representar o significado literal de textos únicos ou múltiplos na ausência de conteúdo explícito ou de dicas organizacionais. Consegue integrar o conteúdo e gerar inferências básicas e mais avançadas.

Nível 4 - Consegue compreender trechos em configurações de texto único ou múltiplo. Interpreta o significado das nuances da linguagem em um trecho do texto, levando em consideração o texto como um todo;

Nível 5 - Consegue compreender textos longos, inferindo quais informações no texto são relevantes, mesmo que as informações de interesse possam ser facilmente ignoradas;

Nível 6 - Consegue compreender textos longos e abstratos, nos quais as informações de interesse estão profundamente interligadas, mas apenas indiretamente relacionadas à tarefa.

A Organização para a Cooperação e Desenvolvimento Econômico (OCDE) identifica o Nível 2 como nível mínimo de proficiência que todos os estudantes devem adquirir até o final do ensino médio.

A OCDE aponta que, no Nível 2, os alunos começam a demonstrar a capacidade de usar suas habilidades de leitura para adquirir conhecimento e resolver uma ampla variedade de problemas práticos. Os estudantes que não alcançam proficiência no Nível 2 em Leitura geralmente têm dificuldade quando confrontados com material que não lhes é familiar ou que é de extensão e complexidade moderadas. Eles geralmente precisam receber dicas ou instruções antes de conseguirem se envolver com um texto. (INEP, 2018, p.69)

O Brasil participa do PISA desde 2000, sendo um país que é caracterizado pelo baixo desempenho. Em 2018, ocupou o intervalo 55-58 do ranking que abrange 79 países.

A Tabela 3 traz os resultados da competência Leitura de estudantes brasileiros e a média dos estudantes dos países da OCDE. 


\begin{tabular}{lcc}
\hline $\begin{array}{l}\text { Nível de proficiência } \\
\text { em leitura }\end{array}$ & $\begin{array}{c}\text { Percentual de } \\
\text { estudantes brasileiros }\end{array}$ & $\begin{array}{c}\text { Percentual da média dos } \\
\text { estudantes da OCDE }\end{array}$ \\
\hline Abaixo de 1c & $0,4 \%$ & $0,1 \%$ \\
1c & $5,3 \%$ & $1,4 \%$ \\
1b & $17,7 \%$ & $6,2 \%$ \\
1a & $26,7 \%$ & $15,0 \%$ \\
2 & $24,5 \%$ & $23,7 \%$ \\
3 & $16,3 \%$ & $26,0 \%$ \\
4 & $7,4 \%$ & $18,9 \%$ \\
5 & $1,7 \%$ & $7,4 \%$ \\
6 & $0,2 \%$ & $1,3 \%$
\end{tabular}

Tabela 3: Níveis de competência em leitura de estudantes brasileiros e média dos resultados de estudantes dos países da OCDE no PISA 2018

Enquanto metade dos estudantes brasileiros (49,9\%) alcançou o Nível 2 ou acima, a outra metade $(50,1 \%)$ não alcançou esse nível mínimo de proficiência, o que prejudica o avanço nos estudos, a obtenção de bons trabalhos e a participação plena da sociedade.

O resultado do Brasil no PISA demonstra a falta de habilidades básicas de leitura necessárias à compreensão de informação pública escrita em burocratês. Os textos governamentais são longos, complexos e abstratos, com nuances de linguagem e informações distratoras, exigindo etapas de processamento cognitivo mais exigentes do que a capacidade média de leitura dos jovens.

\section{4 .}

Leis e programas federais que determinam informação pública fácil de compreender

Se os elementos linguísticos do burocratês prejudicam a compreensão das informações e se a população tem pouca habilidade para ler textos com tais elementos, é de se esperar que o poder público intervenha para mitigar essa situação. Nos últimos anos, uma série de leis e programas federais abordaram a questão da compreensibilidade textual da informação pública.

Em vigor desde 2012, a Lei de Acesso à Informação (LAI) é a mais importante legislação em prol da transparência de dados governamentais, do 
incremento da participação cidadã e do controle da administração pública por parte da sociedade. A lei garante a qualquer pessoa solicitar qualquer informação pública a órgãos dos poderes Executivo, Legislativo e Judiciário, sem necessidade de justificar a razão do pedido. Dois artigos da LAI abordam a clareza e a compreensibilidade da linguagem em informações governamentais. $\mathrm{O}$ artigo $5^{\circ}$ afirma ser "dever do Estado garantir o direito de acesso à informação, que será franqueada, mediante procedimentos objetivos e ágeis, de forma transparente, clara e em linguagem de fácil compreensão". Já o artigo $8^{\circ}$, sobre acessibilidade das informações, observa que os sites governamentais devem conter "ferramenta de pesquisa de conteúdo que permita o acesso à informação de forma objetiva, transparente, clara e em linguagem de fácil compreensão”. (BRASIL, 2011)

A Lei Brasileira de Inclusão da Pessoa com Deficiência é de 2015. A clareza das informações públicas consta do artigo $69^{\circ}$ (“O poder público deve assegurar a disponibilidade de informações corretas e claras sobre os diferentes produtos e serviços ofertados, por quaisquer meios de comunicação empregados, inclusive em ambiente virtual") e também consta do artigo $76^{\circ}$, que trata de direitos políticos ("garantia de que os procedimentos, as instalações, os materiais e os equipamentos para votação sejam apropriados, acessíveis a todas as pessoas e de fácil compreensão e uso").

É interessante notar que a lei define barreira como qualquer entrave que limite ou impeça a participação social da pessoa. A lei apresenta uma definição específica para "barreiras nas comunicações e na informação":

Qualquer entrave, obstáculo, atitude ou comportamento que dificulte ou impossibilite a expressão ou o recebimento de mensagens e de informações por intermédio de sistemas de comunicação e de tecnologia da informação. (BRASIL, 2015).

Considerando essa definição, parece viável inferir que o burocratês infringe a Lei Brasileira de Inclusão da Pessoa com Deficiência porque impõe barreiras à informação e dificulta o acesso a mensagens de interesse público.

Em 2017, foi sancionada a lei que ficou conhecida como Código de Defesa do Usuário do Serviço Público. $\mathrm{O}$ artigo $5^{\circ}$ aborda alguns dos elementos linguísticos que caracterizam o burocratês, ao determinar a "utilização de linguagem simples e compreensível, evitando o uso de siglas, jargões e 
estrangeirismos". Essa lei instituiu a obrigatoriedade da Carta de Serviços ao Usuário, que, conforme diz o Artigo $7^{\circ}$, “deverá trazer informações claras e precisas em relação a cada um dos serviços prestados”. (BRASIL, 2017)

A Lei Geral de Proteção de Dados (LGPD) foi sancionada em 2018, entrando em vigor em 2021. Dispõe sobre a proteção de dados pessoais e faz inúmeras menções à obrigatoriedade de clareza nas informações (BRASIL, 2018). $\mathrm{O}$ artigo $9^{\circ}$ diz que as informações sobre o tratamento de dados devem ser disponibilizadas ao titular "de forma clara, adequada e ostensiva", sendo que a requisição de consentimento será considerada nula caso as informações "não tenham sido apresentadas previamente com transparência, de forma clara e inequívoca".

Quando o artigo $14^{\circ}$ menciona o tratamento de dados pessoais de crianças e adolescentes, diz que as informações "deverão ser fornecidas de maneira simples, clara e acessível". Já o artigo $19^{\circ}$ exige que a confirmação de existência ou acesso a dados pessoais seja feita "por meio de declaração clara e completa".

$\mathrm{O}$ artigo $20^{\circ}$ determina que o controlador dos dados deve fornecer, quando solicitadas, "informações claras e adequadas a respeito dos critérios e dos procedimentos utilizados". Quanto ao tratamento de dados pessoais pelo poder público, o Artigo $23^{\circ}$ determina que sejam fornecidas "informações claras e atualizadas" relativas a esse fim. $\mathrm{O}$ artigo $41^{\circ}$ ordena que a identidade e as informações do contato do encarregado pelos dados sejam divulgadas "de forma clara e objetiva".

Por fim, o artigo 55-J diz que compete à Autoridade Nacional de Proteção de Dados garantir que "o tratamento de dados de idosos seja efetuado de maneira simples, clara, acessível e adequada ao seu entendimento".

Quanto a programas do governo federal, em 2015, foi criado o Programa Bem Mais Simples Brasil, para facilitar e agilizar a prestação de serviços públicos. $\mathrm{O}$ artigo $2^{\circ}$ destacava que as soluções tecnológicas para simplificar processos de atendimento ao cidadão e às pessoas jurídicas deveriam considerar "a utilização de linguagem simples e compreensível” (BRASIL, 2015). Em 2016, o Programa Nacional de Gestão Pública e Desburocratização - Gespública, publicou a cartilha Fugindo do burocratês: como facilitar o acesso do cidadão ao serviço público (BRASIL, 2016). A cartilha trazia orientações para a escrita em "linguagem 
cidadã”. As diretrizes serão comentadas na seção 4.5. (“Adoção de Linguagem Simples pelo setor público brasileiro").

\section{5 .}

\section{Síntese do capítulo 3}

O capítulo expôs o caráter global do burocratês. Viu-se que as fronteiras entre a linguagem jurídica e a linguagem burocrática são tênues. Mostrou que, desde os anos 1980, linguistas de vários países criticam os prejuízos que o estilo textual do setor público causa à compreensão da informação.

Os elementos linguísticos problemáticos são iguais em português, espanhol e inglês: palavras pouco familiares; excesso de jargão, tecnicismos e siglas; sentenças longas com sintaxe desajeitada; abuso de estruturas passivas e nominalizações; negativas múltiplas; parágrafos extensos e impessoalidade, entre outros.

Ao desconsiderar a perspectiva do cidadão, o burocratês separa quem está "por dentro" de quem está "por fora", acentua a exclusão social e danifica a transparência. Chega a ser incompreensível mesmo para quem tem alta escolaridade.

Os prejuízos sociais são evidentes em um país que tem baixos níveis de escolaridade e alfabetismo como o Brasil. Mais de metade da população com 25 anos ou mais não concluiu o Ensino Médio e há $29 \%$ de analfabetos funcionais. Metade dos estudantes brasileiros não tem o nível mínimo de competência em leitura para avançar nos estudos, conseguir bons trabalhos e participar plenamente da sociedade. A população mais velha tem maior dificuldade para ler e interagir com informações públicas escritas em burocratês.

Nesse cenário cognitivamente comprometido, há leis vigentes que exigem a informação fácil de compreender. O capítulo listou várias delas e apontou uma lacuna comum: a falta de orientações para alcançar a necessária compreensibilidade textual. O próximo capítulo abordará o movimento internacional que surgiu como contraponto ao burocratês, defende o direito de entender as informações e dissemina diretrizes para elaborar textos fáceis de ler. Esse movimento tem o nome de Linguagem Simples. 


\section{Linguagem Simples (Plain Language)}

Este capítulo reúne informações sobre o movimento social e a técnica de comunicação chamados Linguagem Simples, considerando a perspectiva do setor público. Como movimento e técnica, a Linguagem Simples visa transmitir informações de modo objetivo e claro. Evita os elementos linguísticos característicos do burocratês conforme apresentados na seção 3.2 de modo a aumentar a compreensibilidade textual, tema já discutido no capítulo 2 .

Primeiro, serão apresentadas traduções e definições para Linguagem Simples. Depois, será traçada uma cronologia com marcos do movimento internacional surgido nos anos 1940 e hoje presente em mais de 30 países. Logo após, será a vez de discutir como a técnica de comunicação foi sendo constituída a partir da expansão conceitual do movimento. Também serão apresentados exemplos de diretrizes. $\mathrm{O}$ capítulo prossegue listando as críticas que costumam ser dirigidas ao movimento e à técnica, além de examinar a adoção relativamente recente da Linguagem Simples no setor público brasileiro. Por último, serão sintetizados os principais pontos que o capítulo levantou.

Dada a discussão sobre Linguagem Simples ainda ser reduzida em língua portuguesa, a pesquisadora julgou cabível, ainda que pouco usual, referenciar a sua própria produção neste capítulo.

\section{1.}

\section{Traduções e definições}

Linguagem Simples é uma tradução para o termo em inglês Plain Language. $\mathrm{Na}$ língua inglesa, o adjetivo plain tem vários significados. Os que estão listados no dicionário Oxford Advanced Learner's incluem "fácil de ver, ouvir ou entender; 
claro"; "sem tentar enganar, franco e direto"; "comum e simples"48. O verbete desse dicionário também indexa a expressão in plain English, assim definindo-a: "sem rodeios, expresso de forma simples". ${ }^{49}$ (PLAIN, 1989, p. 943).

Havendo tantos significados, seria possível traduzir Plain Language como Linguagem Simples, Linguagem Clara, Linguagem Direta, Linguagem Objetiva ou Linguagem Fácil, além de outras variações. Linguagem Simples é a tradução que tem sido preferida no Brasil nos últimos dois anos. Em Portugal, a expressão usada há mais tempo é Linguagem Clara.

Em inglês, há uma nuance do termo. Enquanto Reino Unido e Nova Zelândia usam Plain English, os demais países de língua inglesa usam Plain Language. Nos países de língua espanhola, Lenguaje Claro é a tradução mais recorrente, ainda que o governo da Argentina tenha começado a usar Lenguaje Simple.

Em português e em espanhol, os termos Linguagem Cidadã e Lenguaje Ciudadano remetem aos mesmos preceitos do movimento Plain Language.

A comunidade internacional de Plain Language demorou para chegar a um consenso sobre o termo que a define. A falta de uma definição oficial era considerada um problema para o movimento (MAZUR, 2000) e um desafio permanente para quem trabalha no setor (GARWOOD, 2014).

A International Plain Language Federation (Federação Internacional de Linguagem Simples) foi fundada em 2007 por iniciativa das três associações internacionais do setor: Center for Plain Language, Clarity International e Plain Language Association International. A missão da nova entidade era construir os fundamentos necessários para firmar a Linguagem Simples como campo profissional (JAMES, 2007). Uma das primeiras iniciativas foi elaborar e pactuar uma definição para Plain Language. Schriver (2017) relata terem sido necessários seis anos de trabalho até as associações pactuarem a seguinte definição:

A communication is in Plain Language if its wording, structure, and design are so clear that the intended readers can easily find what they need, understand what they find, and use that information. (INTERNATIONAL PLAIN LANGUAGE FEDERATION, s/d)

\footnotetext{
${ }^{48}$ Original em inglês: "easy to see, hear ou understand; clear"; "not trying to deceive, frank and direct"; "ordinary and simple".

49 Original em inglês: "bluntly or simply expressed".
} 
A federação traduziu essa definição para o português usando o termo Linguagem Clara, que é preferido em Portugal:

Uma comunicação está em Linguagem Clara se as palavras, a estrutura e o design forem tão transparentes que os leitores a quem se dirige conseguem facilmente encontrar a informação de que precisam, compreender o que encontram e usar essa informação. (INTERNATIONAL PLAIN LANGUAGE FEDERATION, s/d)

Além do português, o site da federação disponibiliza a tradução de Plain Language em 20 idiomas: africâner, catalão, chinês, holandês, finlandês, francês, alemão, grego, húngaro, indonésio, irlandês gaélico, italiano, japonês, norueguês, romeno, russo, sérvio, espanhol, sueco e turco.

Pesquisadores brasileiros têm definido Linguagem Simples sob diferentes perspectivas. Martins e Filgueiras (2007) enfatizam o caráter desburocratizador e filosófico:

Plain Language pode ser definido como linguagem clara e simples ou ainda desburocratizada. Ainda pode ser considerada como uma filosofia ou tendência a favor do uso da clareza e escrita minuciosa que visa à compreensão e que tem, portanto, como objetivo tornar o texto perfeitamente apreensível para determinado público. (MARTINS; FILGUEIRAS, 2007).

A definição de Fischer (2018) abrange princípios norteadores, design da informação, elementos linguísticos e avaliação com usuários:

Linguagem clara ${ }^{50}$ é um conjunto de práticas que facilitam a leitura e a compreensão de textos. Considera o público a quem a comunicação se destina para organizar as ideias, escolher as palavras mais familiares, estruturar as frases e determinar o design. O leitor consegue localizar com rapidez a informação de que precisa, entendê-la e usá-la. Evita jargão e termos técnicos: se forem inevitáveis, deve explicá-los. Possibilita transmitir informações complexas de maneira simples e objetiva. Uma comunicação em linguagem clara é visualmente convidativa e fácil de ler porque foi escrita com esta meta. Costuma ter o tom de uma conversa amigável e respeitosa. Reconhece o direito que toda pessoa tem de entender textos relevantes para o seu cotidiano. Sua intenção primordial é esclarecer. Sempre que possível, testa se o público-alvo entendeu bem o texto antes de publicá-lo. (FISCHER, 2018)

Até 2019, era comum praticantes e pesquisadores brasileiros de Linguagem Simples reproduzirem a tradução preferida em Portugal, Linguagem Clara. Depois,

\footnotetext{
${ }^{50} \mathrm{Em}$ trabalhos posteriores, inclusive nesta dissertação, a autora passou a usar Linguagem Simples.
} 
o termo Linguagem Simples consolidou-se em debates, programas de governo e normativos.

A lei que instituiu a Política Municipal de Linguagem Simples na cidade de São Paulo ${ }^{51}$ traz as seguintes definições:

Linguagem Simples: o conjunto de práticas, instrumentos e sinais usados para transmitir informações de maneira clara e objetiva, a fim de facilitar a compreensão de textos; Texto em Linguagem Simples: o texto em que as ideias, as palavras, as frases e a estrutura são organizadas para que o leitor encontre facilmente o que procura, compreenda o que encontrou e utilize a informação. (SÃO PAULO, 2020)

\section{2.}

\section{Movimento social pela clareza na informação pública}

O movimento Plain Language começou a se constituir em meados dos anos 1940 nos Estados Unidos e no Reino Unido, depois espalhando-se para outros países, especialmente os de língua inglesa (FISCHER, 2018). O movimento defende o direito de cidadãos e consumidores compreenderem as informações que orientam o cotidiano. Prega o uso de um estilo de escrita simples, direto e objetivo como alternativa à linguagem técnica e burocrática, desnecessariamente complicada, de organizações e governos.

Williams (2015, p. 184) observa que os países onde o movimento Plain Language mais progrediu têm o inglês como língua oficial e são regrados de forma total ou híbrida pelo Direito Comum ${ }^{52}$, e não exclusivamente pelo Direito Civil. De fato, Inglaterra, País de Gales, Austrália, Nova Zelândia e Estados Unidos são regidos pelo Direito Comum. Já Canadá, África do Sul e Escócia têm formato híbrido. Esses países efetivamente são protagonistas no cenário da Linguagem Simples. A Suécia, também uma líder do movimento internacional, regida pelo

\footnotetext{
${ }^{51}$ A lei paulistana será detalhada na seção 4.5 (“Adoção de Linguagem Simples pelo setor público brasileiro") deste capítulo.

${ }^{52} \mathrm{O}$ Direito Comum é um sistema legal baseado em decisões de tribunais, não em atos legislativos ou executivos - como no caso do Direito Civil -, e por isso dá ênfase ao precedente. Tal contexto resultaria em uma perspectiva voltada para o passado, daí a linguagem jurídica ser mais arcaica e rebuscada, dificultando a leitura de pessoas externas ao sistema legal. Na perspectiva do autor, a escrita excessivamente ornada dos textos do Direito Comum estimularia a busca por parâmetros de escrita mais simples como os que o movimento Plain Language prega.
} 
Direito Civil, seria uma exceção à perspectiva do autor.

As primeiras iniciativas pela simplificação de textos governamentais partiram de dentro da máquina pública britânica e americana durante a Segunda Guerra Mundial. Em comum, o objetivo de agilizar processos, evitar retrabalho e reduzir custos. Isso ocorreu no mesmo momento histórico de popularização das fórmulas de leiturabilidade que Dubay (2004) classifica como clássicas, especialmente o Índice Flesch. Nas décadas seguintes, agentes públicos do Canadá, Austrália e Nova Zelândia iniciaram movimentos semelhantes. O mesmo ocorreu na Suécia, país que acumulava um longo histórico em prol da clareza - no século 18, o rei Carlos XVII já exigia redação mais simples em documentos oficiais. Outras nações europeias replicaram a experiência desses países pioneiros. Nos anos 2000, o movimento Plain Language chegou à América Latina e, no fim dos anos 2010, começou a ganhar fôlego no Brasil.

Estima-se que a comunidade internacional de Linguagem Simples reúna atualmente profissionais que falam 22 idiomas em pelo menos 30 países (PLAIN, s/d; CLARITY; s/d; INTERNATIONAL, s/d). O grupo da Plain Language Association International-PLAIN no LinkedIn tinha 19.881 participantes em fevereiro de 2021 (LINKEDIN, s/d).

\subsection{1.}

\section{Cronologia do movimento internacional: anos 1940-2010}

A seguir, serão listados alguns fatos relevantes das oito décadas do movimento internacional Linguagem Simples. A cronologia tomou por base uma linha do tempo mais compacta que a pesquisadora havia compilado em estudo anterior (FISCHER, 2018), acrescentando marcos que costumam ser referenciados na bibliografia sobre Plain Language.

É importante frisar que a frequência de menções nessa cronologia não é indicativa do peso que a Linguagem Simples ocupa no governo do país. Por exemplo, o Reino Unido, aparece poucas vezes na cronologia, mas é uma das nações em que o uso de Linguagem Simples no setor público é mais consolidado. No caso britânico, a evolução do movimento teve um cunho mais comunitário do que normativo, daí as poucas menções a atos governamentais do país na cronologia. 


\section{ANOS 1940}

- Reino Unido: Em 1940, o primeiro-ministro Winston Churchill emitiu um memorando pedindo que os servidores escrevessem comunicados mais curtos e objetivos (CUTTS, 2013). Em 1946, o escritor George Orwell publicava o ensaio Politics and the English Language (Poitica e a lingua inglesa), denunciando os perigos das falsas erudição e imparcialidade do discurso político camuflado por palavras sem sentido (ORWELL, 1946).

- Estados Unidos: Em 1942, o Congresso aprovou a Lei Federal de Relatórios, considerada o primeiro marco legal da Linguagem Simples naquele país. O objetivo foi "reduzir a burocracia e a excessiva complexidade que o governo impõe às empresas, como, por exemplo, fazer a mesma pergunta em formulários diferentes" (UNITED STATES OF AMERICA, 1942; SCHRIVER, 2017). Em 1944, o funcionário público Maury Maverick registrava a sua insatisfação com o gobbledygook (burocratês) em um memorando interno que ganhou repercussão no jornal Washington Post. (GOBBLEDYGOOK, 1944)

\section{ANOS 1950}

- Reino Unido: No início da década, o servidor Ernest Gowers já havia publicado dois livros por encomenda do Tesouro Britânico para encorajar o funcionalismo a usar um estilo de escrita mais fácil de a população entender. (GOWERS, 1988)

\section{ANOS 1960}

- Estados Unidos: Em 1966, um servidor lotado no órgão responsável pela administração de terras federais divulgou a fórmula que ele próprio havia elaborado para facilitar a escrita de textos de sua repartição. (O’HAYRE, 1966)

\section{ANOS 1970}

- Reino Unido: Em 1975, um comitê instituído pelo primeiro-ministro produziu o Relatório Renton, indicando a linguagem "obscura e complexa" 
como um dos principais problemas a ser combatido na formulação das leis (ZANDEL, 2015). Em 1979, surgiu o movimento da sociedade civil chamado Plain English Campaign (Campanha pelo Inglês Simples), que pressionou o governo britânico a revisar 171 mil formulários públicos. Cerca de 36 mil formulários foram extintos e 58 mil, redesenhados - no final da década de 1980, já era raro encontrar um formulário do governo federal que fosse difícil de entender (CUTTS, 2013). O linguista britânico Tom McArthur afirmou que "em toda a história da linguagem, nunca houve um movimento de base tão poderoso para influenciá-la como a Plain English Campaign” (BBC NEWS, 1997). O grupo transformou-se em uma consultoria de Linguagem Simples que atua na iniciativa privada. Está ativo até hoje.

- Estados Unidos: Em 1971, o Conselho Americano de Professores de Inglês formou um comitê para discutir Public Doublespeak (Linguagem Ambígua de Entes Públicos) ${ }^{53}$. Em 1972, o presidente Richard Nixon decretou que o Federal Register, o Diário Oficial americano, devia ser escrito numa linguagem que qualquer cidadão entendesse. Em 1974, o Congresso aprovou a Lei de Reforma das Pensões, determinando que todos os documentos sobre pensões fossem escritos em Linguagem Simples. Em 1976, a Lei de Redução de Trâmites determinava reduzir o tempo gasto em relatórios e os custos de manutenção de registros. Em 1978, o estado de Nova York foi o primeiro a promulgar uma lei de Plain English. No mesmo ano, uma ordem executiva do presidente Jimmy Carter exigia regulamentações federais em inglês claro e simples, visando reduzir custos operacionais e dificuldades de leitura (SCHRIVER, 2017; PENMAN, 1992).

- Austrália: Em 1973, surgiram as primeiras ações para melhorar a compreensão de leis federais na Austrália (ASPREY, 2010).

\footnotetext{
${ }^{53}$ Definição de doublespeak no Dicionário Collins: "a prática do uso de linguagem ambígua em assuntos políticos, militares ou corporativos, em uma tentativa deliberada de disfarçar a verdade". Em inglês: the practice of using ambiguous language regarding political, military, or corporate matters in a deliberate attempt to disguise the truth.
} 
- Canadá: Em 1976, a Conferência de Harmonização das Leis começou a discutir o uso de Linguagem Simples (ASPREY, 2010).

- Suécia: em 1978, um linguista foi contratado para trabalhar junto ao gabinete do primeiro-ministro, com a missão de modernizar a escrita jurídica de leis e regulamentos (ASPREY, 2010).

\section{ANOS 1980}

- Reino Unido: A expansão do movimento originou a primeira associação reunindo praticantes e ativistas de Linguagem Simples. A associação Clarity foi fundada na Inglaterra em 1983 para promover a clareza em textos jurídicos, recebendo aval do juiz Lord Dennin, importante figura no cenário internacional do Direito Comum. Inicialmente com 28 membros, hoje congrega cerca de 650 pessoas em 30 países (CLARITY, s/d).

- Canadá: Em 1988, era lançado um núcleo dedicado à Linguagem Simples por iniciativa do Canadian Legal Information Centre, com foco em textos jurídicos (SCHRIVER, 1997).

\section{ANOS 1990}

- Estados Unidos: Em 1996, um grupo de servidores públicos começou a se reunir semanalmente na cidade de Washington, formando a rede que hoje se chama Plain Language Action and Information Network. O grupo desenvolveu a primeira versão das diretrizes usadas pelos órgãos federais (Federal Plain Language Guidelines), que vem sendo revisada e atualizada desde então. Naquele mesmo ano, o presidente Bill Clinton emitiu uma Ordem Executiva determinando que os órgãos federais fizessem todo esforço possível para garantir que as regulamentações fossem elaboradas em Linguagem Simples (SCHRIVER, 2017). Al Gore era o vice-presidente de Clinton quando liderou a força-tarefa Parceria Nacional para Reinventar o Governo, que incluía o uso de Plain Language na simplificação da comunicação governamental. Na ocasião, Gore disse a frase que se tornou 
um motto do movimento internacional: "A Linguagem Simples é um direito civil".

- Canadá: Em 1991, o Departamento de Multiculturalidade e Cidadania lançou o guia Plain Language - Clear and Simple para treinar servidores em todos os órgãos federais (MINISTER OF SUPPLY AND SERVICES, 1991). A associação Plain Language Association International-PLAIN foi fundada em 1993, sendo que atualmente reúne cerca de 250 profissionais em 30 países (PLAIN, s/d).

- Suécia: O movimento de Linguagem Simples foi incorporado aos esforços de desburocratização do governo federal (NORD, 2018).

- Austrália: O órgão responsável por elaborar e publicar as leis australianas lançou o Plain English Manual em 1993 (OFFICE OF PARLIAMENTARY COUNSEL, 1993). O guia com diretrizes consolidava o movimento de simplificação iniciado no final dos anos 1980.

- Nova Zelândia: Em 1996, a Law Comission (Comissão de Legislação) publicou um manual para orientar a redação de leis. O relatório indicava o uso de Plain English afirmando que "redatores nunca devem perder a oportunidade de tornar a legislação mais fácil de entender" (LAW COMISSION, 1996).

- União Europeia: O uso de Linguagem Simples passou a ser exigido em atos legais: toda legislação do bloco deveria ter texto claro, simples, conciso e sem ambiguidades, evitando abreviações desnecessárias, jargão e frases excessivamente longas; o guia How to write clearly (Como redigir com clareza) foi publicado em 23 línguas; e a Comissão de Serviços de Tradução organizou uma campanha contra a linguagem pouco compreensível. (ASPREY, 2010)

- África do Sul: A versão em inglês da Constituição de 1996 teve a 
consultoria de especialistas em Plain Language (VILJOEN, 2001).

\section{ANOS 2000}

- Reino Unido: A Casa dos Comuns do Parlamento Britânico instituiu uma comissão para discutir os aspectos alienantes da linguagem usada pela administração pública e por políticos. A investigação gerou o relatório Bad Language: The Use and Abuse of Official Language (Linguagem Ruim: Uso e Abuso de Linguagem Oficial). A comissão conclui ser possível enquadrar a linguagem oficial inexata e complicada em casos de má administração, encorajando a população a reclamar e pedindo que o governo acatasse as queixas com seriedade (HOUSE OF COMMONS, 2009).

- Canadá: Em 2006, o governo federal lançou uma política que exigia o uso de Linguagem Simples em comunicados ao público, em documentos internos e em materiais parlamentares, escritos ou falados. (GOVERNMENT OF CANADA, 2006)

- Suécia: Em 2009, entrou em vigor a Lei da Linguagem. A lei estabeleceuse que a linguagem da administração pública deve ser "culta, simples e compreensível" (NORD, 2018). Em 2020, 81\% dos municípios suecos usavam Linguagem Simples (HANSSON, 2020).

- México: Em 2004, o governo federal lançou o programa chamado Lenguaje Ciudadano (Linguagem Cidadã), hoje inativo. O programa editou um manual intitulado Lenguaje Ciudadano - Un manual para quien escribe en la Administración Pública Federal. (SECRETARIA DE LA FUNCIÓN PÚBLICA, 2004).

\section{ANOS 2010}

- Estados Unidos: O Plain Writing Act (Lei da Redação Simples) foi sancionado em 13 de outubro de 2010 pelo presidente Barack Obama. A lei determinando o uso de Linguagem Simples em todos os órgãos federais resultou da mobilização de servidores públicos junto ao Congresso. O 
objetivo era melhorar a eficácia e a prestação de contas dos órgãos federais, promovendo uma comunicação que o público pudesse entender e usar. A lei definiu redação simples como "uma escrita que é clara, concisa, bemorganizada e que segue outras boas práticas apropriadas ao tema ou ao público a que se destina" (UNITED STATES OF AMERICA, 2010). O cronograma de implementação da lei determinou:

- Seis meses para o governo definir as diretrizes de redação: até lá, os órgãos federais deveriam seguir as orientações da rede de funcionários públicos Plain Language Action and Information Network;

○ Nove meses para cada órgão designar um ou mais funcionários graduados para supervisionar a implementação da lei, treinar equipes, criar uma seção do site em Linguagem Simples e publicar nesta seção um relatório de conformidade com o Plain Writing Act, assinado pelo diretor;

- Máximo de um ano para todos os documentos emitidos pelo órgão serem escritos em Linguagem Simples;

- Máximo de 18 meses para cada órgão publicar no site um relatório de conformidade com o Plain Writing Act assinado por seu diretor e, a partir de então, publicar relatórios anuais.

Na visão de Williams (2015), o Plain Writing Act fez com que órgãos federais dos Estados Unidos priorizassem - pelo menos na internet - o compromisso com a Linguagem Simples. Antes, esse compromisso era mais fragmentado. O 13 de outubro tornou-se tão simbólico que passou a ser considerado Dia Internacional da Linguagem Simples.

- Canadá: Em 2013, a cidade de Calgary instituiu uma Política de Linguagem Simples para todos os textos de programas, comissões, equipamentos e projetos da cidade (THE CITY OF CALGARY, 2013).

- Portugal: A partir de 2011, o Diário da República Eletrônico começou a publicar resumos de leis em Linguagem Clara, suspendendo a publicação de 2013 a 2017, quando voltaram a ser publicados. A produção dos resumos fica a cargo da Imprensa Nacional, órgão subordinado ao Ministério das 
Finanças. (FISCHER, 2019a)

- Colômbia: Em 2013, o presidente Juan Manuel Santos criou a política de Estado Estratégia Lenguaje Claro, como parte do Programa Nacional de Serviço ao Cidadão. Essa política de Estado determina que "toda a informação ao cidadão deve estar em Linguagem Simples” (DNP, 2015). Já foram editados dois manuais com diretrizes de escrita - o Guía de Lenguaje Claro para Servidores Públicos de Colómbia (DEPARTAMENTO NACIONAL DE PLANEACIÓN, 2015) e o guia 10 Pasos de Lenguaje Claro. Um curso virtual capacita servidores e foi desenvolvida uma metodologia para simplificar documentos públicos. As ações de Linguagem Simples são coordenadas pelo Departamento Nacional de Planejamento (DNP). O Banco Interamericano de Desenvolvimento publicou um estudo sobre o impacto da Linguagem Simples na redução dos custos administrativos na Colômbia (CUESTA; REYES; ROSETH, 2019). Em 2018, surgiu a Red de Lenguaje Claro, fruto de parceria entre o Departamento Nacional de Planejamento (DNP), Instituto Caro y Cuervo, Universidade de los Andes, universidade EAFIT. O objetivo da rede é ampliar o alcance dos materiais produzidos para a Estratégia Lenguaje Claro do governo federal (DNP, s/d).

- Peru: Em 2014, o Poder Judicial do Peru publicou o Manual judicial de Lenguaje Claro y Accesible a los Ciudadanos, voltado à comunicação judicial, com foco na redação de sentenças (PODER JUDICIAL, 2014)

- Chile: Em 2017, seis instituições assinaram um acordo de colaboração e formaram a a Red de Lenguaje Claro Chile: Suprema Corte, Câmara dos Deputados, Controladoria Geral da República, Conselho para Transparência, Pontifícia Universidade Católica de Valparaíso e Biblioteca do Congresso Nacional. Os objetivos da rede são: usar Linguagem Simples nos documentos e nas iniciativas de cada instituição; promover e divulgar o uso de Linguagem Simples dentro das instituições; e desenvolver parâmetros para Linguagem Simples e compreensível (RED DE LENGUAJE CLARO CHILE, 2017). 
- Argentina: Em 2017, foi criada a Red Lenguaje Claro, por meio de um convênio estabelecido entre o Senado da Nação, a Secretaría Legal e Técnica da Presidência da República e o Ministério da Justiça e Direitos Humanos. A iniciativa inseriu-se no âmbito do Plano Nacional Anticorrupção (2019 -2023) e um decreto de 2017 relativo a boas práticas em matéria de simplificação. Os objetivos principais são promover o uso de Linguagem Simples em todas as comunicações com os cidadãos e treinar profissionais e equipes governamentais. A rede argentina tem conselhos executivo, diretivo e técnico, além de uma coordenação acadêmica. É aberta a organismos públicos, instituições privadas, redes de instituições e pessoas interessadas no tema. (RED DE LENGUAJE CLARO ARGENTINA, s/d)

A expansão do movimento ao longo dos anos, como se demonstrou nessa linha do tempo, aumentou a produção de conteúdos relacionados à Linguagem Simples. Porém, os materiais que vêm sendo produzidos ficam espalhados, sem integração ou síntese.

Embora o interesse pela Linguagem Simples venha crescendo, a literatura sobre seu desenvolvimento está espalhada por livros, artigos de revistas e periódicos, blogs, listas de discussão, anais de conferências e sites organizacionais. A escassez de publicações que integram o campo acaba nos deixando com muitas conversas, mas sem síntese. Isso também torna difícil acompanhar a trajetória da Linguagem Simples como prática de comunicação e como movimento de comunicação clara ${ }^{54}$. (SCHRIVER, 2017)

O movimento Plain Language no Brasil será comentado na seção 4.5. (“Adoção de Linguagem Simples pelo setor público brasileiro”).

\section{3.}

\section{Técnica de comunicação: de descentralizada a padronizada}

\footnotetext{
${ }^{54}$ Original em inglês: "Although interest in plain language has been on the rise, the literature about its development is scattered across books, magazine and journal articles, blogs, listservs, conference proceedings, and organizational websites. The paucity of publications that integrate the field leaves us with many conversations but no synthesis. That also makes it hard to track the trajectory of plain language as a communication activity and as a movement for clear communication."
} 
Desde o seu início, nos anos 1940, o movimento internacional nunca pactuou algum tipo de normativo que estabelecesse as diretrizes da técnica Linguagem Simples e orientasse a elaboração dos textos. A técnica foi sendo construída de forma diacrônica e assistemática, praticamente sem a participação de linguistas (RODRIGUES, 2013; BECKER, 2016). As diretrizes refletem oito décadas de ações descentralizadas, envolvendo atores sociais de diferentes perfis - servidores públicos, advogados, professores, cidadãos e consumidores, entre outros - em vários países e em vários idiomas.

Nem sempre embasadas em fundamentos teóricos ou pesquisas científicas sobre compreensibilidade textual, as diretrizes foram sendo validadas a partir da prática de quem simplifica os textos no dia a dia. A falta de embasamento teórico suscita críticas da própria comunidade de praticantes (MAZUR, 2000; SCHRIVER; GORDON; 2010) e até chegou a gerar um estudo visando contribuir com a elaboração de diretrizes baseadas em evidências (SCHRIVER, 2014).

As diretrizes da técnica consideram mais do que a redação dos textos. A Linguagem Simples é compreendida como uma atividade multidisciplinar que requer habilidades de escrita, design, empatia e engajamento com públicos excluídos $^{55}$ (SCHRIVER, 2017; PLAIN, s/d). Esse caráter multidisciplinar foi se constituindo à medida que o movimento progredia, e foi sendo gradualmente transferido para as diretrizes.

Inicialmente, a técnica enfatizava os aspectos lexicais e sintáticos - daí as fórmulas de leiturabilidade como o índice Flesch terem tido grande relevância em um primeiro momento e serem até hoje utilizadas como ferramentas auxiliares no diagnóstico de textos (mesmo conhecendo-se as suas limitações).

Entre 1940 e o final dos anos 1970, a maioria dos profissionais da Linguagem Simples enfatizou a reescrita de textos, eliminando frases complexas, usando a voz ativa, escolhendo palavras concretas, tornando as frases mais curtas e substituindo as palavras difíceis por outras mais simples. Na maioria das vezes, os profissionais não se concentraram em características em nível discursivo, como estrutura do texto, coesão e coerência. ${ }^{56}$ (SCHRIVER, 2017)

\footnotetext{
${ }^{55}$ A abordagem multidisciplinar da Linguagem Simples assemelha-se à multidisciplinaridade do Design da Informação, conforme foi discutido no capítulo 2.

56 Original em inglês: Between 1940 and the late 1970s, most plain-language practitioners emphasized rewriting texts by eliminating complex sentences, using the active voice, choosing concrete words, making sentences shorter, and replacing hard words with simpler ones. For the most
} 
Com o passar do tempo e a evolução do movimento, foram sendo agregadas diretrizes relativas a aspectos discursivos, design de documentos e usabilidade.

Redatores profissionais nos anos 1970 começaram a perceber que, quando avaliavam uma comunicação só com base nas poucas características do texto que podiam ser computadas, corriam o risco de pressupor que um texto era claro quando na verdade não era. No final dos anos 1970, o movimento americano de Linguagem Simples daria uma guinada, expandindo a pergunta que começou com: "As pessoas conseguem entender as palavras e frases?" - para perguntar: "As pessoas conseguem realmente compreender e usar toda a comunicação para o que precisam?" (SCHRIVER, 2017)

Mais tarde, em 2008, a crise do mercado financeiro internacional, que Appadurai (2016) classificou como "um fracasso da linguagem”, também impactou a prática da comunicação com clareza. Aspectos éticos foram incorporados ao conjunto de atributos da Linguagem Simples e, consequentemente, somaram-se às diretrizes da técnica.

Os praticantes americanos da Linguagem Simples nos anos 2010 estavam bastante preocupados em saber como seu trabalho poderia ajudar as organizações a combater a erosão da confiança pública ocorrida ao longo das décadas anteriores. Continuaram preocupados com as antigas perguntas ("As pessoas conseguem entender o conteúdo?" "As pessoas conseguem realmente usar o conteúdo?”), mas agora eles também perguntaram: "As pessoas acreditarão no conteúdo? Elas confiam na mensagem? Elas acham que o emissor é honesto?"58 (SCHRIVER, 2017).

Para um aprofundamento sobre a dimensão ética da técnica da Linguagem Simples e para investigar questões relacionadas à confiança que o texto pode ou não inspirar, ver Willerton (2015).

part, they did not focus on discourse-level text features, such as text structure, cohesion, and coherence.

${ }^{57}$ Original em inglês: Professional writers in the 1970s began to realize that when they judged a communication solely on the basis of a few text characteristics that could be counted, they ran the risk of assuming that a text was plain when it was actually quite unclear. By the late 1970s, the American plain-language movement would take a turn, expanding the question it began with - "Can people understand the words and sentences?"- to ask, "Can people actually comprehend and use the whole communication for their intended purposes?"

${ }^{58}$ Original em inglês: American plain-language advocates in the 2010s were very concerned with how their work could help organizations combat the erosion of public trust that had occurred over the previous several decades. Advocates continued to worry over their old questions ('Can people understand the content?' 'Can people actually use the content?'), but now they also asked, 'Will people believe the content? Do they trust the message? Do they think that the messenger is honest?'. 
O estabelecimento descentralizado das diretrizes reflete-se na grande quantidade de guias, livros, posts em sites e redes sociais, e em políticas públicas sobre Linguagem Simples produzidos ao longo do tempo. Há diretrizes que são comuns a todos, tais como usar palavras fáceis do leitor entender, evitar jargão, explicar siglas e simplificar a estrutura das frases. Entretanto, como já colocado, as diretrizes não cobrem apenas aspectos textuais, mas incluem também estrutura e organização da informação, recursos visuais, testes de usabilidade e pressupostos norteadores da conduta de quem emite a mensagem. Para aprender e aplicar a técnica da Linguagem Simples, é recomendável ter uma visão ampla dos conjuntos de diretrizes em circulação. Isso muitas vezes só é possível a partir de sistematizações e sínteses das múltiplas fontes.

Algumas organizações internacionais reconhecidas pela excelência do seu trabalho divulgam na internet as diretrizes de Linguagem Simples que usam. James (2007) e Evans (2011) analisaram as diretrizes de algumas dessas organizações, mas os seus estudos não geraram uma metodologia tornada pública.

Elaborar textos em Linguagem Simples e ensinar a técnica são atividades de consultorias especializadas, que, por razões comerciais, não costumam divulgar as metodologias que criam. São poucos os consultores que publicizam os seus métodos. Entre eles, destaca-se o britânico Martin Cutts, um dos fundadores da Plain English Campaign nos anos 1970. Cutts é autor do livro Oxford Guide to Plain English, principal referência sobre o tema. A obra resulta do longo envolvimento do autor com a causa e do seu trabalho como consultor. $\mathrm{O}$ guia traz a metodologia que Cutts criou. São 25 diretrizes, assim sumarizadas pelo autor:

Estilo e gramática: (1) Ao longo de todo o documento, estabeleça o tamanho médio da frase entre 15 e 20 palavras; (2) Use palavras que seus leitores provavelmente entenderão; (3) Use apenas as palavras que você realmente precisar; (4) Prefira a voz ativa, a menos que haja uma boa razão para usar a passiva; (5) Use verbos claros, nítidos e vivos para expressar as ações em seus documentos, e evite usar cadeias de substantivos; (6) Use listas verticais para quebrar textos complicados; (7) Escreva seus pontos de forma positiva quando puder; (8) Reduza ao mínimo as referências cruzadas; (9) Coloque a pontuação precisa no centro de sua escrita; (10) Lembre-se de que a idade média de leitura da população é de aproximadamente 13 anos; (11) Evite ser escravo de mitos de escrita; (12) Tente evitar linguagem sexista; (13) Use boa gramática - mas sem precisar conhecer centenas de termos gramaticais; (14) Em cartas e e-mails, evite primeiras frases complicadas nos finais de fórmula. Preparação e planejamento: (15) Planeje antes de escrever. Organizando as informações: (16) Organize seu material para que os leitores possam obter as informações importantes no início e navegar facilmente pelo documento; (17) Considere diferentes maneiras de apresentar suas informações. Gerindo a escrita: 
(18) Administre cuidadosamente a redação dos colegas e pense em aumentar a moral e a eficácia deles. Linguagem simples para fins específicos: (19) Cuide do e-mail com tanto cuidado quanto o resto de seus escritos; (20) Dedique um esforço especial para produzir instruções claras e bem organizadas; (21) Não faça rodeios na web dê as principais notícias primeiro e torne o estilo e a estrutura mais precisos; (22) Aplique técnicas de Linguagem Simples a documentos legais como apólices de seguro, contratos de aluguel de carros, leis e testamentos; (23) Para pessoas com baixa alfabetização, corte os detalhes, seja breve e teste seus documentos com os verdadeiros especialistas - os leitores. Layout: (24) Use um layout claro para apresentar suas palavras de maneira facilmente acessível. Revisão de textos: (25) Verifique seu material antes que os leitores o façam. ${ }^{59}$ (CUTTS, 2013)

O caráter descentralizado do movimento internacional, o pouco embasamento teórico das diretrizes e a escassez de sínteses metodológicas talvez expliquem o fato de a técnica ter chegado ao século 21 sem um padrão. Outra justificativa possível é considerar que o estabelecimento de um conjunto de regras fixas contraria a natureza dinâmica da língua, em geral pouco afeita a engessamentos conceituais ou fórmulas únicas, o que explicaria a ausência de normativos para determinar as diretrizes que devem constituir técnica da Linguagem Simples.

Para James (2007), no entanto, a falta de um padrão chancelado por uma autoridade institucional permite que textos pouco claros sejam considerados claros, ameaça a credibilidade de quem atua no setor e impede desenvolver uma certificação para profissionais. Assim sendo, na última década, a comunidade internacional de praticantes decidiu se mobilizar para constituir um parâmetro normativo para a técnica.

\footnotetext{
${ }^{59}$ Original em inglês: Style and grammar: (1) Over the whole document, make the average sentence length 15-20 words; (2) Use words your readers are likely to understand; (3) Use only as many words as you really need; (4) Prefer the active voice unless there is a good reason for using the passive; (5) Use clear, crisp, lively verbs to express the actions in your documents, and avoid using noun strings; (6) Use vertical lists to break up complicated text; (7) Put your points positively when you can; (8) Reduce cross references to a minimum; (9) Put accurate punctuation at the heart of your writing; (10) Remember the population's average reading age is about 13; (11) Avoid being enslaved by writing myths; (12) Try to avoid sexist language; (13) Use good grammar - but you don't need to know hundreds of grammatical terms; (14) In letters and emails, avoid fusty first sentences in formula finishes. Preparing and planning: (15) Plan before you write. Organizing the information: (16) Organize your material so that readers can grasp the important information early and navigate through the document easily; (17) Consider different ways of setting out your information. Management of writing: (18) Manage colleagues' writing carefully and considerately to boost their morale and effectiveness. Plain english for specific purposes: (19) Take as much care with email as you would with the rest of your writing; (20) Devote special effort to producing lucid and well-organized instructions; (21) Don't waffle on the web-put the big news early and make the style and structure punchy; (22) Apply plain-English techniques to legal documents such as insurance policies, car-hire agreements, laws, and wills; (23) For people with low literacy, cut out the fine detail, be brief, and test your documents with the real experts - the readers. Layout: (24) Use clear layout to present your words in an easily accessible way. Proofreading: (25) Check your stuff before the readers do.
} 
Em 2010, a Federação Internacional de Linguagem Simples começou a trabalhar na elaboração do padrão. Mas o projeto só ganhou visibilidade a partir de 2018. No ano seguinte, a federação propôs a International Organization for Standardization-ISO (Organização Internacional para Padronização) o desenvolvimento de um padrão (BALMFORD, 2020). Em fevereiro de 2021, o esboço do normativo havia sido aceito pelo comitê técnico da ISO responsável por terminologias e recursos linguísticos. A etapa seguinte seria submeter o esboço ao comitê geral da entidade.

\section{4.}

\section{Críticas ao movimento e à técnica}

O movimento pela Linguagem Simples vem angariando adeptos desde que surgiu, nos anos 1940. O apelo da causa é forte: confere à compreensibilidade textual o status de direito civil ${ }^{60}$, vê a linguagem como um instrumento promotor de cidadania e propõe transformações com o potencial de melhorar a vida de milhões de pessoas. Tal abordagem vem mobilizando diversos atores sociais, notadamente agentes públicos que se dispõem a empreender as reformas necessárias para ampliar o acesso dos cidadãos a informações, direitos e deveres.

Vozes contrárias à adoção também vêm se manifestando há várias décadas. Na bibliografia em inglês, é comum encontrar o verbo dumb down (baixar o nível de dificuldade e o conteúdo intelectual de alguma coisa) nas argumentações sobre os danos que a simplificação de textos pode causar. As críticas mais recorrentes quanto ao uso da técnica incluem perda de informação, sacrifício da precisão, distorção de sentido, empobrecimento de estilo e infantilização da linguagem. Outra queixa frequente é a falta de embasamento teórico das diretrizes, um ponto que mobiliza os próprios praticantes da técnica, como já foi mencionado neste capítulo.

Além das críticas difusas e, por vezes, anônimas encontradas na bibliografia sobre Linguagem Simples, há também trabalhos de autores que alicerçaram os seus pontos de vista contrários em pesquisas extensas (Penman, 1992; Penamn, 1993;

\footnotetext{
${ }^{60}$ Conforme já foi mencionado na seção 4.2.1. ("Cronologia do movimento internacional: anos 1940-2010”), o vice-presidente americano Al Gore popularizou o motto “A Linguagem Simples é um direito civil".
} 
Barnes 2006; Starck, 2012; Turfler, 2015), notadamente quanto à aplicação da técnica nos campos jurídico e legislativo. Kimble (1995, 2020), uma voz essencial do movimento internacional, tem se dedicado a responder às principais críticas, compilando-as, categorizando-as e fornecendo argumentos para refutá-las. Muitas vezes, os antagonistas da Plain Language são recebidos com uma certa impaciência. Como julgamentos contrários à Linguagem Simples são frequentes e recorrentes, seria de se esperar que pensamentos divergentes fossem acolhidos no intuito de fomentar o necessário debate. $\mathrm{O}$ movimento propõe mudanças sociais estruturais profundas na sociedade que efetivamente requerem a escuta e a integração de diferentes perspectivas.

Uma linha adicional de discordância refere-se à aplicação uniformizada das diretrizes internacionais, sem considerar as características linguísticas de cada idioma. O capítulo 3 mostrou que os elementos linguísticos do burocratês são quase universalizados e, deste modo, seria compreensível que as diretrizes de Linguagem Simples se repetissem nos diferentes idiomas. Entretanto, cabe aqui exemplificar uma crítica cabível no que diz respeito à língua portuguesa. O estudo de Martins et al. (1996) mostrou que palavras em português têm, em média, mais sílabas (2.2) do que a média das palavras em inglês (1.8). Se no nosso idioma são frequentes as palavras mais longas, então a recomendação de preferir palavras curtas deveria ser relativizada na língua portuguesa. Um outro exemplo é a voz passiva:

Embora no inglês a passiva seja reconhecidamente um complexificador, no português ela é muito mais frequente. Temos que ter o cuidado de não dar à passiva o mesmo peso dado a ela pelos classificadores de complexidade textual do inglês. (NILC-METRIX, s/d)

Uma crítica ainda pouco documentada que interessa de forma especial à presente pesquisa diz respeito a leitores proficientes não se beneficiarem com a simplificação do estilo textual. Para essa corrente de opinião, leitores proficientes não apenas têm capacidade cognitiva para processar informações complexas e extensas, processando facilmente textos longos, densos e de complexa estrutura sintática, como até prefeririam a escrita intrincada típica do burocratês. Assim sendo, a Linguagem Simples seria útil somente para públicos com baixo alfabetismo. Tal crítica tem sido recorrente em eventos sobre o uso de Linguagem Simples em governos. A pesquisadora já participou de debates nos quais lhes foram 
dirigidos reiterados questionamentos neste sentido. Observar a repetição do fenômeno em círculos governamentais levou a pesquisadora a formular uma tripla suposição:

1. Agentes públicos não conseguem conceber o burocratês como um problema porque o burocratês lhes é extremamente familiar. Autorreferências dificultam a conexão com pessoas que vivem outras realidades. Eles próprios teriam dificuldade de compreender a informação governamental se o conteúdo não lhes fosse tão familiar.

2. A percepção autorreferenciada de agentes públicos sobre o baixo custo de processamento mental do burocratês pode impactar o avanço de políticas públicas em prol da facilitação da linguagem.

3. Se agentes públicos constatassem que pessoas altamente escolarizadas se desgastam para entender informações governamentais, talvez aumentasse a empatia deles com as dificuldades que a população enfrenta e os normativos em prol da clareza talvez fossem mais disseminados.

Essa tripla suposição contribuiu para determinar o perfil demográfico no estudo experimental da presente pesquisa (adultos com pós-graduação). O experimento será detalhado no capítulo 7.

\section{5.}

\section{Adoção de Linguagem Simples pelo setor público brasileiro}

Conforme o capítulo 3 já mostrou, várias leis federais brasileiras entraram em vigor na última década determinando que informações para cidadãos e consumidores fossem redigidas de forma clara e compreensível. Nenhum desses normativos federais incluiu algum tipo de parâmetro para verificar a compreensibilidade textual exigida, nem indicou diretrizes para a escrita fácil de entender.

Talvez a falta de diretrizes nas leis justifique-se pela existência de dois documentos basilares da redação pública no Brasil, ambos explícitos ao destacar a importância de redigir textos oficiais com clareza: o Manual de Redação da Presidência da República (referência para o poder executivo) e a Lei Complementar $\mathrm{N}^{\circ}$ 95/1998 (referência para o poder legislativo). Ambos surgiram nos anos 1990, 
sendo que o Manual está na terceira edição.

O Manual de Redação da Presidência da República elenca sete atributos da redação oficial, sendo o primeiro deles "clareza e precisão"61. O Manual define o texto claro como aquele imediatamente compreendido pelo leitor, acrescentando que a clareza deve ser uma qualidade básica dos textos oficiais.

Não se concebe que um documento oficial ou um ato normativo de qualquer natureza seja redigido de forma obscura, que dificulte ou impossibilite sua compreensão. A transparência é requisito do próprio Estado de Direito: é inaceitável que um texto oficial ou um ato normativo não seja entendido pelos cidadãos. $\mathrm{O}$ princípio constitucional da publicidade não se esgota na mera publicação do texto, estendendose, ainda, à necessidade de que o texto seja claro. (PRESIDÊNCIA DA REPÚBLICA, 2018)

Para obter clareza, sugere-se dar preferência a palavras simples; explicar siglas; redigir frases curtas, na ordem direta e sem intercalações, entre outras sugestões. Entre as recomendações para precisão, o Manual recomenda a articulação da linguagem comum ou técnica para a perfeita compreensão do texto; o uso das mesmas palavras, evitando sinônimos como recurso estilístico; e a preferência por expressões sem duplo sentido.

A Lei Complementar $\mathrm{N}^{\circ} 95$ é conhecida como a "lei das leis", pois estabelece os padrões para elaboração de todas as leis do país. O artigo $\mathrm{N}^{0} 11$ dispõe sobre os atributos de clareza, precisão e ordem lógica na redação de leis. Com relação à clareza, as recomendações da lei são semelhantes às do Manual da Presidência:

a) usar as palavras e as expressões em seu sentido comum, salvo quando a norma versar sobre assunto técnico, hipótese em que se empregará a nomenclatura própria da área em que se esteja legislando;

b) usar frases curtas e concisas;

c) construir as orações na ordem direta, evitando preciosismo, neologismo e adjetivações dispensáveis;

d) buscar a uniformidade do tempo verbal em todo o texto das normas legais, dando preferência ao tempo presente ou ao futuro simples do presente;

e) usar os recursos de pontuação de forma judiciosa, evitando os abusos de caráter estilístico (BRASIL, 1998)

Quanto à precisão, as recomendações da "lei das leis" são similares às do Manual. Vale aqui destacar "articular a linguagem, técnica ou comum, de modo a

${ }^{61}$ Os demais atributos da redação oficial são: objetividade; concisão; coesão e coerência; impessoalidade; formalidade; padronização; e uso da norma padrão da língua portuguesa. 
ensejar perfeita compreensão do objetivo da lei e a permitir que seu texto evidencie com clareza o conteúdo e o alcance que o legislador pretende dar à norma".

Mesmo com a Lei Complementar No 95 e o Manual da Presidência da República; mesmo havendo legislação recente exigindo clareza; mesmo com o histórico governamental do movimento Plain Language, só nos últimos cinco anos começou-se a discutir Linguagem Simples no setor público brasileiro.

Em 2016, o Governo do Estado de São Paulo lançou o guia Orientações para adoção de linguagem clara, no âmbito de um projeto de boas práticas de governo aberto em cooperação com o Reino Unido (FUNDAÇÃO SEADE, 2016). No mesmo ano, o governo federal lançou a cartilha Fugindo do 'burocratês': como facilitar o acesso do cidadão ao serviço público (GESPÚBLICA, 2016). A cartilha é uma reprodução parcial das diretrizes da rede de funcionários públicos americanos Plain Language Action and Information Network (PLAIN LANGUAGE ACTION AND INFORMATION NETWORK, 2019), acrescida de conteúdo original. $\mathrm{O}$ texto da cartilha brasileira menciona a rede americana, sem explicitar a reprodução parcial do conteúdo. Também não menciona existir um movimento mundial nem informa sobre a existência de uma técnica de comunicação chamada Plain Language, que partilha das mesmas diretrizes ali expostas.

A cartilha Fugindo do 'burocratês' recomenda dezenas de diretrizes. As que se seguem são apenas uma amostra do material. Fazem parte da seção "Escrita":

(1) Seja direto; (2) Seja assertivo; (3) Use a voz ativa; (4) Não tenha receio de usar verbos fortes; (5) Não aumente o seu texto desnecessariamente; (6) Seja cuidadoso na construção de suas sentenças; (7) Use sentenças curtas; (8) Use uma sentença para cada ideia; (9) Não floreie o seu texto; (10) Não use expressões onde uma palavra é suficiente para expor a mesma ideia; (11) Escreva de forma afirmativa; (12) Defina pela regra, não pelas exceções; (13) Deixe condições sempre claras e explícitas; (14 ) Faça uso de exemplos; (15) Seja criativo; (16) Seja responsável; (17) Tenha cuidado com o uso de ferramentas de ênfase (GESPÚBLICA, 2016).

A cartilha foi publicada no âmbito do Programa Nacional de Gestão Pública e Desburocratização, extinto em 2017. O conteúdo da cartilha é atualmente usado no Guia de Edição de Serviços do portal do governo federal chamado Gov.br. Esse guia será comentado no capítulo 6.

Em 2018, foi lançado o livro Clareza em textos de e-gov, uma questão de cidadania (FISCHER, 2018), a primeira sistematização sobre Linguagem Simples 
- movimento e técnica - em língua portuguesa. A obra contribuiu para fomentar discussões sobre o uso de Linguagem Simples no setor público brasileiro ( $3^{\circ}$ ENCONTRO, 2018; ENCONTRO, 2019; FISCHER, 2019b).

Em novembro de 2019, a Prefeitura de São Paulo lançou o Programa Municipal de Linguagem Simples, por meio de um decreto (PREFEITURA, 2019). O programa inclui oficinas de capacitação de servidores, oficinas de simplificação de documentos e materiais de apoio. A execução ficou a cargo do (011).lab, Laboratório de Inovação em Governo, ligado à Secretaria de Inovação e Tecnologia. O programa veio a ser regulamentado por lei em março de 2020 (SÃO PAULO, 2020), passando a se chamar Política Municipal de Linguagem Simples $\mathrm{O}$ artigo $4^{\circ}$ da lei paulistana determina o uso das seguintes diretrizes:

(1) Conhecer e testar a linguagem com o público-alvo; (2) Usar linguagem respeitosa, amigável, simples e de fácil compreensão; (3) Usar palavras comuns e que as pessoas entendam com facilidade; (4) Não usar termos discriminatórios; (5) Usar linguagem adequada às pessoas com deficiência; (6) Evitar o uso de jargões e palavras estrangeiras; (7) Evitar o uso de termos técnicos e explicá-los quando necessário; (8) Evitar o uso de siglas desconhecidas; (9) Reduzir comunicação duplicada e desnecessária; (10) Usar elementos não textuais, como imagens, tabelas e gráficos de forma complementar. (SÃO PAULO, 2020)

Em dezembro de 2019, foi apresentado na Câmara dos Deputados um projeto de lei nos mesmos moldes da legislação paulistana (CÂMARA DOS DEPUTADOS, 2019). Em fevereiro de 2021, o projeto estava aguardando apreciação da Comissão de Trabalho, Administração e Serviço Público há doze meses.

O Governo do Estado do Ceará começou a estruturar um programa de Linguagem Simples em dezembro de 2019. O objetivo é formar servidores, apoiar e estimular iniciativas de simplificação da linguagem em documentos e projetos do estado, especialmente na área de saúde pública. A execução do programa está a cargo do Íris - Laboratório de Inovação e Dados, ligado à Casa Civil.

Durante o ano de 2020, foram realizados encontros e oficinas sobre Linguagem Simples no setor público (WEBINÁRIO, 2020; ÍRIS, 2020; SEMANA DE INOVAÇÃO, 2020). Em março de 2021, foi lançada uma rede nacional de Linguagem Simples organizada por servidores públicos dos laboratórios de inovação Íris, do Governo do Ceará, e (011), da Prefeitura de São Paulo, e Secretaria de Governo Digital do Ministério da Economia. O objetivo da rede é 
conectar servidores públicos dos âmbitos municipal, estadual e federal. A pesquisadora desta dissertação fez parte do grupo fundador da rede, integrando o comitê gestor.

Por fim, vale destacar que a lei municipal de Linguagem Simples em São Paulo e o projeto de lei em tramitação na Câmara dos Deputados tendem a impulsionar iniciativas semelhantes em outras casas legislativas. Em dezembro de 2020, um projeto de lei idêntico ao paulistano havia sido aprovado pela Câmara de Vereadores de São Carlos (SP) e aguardava a sanção do prefeito (PROJETO, 2020).

\section{6.}

\section{Síntese do capítulo 4}

O capítulo mostrou a natureza múltipla da Linguagem Simples. Na terminologia, apresenta-se aos pares: Linguagem Simples e Linguagem Clara, Plain Language e Plain English, Lenguaje Claro e Lenguaje Simple. Como movimento social, desdobrou-se por vários países e alcança os três poderes. Como técnica de comunicação, exige habilidades multidisciplinares além da escrita.

Há oito décadas o movimento internacional dá contornos cívicos à compreensibilidade textual: defende o direito de cidadãos e consumidores entenderem as informações que orientam o dia a dia. Prega o uso de um estilo de escrita simples, direto e objetivo como alternativa aos elementos linguísticos incompreensíveis do burocratês. A cronologia destacou iniciativas voltadas à simplificação de textos governamentais em diversos países, desde o memorando de Winston Churcill pedindo brevidade na escrita dos servidores britânicos durante a Segunda Guerra Mundial até a recente formação de redes de Linguagem Simples na América Latina. As etapas de implantação do Plain Writing Act (Lei da Redação Clara) dos Estados Unidos foram detalhadas.

O movimento internacional pulverizado resultou no desenvolvimento diacrônico e assistemático da técnica de comunicação. A técnica começou enfatizando aspectos lexicais e sintáticos, depois agregando aspectos discursivos, design de documentos, usabilidade e noções éticas.

O capítulo também mostrou que a Linguagem Simples carece de sínteses. Há muito material, mas pouca integração. A federação internacional vem fazendo 
esforços neste sentido. $\mathrm{O}$ principal esforço é recente e visa constituir um padrão internacional da técnica Linguagem Simples que seja normatizado pela International Organization for Standardization-ISSO. Foram comentadas algumas críticas que a Linguagem Simples costuma receber, destacando-se a carência de espaços para acolher opiniões divergentes e fomentar a reflexão. Foi apresentado como alguns entes públicos brasileiros vêm implementando ações de Linguagem Simples: Governo do Estado de São Paulo, governo federal, Prefeitura de São Paulo, Câmara dos Deputados e Governo do Estado do Ceará, além de casas legislativas.

Os tópicos da compreensibilidade textual e da Linguagem Simples no setor governamental serão aprofundados no próximo capítulo, que é dedicado à digitalização de serviços e informações do setor público no Brasil e no mundo. 


\section{Governo eletrônico (e-gov)}

Este capítulo aborda a prestação de informações e serviços no setor público no meio digital (governo eletrônico, ou e-gov), com foco no governo federal brasileiro. Reúne conceitos e informações que contribuem para examinar o papel do texto fácil de entender no uso de serviços públicos digitais. Considera as perspectivas de compreensibilidade textual, burocratês e Linguagem Simples que já foram discutidas nos capítulos 2,3 e 4, respectivamente. Conclui a fundamentação teórica que irá alicerçou o levantamento documental e o estudo experimental que serão relatados nos capítulos seguintes.

O presente capítulo começará com a definição de termos-chave e com um comentário sobre a reengenharia de processos ser um pressuposto da digitalização dos governos. A seguir, discutirá vantagens, barreiras e habilidades inerentes à governança digital. Quanto ao governo federal brasileiro, apresentará: a política norteadora de e-gov vigente; o estágio de digitalização dos serviços públicos e aspectos da digitalização na Previdência Social, especificamente quanto ao atendimento do Instituto Nacional de Seguro Social (INSS); e também apresentará normativos que exigem informação fácil de entender no governo eletrônico brasileiro. Depois, verificará como a Linguagem Simples é recomendada em portais nacionais de serviço em diversos países. O capítulo terminará condensando os principais conceitos aqui discutidos.

\section{1.}

\section{Definição de termos}

Transformação digital de governos - A definição da Organização das Nações Unidas (ONU) mostra que o processo de transformação vai além do uso de tecnologias digitais. A ONU recomenda uma abordagem holística, que seja 
inclusiva, que priorize as pessoas e reduza riscos.

Transformação digital de governos pode ser definida como o processo de transformar modelos de governança e mecanismos de interação entre governo e sociedade e de inovar na formulação de políticas, organizações, serviços e programas governamentais, mediante a potencialização de tecnologias digitais. Refere-se a um processo fundamental de mudanças que requer abordagem holística, pondo as pessoas em primeiro lugar, e gira em torno das necessidades dos indivíduos, incluindo os mais excluídos, e da mitigação dos riscos associados ao uso de tecnologias (...) A característica central de uma abordagem holística da transformação digital de governos é o alinhamento de instituições, organizações, pessoas, tecnologia, dados e recursos para apoiar a mudança desejada dentro e fora do setor público para gerar valor público (...) Deve ser inclusiva e garantir que qualquer transformação tenha como objetivo criar oportunidades iguais para que todas as pessoas tenham acessos a serviços confiáveis e de qualidade (...) Deve também ser informada por enfoques para prestar serviços e gerir programas centrados nas pessoas, abordando problemas concretos e necessidades dos diferentes grupos na sociedade ${ }^{62}$. (UNITED NATIONS, 2020, p. 180)

\section{A primeira versão da Estratégia de Governança Digital do Brasil já enfatizava}

o caráter social do processo e a importância de superar as barreiras digitais:

O desafio da transformação digital não é tecnológico. O maior desafio é direcionar esforços e coordenar mudanças estruturais na organização da sociedade e do governo, preparando-os para enfrentar as barreiras e, principalmente, aproveitar as oportunidades de uma economia digital. (BRASIL, 2018)

Governo eletrônico (e-gov) - Adoção e o uso das tecnologias de informação e comunicação na administração pública para a prestação de informações e de serviços. O conceito surgiu no final dos anos 1990, com o avanço da internet e das novas possibilidades de administrar a máquina pública sem a necessidade do encontro físico entre servidores e cidadãos. Hoje, governo eletrônico abrange

\footnotetext{
${ }^{62}$ Original em inglês: Digital government transformation can be defined as the process of transforming governance models and interaction mechanisms between government and society and innovating government policymaking, organizations, services and programmes by leveraging digital technologies. It refers to a process of fundamental change requiring a holistic approach that puts people first and revolves around the needs of individuals, including those left furthest behind, and the mitigation of risks associated with the use of technologies.(..) The central feature of a holistic approach to digital government transformation is the alignment of institutions, organizations, people, technology, data, and resources to support desired change within and outside of the public sector for the generation of public value (...) It should be inclusive and ensure that any transformation is aimed at creating equal opportunities for all people to access reliable and quality services.(...) It should also be informed by people-centric approaches to service delivery and programme management, addressing concrete problems and needs experienced by different groups in society.
} 
websites, aplicativos para celular, redes sociais, aplicativos de mensagens instantâneas, Big Data, Inteligência Artificial, robótica, bots, drones e computação quântica, entre outras tecnologias (UNITED NATIONS, 2018, p.xxvii). Governo digital e governança digital são sinônimos.

A administração pública federal do Brasil começou usando o termo governo eletrônico e, em 2015, passou a usar o termo governança digital. A mudança foi justificada como uma "evolução do paradigma". Eis a definição do governo brasileiro para governança digital:

Utilização, pelo setor público, de tecnologias da informação e comunicação com o objetivo de melhorar a informação e a prestação de serviços, incentivando a participação dos cidadãos no processo de tomada de decisão e tornando o governo mais responsável, transparente e eficaz. (BRASIL, 2016)

Como a ONU e o Comitê Gestor da Internet no Brasil usam o termo governo eletrônico, a presente pesquisa também usa esse termo.

Trâmite burocrático - Terminologia indicada pelo Banco Interamericano de Desenvolvimento (BID), é um sinônimo para serviço público transacional. A função básica de um trâmite burocrático é conectar pessoas e empresas aos serviços e obrigações do governo. O BID propõe a seguinte definição:

\begin{abstract}
Conjunto de requisitos, etapas ou ações através das quais indivíduos ou empresas podem pedir ou fornecer informações a órgãos públicos, com o objetivo de obter um direito - um registro, o acesso a um serviço, uma permissão - ou para cumprir uma obrigação. Alguns trâmites dão acesso a direitos de todos os cidadãos de um país, como documento de identidade ou certidão de nascimento. Outros podem ser acessados somente por quem atende certas condições. (...) Alguns trâmites são fornecidos pelo Estado gratuitamente, outros exigem que se pague uma taxa. Eles implicam em custos de transação (alguns mais do que outros), mas cumprem uma série de funções que são cruciais para proporcionar direitos e garantir o cumprimento das obrigações. Os trâmites burocráticos podem ser agrupados em quatro categorias: registro, certificação e verificação; obrigações; serviços; e permissões. ${ }^{63}$ (ROSETH, REYES E SANTISO, 2018b, p.36).
\end{abstract}

\footnotetext{
${ }^{63}$ Original em inglês: Government transactions - Set of requirements, steps, or actions through which individuals or firms can demand information from, or provide it to, a public entity, with the aim of obtaining a right - a registration, access to a service, a permit-or to fulfill an obligation. Some government transactions provide access to the rights of all citizens of a country, such as possessing an identity document or a birth certificate. Others can be accessed only by those who satisfy certain characteristics (...) Some transactions are provided by the state free of charge, whereas others require a fee to be paid. They imply transaction costs (some more than others), but they fulfill a series of functions that are crucial for providing rights and ensuring that obligations
} 
E-serviços - Digitalização dos trâmites burocráticos que constituem a categoria "serviços". Quando digitalizados, os serviços públicos passam a ser chamados de e-serviços. A digitalização de serviços é um processo-chave para o desenvolvimento de governos eletrônicos.

Governos eletrônicos pressupõem o autoatendimento como a forma prioritária de prestar serviços públicos em meio digital. A primeira política de governança digital do Brasil dizia que "o autosserviço será a forma prioritária de prestação de serviços públicos disponibilizados em meio digital" (BRASIL, 2016).

$\mathrm{O}$ autoatendimento reduz ou elimina os canais de atendimento presencial, pois a meta é que o maior número possível de serviços seja processado pelos cidadãos em seus celulares ou computadores, sem requerer qualquer tipo de intermediação humana. Neste contexto, é preciso minimizar dúvidas, pois as possibilidades de esclarecimento são limitadas.

\section{2.}

\section{Reengenharia de serviços anterior à digitalização}

O termo governo eletrônico popularizou-se em 1997, quando os Estados Unidos lançaram o primeiro plano de "reengenharia por meio da tecnologia da informação" no setor público. O plano desaconselhava a mera digitalização de trâmites "antigos e desgastados". Em governo eletrônico, os trâmites deveriam ser reinventados, "repensando como o governo trabalha e como atende os cidadãos" (GORE, 1997). Desde então, e-gov ficou associado a redesenhar e simplificar processos.

A Organização das Nações Unidas (ONU) alerta que governo eletrônico não é um fim, mas "um meio para melhorar a prestação de serviços públicos; ampliar engajamento, transparência, responsabilidade e inclusão - em última instância, tornar a vida melhor para todos"64 (UNITED NATIONS, 2020). Daí a adesão de países e cidades estar sendo ampla e veloz.

are met. Government transactions can be grouped into four general categories: registration, certification, and verification; obligations; services; and permits.

${ }^{64}$ Original em inglês: Digital government is not an end; it is a means to improving public service delivery, increasing people's engagement, enhancing transparency, accountability and inclusion, and ultimately making life better for all. 
O Índice de Desenvolvimento de Governo Eletrônico da ONU usa três componentes (serviços online, infraestrutura de telecomunicações e capital humano) para ranquear o estágio de digitalização dos 193 países-membros. O ranking mede o desenvolvimento de e-gov em "muito alto", "alto", "médio" e "baixo". No Índice de 2020, 29\% dos países estavam no nível "muito alto" inclusive o Brasil, na 54 ${ }^{\text {a }}$ posição ${ }^{65}$ (UNITED NATIONS, 2020).

Ocorre que, mesmo em países do topo do ranking, a reengenharia e a simplificação de processos anterior à digitalização ainda não foi totalmente assimilada. É o caso do governo federal brasileiro, que só "às vezes" simplifica trâmites antigos antes de digitalizá-los (ROSETH, REYES E SANTISO, 2018b, p.145). Tal inconstância talvez seja fruto da alta complexidade regulatória do país, que exige inúmeros procedimentos para o mesmo trâmite. Há ainda o alto nível de desconfiança de governos para com cidadãos e servidores, que resulta em privilegiar proteção em detrimento da experiência dos usuários (ROSETH, REYES E SANTISO, 2018b, pg.84-88).

Redesenhar processos em e-gov envolve remover obstáculos. Há muitas evidências sobre o estilo textual ser um desses obstáculos. Se o burocratês, usado por default no setor público, dificulta a compreensão das informações (capítulo 3), o movimento Plain Language acumula oito décadas de experiência de remoção de obstáculos linguísticos em textos governamentais (capítulo 4). Ainda assim, a maioria das informações de e-gov continua sendo disponibilizada em burocratês.

\section{3.}

\section{Vantagens, barreiras à interação e habilidades necessárias aos cidadãos}

Governos eletrônicos operam em pólos contraditórios. Por um lado, promovem benefícios à sociedade e aos cofres públicos, agilizando o contato de cidadãos e empresas com órgãos governamentais. Por outro lado, exigem

\footnotetext{
${ }^{65}$ Em 2018, o Brasil ocupava uma posição mais alta, a 44a . Mesmo tendo caído no ranking, o país segue em trajetória de progresso. "A posição relativa de um país no ranking de desenvolvimento do governo eletrônico pode flutuar com o tempo devido a mudanças globais e a mudanças no ranking de outros países no mesmo campo" (UNITED NATIONS, 2020).
} 
equipamentos e conhecimentos inacessíveis a muitos, agravando a desigualdade social e a exclusão digital ${ }^{66}$. Tal cenário requer políticas promotoras de habilidades que são essenciais à plena cidadania digital.

Vantagens - Plataformas de e-gov eliminam ou reduzem problemas que são recorrentes na prestação de serviços presenciais, especialmente gasto de tempo, corrupção e custo. $\mathrm{O}$ meio digital reduz o gasto de tempo com atendimentos pois não é necessário se deslocar, não existem filas, não há distribuição de senhas e nem morosidade de servidores. O governo federal estima que a digitalização de 500 serviços públicos em 2019 eliminou 146 milhões de horas de deslocamento dos cidadãos (GOV.BR, s/d).

$\mathrm{O}$ atendimento em e-gov é direto, rápido (se a conexão ajudar e o cidadão souber o que fazer) e impessoal. A impessoalidade favorece a redução da corrupção, pois o trâmite digital é o mesmo para todos. Baseia-se em regras e pode ser rastreado, limitando a possibilidade de suborno ou "jeitinhos" em troca de tratamento preferencial. Um estudo da Transparência Internacional feito em 2017 apontou que $29 \%$ dos latino-americanos afirmaram ter pago propina ao acessar um serviço público presencial no último ano - o equivalente a mais de 90 milhões de pessoas na região (ROSETH; REYES; SANTISO, 2018a, p.6). Tecnologias de ponta como blockchain ajudam a reduzir riscos de falsificação ou modificação ilegal de documentos, (ROSETH; REYES; SANTISO, 2018b, p. 105).

Quanto aos custos, digitalizar a oferta de serviços e informações traz uma economia significativa. Transações virtuais entre governos e cidadãos podem custar até 50 vezes menos do que as transações presenciais (UNITED NATIONS, 2018, p. 29). O governo federal brasileiro calcula que o custo médio de atendimento presencial em seus órgãos saia por $\mathrm{R} \$ 43,68$, enquanto o atendimento online pode chegar a R\$ 1,20. Ou seja, os cofres públicos economizam mais de 97\% por transação (MINISTÉRIO DA CIÊNCIA, TECNOLOGIA, INOVAÇÕES E COMUNICAÇÕES, 2018, p. 95). Só a digitalização de 500 serviços públicos federais em 2019 teria economizado R\$ 345 milhões (GOV.BR, s/d).

\footnotetext{
${ }^{66}$ Exclusão digital: Tradução do termo em inglês digital divide. O Banco Interamericano de Desenvolvimento (BID) prefere a tradução "brecha digital", em vez de "exclusão digital"que esta pesquisa adota.
} 
Barreiras à interação - $\mathrm{O}$ autoatendimento online dos cidadãos reduz a lentidão e os custos, promove transparência e inibe a corrupção. Mas também agrava a exclusão digital, dificultando ou impedindo o acesso de quem é pouco ou nada conectado, principalmente os mais vulneráveis. De início, exclusão digital relacionava-se à falta de acesso à internet e a computadores. O avanço da tecnologia adicionou fatores como velocidade de conexão, qualidade dos equipamentos e alfabetização digital.

Exclusão digital e exclusão social estão intrinsecamente relacionadas. Pesquisas mostram que o acesso diferenciado à tecnologia contribui para a estratificação ou inclusão socioeconômica (UNITED NATIONS, 2018, p.27). Esse é um problema global e multifacetado, que agrava as profundas desigualdades sociais que sempre caracterizaram o Brasil.

\begin{abstract}
Apesar do avanço na oferta de serviços de governo eletrônico, as parcelas mais vulneráveis da população - justamente as que poderiam ser beneficiadas fortemente com o acesso on-line a serviços públicos relacionados a direitos e ao bem-estar tiveram menor acesso a eles. Menos da metade dos usuários de Internet com escolaridade até Educação Infantil (30\%), com Ensino Fundamental (46\%) e pertencentes às classes D e E (48\%) utilizaram a rede para buscar informações ou realizar serviços públicos (NÚCLEO DE INFORMAÇÃO E COORDENAÇÃO DO PONTO BR, 2020b, p. 76)
\end{abstract}

A gravidade do contexto brasileiro veio à tona em 2020, quando a pandemia da Covid-19 obrigou a suspensão de atendimentos presenciais em órgãos públicos. $\mathrm{O}$ atendimento exclusivo por meio digital dificultou ou impediu o acesso de milhões de pessoas a serviços e benefícios. Dificuldade ao usar o aplicativo da Caixa Econômica Federal foi o motivo mais citado por usuários de internet que não conseguiram receber o auxílio emergencial do governo federal (NÚCLEO DE INFORMAÇÃO E COORDENAÇÃO DO PONTO BR, 2020b, p. 77). O episódio mostrou o vulto da vulnerabilidade digital no Brasil.

A Organização das Nações Unidas esquematiza treze categorias de barreiras que prejudicam o acesso da população aos trâmites digitais. Além das tecnológicas, a lista inclui barreiras geográficas (localização em áreas rurais ou remotas com qualidade de conexão ruim); barreiras de idade (os idosos são os mais prejudicados pela falta de competências digitais); e mesmo barreiras de idioma nos países que falam várias línguas mas só disponibilizam serviços públicos na língua oficial (UNITED NATIONS, 2018, p. 34). A ONU considera essa categorização apenas 
uma esquematização inicial e estimula a comunidade internacional a expandir a lista de barreiras. Há décadas, o movimento internacional Plain Language considera a linguagem burocrática do setor público como uma barreira que dificulta o acesso a informações de interesse público, conforme já visto no capítulo 4 . O Banco Interamericano de Desenvolvimento também considera a linguagem difícil de entender como um fator segregador:

Informações complexas e difíceis de acessar sobre os requisitos e as especificações dos trâmites, formulários que são difíceis de preencher ou têm linguagem difícil de entender são fatores que também afetam, em maior grau, pessoas com baixo nível de escolaridade, que não têm as devidas ferramentas para navegar no sistema. Isto pode aumentar as chances de desistirem de reivindicar seus direitos, ou pagarem para ter ajuda com seus formulários ${ }^{67}$. (ROSETH, REYES E SANTISO, 2018b, p. 67).

Pedraza (2017) defende que a técnica da Linguagem Simples faça parte das políticas para superar as barreiras no acesso a instituições públicas. A pesquisadora colombiana lembra que reconhecer as necessidades comunicativas dos cidadãos aumenta o grau de confiança no Estado.

Habilidades necessárias aos cidadãos - Uma das principais promessas da governança digital é equalizar o acesso a serviços, benefícios e obrigações que vêm sendo historicamente privados aos grupos mais vulneráveis. Porém, como já visto, as barreiras ao acesso são inúmeras e sobrepostas. Para Melchiori (2020, p. 141), "na ausência de políticas públicas que levem em consideração a realidade dos beneficiários na sua implementação, a digitalização pode acabar por agravar desigualdades estruturais existentes na sociedade off-line”.

A ONU frisa que e-govs existem para contribuir com os objetivos da Agenda 2030 para o Desenvolvimento Sustentável ${ }^{68}$, que tem por motto a frase "Ninguém deve ser deixado para trás" e organiza-se em torno de 17 objetivos.

\footnotetext{
${ }^{67}$ Original em inglês: The complex, hard-to-access information on transaction requirements and specifications, forms that are difficult to fill out, or that are presented in a language hard to understand are factors that also affect, to a greater extent, people with lower educational attainment, who lack the necessary tools to navigate the system. This can make it more likely that they give up on their attempts to claim their rights, or that they hire private help for assistance with their forms.

${ }^{68}$ Os Objetivos de Desenvolvimento Sustentável foram pactuados pelos países-membro da ONU em 2015. Trata-se de um apelo à ação global para acabar com a pobreza, proteger o meio ambiente e o clima, garantir paz e prosperidade às pessoas. O documento estabelece 17 objetivos e 169 metas a serem alcançados até o ano 2030 (NAÇÕES UNIDAS BRASIL, s/d).
} 
Governo eletrônico não é somente a mera prestação de serviços; também desempenha um papel no fortalecimento da alfabetização digital (Objetivo 4) ${ }^{69}$, inclusão digital (Objetivos 5,8 e 10$)^{70}$, conectividade digital (Objetivo $9^{71}$ ) e identidade digital (Objetivo 16). ${ }^{72}$ (UNITED NATIONS, 2020, p. xxiii).

Assim sendo, é esperado haver o que Pedraza (2017, p. 9) chama de “exercício pedagógico do Estado" para desenvolver as habilidades requeridas pela cidadania digital que são pré-requisito para acessar as plataformas de e-gov. Entre tais habilidades, destacam-se:

- Alfabetização ou letramento digital - Competência para entender e operar as tecnologias de informação e comunicação (TICs), tais como celulares, computadores, aplicativos, mecanismos de busca e navegadores. O Banco Interamericano de Desenvolvimento (BID) alerta que, sem tal competência, os cidadãos não conseguem usufruir dos serviços digitais, pois o autoatendimento online requer habilidades que vão além do básico (ROSETH, REYES E SANTISO, 2018b, p. 132). Entre outras ações, é preciso aprender a usar email, criar login e senha ou ler aquivos em pdf (PEDRAZA, 2017).

- Alfabetização ou letramento governamental - "Educar os cidadãos sobre o trabalho da administração e sobre a relação direta com o usuário, que percebe as instituições com distanciamento e as considera ineficientes"73 (PEDRAZA, 2017, p. 9). Essa habilidade é fundamental para a eficiência do autoatendimento em plataformas digitais. O BID recomenda que programas de treinamento no uso de serviços públicos online sejam complementares aos programas de alfabetização digital. (ROSETH;

\footnotetext{
${ }^{69}$ Objetivo 4: Assegurar a educação inclusiva e equitativa e de qualidade, e promover oportunidades de aprendizagem ao longo da vida para todos (ibid, s/d).

70 Objetivo 5: Alcançar a igualdade de gênero e empoderar todas as mulheres e meninas. Objetivo 8: Promover o crescimento econômico sustentado, inclusivo e sustentável, emprego pleno e produtivo e trabalho decente para todos. Objetivo 10: Reduzir a desigualdade dentro dos países e entre eles. (ibid, s/d).

71 Objetivo 9: Construir infraestruturas resilientes, promover a industrialização inclusiva e sustentável e fomentar a inovação (ibid, s/d).

${ }^{72}$ Objetivo 16: Promover sociedades pacíficas e inclusivas para o desenvolvimento sustentável, proporcionar o acesso à justiça para todos e construir instituições eficazes, responsáveis e inclusivas em todos os níveis (ibid, s/d).

73 Original em espanhol: Instruir a los ciudadanos en lo que respecta al quehacer de la administración y su relación directa con el usuário, quien percibe la labor de las instituciones con distanciamiento y la considera ineficiente.
} 
REYES; SANTISO, 2018b, p. 132).

Considere-se ainda que a plena interação em e-gov requer cidadãos com letramento em leitura digital, a habilidade para ler, navegar e avaliar a confiabilidade de informações na internet.

\section{4 .}

\section{Governo eletrônico no Brasil}

A digitalização do setor público no Brasil vem avançando rápido. A pesquisa TIC Governo Eletrônico 2019 informa haver 95\% dos órgãos municipais, estaduais e federais com website ou página oficial na internet - no caso dos órgãos federais, o percentual chega a 100\%. (NÚCLEO DE INFORMAÇÃO E COORDENAÇÃO DO PONTO BR, 2020a).

A pesquisa TIC Domicílios 2019 (NÚCLEO DE INFORMAÇÃO E COORDENAÇÃO DO PONTO BR, 2020b) indica que 68\% dos usuários brasileiros de internet com 16 anos ou mais buscaram informações ou realizaram serviços de governo eletrônico nos doze meses anteriores à pesquisa. Os serviços públicos on-line mais acessados em 2019 foram os referentes aos direitos do trabalhador ou previdência social (36\%), impostos e taxas governamentais (28\%) e documentos pessoais (28\%). Entretanto, na maior parte dos casos, os usuários de internet apenas buscaram informações sobre os serviços. Só $10 \%$ realizaram os trâmites de forma totalmente digital, sem precisar ir a um posto de atendimento. Os motivos mais citados para os usuários de internet não usarem o autoatendimento online de órgãos públicos foi preferir atendimento pessoal (72\%), não precisar dos serviços $(57 \%)$ e achar que o contato com o governo pela Internet é complicado $(55 \%)$.

A pesquisa observa ter havido um crescimento da proporção de pessoas que não interagiram com governo eletrônico por considerarem difícil encontrar os serviços que precisavam: de 25\% em 2017 para 33\% em 2019.

\subsection{1.}

\section{Política norteadora vigente}


Desde 2000, ano de instituição do primeiro grupo de trabalho em governo eletrônico no poder executivo federal, existem políticas que orientam o desenvolvimento de e-gov no Brasil. Em 2016, foi lançada a Estratégia de Governança Digital (BRASIL, 2016). O documento foi revisto dois anos depois para alinhar-se à Estratégia Brasileira para a Transformação Digital-E-Digital, que é um plano de longo prazo para a economia digital (MINISTÉRIO DA CIÊNCIA, TECNOLOGIA, INOVAÇÕES E COMUNICAÇÕES, 2018).

Em 2019, a Estratégia de Governança Digital era concluída com 53\% dos serviços federais digitalizados. No ano seguinte, um decreto presidencial instituiu a Política de Governo Digital (BRASIL, 2020), determinando as prioridades da transformação digital da administração federal e instituindo a Estratégia de Governo Digital 2020-2022. Atualmente vigente, a Estratégia organiza-se em seis princípios, dezoito objetivos e várias iniciativas associadas a cada objetivo.

Os seis princípios que atualmente norteiam o governo digital brasileiro são: Centrado no cidadão, Integrado, Inteligente, Confiável, Transparente e Aberto, e Eficiente. Ao escopo desta dissertação, interessa destacar o primeiro princípio, Centrado no cidadão, que é assim apresentado:

\begin{abstract}
Um governo centrado no cidadão preocupa-se em oferecer uma jornada mais agradável a ele, respondendo às suas expectativas por meio de serviços de alta qualidade (simples, ágeis e personalizados) e mantendo-se atento à sua experiência. (...) Dentro deste propósito, tendo sempre o cidadão no foco das decisões sobre políticas e serviços ofertados, esse princípio estabelece objetivos e iniciativas que levarão à transformação do Estado em um provedor de serviços que busca constantemente entender as necessidades dos usuários de serviços e ofereça valor e uma boa experiência de uso para os cidadãos e organizações da sociedade.
\end{abstract}

(GOVERNO DIGITAL, s/d)

Quanto aos dezoito objetivos da Estratégia de Governo Digital, ao escopo desta pesquisa interessam o Objetivo 1-Oferta de serviços públicos digitais e a iniciativa 1.1. a ele associada ("transformar todas as etapas e os serviços públicos digitalizáveis até 2022”); e também o Objetivo 2-Avaliação de satisfação nos serviços digitais e a a iniciativa 2.3 a ele associada ("aprimorar a percepção de utilidade das informações dos serviços no portal único gov.br e atingir, no mínimo, $75 \%$ de avaliações positivas até 2022”).

A implementação de políticas norteadoras é de grande importância, porém deve-se observar que a transformação digital exige grandes mudanças culturais. 
Neste sentido, a Organização das Nações Unidas observa que "mudar mentalidades, incluindo crenças e atitudes, é um dos desafios mais difíceis na implementação de uma estratégia governamental digital". ${ }^{74}$ (UNITED NATIONS, 2020, p.198)

\subsection{2.}

\section{Serviços públicos federais: estágio de digitalização}

Ainda que a maioria dos serviços públicos brasileiros seja fornecida por estados e municípios (OECD, 2018, p. 22), os serviços federais têm grande peso no cotidiano de cidadãos e empresas, sendo numericamente significativos.

A maioria dos países tem um portal nacional que unifica os canais digitais e serviços dos órgãos federais. No Brasil, o portal fica em gov.br. O portal disponibiliza serviços em três estágios de digitalização: totalmente digital (100\% das etapas são processadas pelo próprio cidadão em autoatendimento), parcialmente digital (pelo menos uma etapa do processo ocorre por meio digital) e não digital (prestados por presença física ou só com informações disponíveis por meio digital). Existe um Painel de Monitoramento de Serviços Federais para apresentar a oferta de digitalização em tempo real (GOVERNO DO BRASIL, s/d).

Em fevereiro de 2021, o Painel de Monitoramento indicava haver 4.217 serviços disponíveis em 193 órgãos, sendo que 66,5\% dos serviços eram totalmente digitais, $15,2 \%$ parcialmente digitais e $18,3 \%$ não eram digitais. O tempo médio estimado entre a solicitação do serviço e a entrega era de 76 dias. Quanto à avaliação das informações disponíveis sobre os serviços, havia 69,9\% de avaliações positivas (1.686.853 respondentes) e 30,1\% de avaliações negativas (726.758 respondentes). A Figura 6 reproduz o Painel de Monitoramento em fevereiro de 2021.

Outra métrica para avaliar o estágio de digitalização do governo federal brasileiro é o Índice de Serviços Online, que compõe o Índice de Desenvolvimento de Governo Eletrônico da ONU. Colaboradores, pesquisadores e voluntários ligados à ONU avaliam escopo e qualidade de 148 aspectos de portais nacionais de serviços. O grupo procura reproduzir o papel de um cidadão comum acessando o site em busca de serviços. “O ponto-chave é que o usuário médio precisa encontrar

\footnotetext{
${ }^{74}$ Original em inglês: Changing mindsets, including beliefs and attitudes, is one of the most difficult challenges in implementing a digital government strategy.
} 
informações e recursos de forma rápida e intuitiva para que um site seja 'utilizável' com conteúdo facilmente descoberto pelos beneficiários a que se destina"75 (UNITED NATIONS, 2020, p.237).

Em 2020, o Brasil pontuou 0,8706 no Índice de Serviços Online da ONU, sendo o país líder na América do Sul. A liderança mundial era da Coréia do Sul, que pontuou 1,000. A média mundial era 0,5620.

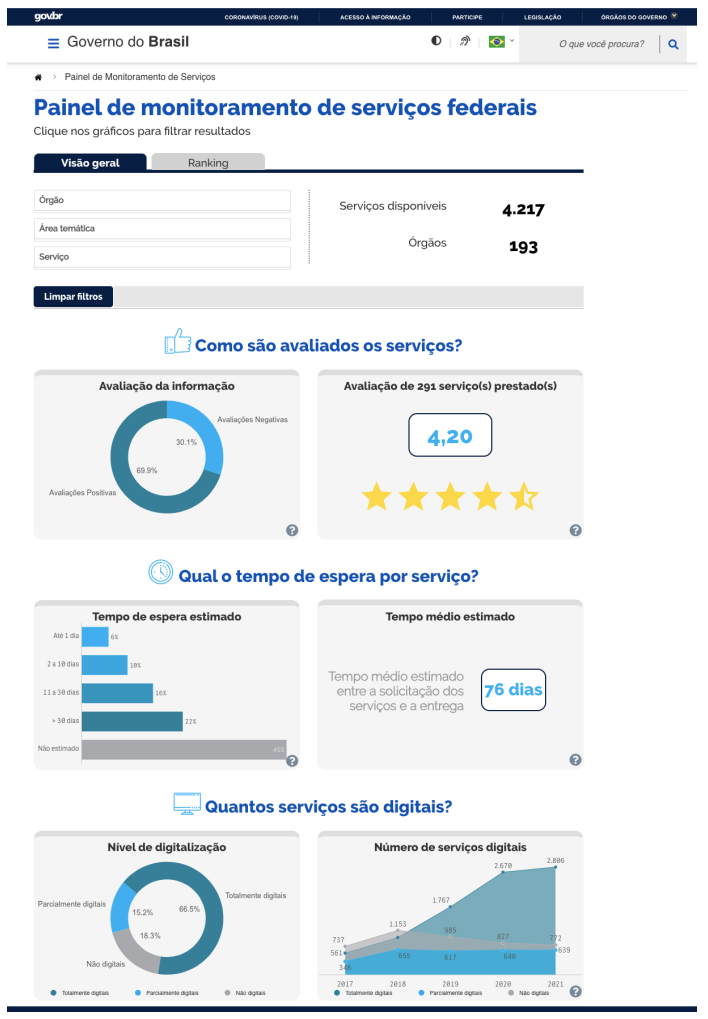

Figura 6: Painel de Monitoramento de Serviços Federais no mês de fevereiro de 2021. Fonte: Portal Gov.br.

\subsubsection{1.}

\section{Digitalização de atendimentos no INSS}

\footnotetext{
${ }^{75}$ Original em inglês: The key point is that the average user needs to find information and features quickly and intuitively for a site to be "usable" with content readily discoverable by the intended beneficiaries.
} 
O Instituto Nacional do Seguro Social (INSS) é uma autarquia ${ }^{76}$ federal que administra o Regime Geral de Previdência Social ${ }^{77}$. Em 2017, o INSS geria 50 milhões de segurados e 33 milhões de beneficiários. Benefícios são definidos como:

prestações pecuniárias pagas pela Previdência Social aos segurados ou aos seus dependentes de forma a atender a cobertura dos eventos de doença, invalidez, morte e idade avançada; maternidade; salário-família e auxílio-reclusão para os dependentes dos segurados de baixa renda; e pensão por morte do segurado, homem ou mulher, ao cônjuge ou companheiro e filhos. (ANUÁRIO, 2019, p.7)

Os principais benefícios pagos pelo INSS são aposentadorias, pensões e auxílios, sendo o Auxílio-doença ${ }^{78}$ o de maior procura. Ramos et al $(2019$, p. 6) aponta que um dos papéis mais importantes do INSS é reduzir a pobreza no Brasil, exercendo um papel fundamental na vida das pessoas, na economia domiciliar e no desenvolvimento dos municípios. O INSS atende a população por meios digital (app e site Meu INSS), telefônico (número 135) e físico (cerca de 1.600 agências).

Em 2018, foram realizados cerca de 46 milhões de atendimentos (ANUÁRIO, 2019, p. 952).

Os problemas de atendimento são recorrentes: serviços lentos e pouco confiáveis, com longos atrasos e baixa previsibilidade; serviços não flexíveis e nem adaptados aos cidadãos; interfaces mal projetadas e não centradas no usuário, com falta de clareza nas informações (RAMOS ET AL, 2019).

Em 2019, o instituto passou por um processo de transformação digital para disponibilizar totalmente online os serviços que não exigem avaliação por perícia médica (INSS, 2019). Em fevereiro de 2021, o Painel de Monitoramento de Serviços Federais indicava haver 91 serviços do INSS disponíveis no Portal Gov.br, sendo $91,2 \%$ totalmente digitais, $7,7 \%$ parcialmente digitais e $1,1 \%$ não digital. Entre os serviços parcialmente digitais, constam aqueles que requerem perícia,

\footnotetext{
${ }^{76}$ Definição de autarquia, segundo o Dicionário Houaiss online: "Entidade de direito público, com autonomia econômica, técnica e administrativa, embora fiscalizada e tutelada pelo Estado, o qual eventualmente lhe fornece recursos, e constitui órgão auxiliar de seus serviços".

${ }^{77}$ Previdência Social é uma política de seguro público que oferece proteção em momentos de perda de renda. Para se beneficiar do seguro é preciso fazer contribuições mensais.

${ }^{78}$ Renda mensal temporária paga aos segurados que precisam parar de trabalhar por motivo de doença.
} 
como o Auxílio-doença: algumas etapas do atendimento podem ser realizadas por meio digital, mas a perícia deve ser presencial. ${ }^{79}$

Vale observar que cerca de $70 \%$ da demanda do INSS dependem de avaliação de perícia médica. Em 2018, das 6,8 milhões de perícias médicas realizadas, 5,6 milhões foram relativas a Auxílio-doença (ANUÁRIO, 2019, p. 642-643).

Mesmo com limitações, é certo que a digitalização facilitou o acesso dos cidadãos ao INSS e aumentou a demanda por serviços, já que mesmo os serviços parcialmente digitais podem ser requeridos online. Entretanto, como foi comentado na seção 5.2. ("Reengenharia de serviços anterior à digitalização"), a transformação digital brasileira ainda não fez a necessária reengenharia de simplificação de processos operacionais para atender a demanda ampliada na internet. Isso não apenas intensificou antigos problemas de atendimento como criou novos problemas, relacionados às faltas de letramento digital, letramento governamental e letramento em leitura digital.

\begin{abstract}
Com a maior facilidade para se cadastrar e registrar pedidos, a demanda por serviços previdenciários aumentou significativamente e, com um sistema operacional ainda sem modernizações relevantes, foi registrado um aumento da fila de espera pela concessão de um benefício, mesmo com atendimentos mais rápidos (...) A digitalização do atendimento do INSS vem avançando sem um plano para auxiliar os cidadãos a utilizarem os serviços exclusivos através dos canais digitais. Desta forma, muitos usuários não conseguem acessar serviços que antes acessavam pela agência gerando um problema para as pessoas excluídas digitalmente. (RAMOS ET AL, 2019)
\end{abstract}

\title{
Melchiori (NÚCLEO DE INFORMAÇÃO E COORDENAÇÃO DO
} PONTO BR, 2020b) alerta que a digitalização da Previdência Social não tem envolvido adequadamente "os indivíduos mais vulneráveis no desenho dos sistemas, de forma que os problemas e as situações reais da vida das pessoas acabam não sendo antecipados e incorporados no design dos serviços”. A pesquisadora observa ainda que, em 2018, 68\% dos brasileiros com 60 anos ou mais nunca havia acessado a internet, justamente a faixa etária que mais depende da seguridade social.

\footnotetext{
${ }^{79}$ Durante a pandemia da Covid-19, as exigências de perícia presencial foram flexibilizadas, como no caso de prova de vida e atestados médicos para Auxílio-doença, que puderam ser encaminhados digitalmente (INSS, 2020).
} 
Quanto à avaliação das informações disponíveis sobre os serviços digitalizados do INSS no Gov.br, em fevereiro de 2021 havia 55,7\% de avaliações negativas e 44,3\% de avaliações positivas no Painel de Monitoramento de Serviços. A Figura 7 reproduz a imagem desses dados no Painel.

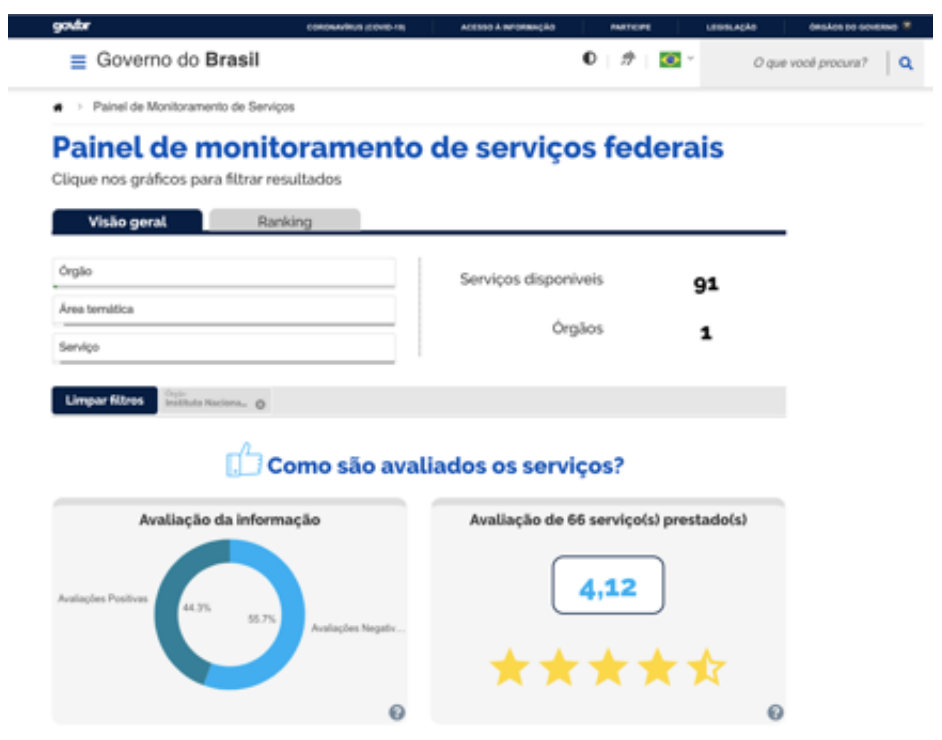

Figura 7: Avaliação dos serviços do INSS no Painel de Monitoramento de Serviços Federais. Fonte: Portal Gov.br.

Outra fonte que permite avaliar a qualidade das informações sobre serviços da Previdência Social no Brasil fica nas lojas de download do aplicativo MEU INSS, na seção onde os usuários classificam os apps e fazem comentários. Os comentários ali disponíveis não possibilitam qualquer tipo de filtro de busca.

Uma consulta aos comentários que constavam da Play Store Google, em dezembro de 2020, mostrava ser grande o volume de reclamações decorrentes da falta de clareza de informações no app MEU INSS. Havia pelo menos dois comentários com menção direta ao estilo do texto. O usuário Claudio Albuquerque dizia que "Linguagem do povo é linguagem simples e sem muita burocracia" e a usuária Jacineide Rodrigues registrava que “o app é bom, mas precisa melhorar alguns pontos. O primeiro é a escrita, não deveria ser tão técnica”. As reproduções de tela com esses comentários constam do Anexo 3. 


\subsection{3.}

\section{Orientações sobre informação fácil de compreender}

A compreensibilidade das informações oferecidas aos cidadãos em governo eletrônico vem sendo destacada desde os primeiros momentos da implantação do e-gov no Brasil.

No ano 2000, o Livro Verde, com orientações para o então recém-constituído Comitê Executivo de Governo Eletrônico (CEGE), criticava o uso de jargão na prestação de serviços públicos pela internet (TAKAHASHI, 2000, p. 78). Uma das resoluções do CEGE determinava que as páginas dos websites deveriam "ser de fácil legibilidade; apresentar os conteúdos com clareza e simplicidade; usar linguagem simples e direta” (BRASIL, 2002), sem indicar diretrizes de escrita.

Em 2005, o Departamento de Governo Eletrônico lançava o guia $e M A G$ Modelo de Acessibilidade em Governo Eletrônico. Dois anos depois, essas diretrizes viraram obrigatórias em todos os ambientes do governo brasileiro na internet. O guia seguia as orientações do Web Content Accessibility Guidelines $(W C A G)$, documento feito pela organização internacional $\mathrm{W} 3 \mathrm{C}$, que regula os padrões mundiais para a web. A versão mais recente é de 2014. As recomendações de acessibilidade do $e M A G$ destinam-se prioritariamente a pessoas com diversos tipos de deficiência.

As recomendações de acessibilidade do eMAG mencionam indivíduos com deficiência visual, auditiva, disléxicos, etc. Entretanto, há uma indicação clara de que o conceito de acessibilidade deve ser pensado de forma mais ampla:

Por isso, um sítio desenvolvido considerando a acessibilidade deve englobar diferentes níveis de escolaridade, faixa etária e pouca experiência na utilização do computador, bem como ser compatível com as diversas tecnologias utilizadas para acessar uma página da Web. (PROGRAMA DE GOVERNO ELETRÔNICO BRASILEIRO, 2014)

Em 2010, o estudo Avaliação de 200 sítios e e-serviços do Governo Eletrônico Brasileiro indicava como problema mais recorrente os links que não apresentavam descrições curtas e objetivas. O erro foi encontrado em $95 \%$ dos sites pesquisados. No mesmo ano, o Departamento de Governo Eletrônico publicou a Cartilha de Usabilidade com recomendações de boas práticas na disposição das informações em interfaces digitais, priorizando as necessidades do usuário. A 
diretriz "Redação" dizia que "o sítio deve 'falar' a língua das pessoas, com palavras, frases e conceitos familiares e o texto deve ser objetivo". E especificava: "A linguagem utilizada na divulgação das informações e orientações para realização de serviços deve ser clara e objetiva" (BRASIL, 2010, p. 26)

Em 2016, a Política de Governança Digital determinou nove princípios de conduta nas plataformas digitais federais, entre eles "foco nas necessidades da sociedade" e "simplicidade" (BRASIL, 2016a). A Estratégia de Governança Digital, documento que estabeleceu objetivos, metas e indicadores daquela política, determinou que um princípio deve ser sempre apresentado "em linguagem simples e expressar com máxima clareza os valores fundamentais de uma organização" (BRASIL, 2016 b).

Em 2020, uma portaria do Ministério das Comunicações estipulou o Manual de Diretrizes Gov.br com uma série de procedimentos para a unificação dos sites dos órgãos ao modelo do portal único de serviços. O Manual cobria aspectos relativos ao estilo textual, destacando-se os seguintes:

Linguagem do cidadão: A linguagem utilizada deve ter como referência um vocabulário simples e próximo à realidade dos brasileiros. É importante evitar termos técnicos e palavras rebuscadas. Contudo, deve-se seguir a norma culta da língua portuguesa sem que isso atribua um tom erudito à mensagem. Como destaca o professor Carlos Alberto Faraco, não se deve confundir oralidade com informalidade.

Frases e textos curtos: Orações e períodos longos tornam a leitura cansativa e mais complexa. Além disso, podem fazer com que o leitor esqueça do tema inicial abordado ou quem é o sujeito da ação. Evite períodos longos, com mais de duas linhas e muitas vírgulas. Apresente uma ideia em cada oração. As melhores práticas de legibilidade recomendam frases com até 30 palavras para assegurar a fluidez da leitura. Essa tática também minimiza a quantidade de redutores de velocidade, como vírgulas, pronomes relativos e erros de concordância.

Construir frases, títulos e linha fina sempre na ordem direta: A voz ativa dá clareza à lógica da ação relatada. A estrutura básica sujeito + verbo + predicado facilita a compreensão do texto.

Parágrafos curtos: Estudo de Eye Track III, do Instituto Poyter, mostrou que parágrafos curtos, com menos de 50 palavras, atraem o dobro da atenção dos usuários. Na arquitetura do portal Institucional Padrão, é possível manter esse padrão em parágrafos com até três linhas. (MINISTÉRIO DAS COMUNICAÇÕES, 2020) 


\section{5.}

\section{Linguagem Simples em portais nacionais de serviços}

A maioria dos países-membros da ONU tem um portal nacional de serviços voltado a cidadãos e empresas. O portal nacional é, inclusive, um dos itens avaliados pelo Índice de Desenvolvimento em Governo Eletrônico da ONU. A esta pesquisa, interessou verificar quais dos países estrangeiros citados na cronologia do movimento Plain Language (seção 4.2.1.) haviam incorporado e tornado públicas as recomendações de Linguagem Simples nos seus portais de serviços.

A cronologia citou onze países, a saber: África do Sul, Austrália, Canadá, Estados Unidos, Nova Zelândia e Reino Unido (língua inglesa); Argentina, Chile e Colômbia (língua espanhola); Portugal e Suécia. À lista de onze países, incluiu-se o Brasil, chegando-se, então, a um total de doze países.

A verificação consistiu em consultar os portais nacionais em busca de guias de edição de serviços - ou materiais similares - que cobrissem estilo de escrita e mencionassem Linguagem Simples. Tais materiais costumam destinar-se a servidores públicos que redigem textos para os portais, mas ficam disponíveis para consulta. A verificação foi feita em fevereiro de 2021.

Não foi localizado um portal nacional de serviços da Suécia. Só foram encontrados os sites sweden.se, com fatos e informações culturais sobre o país, e government.se, com informações sobre o funcionamento da máquina pública sueca (ambos em inglês). Nenhum deles trazia um agregado de serviços públicos, nem indicava guias relacionados à edição de conteúdos. Assim sendo, a Suécia foi desconsiderada.

Os resultados da verificação nos onze países serão relatados a seguir, em ordem alfabética.

África do Sul: Não foi localizada no portal gov.za uma seção com guias ou orientações para edição de serviços. Tampouco foram encontrados links que remetessem a outros sites governamentais sul-africanos que fossem responsáveis por conteúdos digitais para o portal. Não se localizou qualquer menção textual a uso de linguagem fácil de entender por meio de buscas dentro do portal de serviços.

Argentina: No argentina.gob.ar, na seção Acerca de este sitio (Sobre este site), havia um texto dizendo que o portal seguia "padrões que favorecem uma 
construção colaborativa de conteúdo", indicando um link que levava à área Contenidos Digitales (Conteúdos Digitais), dentro do próprio portal. O título desta área é "Ferramentas para a construção colaborativa de conteúdos da Plataforma Digital do Setor Público Nacional" "80. Lá, há uma subseção com recomendações de Linguagem Simples (ARGENTINA.GOB.AR, s/d). É interessante notar a preferência do governo argentino pelo termo Lenguaje Simple em vez de Lenguaje Claro, que é a tradução mais usada em língua espanhola.

Austrália: Não foi localizada no portal info.australia.gov.au uma seção com guias ou orientações para edição de serviços, nem foram encontrados links que remetessem a outros sites governamentais indicando tal responsabilidade. Também não se localizou qualquer menção textual a uso de linguagem fácil de entender fazendo buscas dentro do portal de serviços. Ocorre que existem, sim, diretrizes de uso de Linguagem Simples: elas não estão disponíveis no portal nacional de serviços, mas no site da Digital Transformation Agency (Agência de Transformação Digital) conforme será apresentado no próximo capítulo.

Brasil: No menu principal do portal gov.br, existia o item Guia de Edição de Serviços do Gov.br. No guia, o módulo "Como melhorar o texto de um serviço (linguagem simples)" trazia as diretrizes que já foram comentadas seção 4.5. (“Adoção de Linguagem Simples pelo setor público brasileiro").

Canadá: No portal canada.ca, o item de menu About government (Sobre o governo) levava à seção Digital Government (Governo Digital). Lá, constava o item Standards, policies and guidance (Normas, políticas e orientações), de onde era possível acessar o link Canada.ca design system, também abrigado dentro do portal de nacional de serviços. Esse link trazia uma série de orientações, inclusive as diretrizes de Linguagem Simples que serão apresentadas no próximo capítulo.

Chile: Não foi localizada no portal chileatiende.gob.cl uma seção com guias ou orientações para edição de serviços, nem foram encontrados links que remetessem a outros sites governamentais indicando tal responsabilidade. Foi localizada no portal apenas a seguinte frase, sem indicar links ou disponibilizar arquivos: "Encontre informações em linguagem simples e clara". Entretanto, existem diretrizes de Linguagem Simples no site do órgão público chileno chamado Laboratorio de Gobierno, conforme será apresentado no próximo capítulo.

${ }^{80}$ Original em espanhol: Herramientas para la construcción colaborativa de contenidos de la Plataforma Digital del Sector Público Nacional. 
Colômbia: Não foi localizada no portal gov.co, uma seção com guias ou orientações para edição de serviços, nem foram encontrados links que remetessem a outros sites governamentais indicando tal responsabilidade. Vale observar que o portal nacional de serviços havia sido oficialmente lançado dois meses antes da verificação. Como já foi informado no capítulo 4, a Colômbia é uma grande referência de uso governamental de Linguagem Simples, fazendo parte das políticas nacionais de atendimento ao cidadão. As diretrizes estão disponíveis no site do órgão público colombiano DNP, conforme será apresentado no próximo capítulo.

Estados Unidos: No portal usa.gov, o item de menu About USA.com (Sobre o USA.gov) listava a seção USAGov Bilingual Style Guide (Guia de Estilo Bilíngue USA.Gov). Lá, bastava usar o subitem Writing for the Web (Escrevendo para a Web) e acessar um conjunto reduzido de diretrizes de Linguagem Simples. O portal remetia aos links do site plainlanguage.gov (que será apresentado no próximo capítulo) e à agência federal de transformação digital 18F, que tem uma seção dedicada ao tema (18F CONTENT GUIDE, s/d).

Nova Zelândia: No portal govt.nz, o item de menu About this website (Sobre este website) listava a seção Govt.nz content design (Design de conteúdo para o govt.nz), que, por sua vez, indicava o link externo Content Design Guidance (Orientação para Design de Conteúdo), que levava para o site www.digital.govt.nz. Lá era destacada a relevância de redigir os textos em Linguagem Simples, mas as diretrizes recomendadas eram as de um site externo, não relacionado ao governo neozelandês. Essas diretrizes de Linguagem Simples serão apresentadas no próximo capítulo.

Portugal: No portal eportugal.gov.pt, constava que o objetivo do portal é "facilitar as interações entre cidadãos e empresas e o Estado, tornando-as mais claras e simples". Informava-se que o portal é responsabilidade da Agência para a Modernização Administrativa (AMA), com link para esse órgão. No site da agência, dizia-se que "com o ePortugal, as fichas de serviços mais relevantes para cidadãos e empresas foram revistas para tornar a sua linguagem mais simples e clara" (AMA, s/d). Entretanto, não havia uma seção naquele site com orientações de Linguagem Simples, nem indicação de links externos. Essas orientações estão, sim, disponíveis no site de um outro órgão público português, o LabX, conforme será apresentado no próximo capítulo. 
Reino Unido: Na página inicial do portal gov.uk, havia um bloco chamado Departments and policy (Departamentos e políticas), onde constava o link Guidance and regulations (Orientação e regulamentos). Este link remetia a uma página onde era possível buscar serviços por tópico. Foi feita uma busca pelo tópico Government (Governo) e o sub-tópico Government technology and digital services (Tecnologia governamental e serviços digitais). Entre os resultados, estava o link Content design: planning, writing and managing contente (Design de conteúdo: planejamento, redação e gerenciamento de conteúdo). Ali ficava a seção Writing for GOV.UK (Escrevendo para o GOV.UK), aninhada dentro do próprio portal nacional de serviços, onde constavam as diretrizes de Linguagem Simples que serão analisadas no próximo capítulo.

\section{6}

\section{Síntese do capítulo 5}

Entre os conceitos que orientam a estruturação de e-govs em todo o mundo, este capítulo enfatizou a perspectiva da defendida pela Organização das Nações Unidas. A ONU observa que governos eletrônicos existem para contribuir com os objetivos da Agenda 2030 para o Desenvolvimento Sustentável, ou seja, "ninguém deve ser deixado para trás". Neste sentido, a digitalização precisa apoiar as mudanças necessárias dentro e fora de governos, ter abordagem holística e inclusiva, pois o objetivo final é gerar valor público (UNITED NATIONS, 2018). O capítulo mostrou como são grandes os desafios para alcançar tais metas.

$\mathrm{O}$ atendimento em governo eletrônico é mais rápido, mais barato, promove a transparência e inibe a corrupção. Entretanto, ergue barreiras que prejudicam ou impedem o acesso aos serviços, causando exclusão digital e agravando as desigualdades sociais. A linguagem não deve ser mais um fator de segregação (ROSETH, REYES E SANTISO, 2018b).

Viu-se que, muitas vezes, trâmites burocráticos antigos são levados para plataformas digitais sem passar pela esperada reengenharia de simplificação. Os problemas de compreensão que já existiam off-line são amplificados. A expectativa seria que as informações de governo eletrônico fossem comunicadas em um estilo textual fácil de compreender, pois são poucas as chances de esclarecer dúvidas. 
Foi destacada a trajetória de progresso do Brasil no Índice de Desenvolvimento em Governo Eletrônico da ONU: o país pretende transformar todos os serviços públicos federais digitalizáveis até 2022 (BRASIL, 2020). Mas enfatizou-se o descompasso entre crescente a oferta de e-serviços e a adesão dos brasileiros ao autoatendimento digital, que vem encolhendo. Se há 95\% dos órgãos públicos com website na internet, a grande maioria da população que acessa esses sites apenas o faz para verificar informações: só $10 \%$ realizam o serviço de forma totalmente digital (NÚCLEO DE INFORMAÇÃO E COORDENAÇÃO DO PONTO BR, 2020b). Achar o contato com o governo pela Internet complicado é um dos motivos mais desmotivadores.

Problemas decorrentes da digitalização de governos são complexos e multifacetados, requerendo intervenções em variadas frentes. Porém, como a falta de clareza é uma das reclamações constantes, as simplificações no estilo textual contribuirão para aumentar a compreensibilidade das informações e, consequentemente, podem resultar em maior adesão ao autoatendimento online.

Portais nacionais de serviço de vários países recomendam o uso de Linguagem Simples. A verificação realizada constatou que as recomendações podem estar inseridas dentro dos próprios portais de serviços, em sites de órgãos públicos ligados à transformação digital dos governos ou em links externos.

Diretrizes governamentais de Linguagem Simples são o foco do próximo capítulo, que detalhará como foi realizado o levantamento documental que compilou e categorizou as diretrizes de Linguagem Simples em onze governos. 


\section{Levantamento documental}

A fundamentação sobre compreensibilidade textual (capítulo 2), burocratês (capítulo 3), Linguagem Simples (capítulo 4) e governo eletrônico (capítulo 5) forneceu os parâmetros para conduzir o levantamento documental e o estudo experimental da presente pesquisa. Este capítulo relata o levantamento documental das diretrizes de Linguagem Simples recomendadas por governos para uso em serviços digitais. O levantamento gerou parâmetros para a reescrita do texto que seria usado no estudo experimental que avaliou a compreensibilidade de informações sobre o Auxílio-doença no site do INSS, conforme será descrito no próximo capítulo.

O estudo experimental requeria duas versões do texto sobre o Auxíliodoença: a texto original do site do INSS e uma versão reescrita em Linguagem Simples. Como foi relatado no capítulo 4 , ainda não existe um padrão normativo da técnica de Linguagem Simples ${ }^{81}$. Assim sendo, havia dois caminhos para compor a reescrita do experimento: (1) escolher aleatoriamente uma organização que adote a Linguagem Simples e usar as diretrizes por ela recomendadas ou (2) coletar e sistematizar diretrizes de diversas organizações, identificar as diretrizes mais recorrentes e aplicá-las na reescrita do texto. Optou-se pela sistematização de diversas organizações - no caso, nove governos internacionais e três governos nacionais. Além de informar a reescrita do texto do experimento, seria uma oportunidade para mapear como o setor público vem usando a Linguagem Simples em governo eletrônico.

O presente capítulo registra o passo-a-passo do levantamento documental, detalhando os critérios de compilação e categorização das diretrizes. Serão

\footnotetext{
${ }^{81}$ Há um processo em curso junto à International Standards Organization-ISO para validar um normativo internacional de Plain Language. Os detalhes constam da seção 4.3. ("Técnica de comunicação: de descentralizada a padronizada").
} 
apresentados os quadros temáticos compostos a partir da categorização e as diretrizes mais recorrentes. Por fim, serão discutidos os resultados do levantamento.

\section{1 .}

\section{Objetivos e critérios}

Dois objetivos nortearam o levantamento das diretrizes governamentais:

- Estado da arte - Localizar os documentos oficiais que estabelecem as diretrizes; conhecer o contexto para o qual foram elaborados; verificar seus produtores e os referenciais teóricos utilizados; compilar as diretrizes que fossem comuns a dois ou mais governos;

- Orientar a reescrita do texto usado no estudo experimental - A identificação das diretrizes de Linguagem Simples mais recorrentes poderia informar a reescrita do texto a ser usado no estudo experimental.

Entre os governos internacionais que atualmente recomendam o uso de Linguagem Simples, foram escolhidos cinco países de língua inglesa (Austrália, Canadá, Estados Unidos, Reino Unido e Nova Zelândia), dois países de língua espanhola (Colômbia e Chile) e um de língua portuguesa (Portugal). Do Brasil, foram incluídos entes governamentais dos âmbitos municipal (Prefeitura de São Paulo), estadual (Governo do Estado do Ceará) e federal (Secretaria de Governo Digital do Ministério da Economia, órgão responsável pelo portal de serviços Gov.br).

Nos países de língua inglesa, as recomendações de Linguagem Simples fazem parte dos padrões de produção de conteúdo para serviços públicos digitais. Esses padrões já foram apontados na seção 5.5. ("Linguagem Simples em portais nacionais de serviços”), pois a maioria deles está acessível pelos portais.

Chile e Portugal foram escolhidos porque a Linguagem Simples se insere nos esforços de inovação e digitalização de serviços públicos federais. A escolha da Colômbia deveu-se tanto ao peso da Estrategia de Lenguaje Claro na administração federal - conforme já detalhado na seção 4.2.1 ("Cronologia do movimento internacional: anos 1940-2010”) - como à influência que teve nos programas de Linguagem Simples no português europeu e brasileiro. Quanto aos entes governamentais do Brasil, eram os únicos que oficialmente recomendavam a 
Linguagem Simples na digitalização de serviços quando o levantamento foi feito, entre os meses de março e novembro de 2020.

O levantamento não contemplou as diretrizes usadas pelo governo da Argentina mencionadas no capítulo 5 porque elas só foram localizadas quando o levantamento documental estava concluído ${ }^{82}$.

\section{2.}

\section{Documentos com diretrizes governamentais de Linguagem Simples}

O escopo das diretrizes variava de acordo com cada governo. Os documentos mais extensos cobriam um número maior de recomendações e ofereciam argumentos adicionais às diretrizes em si. Já os mais compactos se limitavam alistar as diretrizes em frases sucintas. Dada a extensão dos documentos, o Anexo 1 reproduz somente a página inicial dos sites onde constavam as diretrizes.

A seguir, são apresentados o contexto em que as diretrizes foram localizadas, os responsáveis pela produção dos materiais e os referenciais teóricos mencionados. Também é indicado o número de páginas de cada documento, considerando o formato PDF (portable document file). As informações foram agrupadas conforme o idioma dos documentos.

\subsection{1.}

\section{Documentos em língua inglesa}

Austrália - As diretrizes foram coletadas em março de 2020 no site oficial guides.service.gov.au. Elas faziam parte do Guia de Conteúdo (Content Guide) do Padrão de Serviço Digital do governo australiano, na seção sobre conteúdo textual. O documento fazia menção a evidências - tais como o cérebro de um adulto conseguir entender conteúdos mesmo se descartar 30\% do texto; e a maioria das

\footnotetext{
${ }^{82}$ As diretrizes do governo argentino são semelhantes às dos governos que serão detalhados no levantamento documental. O órgão responsável pelo material parece ser a Secretaria de Inovação Pública, órgão ao qual à página internet das diretrizes está vinculada. As diretrizes fazem parte do guia de produção de conteúdos digitais. Entre as diretrizes indicadas, constam: usar parágrafos curtos; organizar a informação conforme pirâmide invertida; usar recursos visuais; preferir voz ativa; evitar negativas, jargão e tecnicismos. (ARGENTINA.GOB.AR, s/d)
} 
pessoas ler reconhecendo a forma das palavras, sem ler cada letra individualmente. Entretanto, as fontes das evidências não eram mencionadas e nem havia links para artigos e pesquisas de referência. Responsável pelo material: Agência de Transformação Digital (DTA-Digital Transformation Agency). Tamanho do documento: 7 páginas. (AUSTRALIAN GOVERNMENT, s/d).

Canadá - As diretrizes foram coletadas em março de 2020 na seção Design System do portal federal Canada.ca. Elas faziam parte do Content Style Guide (Guia de Estilo de Conteúdo) e estavam disponíveis em inglês e francês, sendo iguais nos dois idiomas. Só havia diferença na recomendação do número máximo de palavras por frase: 20 palavras em inglês, 24 em francês. Não havia menção a referenciais teóricos que embasassem as orientações. Responsável pelo material: Não havia menção explícita à área responsável, mas havia um link para a Secretaria do Conselho do Tesouro Canadense. Tamanho do documento: 9 páginas. (CANADA.CA, s/d)

Estados Unidos - As diretrizes foram coletadas em março de 2020 no site plainlanguage.gov, dedicado exclusivamente ao tema. O item de menu Plain Language Guidelines (Diretrizes de Linguagem Simples) abrigava oito subitens, cada qual com inúmeras orientações. Ao fim de todo subitem, havia uma seção chamada Sources (Fontes) indicando uma seleção de guias de Linguagem Simples com foco em linguagem jurídica, manuais genéricos de escrita com clareza, manuais de redação para web, manuais de redação oficial, dicionários e outros livros no campo do Direito. Essas fontes de referências quase sempre repetiam-se nos capítulos, com raras exceções. Entretanto, o subitem Follow Web Standards (Siga Padrões Web) indicava estudos de usabilidade, a maioria produzida pelo Nielsen Norman Group. Havia menção a um livro sobre estudos de eyetracking na usabilidade web, de Jakob Nielsen e Kara Pernice. Responsável pelo material: Rede de servidores públicos federais chamada Plain Language Action and Information Network. Tamanho do documento: 92 páginas. (PLAINLANGUAGE.GOV, s/d)

Nova Zelândia - As diretrizes foram coletadas em junho de 2020 no site oficial digital.govt.nz, que é ligado ao Ministério de Economia e Comunicações Digitais. As orientações de Linguagem Simples foram acessadas a partir no subtitem de menu Content design guidance (Orientação para design de conteúdo) dentro do site oficial neozelandês. Entretanto, os links de diretrizes de Linguagem Simples direcionavam para um site externo, do projeto colaborativo global 
Readability Guidelines, liderado pela empresa britânica de consultoria Content Design London. O projeto define-se como "baseado em evidências de usabilidade" 83 (CONTENT DESIGN LONDON, s/d). De fato, havia 46 links para estudos e pesquisas embasando as diretrizes apresentadas. Responsável pelo material: O órgão de contato que constava da página Plain Language no site da Nova Zelândia era o Government Information Services/ Department of Internal Affairs. Tamanho do documento: 5 páginas, incluindo os links. (DIGITAL.GOVT.NZ, s/d)

Reino Unido - As diretrizes foram coletadas em março de 2020 no portal nacional de serviços GOV.UK. As diretrizes de Linguagem Simples estavam listadas na subseção Writing for GOV.UK (Escrevendo para o GOV.UK), dentro da seção Content design: planning, writing and managing content (Design de conteúdo: planejamento, redação e gerenciamento de conteúdo). O documento trazia a seguinte afirmativa: "Nossa orientação de escrita para o GOV.UK baseiase em pesquisas sobre como as pessoas lêem online e como elas usam o GOV.UK. O embasamento de cada regra é explicado" (GOV.UK, s/d). ${ }^{84}$ Havia referências a pesquisas da consultoria americana Nielsen Norman Group, a estudos com pessoas de alta escolaridade e a uma pesquisa sobre o uso de linguagem jurídica, entre outros, todos com link. A subseção Writing for GOV.UK (Escrevendo para o GOV.UK) fazia muitas menções à Linguagem Simples, mas havia um subitem especificamente intitulado Plain English. Para efeito do levantamento, foram consideradas as orientações que constavam daquele subitem, todas focadas em escolha de palavras. Responsável pelo material: setor Government Digital Service, responsável por serviços digitais do governo britânico. Tamanho do documento: Menos de meia página. (GOV.UK, s/d).

\section{2 .2}

\section{Documentos em língua espanhola}

Chile - As diretrizes foram coletadas em abril e 2020 no site do Laboratorio de Gobierno, órgão da Secretaria Geral da Presidência da República responsável

\footnotetext{
${ }^{83}$ No original em inglês: "based on usability evidence".

${ }^{84}$ No original em inglês: "Our guidance on writing for GOV.UK is based on research into how people read online and how people use GOV.UK. It explains what each rule is based on."
} 
por inovações na prestação de serviços públicos. O laboratório desenvolveu a série de guias Permitido Innovar, com propostas metodológicas para processos de inovação. Um dos guias chama-se ¿Como podemos generar una comunicación simple, clara y efectiva entre el Estado y la ciudadania? (Como podemos gerar uma comunicação simples, clara e efetiva entre o estado e a cidadania?). No capítulo ¿Cómo co-creamos protótipos comunicacionales a nível de contenidos? (Como cocriamos protótipos comunicacionais em termos de conteúdo?), havia um check-list com diretrizes para revisar textos. Essas foram as diretrizes consideradas no levantamento. O guia não menciona referenciais teóricos ou pesquisas que embasem as orientações, apenas mencionando um manual de Linguagem Simples do governo do México ${ }^{85}$. Responsável pelo material: Laboratório de Gobierno, com a colaboração de membros da Red de Lenguaje Claro Chile. Tamanho do documento: Meia página. (LABORATORIO DE GOBIERNO, s/d)

Colômbia - As diretrizes foram coletadas em abril de 2020 no site do Departamento Nacional de Planeación (DNP), o órgão responsável pelo Programa Nacional de Serviço ao Cidadão (Programa Nacional del Servicio al Ciudadano), onde se insere a Estratégia de Linguagem Simples (Estrategia de Lenguaje Claro). Havia duas publicações com diretrizes: o Guia de Lenguaje Claro para Servidores Públicos de Colombia, editado em 2015, e o Guia 10 Pasos para Comunicarse en Lenguaje Claro. Esse último é mais compacto, mais recente e enfatiza o uso em plataformas digitais: por isso, foi escolhido para o levantamento. Não havia menção a referenciais teóricos que embasem as orientações de Linguagem Simples. Responsável pelo material: DNP. Tamanho do documento: 12 páginas, sendo várias ocupadas apenas por ilustrações. (DNPx, s/d)

\section{2 .3}

\section{Documentos em língua portuguesa}

Portugal - As diretrizes foram coletadas em setembro de 2020 por meio de correspondência eletrônica com a servidora Carla Outor, do LabX-Laboratório de Experimentação da Administração Pública do governo português (OUTOR, 2020).

\footnotetext{
${ }^{85}$ O programa de Linguagem Simples do México foi pioneiro na América Latina (2005), mas está inativo, conforme foi mencionado na seção 4.2. ("Cronologia do movimento internacional: anos 1940-2010”). Por isso, as diretrizes mexicanas não foram incluídas no levantamento.
} 
O LabX faz parte da Agência para a Modernização Administrativa-AMA e vem desenvolvendo metodologias de simplificação de serviços públicos. $\mathrm{O}$ uso de Linguagem Simples é abordado no Manual de Aplicação de Oficinas de Simplificação. Lá, consta um link que remete às 10 Guias Orientadoras de Linguagem arquivadas no serviço de armazenamento de dados em nuvem da AMA. É necessário usar a senha "guias" (sem as aspas) para acessar o arquivo na nuvem da AMA. Quanto ao embasamento das diretrizes, o manual indicava links de três referências colombianas: o Guia de Lenguaje Claro para Servidores Públicos de Colombia; uma apresentação da Red de Lenguaje Claro Colombia; e um vídeo pedagógico abrigado no site do DNP. Responsável pelo material: LabX. Tamanho do documento: 5 páginas. (AMA, s/d)

Brasil - As diretrizes foram coletadas em outubro de 2020 no portal de serviços Gov.br do governo federal, que é administrado pela Secretaria de Governo Digital do Ministério da Economia. O portal tinha uma seção chamada Guia de Edição de Serviços do Gov.br. Lá, encontrava-se a subseção Como melhorar o texto do seu serviço (linguagem simples), com os itens Planejando, Escrevendo, Revisando e Para aprender rindo. Todo o conteúdo desses itens aborda aspectos relacionados à escrita com clareza. Em uma outra subseção do portal Gov.br, chamada Publicações e Cursos, ficava o link para a Matriz resumida para revisar um texto com técnicas de Linguagem Simples. Para efeito deste levantamento, considerou-se a matriz como um instrumento sintetizador das diretrizes do Guia de Edição. Quanto a embasamento teórico, havia referências às diretrizes de Linguagem Simples do governo americano e ao artigo How little do users read?, de Jakob Nielsen, mas sem indicar os links. Responsável pelo material: Secretaria de Governo Digital. Tamanho do documento: 2 páginas. (GOV.BR, s/d)

Governo do Estado do Ceará - As diretrizes foram coletadas em maio de 2020 em troca de e-mail com a servidora Isabel Ferreira Lima, do Íris-Laboratório de Inovação e Dados do Governo do Estado do Ceará (LIMA, 2020). O Íris concebeu e vem desenvolvendo um programa estadual de Linguagem Simples, com foco em serviços públicos digitais. Na ocasião do levantamento, nem o laboratório nem o programa tinham um site próprio. O folheto digital 10 Passos para Escrever em Linguagem Simples estava armazenado no Google Drive do laboratório, podendo ser acessado pelo perfil do Íris na rede social Instagram. Não foram localizados referenciais teóricos que embasem as orientações de Linguagem 
Simples. Responsável pelo material: Íris Laboratório. Tamanho do documento: 1 página. (IRISLABGOV, s/d)

Prefeitura de São Paulo - As diretrizes foram coletadas em abril de 2020 no site oficial do Programa Municipal de Linguagem Simples. O programa foi concebido e é desenvolvido pelo (011) Lab-Laboratório de Inovação em Governo da Prefeitura de São Paulo, ligado à Secretaria Municipal de Inovação e Tecnologia. O manual 10 Dicas para Escrever um Documento em Linguagem Simples reúne as diretrizes que o programa recomenda. Não foi localizado embasamento teórico das diretrizes, mas o programa paulistano já divulgou ter buscado referências na Estrategia de Lenguaje Claro da Colômbia (ENCONTRO, 2019). Responsável pelo material: (011)lab. Tamanho do documento: 1 página. (PROGRAMA, s/d)

\section{3.}

\section{Categorização e agrupamento das diretrizes}

As diretrizes dos onze governos que compuseram o levantamento documental são fruto de recomendações divulgadas há várias décadas pelo movimento internacional Plain Language. O capítulo 4 mostrou que esse movimento começou nos Estados Unidos e no Reino Unido, nos anos 1940, quando servidores públicos começaram a propor alternativas ao burocratês. Com o passar do tempo, as recomendações concebidas originalmente em inglês foram sendo assimiladas por outras línguas.

Por mais que as características linguísticas do burocratês em português, espanhol e inglês sejam praticamente as mesmas - como já foi discutido no capítulo 3 -, é preciso considerar que cada idioma tem as suas particularidades estruturais. Logo, na busca de padrões comuns às diretrizes dos onze governos, buscou-se verificar o que era compartilhado e o que refletia características morfossintáticas pragmáticas e discursivas das línguas em que as diretrizes se expressam: inglês, espanhol e português (europeu e brasileiro). Além disso, também foram observadas possíveis diferenças de caráter sócio-interacional relacionadas às práticas comunicacionais de cada país. 
O trabalho de categorização começou com o exame individual dos documentos. Cada diretriz foi associada a palavras-chave indicativas da temática que abordava.

Optou-se por começar o processo de categorização sem um conjunto prédeterminado de palavras-chave, que foram sendo atribuídas em formato livre, conforme a avaliação da pesquisadora.

$\mathrm{Na}$ maioria das diretrizes, a associação a uma palavra-chave era óbvia. Exemplos: Para a diretriz chilena "Usam-se frases afirmativas" 86 , foi atribuída a palavra-chave Afirmativa. Para a diretriz paulistana "Evite escrever frases com mais de 20 palavras", foram atribuídas as palavras-chave Tamanho de frase. E para a diretriz australiana "Use várias frases curtas em vez de uma frase longa separada por pontuação" ${ }^{87}$, foram atribuídas as palavras-chave Quebra de frase grande em menores.

Mas houve casos em que a associação entre diretriz e palavra-chave era menos óbvia. Exemplos: Para a diretriz australiana "Use voz ativa. A voz ativa vai direto ao ponto" 88 , foram atribuídas as palavras-chave Voz ativa e Objetividade. Para a diretriz britânica "Seja aberto e específico" 89 foram atribuídas as palavraschave Transparência e Objetividade.

As atribuições em formato livre geraram mais de 100 palavras-chave. Ao fim do processo, foi feita uma revisão para unificar nomenclaturas, chegando-se a 83 palavras-chave.

O passo seguinte foi buscar um parâmetro para o agrupamento temático das diretrizes. Verificou-se a adequação de agrupar as palavras-chave conforme as cinco áreas de concentração indicadas pela Associação Internacional de Linguagem Simples (Plain Language Association International-PLAIN): Público-alvo e propósito, Estrutura, Design, Expressão verbal e Avaliação (PLAIN, s/d) ${ }^{90}$.

As áreas indicadas pela PLAIN mostraram-se adequadas para agrupar as palavras-chave que o levantamento havia gerado, sendo necessárias apenas adaptações pontuais. As áreas Público-alvo e propósito foram unificadas com o

\footnotetext{
${ }^{86}$ Original em espanhol: Se usan frases afirmativas.

${ }^{87}$ Original em inglês: Minimize punctuation. Use several short sentences instead of a long sentence broken up with punctuation.

${ }^{88}$ Original em inglês: Use active voice Active voice gets straight to the point.

${ }^{89}$ Original em inglês; Be open and specific.

${ }^{90}$ Original em inglês: Audience and purpose; Structure; Design; Expression; Evaluation.
} 
nome Princípios Norteadores. Estrutura passou a se chamar Estrutura da Informação. Design passou a se chamar Recursos Visuais. Expressão foi desmembrada em Escolha de Palavras, Construção de Frases e Construção de Parágrafos. Avaliação passou a se chamar Ações de Avaliação.

Assim sendo, as 83 palavras-chave do repositório foram agrupadas conforme as seguintes áreas de concentração: Princípios Norteadores, Estrutura da Informação, Recursos Visuais, Escolha de Palavras, Construção de Frases, Construção de Parágrafos e Ações de Avaliação. Nesse momento, constatou-se haver 27 palavras-chave que haviam sido indicadas por um só governo. Essas incidências únicas foram desconsideradas pois o objetivo do levantamento era identificar recomendações que fossem comuns aos onze governos. Por fim, chegouse então às seguintes 56 palavras-chave de diretrizes que são recomendadas por dois ou mais governos:

- Princípios Norteadores ${ }^{91}$ - Empatia, Proximidade/Tom dialógico, Cordialidade, Autoridade, Respeito, Objetividade, Transparência, Adequação aos padrões web, Redução de esforço cognitivo, Atenção às regras de acessibilidade e Atenção às necessidades informacionais do usuário.

- Estrutura da Informação - Planejamento prévio, Definição da organização do texto, Orientação para a tarefa, Ordem lógica/ Fluxo, Uso de pirâmide invertida, Uso de títulos/subtítulos e Segmentação conforme o público.

- Recursos Visuais - Imagens, Tabelas, Gráficos e infográficos, Diagramas, Marcadores para listar tópicos, Distribuição de espaços em branco, Divisão do texto em pequenos blocos e Coerência de tipografias/estilos.

- Escolha de Palavras - Compilação de termos simplificados, Preferir: Familiares, Concretas, Curtas, Gênero neutro e Pronomes na $1^{\mathrm{a}}$ pessoa

\footnotetext{
91 Para delimitar a área de concentração Princípios Norteadores, esta pesquisa buscou apoio nas funções da linguagem formuladas pelo linguista britânico Michael Halliday, a saber: funções ideacional, interpessoal e textual (GOUVEIA, 2009). Deste modo, os Princípios Norteadores envolvem aspectos interpessoais, que codificam significados de atitudes, interação e relações sociais; aspectos ideacionais, que remetem à dimensão representacional da linguagem e codificam significados associados à realidade (física ou mental); e aspectos textuais, que permitem a organização dos significados ideacionais e interpessoais em um todo linear e coerente. Assim, por exemplo, o princípio "Empatia" seria de ordem interpessoal; o princípio "Atenção às necessidades informacionais do usuário" seria de ordem ideacional e o princípio "Atenção às regras de acessibilidade" poderia ser vinculado à dimensão textual.
} 
sing/pl. Evitar: Jargão, Siglas e abreviaturas sem explicação, Termos técnicos sem explicação, Termos discriminatórios, Termos estrangeiros, Termos desnecessários/redundantes e Clichês/modismos/buzzwords.

- Construção de Frases - Preferir: Ordem direta, Forma afirmativa, Voz ativa, Frases curtas, Quebra de frases grandes em menores, Variação de tamanho das frases, Uma ideia por frase e Uso de conectores. Evitar: Estruturas complexas, Orações intercaladas, Duplas negativas, Sequências de substantivos e Nominalizações.

- Construção de Parágrafos: Curtos; Uma ideia por parágrafo.

- Ações de Avaliação: Métricas de leiturabilidade; Teste com usuários.

O Apêndice 1 indica como as 56 palavras-chave ${ }^{92}$ foram atribuídas às diretrizes dos onze governos.

O trabalho de categorização e agrupamento terminou com a tradução das diretrizes em inglês e espanhol para o português.

\section{4 .}

\section{Quadros de diretrizes por áreas de concentração}

A categorização das palavras-chave e o agrupamento por área possibilitaram elaborar quadros de diretrizes. É importante reiterar que os quadros compilam diretrizes mencionadas por dois ou mais governos - as diretrizes de incidência única foram descartadas. Procedeu-se assim pois o levantamento se propôs a categorizar as diretrizes mais recorrentes.

\subsection{1.}

\section{Princípios norteadores}

Dois governos não indicavam princípios norteadores nas diretrizes que foram compiladas para este levantamento documental. Entre os que indicam, o princípio mais recorrente foi "Objetividade". Em segundo lugar, empatados, vieram os princípios "Empatia com usuários", "Proximidade/Tom dialógico", “Adequação a

\footnotetext{
${ }^{92}$ Conforme já informado, o número 56 é o resultado das 83 palavras-chave iniciais subtraídas das
} 27 palavras-chave que tinham apenas uma incidência. 
padrões web", "Atenção às regras de acessibilidade" e "Atenção às necessidades informacionais do usuário". O Quadro 2 apresenta todas as ocorrências.

\begin{tabular}{|c|c|c|c|c|c|c|c|c|c|c|c|}
\hline \begin{tabular}{|l} 
PRINCÍPIOS \\
NORTEADORES
\end{tabular} & Austrália & Canadá & EUA & \begin{tabular}{|c|} 
Nova \\
Zelândia
\end{tabular} & $\begin{array}{l}\text { Reino } \\
\text { Unido }\end{array}$ & Chile & Colômbia & Portugal & Brasil & Ceará & $\begin{array}{l}\text { São } \\
\text { Paulo }\end{array}$ \\
\hline Empatia com usuários & - & - & - & & & & - & - & & & \\
\hline \begin{tabular}{|l} 
Proximidade/ \\
Tom dialógico
\end{tabular} & & & $\bullet$ & - & - & & - & & & - & \\
\hline Cordialidade & & & & & & & - & & & - & \\
\hline Autoridade & & & & - & - & & & & & & \\
\hline Respeito & & & & & & & - & & & - & \\
\hline Objetividade & - & - & - & - & - & - & - & & & & \\
\hline Transparência & & & & - & - & & - & & & & \\
\hline \begin{tabular}{|l|}
$\begin{array}{l}\text { Adequação aos } \\
\text { padrões web }\end{array}$ \\
\end{tabular} & - & - & - & - & & & - & & & & \\
\hline $\begin{array}{l}\text { Redução de esforço } \\
\text { cognitivo }\end{array}$ & - & & & - & & & - & & & & \\
\hline \begin{tabular}{|l|} 
Atenção às regras \\
de acessibilidade
\end{tabular} & - & - & - & - & & & - & & & & \\
\hline \begin{tabular}{|l|} 
Atenção às \\
necessidades \\
informacionais \\
do usuário
\end{tabular} & - & - & - & & & & - & - & & & \\
\hline
\end{tabular}

Quadro 2: Diretrizes governamentais de Linguagem Simples na área de concentração Princípios Norteadores

\subsection{2.}

\section{Estrutura da informação}

Cinco governos não tinham orientações sobre como estruturar a informação. As diretrizes de maior ocorrência - "Planejar antes de escrever" e "Uso de títulos/subtítulos" - tiveram apenas quatro menções cada. O Quadro 3 apresenta todas as ocorrências.

\begin{tabular}{|c|c|c|c|c|c|c|c|c|c|c|c|}
\hline $\begin{array}{l}\text { ESTRUTURA DA } \\
\text { INFORMAÇÃO }\end{array}$ & Austrália & Canadá & EUA & $\begin{array}{c}\text { Nova } \\
\text { Zelândia }\end{array}$ & $\begin{array}{l}\text { Reino } \\
\text { Unido }\end{array}$ & Chile & Colômbia & Portugal & Brasil & Ceará & $\begin{array}{l}\text { São } \\
\text { Paulo }\end{array}$ \\
\hline \begin{tabular}{|l|}
$\begin{array}{l}\text { Planejar antes } \\
\text { de escrever }\end{array}$ \\
\end{tabular} & & & - & & & & - & - & & - & \\
\hline \begin{tabular}{|l} 
Definição da estrutura \\
do texto \\
\end{tabular} & & & - & & & & - & - & & & \\
\hline Orientação para a tarefa & & - & - & & & & - & & & & \\
\hline Ordem lógica/ Fluxo & & & - & & & & - & & & & \\
\hline $\begin{array}{l}\text { Uso de pirâmide } \\
\text { invertida }\end{array}$ & & - & - & & & & & & & & \\
\hline Uso de titulos/subtitulos & & & - & & & & - & - & & & - \\
\hline $\begin{array}{l}\text { Segmentação conforme } \\
\text { o público }\end{array}$ & & & - & & & & & & & & \\
\hline
\end{tabular}

Quadro 3: Diretrizes governamentais de Linguagem Simples na área de concentração Estrutura da Informação 


\subsection{3.}

\section{Recursos visuais}

Três governos não tinham qualquer diretriz sobre o uso de recursos visuais. A orientação mais recorrente foi "Uso de marcadores para listar tópicos", sendo indicada por oito governos. O Quadro 4 apresenta todas as ocorrências.

\begin{tabular}{|c|c|c|c|c|c|c|c|c|c|c|c|}
\hline $\begin{array}{l}\text { RECURSOS } \\
\text { VISUAIS }\end{array}$ & Austrália & Canadá & EUA & $\begin{array}{c}\text { Nova } \\
\text { Zelândia }\end{array}$ & $\begin{array}{l}\text { Reino } \\
\text { Unido }\end{array}$ & Chile & Colômbia & Portugal & Brasil & Ceará & $\begin{array}{l}\text { São } \\
\text { Paulo }\end{array}$ \\
\hline Imagens & & & - & & & & - & & & - & \\
\hline Tabelas & & & - & & & & - & - & & & - \\
\hline Gráficos e infográficos & & & & & & & - & & & - & - \\
\hline Diagramas & & & & & & & - & - & & & - \\
\hline $\begin{array}{l}\text { Marcadores para listar } \\
\text { tópicos (bullet points) }\end{array}$ & & - & - & - & & • & - & - & & - & • \\
\hline $\begin{array}{l}\text { Alocação de espaços } \\
\text { em branco }\end{array}$ & & & • & & & & - & & & & \\
\hline $\begin{array}{l}\text { Divisão do texto } \\
\text { em pequenos blocos }\end{array}$ & & & - & & & & - & & & & \\
\hline $\begin{array}{l}\text { Coerência o uso de } \\
\text { tipografias e estilos }\end{array}$ & & & - & & & & - & & & & - \\
\hline
\end{tabular}

Quadro 4: Diretrizes governamentais de Linguagem Simples na área de concentração Recursos Visuais

\subsection{4.}

\section{Escolha de palavras}

Orientações relativas à seleção de palavras foi a área com a maior incidência de diretrizes. Nesse grupo estão incluídas desde recomendações relativas ao tamanho e familiaridade das palavras, a aspectos associados à morfologia da palavra com impacto para relação interpessoal, emprego de termos técnicos, etc. Todos os onze governos indicaram a diretriz "Preferir palavras familiares". Essa foi a única unanimidade em todo levantamento. A importância da familiaridade lexical foi reafirmada com a grande recorrência das diretrizes "Evitar o uso de jargão" (nove governos), "Evitar o uso de termos técnicos sem explicação" (oito governos), "Evitar o uso de siglas e abreviaturas sem explicação" (seis governos).

O Quadro 5 apresenta todas as ocorrências. 


\begin{tabular}{|c|c|c|c|c|c|c|c|c|c|c|c|}
\hline $\begin{array}{l}\text { ESCOLHA DE } \\
\text { PALAVRAS }\end{array}$ & Austrália & Canadá & EUA & $\begin{array}{l}\text { Nova } \\
\text { Zelândia }\end{array}$ & $\begin{array}{l}\text { Reino } \\
\text { Unido }\end{array}$ & Chile & Colômbia & Portugal & Brasil & Ceará & $\begin{array}{l}\text { São } \\
\text { Paulo }\end{array}$ \\
\hline $\begin{array}{l}\text { Lista com sugestão } \\
\text { de termos simplificados }\end{array}$ & $\bullet$ & & - & & - & & - & & & & \\
\hline \multicolumn{12}{|l|}{ Preferir } \\
\hline Familiares & - & - & - & - & - & - & - & - & - & - & - \\
\hline Concretas & & & - & & & & & & - & & \\
\hline Curtas & - & - & & - & - & & & & - & & \\
\hline Gênero neutro & & & & & & & & & - & & - \\
\hline $\begin{array}{l}\text { Pronomes na } \\
1^{\text {a }} \text { pessoa sing/plural }\end{array}$ & - & & - & - & & - & - & & & & \\
\hline \multicolumn{12}{|l|}{ Evitar } \\
\hline Jargão & - & - & - & - & - & & - & & - & - & - \\
\hline $\begin{array}{l}\text { Siglas e abreviaturas } \\
\text { sem explicação }\end{array}$ & & & - & & & & - & - & $\bullet$ & - & $\bullet$ \\
\hline $\begin{array}{l}\text { Termos técnicos } \\
\text { sem explicação }\end{array}$ & & - & - & & & - & - & - & • & - & • \\
\hline Termos discriminatórios & & & & & & & & & - & & - \\
\hline Termos estrangeiros & & & & & & & & & - & - & - \\
\hline $\begin{array}{l}\text { Termos desnecessários/ } \\
\text { redundantes }\end{array}$ & & - & $\bullet$ & & & • & - & • & & & \\
\hline $\begin{array}{l}\text { Clichês e modismos } \\
\text { (buzzwords) }\end{array}$ & & & 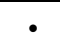 & & 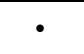 & & & & & & \\
\hline
\end{tabular}

Quadro 5: Diretrizes governamentais de Linguagem Simples na área de concentração Escolha de Palavras

\subsection{5.}

\section{Construção de frases}

Com exceção do Reino Unido, todos os governos ofereciam orientações sobre como construir frases. Dez governos que têm diretrizes de frases indicaram "Preferir frases curtas", sendo que a maioria dos governos recomendava uma quantidade média de palavras por frase (essa informação entra no quadro entre parênteses).

O Quadro 6 apresenta todas as ocorrências. 


\begin{tabular}{|c|c|c|c|c|c|c|c|c|c|c|c|}
\hline $\begin{array}{l}\text { CONSTRUÇÃO DE } \\
\text { FRASES }\end{array}$ & Austrália & Canadá & EUA & \begin{tabular}{|c|} 
Nova \\
Zelândia
\end{tabular} & $\begin{array}{l}\text { Reino } \\
\text { Unido }\end{array}$ & Chile & Colômbia & Portugal & Brasil & Ceará & $\begin{array}{l}\text { São } \\
\text { Paulo }\end{array}$ \\
\hline \multicolumn{12}{|l|}{ Preferir } \\
\hline Ordem direta & & - & - & & & & & & - & - & - \\
\hline Forma afirmativa & & - & - & & & - & - & & & & \\
\hline Voz ativa & - & - & - & - & & & - & - & - & - & \\
\hline Curtas & - & $\stackrel{\bullet}{\cdot}$ & - & $\begin{array}{c}\bullet \\
(15, \text { máx } 25)\end{array}$ & & - & $\dot{{ }_{(20)}}$ & $\underset{(20-30)}{\bullet}$ & $\dot{{ }_{(20)}}$ & - & $\dot{ }_{(20)}$ \\
\hline $\begin{array}{l}\text { Quebra de frases } \\
\text { grandes em menores }\end{array}$ & - & - & - & - & & & - & & - & & \\
\hline $\begin{array}{l}\text { Variação de tamanho } \\
\text { das frases } \\
\end{array}$ & & - & & - & & & & & & & \\
\hline Uma ideia por frase & & - & - & & & & - & & & & \\
\hline Uso de conectores & & & - & & & & & & & & \\
\hline \multicolumn{12}{|l|}{ Evitar } \\
\hline Estruturas complexas & & - & - & - & & & - & & & & \\
\hline Orações intercaladas & & & - & & & - & & & & & \\
\hline Duplas negativas & & - & - & & & & - & & & & \\
\hline \begin{tabular}{|l} 
Sequências de \\
substantivos
\end{tabular} & & - & - & & & & & & & - & \\
\hline Nominalizaçōes & & - & - & & & & - & & - & - & - \\
\hline
\end{tabular}

Quadro 6: Diretrizes governamentais de Linguagem Simples na área de concentração Construção de Frases

\subsection{6.}

\section{Construção de parágrafos}

Apenas seis governos ofereciam alguma indicação sobre essa área. Todos recomendaram parágrafos curtos. O Quadro 7 apresenta as ocorrências.

\begin{tabular}{|l}
\begin{tabular}{|l|c|c|c|c|c|c|c|c|c|c|c|}
\hline $\begin{array}{l}\text { CONSTRUÇão DE } \\
\text { PARÁGRAFOS }\end{array}$ & Austrália & Canadá & EUA & $\begin{array}{c}\text { Nova } \\
\text { Zelândia }\end{array}$ & $\begin{array}{c}\text { Reino } \\
\text { Unido }\end{array}$ & Chile & Colômbia & Portugal & Brasil & Ceará & $\begin{array}{c}\text { São } \\
\text { Paulo }\end{array}$ \\
\hline Preferir \\
\hline Parágrafos curtos & $\cdot$ & $\bullet$ & $\cdot$ & & & & $\bullet$ & $\cdot$ & & $\cdot$ & \\
\hline Uma idéia por parágrafo & & $\cdot$ & $\cdot$ & & & & $\cdot$ & & & & \\
\hline
\end{tabular}
\end{tabular}

Quadro 7: Diretrizes governamentais de Linguagem Simples na área de concentração Construção de Parágrafos

\subsection{7.}

\section{Ações de avaliação}


Apenas seis governos incluíram essa área entre as suas recomendações de Linguagem Simples. Todos recomendavam realizar testes com usuários dos textos. O Quadro 8 apresenta todas as ocorrências.

\begin{tabular}{|c|c|c|c|c|c|c|c|c|c|c|c|}
\hline $\begin{array}{l}\text { AÇÕES DE } \\
\text { AVALIAÇÃO }\end{array}$ & Austrália & Canadá & EUA & $\begin{array}{c}\text { Nova } \\
\text { Zelândia }\end{array}$ & $\begin{array}{l}\text { Reino } \\
\text { Unido }\end{array}$ & Chile & Colômbia & Portugal & Brasil & Ceará & $\begin{array}{l}\text { São } \\
\text { Paulo }\end{array}$ \\
\hline $\begin{array}{l}\text { Usar métricas de } \\
\text { leiturabilidade }\end{array}$ & $\bullet$ & $\bullet$ & & $\bullet$ & & & & & & & \\
\hline Testar com usuário & $\bullet$ & • & $\bullet$ & $\bullet$ & & & $\bullet$ & & & - & \\
\hline
\end{tabular}

Quadro 8: Diretrizes governamentais de Linguagem Simples na área de concentração Ações de Avaliação

\section{5 .}

\section{Lista das diretrizes governamentais mais recorrentes}

A última etapa do levantamento documental consistiu em compilar as diretrizes indicadas pela maioria dos governos, ou seja, diretrizes que foram indicadas por seis ou mais governos. Chegou-se a uma lista com doze diretrizes, apresentadas no Quadro 9.

\begin{tabular}{|l|l|c|}
\hline \multicolumn{1}{|c|}{$\begin{array}{c}\text { ÁREAS DE } \\
\text { CONCENTRAÇÃO }\end{array}$} & \multicolumn{1}{|c|}{$\begin{array}{c}\text { DIRETRIZES GOVERNAMENTAIS } \\
\text { DE LINGUAGEM SIMPLES }\end{array}$} & $\begin{array}{c}\text { No DE GOVERNOS } \\
\text { QUE INDICAM }\end{array}$ \\
\hline Princípios norteadores & Objetividade & 7 \\
\hline Recursos Visuais & Usar marcadores para listar tópicos & 8 \\
\hline Escolha de Palavras & Preferir palavras familiares & 11 \\
\hline Escolha de Palavras & Evitar jargão & 8 \\
\hline Escolha de Palavras & Evitar termos técnicos sem explicação & 6 \\
\hline Escolha de Palavras & Evitar siglas e abreviaturas sem explicação & 10 \\
\hline Construção de Frases & Preferir frases curtas & 8 \\
\hline Construção de Frases & Preferir voz ativa & 6 \\
\hline Construção de Frases & Quebrar frases grandes em menores & 6 \\
\hline Construção de Frases & Evitar nominalizações & 6 \\
\hline Construção de Parágrafos & Parágrafos curtos & 6 \\
\hline Ações de avaliação & Testar com usuários & 8 \\
\hline
\end{tabular}

Quadro 9: Doze diretrizes governamentais de Linguagem Simples mais recorrentes no levantamento, por área de concentração e número de governos que as indicam

A lista das 12 diretrizes de Linguagem Simples mais recorrentes em governos concluiu o levantamento documental. 


\section{6.}

\section{Discussão dos resultados do levantamento documental}

Objetivos alcançados - O levantamento documental alcançou os dois objetivos a que havia se proposto. Em primeiro lugar, possibilitou compor o panorama atual de como governos internacionais e nacionais têm recomendado o uso de Linguagem Simples em governo eletrônico (estado da arte). A partir das diretrizes coletadas em onze governos, constatou-se que o tema vem sendo trabalhado tanto em textos informativos dos portais de serviço como em processos de simplificação de trâmites conduzidos por setores de inovação. O levantamento identificou os responsáveis pela produção das diretrizes e verificou a medida em que há embasamento teórico nas orientações. Em segundo lugar, a sistematização e a categorização dos documentos coletados possibilitaram compor a lista das diretrizes mais recomendadas pelos governos. Assim, gerou-se o necessário parâmetro para reescrita do texto a ser usado no estudo experimental. O experimento será detalhado no próximo capítulo.

Variação de escopo - O levantamento mostrou ser grande a variação de escopo das diretrizes de Linguagem Simples recomendadas pelos governos. A variação parecia condicionada pelo contexto em os documentos se inseriam. Em países de língua inglesa, as diretrizes privilegiavam aspectos de redação do texto, pouco ou nada considerando a estrutura da informação ou o uso de recursos visuais. Tais aspectos do Design da Informação são discutidos em seções específicas nos guias voltados a padronizar os conteúdos dos portais daqueles países. Os documentos do governo federal brasileiro e do governo do Chile também se concentravam na redação e também estavam inseridos em guias que contemplavam diversos aspectos da produção de conteúdo. No documento de diretrizes do Reino Unido, a seção Plain English era ainda mais restrita - cobria somente palavras -, e outras seções encarregavam-se dos demais aspectos. Já na Colômbia e nos demais governos de língua portuguesa, as diretrizes tinham escopo mais amplo. Abarcavam desde questões conceituais, como o porquê de usar Linguagem Simples, até recomendações para estruturar a informação e fazer testes com usuários. É possível que a variação de escopo também esteja relacionada ao status da Linguagem Simples na comunicação governamental e à maturidade das plataformas de e-gov. 
'Reempacotamento' ou pertinência? - A Linguagem Simples constituiuse em inglês, sendo depois assimilada por outros idiomas, como mostrou o capítulo 4. Esse fato pode sugerir que, ao longo do tempo, tomou-se por base um conjunto de diretrizes que foram formuladas em culturas, idiomas e momentos históricos distintos para replicá-las em novas situações. O levantamento apontou que as diretrizes dos diversos países são parecidas e têm pouca variação: por vezes, parecem repetir a formulação em inglês. Uma avaliação apressada poderia concluir ter havido o mero "reempacotamento" das diretrizes originais, que teriam sido traduzidas e aplicadas nas novas sociedades sem considerar as particularidades de cada língua. Mas o capítulo 3 já apontou que os elementos linguísticos do burocratês são praticamente iguais em português, espanhol e inglês (vide Quadro 1). Se os problemas linguísticos são os mesmos, faz sentido que os recursos para os enfrentar sejam os mesmos. Deste modo, é pertinente haver recorrência das mesmas diretrizes nos vários países.

Enfrentamento dos problemas do burocratês - Uma análise comparativa entre as diretrizes mais recorrentes do levantamento documental (Quadro 9) e os problemas do burocratês apontados no capítulo 3 (Quadro 1) confirma haver correspondência direta entre diretrizes e problemas. Ou seja, todas as nove diretrizes de palavra, frase e parágrafo que foram mais recorrentes no levantamento enfrentam os elementos linguísticos prejudiciais à compreensibilidade.

Sintonia com fundamentação sobre compreensibilidade textual - Como já foi visto no capítulo 4, o movimento Plain Language formulou as suas diretrizes com pouca ou nenhuma participação de linguistas (RODRIGUES, 2013; BECKER, 2016). Ainda assim, as diretrizes categorizadas no levantamento mostraram ter total sintonia com as recomendações em prol da compreensibilidade textual não só de linguistas, mas também de ergonomistas e designers da informação. As diretrizes de Linguagem Simples procuram reduzir os custos de processamento mental, otimizar o uso da memória de trabalho e facilitar a computação sintática, contribuindo para a boa integração de informações durante a leitura. A Psicolinguística aponta que problemas nos processos de parsing sintático (análise da estrutura sintática das sentenças) e de seleção lexical podem trazer dificuldades para a leitura (PERFETTI, 1999; 2001). Neste sentido, foi interessante observar que o quadro "Escolha de palavras" foi o único do levantamento para o qual todos os onze documentos apontaram diretrizes. A lista final das diretrizes mais recorrentes 
no levantamento enfatizou a importância da escolha de palavras. Das doze diretrizes, quatro são sobre familiaridade lexical.

Em relação aos aspectos sintáticos, destacam-se os fatores associados à ordem de constituintes, complexidade estrutural e tamanho de frases. "Preferir frases curtas" foi uma orientação unânime entre os governos que indicaram diretrizes para a construção de frase. A maioria dos governos recomendava um número médio de palavras por frases. Vinte foi o número mais recorrente, sendo indicado por Colômbia, Brasil, São Paulo e Canadá ${ }^{93}$. O governo de Portugal indicava entre 20 e 30 palavras. Já o governo da Nova Zelândia sugeria uma média de 15 e um máximo de 25 palavras por frase.

Nos materiais que esta pesquisa coletou sobre o movimento Plain Language, considerando diversos idiomas, mostrou-se bastante recorrente a recomendação para escrever frases entre 15 e 20 palavras. Segundo Cutts (2013, p.2), a média 1520 palavras que o movimento adotou decorre do estudo feito por Kucera e Francis em 1967. Esse estudo fez um levantamento de corpus com cerca de um milhão de palavras ${ }^{94}$ procedentes de diversos tipos de textos produzidos nos Estados Unidos na década de 1960. As frases do corpus tinham tamanho médio de 19 palavras. Textos governamentais tinham uma média de 25 palavras por frase, a maior de todas. O estudo de Kucera e Francis foi uma referência durante décadas.

Vale considerar que a frequência das palavras é uma variável mais importante para o processamento mental do que o número de palavras por frase - o estudo de Kucera e Francis recebeu críticas neste sentido (BURGESS; LIVESAY, 1998; BRYSBAERT; NEW, 2009). Como já foi colocado na seção 2.4, conhecer o significado das palavras é central para a compreensão dos textos, pois reduz o tempo de decisão lexical. Palavras menos comuns tendem a ser mais difíceis de entender. Neste sentido, uma frase com 40 palavras frequentes no idioma pode ser mais fácil de ler e entender do que uma frase com 15 palavras raras.

Com relação ao tamanho médio de frases, estudos recentes com textos em inglês mostram uma tendência de queda, especialmente nos textos de noticário. Nos

\footnotetext{
${ }^{93}$ No Canadá, a média de 20 palavras por frase refere-se às diretrizes em inglês. Em francês, a recomendação canadense era de 24 palavras por frase. Os dois idiomas são oficiais no país. Todas as diretrizes canadenses são as mesmas em inglês e francês: a única diferença entre elas é essa indicação do número de palavras por frase.

${ }^{94} \mathrm{O}$ corpus tinha 1.014.000 palavras e foi compilado pela Brown University.
} 
anos 1960, textos de jornais tinham em média 18,2 palavras e nos anos 2000, a média caiu para 16,7 palavras (RUDNICKA, 2018). 


\section{Estudo experimental}

Este capítulo relata a segunda etapa da pesquisa: o estudo experimental para aferir a compreensibilidade de informações sobre o benefício Auxílio-doença do INSS. O experimento fundamentou-se nos conceitos de compreensibilidade textual (capítulo 2), burocratês (capítulo 3), Linguagem Simples (capí-tulo 4) e governo eletrônico (capítulo 5). Eram necessárias duas versões do texto, a original no site do INSS e uma versão reescrita usando a técnica Linguagem Simples. A reescrita considerou as diretrizes de Linguagem Simples mais recomendadas por governos que resultou do levantamento documental desta pesquisa (capítulo 6).

O experimento aferiu a compreensibilidade de aspectos verbais dos textos sobre o Auxílio-doença por adultos com pós-graduação. Conforme as razões já detalhadas na seção 1.6 (“Justificativa da relevância da pesquisa”), o foco da pesquisa foi em elementos linguísticos. Os aspectos visuais do texto foram controlados, assim como a organização da informação. Ou seja, a reescrita praticamente replicou a formatação do texto original. Não houve qualquer mudança no que diz respeito a tipo e tamanho de fonte, uso de cores ou imagens; tamanhos de linha e entrelinha ou justificação dos parágrafos. Foram apenas introduzidos bullet points.

Partiu-se do princípio que leitores de altíssima escolaridade e habituados com o gênero textual acadêmico teriam facilidade para compreender o burocratês. Assim, seria possível avaliar o impacto da reescrita de texto a partir de parâmetros de simplificação linguística na compreensibilidade textual e, consequentemente, na retenção de informações, entre leitores proficientes. Se a intervenção em Linguagem Simples gerasse impacto nessa faixa de escolaridade, a evidência da pesquisa seria mais robusta.

Além do experimento de compreensão sobre o texto do Auxílio-doença, os participantes responderam os seguintes questionários: 
- Avaliação do texto sobre o Auxílio-doença,

- Um eventual pedido do benefício para si;

- Interações prévias com o INSS;

- Avaliação de textos governamentais na internet;

- Avaliação de experiência recente de uso de serviços públicos digitais; e

- Perfil demográfico e hábitos de leitura. Foram coletados dados quantitativos e qualitativos.

O capítulo começará apresentando projeto do experimento, perfil e recrutamento de participantes, e materiais utilizados. O texto original e o texto simplificado serão analisados a partir de parâmetros de compreensibilidade. $\mathrm{O}$ capítulo prosseguirá descrevendo como foram os procedimentos de coleta e tratamento de dados. Apresentará as estatísticas descritivas, as análises inferenciais, a análise dos questionários e os dados qualitativos. Por fim, haverá a discussão dos resultados do experimento.

\section{1.}

\section{Projeto do experimento}

O projeto do experimento foi entre-sujeitos, com duas condições experimentais, cada condição submetida a um grupo de participantes, com mesmo perfil.

A variável independente foi o grau de complexidade textual. Essa variável foi manipulada para um grupo ler o texto sobre o benefício Auxílio-doença que consta do site do INSS (referido daqui em diante como Texto Burocratês) e o outro grupo ler o mesmo texto reescrito em Linguagem Simples (referido daqui em diante como Texto Simplificado). Os textos tinham aproximadamente o mesmo tamanho. Após a leitura, os participantes fizeram um teste de compreensão.

As variáveis dependentes do experimento foram:

- Número de acertos no teste de compreensão após a primeira leitura do texto;

- Número de releituras necessárias para conferir e/ou modificar as respostas;

- Tempo total para analisar e responder o teste de compreensão.

As variáveis controladas do experimento foram a organização da 
informação e aspectos visuais (o texto reescrito em Linguagem Simples replicou a formatação gráfica e tipográfica do texto original do INSS); e também o grau de escolaridade (todos os participantes tinham pós-graduação completa ou em curso).

Foram consideradas como variáveis intervenientes a atuação profisssional no setor público ou no campo do Direito - condições que tendem a facilitar o entendimento de textos em burocratês - e ter pedido benefício Auxílio-doença para si ou para terceiros. Buscou controlar tais interveniências o recrutar os participantes.

O projeto do experimento precisou ser adaptado às limitações impostas pela pandemia da Covid-19. O cronograma original da pesquisa previa realizar o estudo nos laboratórios da PUC-Rio no primeiro semestre de 2020. Esperava-se usar um rastreador ocular (eyetracker) para analisar diferenças no padrão de leitura dos grupos. O eyetracking era um objetivo antigo da pesquisadora, já constando do anteprojeto de ingresso no Mestrado. Mas a quarentena e o distanciamento social a partir de março de 2020 inviabilizaram o acesso ao campus durante o ano todo.

A pandemia exigiu criatividade e capacidade de adaptação. Originalmente, pretendia-se conhecer tanto o processo da leitura dos textos (rastreamento ocular) como o resultado da leitura (teste de compreensão). Com o impedimento de levar os participantes até o eyetracker da PUC-Rio, construiu-se uma metodologia alternativa centrada no resultado da leitura. As métricas tiveram que ser aferidas remotamente, por meio de uma videoconferência na plataforma Google Meet, com compartilhamento da tela dos sujeitos e cerca de 15 minutos de duração.

Além do teste de compreensão, para o qual as métricas de compreensibilidade aferíveis remotamente foram desenvolvidas, os participantes avaliaram a experiência de ler textos governamentais e usar serviços públicos na internet.

O desenho remoto exigiu mais tempo e maior capacidade de adaptação. Apesar das pressões inerentes à adaptação forçada, o objetivo da pesquisa (avaliar a diferença na compreensibilidade de textos nos diferentes estilos) manteve-se preservado.

O projeto da pesquisa foi aprovado pela Câmara de Ética em Pesquisa da PUC-Rio sob o protocolo 76/2020. O documento com o parecer positivo está no Anexo 2. 


\section{2.}

\section{Participantes do experimento}

O estudo experimental foi concebido para participantes com pós-graduação completa ou em curso. Escolheu-se esse recorte demográfico por ele proporcionar o melhor cenário possível no que diz respeito à habilidade de leitura relacionada a anos de escolaridade. Se a intervenção em Linguagem Simples gerasse impacto nessa faixa de escolaridade, a evidência da pesquisa seria mais robusta. E também porque a pesquisadora vem observando repetidas críticas de agentes públicos sobre o burocratês não causar problemas a leitores avançados. Se fosse provado que até os proficientes têm problemas com o burocratês, talvez esses agentes públicos percebessem que eles próprios achariam difícil entender a informação governamental se esse conteúdo não lhes fosse familiar. Talvez assim os normativos públicos em prol da clareza fossem mais disseminados. Mais detalhes sobre a crítica foram expostos na seção 4.4. (“Críticas ao movimento e à técnica”).

A pesquisa considerou que pessoas com um mínimo de quinze anos de escolaridade, com experiência de leitura e produção textual no meio acadêmico, têm aptidão para processar informação em textos longos e com estruturas linguísticas complexas. Por isso, foram recrutados participantes com pós-graduação stricto sensu (Mestrado/ Doutorado) ou lato sensu (Especialização/MBA), em curso ou completa, de diferentes campos do saber. Essa estratificação corresponde ao topo da pirâmide educacional brasileira, conforme foi discutido na seção 3.3 ("Habilidade da população brasileira para ler textos em burocratês").

Não foram encontradas fontes de referência oficiais que indicassem o número de pessoas no Brasil com pós-graduação lato sensu. Então, o cálculo da amostra partiu do universo de pessoas com mestrado, pois trata-se de um dado disponível em fontes oficiais, além de ser pré-requisito para o doutorado.

De acordo com relatório da OCDE, 0,8\% de brasileiros entre 25 e 64 anos têm mestrado (OECD, 2019, p. 2). Para chegar a um número aproximado a partir deste percentual, consultaram-se os dados populacionais do Censo Demográfico 2010 (IBGE CENSO 2010, s/d). O Censo indica que o número total de pessoas na 
faixa etária entre 25 e 64 anos é 96.505.964. Assim, nessa estimativa, o número de pessoas com mestrado no Brasil seria de $772.048^{95}$.

Como o universo de interesse do estudo era superior a 700 mil pessoas (população infinita), o número mínimo de participantes seria 30. Ao definir os grupos, esse número poderia ser aumentado

Além do critério "ter ou fazer pós-graduação", o recrutamento também considerou requisitos que controlassem as variáveis intervenientes: não trabalhar no setor público, não trabalhar no campo do Direito e nunca ter pedido o benefício Auxílio-doença para si ou para terceiros.

O recrutamento começou com a rede de contatos da pesquisadora, evitando quem já conhecia as linhas gerais do estudo. A abordagem inicial foi feita por Whatsapp. Várias pessoas declinaram participar da pesquisa alegando esgotamento por excesso de videoconferências ao longo do dia. O fenômeno ficou conhecido durante a pandemia como "fadiga de Zoom".

Durante a aplicação da pesquisa, alguns sujeitos disponibilizaram-se para indicar novos participantes (método bola de neve). No total, mais de 80 pessoas foram convidadas a participar da pesquisa e 64 aceitaram.

Os 64 que aceitaram receberam o Termo de Consentimento Livre e Esclarecido (TCLE) por email, pois a pandemia impediu a entrega do documento impresso em duas vias. O TCLE consta do Apêndice 2. A assinatura dos participantes foi coletada por meio de resposta positiva na troca de e-mails.

Diferentes motivos levaram a descartar 22 participações após os dados já terem sido coletados:

- Quatorze sujeitos leram o Texto Burocratês contendo uma palavra errada. Esse erro será comentado na seção 7.4.2 (Atividade experimental);

- Três sujeitos já conheciam as linhas gerais do estudo;

- Dois sujeitos tiveram problemas de conexão durante o experimento;

- Um sujeito era estrangeiro e falava mal português;

- Um sujeito mencionou trabalhar no setor público;

- Um sujeito estava ingerindo bebida alcoólica e fez comentários desconexos.

\footnotetext{
${ }^{95} \mathrm{O}$ valor exato do cálculo é $772.047,71$.
} 
Descartadas essas participações, foram contabilizados e analisados dados de 42 sujeitos. Destes, 27 faziam parte da rede de contatos da pesquisadora e quinze lhes eram desconhecidos.

Perfil dos participantes - Os 42 sujeitos foram alocados aleatoriamente nos grupos. O grupo que participou do experimento com o texto original, ou seja, leu o Texto Burocratês, tinha média de idade de 44 anos, com predominância do gênero feminino. A principal área de graduação era Ciências Sociais Aplicadas, com predominância de escolaridade no Mestrado. Os materiais de leitura mais frequente eram, empatados, leitura técnica, redes sociais e textos de trabalho.

Já no grupo Simplificado, a média de idade era de 47 anos, com predominância do gênero feminino. A principal área de graduação também era Ciências Sociais Aplicadas, com predominância de escolaridade em pós graduação lato sensu. O material de leitura mais frequente eram jornais. Os dados completos estão na Tabela 4.

\begin{tabular}{|c|c|c|}
\hline Dados dos participantes & Burocratês & Simplificado \\
\hline \multicolumn{3}{|l|}{ Idade } \\
\hline Média & 44 & 47 \\
\hline Valor máximo & 23 & 28 \\
\hline Valor mínimo & 60 & 58 \\
\hline Desvio padrão & 10,7 & 8,8 \\
\hline \multicolumn{3}{|l|}{ Gênero } \\
\hline Feminino & $57 \%$ & $57 \%$ \\
\hline Masculino & $43 \%$ & $38 \%$ \\
\hline Outros & - & $5 \%$ \\
\hline \multicolumn{3}{|l|}{ Escolaridade } \\
\hline MBA/Especialização cursando & - & $5 \%$ \\
\hline MBA/Especialização completo & $10 \%$ & $43 \%$ \\
\hline Mestrado cursando & $24 \%$ & $5 \%$ \\
\hline Mestrado completo & $29 \%$ & $14 \%$ \\
\hline Doutorado cursando & $19 \%$ & $10 \%$ \\
\hline Doutorado completo & $19 \%$ & $24 \%$ \\
\hline \multicolumn{3}{|l|}{ Área de graduação } \\
\hline Ciências Agrárias & $5 \%$ & - \\
\hline Ciências Biológicas & - & $5 \%$ \\
\hline Ciências da Saúde & $14 \%$ & $5 \%$ \\
\hline Ciências Exatas e da Terra & $10 \%$ & - \\
\hline Ciências Humanas & $10 \%$ & $24 \%$ \\
\hline Ciências Sociais Aplicadas & $48 \%$ & $52 \%$ \\
\hline Engenharia & $14 \%$ & - \\
\hline Linguística, Letras e Arte & - & $14 \%$ \\
\hline \multicolumn{3}{|l|}{ Principal material de leitura } \\
\hline Jornais & $10 \%$ & $38 \%$ \\
\hline Leitura técnica & $24 \%$ & $10 \%$ \\
\hline Livros de literatura & - & $10 \%$ \\
\hline Livros em geral de outros tipos & $14 \%$ & $19 \%$ \\
\hline Redes Sociais & $24 \%$ & $14 \%$ \\
\hline Revistas & $5 \%$ & $5 \%$ \\
\hline Textos de trabalho & $24 \%$ & $5 \%$ \\
\hline
\end{tabular}

Tabela 4: Perfil dos participantes do estudo experimental (grupos Burocratês e Simplificado) 
Quanto a interações prévias com o INSS, a maioria dos participantes dos dois grupos nunca acessou o site ou o aplicativo do órgão. A maioria nunca ligou para a central telefônica do INSS e nunca pediu benefício para si ou para terceiros. A Tabela 5 apresenta todos os resultados.

\begin{tabular}{lcc}
\hline $\begin{array}{l}\text { Tipos de interação } \\
\text { prévia com o INSS }\end{array}$ & Burocratês & Simplificado \\
\hline & & \\
Canais digitais INSS & $67 \%$ & $62 \%$ \\
Nunca acessou site ou app & $24 \%$ & $14 \%$ \\
Já acessou site & $5 \%$ & $14 \%$ \\
Já acessou app & $5 \%$ & $10 \%$ \\
Já acessou site e app & & \\
Central telefônica INSS & $81 \%$ & $81 \%$ \\
Nuncal ligou & $19 \%$ & $19 \%$ \\
Já ligou & & \\
Benefício para si ou para outras & & $81 \%$ \\
pessoas & $86 \%$ & $19 \%$ \\
Nunca pediu & $14 \%$ & \\
Já pediu & & \\
\end{tabular}

Tabela 5: Tipos de interação que os participantes do estudo experimental já haviam tido com o INSS (grupos Burocratês e Simplificado)

\section{3.}

\section{Materiais}

O experimento usou duas versões de um texto sobre o Auxílio-doença do INSS (Texto Burocratês e Texto Simplificado). Essas duas versões serão aqui analisadas a partir de perspectivas de compreensibilidade complementares.

O experimento consistiu em um teste para verificar como os participantes compreendiam e retinham as informações sobre o Auxílio-doença. Também foram aplicados questionários para avaliar a percepção dos participantes sobre textos governamentais online, sobre o uso de serviços públicos digitais e sobre um hipotético pedido do Auxílio-doença para si próprio. Os participantes responderam formulários com dados demográficos e experiências prévias com o INSS. Também leram um texto neutro, como medida de uniformização.

Com exceção do texto sobre o Auxílio-doença, que variava de acordo com a condição experimental, todos os materiais eram iguais nas duas condições experimentais. A interação dos participantes com os materiais se deu por meio da 
plataforma Google Forms. As próximas seções detalham como se deu a construção dos materiais.

\subsection{1}

\section{Texto do Auxílio-doença original no site do INSS (Texto Burocratês)}

O texto em torno do qual o experimento foi construído constava do site do INSS e trazia várias informações sobre a concessão do benefício Auxílio-doença. O Auxílio-doença tem caráter temporário e é devido ao segurado que fica incapacitado por motivo de doença (ANUÁRIO, 2019).

Há várias justificativas para a escolha específica desse texto:

- É representativo: O texto é um bom exemplo dos problemas de compreensibilidade textual que costumam estar presentes na informação pública em governo eletrônico.

- Tem peso quantitativo: Estatísticas conseguidas por meio da Lei de Acesso à Informação (E-SIC CGU, 2020) mostram que a página do Auxíliodoença é a mais visitada na seção "Benefícios" no site do INSS. Entre 29/07/2019 e 29/07/2020, recebeu 11.154.436 de visualizações, o que equivale a $34,63 \%$ do total da seção. A página foi acessada por 3.351.655 usuários. Igualmente superlativa é a quantidade anual dos benefícios concedidos. Entre junho de 2019 e junho de 2020, o INSS concedeu um total de 2.187.895 Auxílios-doença, somadas as modalidades "Por acidente" e "Previdenciário" (E-SIC CGU, 2020)

- É a principal demanda na Justiça Federal: O Auxílio-doença Previdenciário vem sendo o assunto de maior demanda na Justiça Federal nos últimos anos. Só em 2019, ingressaram 699.949 processos (PODER JUDICIÁRIO, 2020).

- Ganhou relevância com a ampliação de serviços remotos na pandemia: O fechamento das agências do INSS por vários meses, a partir de março de 2020, ampliou a oferta de serviços atendidos remotamente (INSS, 2020). Como foi já discutido, o autoatendimento online requer que a própria pessoa processe todas as etapas relacionadas ao trâmite digital e há poucas chances de esclarecer dúvidas pessoalmente. Então, a pandemia ampliou a relevância de analisar a compreensibilidade textual do Auxílio-doença. 
- Tem peso político: A Reforma da Previdência é um tópico central na sociedade brasileira da atualidade, com inúmeros desdobramentos políticos, econômicos e sociais. A população tem demonstrado dificuldade para entender as mudanças aprovadas em outubro de 2019, especialmente as novas fórmulas para calcular benefícios, caso do Auxílio-doença.

- Tem significado pessoal: Foi o primeiro texto governamental online a despertar a atenção da pesquisadora pela estrutura complexa da linguagem, três anos antes do ingresso no Mestrado.

O texto sobre o Auxílio-doença no site do INSS continha várias seções, daí ter sido necessário delimitar uma delas para conduzir o experimento. Foi escolhida a seção "Benefícios concedidos ou reativados por decisão judicial" - como já exposto, o Auxílio-doença judicial é o assunto mais demandado na Justiça Federal brasileira. A seção era autocontida e sem links, ou seja, trazia todas as informações necessárias para entender o conteúdo. $\mathrm{O}$ texto tinha quatro parágrafos e 1.210 caracteres com espaço, incluindo o título:

\section{Benefícios concedidos ou reativados por decisão judicial}

O benefício de auxílio-doença concedido ou reativado por decisão judicial cessará na data determinada pelo juiz ou, quando não houver esta determinação na sentença, após 120 dias contados da implantação ou reativação do benefício (Lei 8.213/1991, alterada pela Lei 13.457/2017).

Nos últimos 15 dias do benefício de auxílio-doença concedido/reativado judicialmente, caso julgue que o prazo inicialmente concedido para a recuperação se revelou insuficiente para retorno ao trabalho, o segurado poderá solicitar a prorrogação do benefício pela Central 135, internet ou comparecendo em uma agência do INSS.

No dia da perícia médica do pedido de prorrogação ou da revisão do benefício, o segurado deverá apresentar documento de identificação oficial com foto, que permita o reconhecimento do requerente, e toda a documentação médica relacionada à doença/lesão.

O benefício de auxílio-doença concedido/reativado judicialmente será cessado na data determinada pela sentença ou pela lei, caso o(a) segurado(a) ou seu representante não solicitem a prorrogação nos últimos 15 dias do benefício, através da Central 135, internet ou comparecendo em uma agência do INSS. ${ }^{96}$

\footnotetext{
${ }^{96}$ Disponível em https://www.gov.br/inss/pt-br/saiba-mais/auxilios/auxilio-doenca/auxilio-doenca. Acesso em: 04 jan. 2020
} 
A Figura 8 reproduz o texto conforme constava no site do INSS, que fica abrigado dentro do portal de serviços Gov.br.

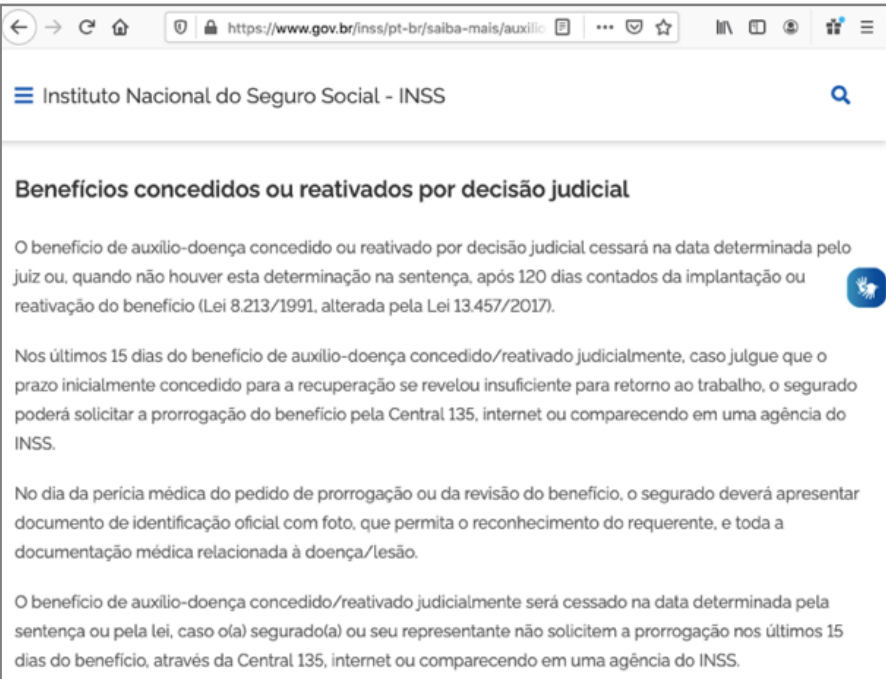

Figura 8: Seção "Benefícios concedidos ou reajustados por decisão judicial", conforme constava no site do INSS

A proposta do experimento - aferir a diferença na compreensão textual de informações sobre um serviço público digital antes e depois da reescrita em Linguagem Simples -, tornou essencial analisar as características linguísticas do texto original do INSS. A análise geraria subsídios para a reescrita do texto em Linguagem Simples.

Assim sendo, o texto foi analisado sob duas perspectivas complementares, que serão apresentadas a seguir:

- a partir das diretrizes de Linguagem Simples mais recorrentes em governos conforme levantamento documental apresentado no capítulo 6;

- a partir dos elementos linguísticos característicos do burocratês que foram apresentados no capítulo 3;

Além da análise de características linguísticas, foi realizada uma análise complementar usando métricas da ferramenta computacional Coh-Metrix Port 3.0. 


\subsubsection{1.}

\section{Análise de complexidade}

O Texto Burocratês começou sendo examinado conforme a lista das 12 diretrizes governamentais de Linguagem Simples mais recorrentes no levantamento documental, apresentadas na seção 6.5.

Tendo em vista o contexto do experimento, a pesquisadora considerou que algumas diretrizes daquela lista das mais recorrentes poderiam ser descartadas. São elas:

- Diretriz "Objetividade" (Princípios Norteadores): O levantamento documental não indicou marcadores concretos para o princípio da Objetividade, dificultando a adoção dessa diretriz.

- Diretriz "Evitar jargão" (Escolha de palavras): O levantamento documental não indicou marcadores concretos do que deve ser considerado jargão, dificultando a adoção dessa diretriz.

- Diretriz "Evitar termos técnicos sem explicação" (Escolha de palavras): Considerou-se que a diretriz "Preferir palavras familiares", contemplada na lista das mais recorrentes, já englobaria o caso dos termos técnicos.

- Diretriz "Evitar siglas e abreviaturas sem explicação" (Escolha de palavras): O Texto Burocratês só tinha uma sigla, a do INSS. Dado o cenário do experimento (quando o participante era informado que leria um texto sobre o Auxilio-doença do INSS), a pesquisadora achou desnecessário explicar a sigla.

- Diretriz "Quebra de frase grandes em menores" (Construção de Frases): Considerou-se que a diretriz "Preferir frases curtas", contemplada na lista das mais recorrentes, já englobaria a quebra em frases menores.

- Diretriz "Parágrafos curtos" (Construção de Parágrafos): A estrutura do texto não comportava a aplicação dessa diretriz, pois os parágrafos eram curtos, ainda que fossem formados por períodos longos - condição já coberta pela diretriz "Preferir frases curtas", que seria utilizada;

- Diretriz "Teste com usuários" (Ações de Avaliação): O experimento não previa coletar opiniões dos participantes e implementá-las em novas versões do texto, daí a diretriz não ser aplicável; 
Por outro lado, a pesquisadora considerou relevante incluir duas diretrizes que ficaram fora da lista das mais recorrentes. A pesquisadora levou em conta a sua perspectiva de linguagem, que é congruente com os conceitos de compreensibilidade apresentados no capítulo 2. Deste modo, foram incluídas as seguintes diretrizes:

- Princípios Norteadores - Diretriz "Proximidade/ Tom dialógico":

- Construção de Frases - Diretriz "Preferir ordem direta": A ordem direta facilita a computação sintática ${ }^{97}$, aliviando a sobrecarga na memória de trabalho.

O Quadro 10 lista as sete diretrizes selecionadas do levantamento documental para analisar o Texto Burocratês.

\begin{tabular}{|l|l|c|}
\hline \multicolumn{1}{|c|}{$\begin{array}{c}\text { ÁREAS DE } \\
\text { CONCENTRAÇÃO }\end{array}$} & \multicolumn{1}{|c|}{$\begin{array}{c}\text { DIRETRIZES GOVERNAMENTAIS } \\
\text { DE LINGUAGEM SIMPLES }\end{array}$} & $\begin{array}{c}\text { No DE GOVERNOS } \\
\text { QUE AS INDICA }\end{array}$ \\
\hline Princípios Norteadores & Proximidade/ Tom dialógico & 5 \\
\hline Recursos Visuais & Usar marcadores para listar tópicos & 8 \\
\hline Escolha de Palavras & Preferir palavras familiares & 11 \\
\hline Construção de Frases & Preferir frases curtas & 8 \\
\hline Construção de Frases & Preferir voz ativa & 5 \\
\hline Construção de Frases & Preferir ordem direta & 6 \\
\hline Construção de Frases & Evitar nominalizações & 10 \\
\hline
\end{tabular}

Quadro 10: Sete diretrizes governamentais de Linguagem Simples oriundas do levantamento documental que foram selecionadas para analisar o Texto Burocratês

As sete diretrizes governamentais de Linguagem Simples possibilitaram compor um check-list e avaliar os parágrafos do Texto Burocratês. Os resultados são apresentados no Quadro 11.

O check-list apontou a grande incidência de elementos que são contrários às diretrizes governamentais de Linguagem Simples.

97 O processo de parsing, isto é, de atribuir à sentença que se lê uma estrutura sintática, exige manter na memória representações das estruturas, de modo a integrar nelas as informações e recuperar o sentido da sentença. Decorre daí que, em princípio, a extensão de uma sentença é diretamente proporcional ao volume de informações a serem integradas e ao custo de tal processo para a memória de trabalho do leitor, cuja capacidade é limitada.. 


\begin{tabular}{|l|c|c|c|c|}
\hline CHECK-LIST DE DIRETRIZES & PARÁGRAFO 1 & PARÁGRAFO 2 & PARÁGRAFO 3 & PARÁGRAFO 4 \\
\hline $\begin{array}{l}\text { Estabelece proximidade usando tom } \\
\text { dialógico? }\end{array}$ & Não & Não & Não & Não \\
\hline $\begin{array}{l}\text { Usa marcadores para listar tópicos } \\
\text { bullet points)? }\end{array}$ & Não & Não se aplica & Não & Não se aplica \\
\hline As palavras são familiares? & Não & Não & Não & Não \\
\hline As frases são curtas? & Não & Não & Não & Não \\
\hline $\begin{array}{l}\text { As frases estão na voz ativa e evitam } \\
\text { estruturas passivas? }\end{array}$ & Não & Não & Não & Não \\
\hline As frases estão na ordem direta? & Não & Não & Não & Não \\
\hline $\begin{array}{l}\text { Há nominalizaçães que podem ser } \\
\text { transformadas em verbos? }\end{array}$ & Sim & Sim & Sim & Sim \\
\hline
\end{tabular}

Quadro 11: Diagnóstico do Texto Burocratês conforme diretrizes governamentais de Linguagem Simples

Verificada a incidência dos elementos contrários às diretrizes governamentais de Linguagem Simples, o passo seguinte foi fazer uma análise dos elementos linguísticos do burocratês que dificultam a leitura do Texto Burocratês a cada parágrafo. Esses elementos já foram discutidos na seção 3.2..

No primeiro parágrafo, um longo sujeito tem núcleo (“benefício”) modificado por sintagmas variados, entre os quais há até mesmo formas reduzidas de passiva ("concedido ou reativado por decisão judicial”), que acarretam um elevado grau de complexidade estrutural. No mesmo trecho encontra-se ainda uma oração adverbial intercalada ("quando não houver ... sentença") e, no final do período, há um particípio que se refere a um termo de difícil recuperação ("alterada pela Lei...).

No segundo parágrafo, "Nos últimos 15 dias ... judicialmente", adjunto adverbial de tempo que pertence à oração principal (“o segurado poderá solicitar... INSS"), surge anteposto a esta e dela apartado (pela oração condicional "caso julgue... trabalho"), o que sobrecarrega o processamento e pode dificultar a compreensão. O custo de tal construção para a memória de trabalho do leitor é elevado por diversas razões, entre elas o fato de o verbo "julgar" aparecer na primeira linha do parágrafo e seu sujeito (“o segurado") só se dar a conhecer na terceira.

O terceiro parágrafo é carregado de nominalizações, o que tem exige do leitor maior nível de abstração conceitual. 
No quarto parágrafo, com seu período de extensão notavelmente longa, observa-se ainda um grande número de estruturas passivas, identificadas pelos particípios "concedido/reativado", “cessado", "determinada".

A análise linguística sinalizou a grande quantidade de elementos que podem dificultar a leitura e a compreensão do Texto Burocratês.

\title{
7.3.1.2.
}

\section{Análise complementar de complexidade, usando a ferramenta Coh-Metrix Port 3.0}

A ferramenta online Coh-Metrix-Port 3.0 $0^{98}$ é uma adaptação para o português brasileiro do CohMetrix, ferramenta computacional que usa Processamento Natural de Linguagem para extrair 46 métricas indicativas de coerência de texto, auxiliares à análise de compreensibilidade.

Enquanto as fórmulas clássicas de leiturabilidade avaliam a dificuldade dos textos considerando apenas o tamanho de palavras e o tamanho de frases, o CohMetrix trabalha com relações de coesão, conhecimento de mundo, aspectos de linguagem e características discursivas.

\begin{abstract}
A coesão é uma propriedade objetiva da linguagem e do texto. Há características explícitas, palavras, frases ou sentenças que guiam o leitor na interpretação das idéias essenciais no texto, na conexão de idéias com outras idéias e na conexão de idéias com unidades globais de nível superior (por exemplo, tópicos e temas). Estes dispositivos coesivos orientam o leitor sobre como formar uma representação coerente $^{99}$. (GRAESSER et. al, 2004)
\end{abstract}

A ferramenta original foi criada na Universidade de Memphis, nos Estados Unidos. A versão em português foi desenvolvida por pesquisadores do NILCNúcleo Interinstitucional de Linguística Computacional da Universidade de São Paulo, na cidade de São Carlos (SCARTON E ALUÍSIO, 2010). Como o nome indica, trata-se da terceira versão da ferramenta em português.

A Figura 9 mostra a página inicial do Coh-Metrix Port 3.0 no site do NILC.

\footnotetext{
${ }_{98}$ Disponível em: http://fw.nilc.icmc.usp.br:23380/cohmetrixport

${ }^{99}$ Original em inglês: Cohesion is an objective property of the explicit language and text. There are explicit features, words, phrases, or sentences that guide the reader in interpreting the substantive ideas in the text, in connecting ideas with other ideas, and in connecting ideas to higher level global units (e.g., topics and themes). These cohesive devices cue the reader on how to form a coherent representation.
} 


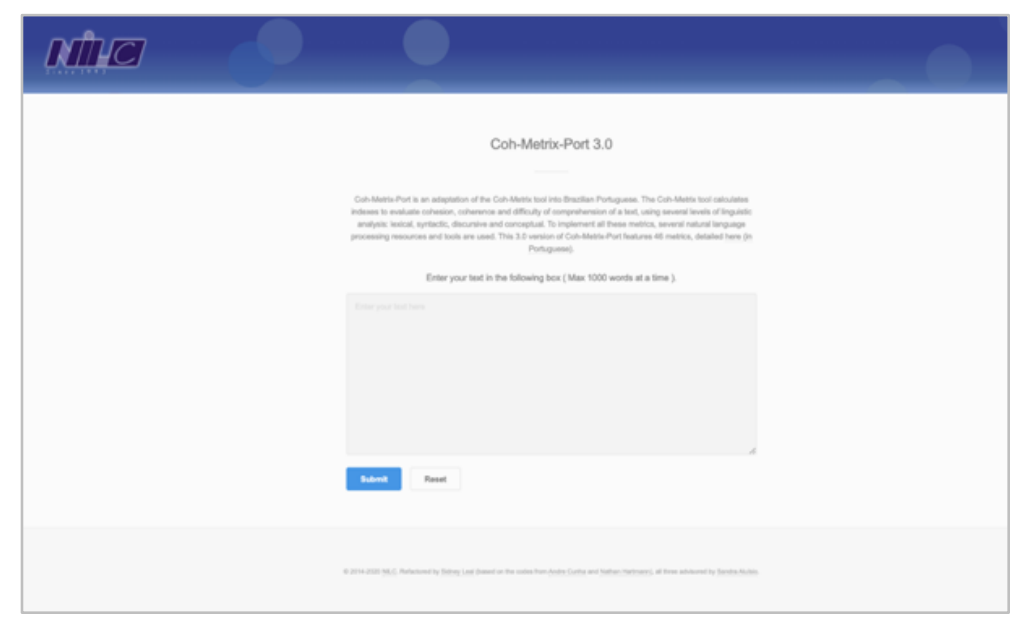

Figura 9: Página inicial da ferramenta computacional Coh-Metrix-Port 3.0 no site do NILC

Das 46 métricas disponíveis no Coh-Metrix Port 3.0, foram selecionadas quatro métricas para uso no estudo experimental com o texto do Auxílio-doença.

Foram escolhidas métricas que abordam aspectos ligados ao tamanho de sentenças e períodos, um fator que pode representar custo para o processamento e consequentemente para a compreensão - devido à necessidade de manter a informação na memória de trabalho durante a computação sintática. Seguem as métricas selecionadas para este estudo, suas descrições (D) e interpretações (I) conforme constam da plataforma:

- Média de palavras por sentença: (D) Número de palavras dividido pelo número de sentenças/ (I) Quanto maior a métrica, maior a complexidade textual.

- Palavras antes de verbos principais: (D) Quantidade média de palavras antes dos verbos principais das orações principais das sentenças/ (I) Quanto maior a métrica, maior a carga de memória exigida e maior a complexidade textual. ${ }^{100}$

\footnotetext{
${ }^{100}$ Exemplo de contagem fornecido pelo Coh-Metrix Port: "O acessório polêmico entrou no projeto, de autoria do senador Cícero Lucena (PSDB-PB), graças a uma emenda aprovada na Comissão de Educação do Senado em outubro.” Esta sentença tem três orações, sendo uma principal (receberão), uma subordinada adverbial condicional (aprovada) e uma subordinada adjetiva explicativa reduzida de particípio (completados). São 8 palavras antes da oração principal, considerando a vírgula (se, a, ideia, for, aprovada, “,”, os, estudantes).
} 
- Sílabas por palavra de conteúdo: (D) Número médio de sílabas por palavras de conteúdo (substantivos, verbos, adjetivos e advérbios) no texto/ (I) Quanto maior o número de sílabas por palavras, maior a complexidade textual.

- Índice de Leiturabilidade de Flesch (Flesch Readability Index): Esse índice foi formulado originalmente em inglês por Rudolf Flesch nos anos 1940. Estabelece correlação entre tamanhos médios de palavras e sentenças com a facilidade de leitura. A pontuação varia de zero a 100 e tem relação com grau de escolaridade. O Coh-Metrix-Port 3.0 usa a fórmula adaptada para o português por Martins et al. (1996). Essa adaptação foi realizada antes do normativo federal de 2006 que ampliou a educação básica de oito para nove anos no Brasil. Deste modo, o índice em português considera a antiga $8^{\mathrm{a}}$ série, e não o atual $9^{\circ}$ ano.

\section{0-25: Muito difícil (Textos acadêmicos)}

25-50: Pouco difícil (Ensino Médio e Nível superior)

50-75: Fácil (da $5^{\mathrm{a}}$ à $8^{\mathrm{a}}$ série)

75-100: Muito fácil (corresponde aos primeiros quatro anos de escolaridade)

Cada parágrafo do Texto Burocratês (sem o título) foi processado isoladamente no Coh-Metrix Port 3.0 ${ }^{101}$. Os valores estão no Quadro 12. A interpretação dos resultados vem logo a seguir.

\begin{tabular}{|c|c|c|c|c|}
\hline MÉTRICAS DO COH-METRIX PORT 3.0 & PARÁGRAFO 1 & PARÁGRAFO 2 & PARÁGRAFO 3 & PARÁGRAFO 4 \\
\hline Média de palavras por sentença & 40 & 46 & 38 & 46 \\
\hline Média de palavras antes de verbos principais & 4 & 11 & 18 & 7 \\
\hline Média de sílabas por palavra de conteúdo & 3,1 & 3,8 & 3,9 & 3,3 \\
\hline Índice Flesch & $\begin{array}{c}3 \\
\text { (muito difícil) }\end{array}$ & $\begin{array}{c}-29 \\
\text { (muito difícil) }\end{array}$ & $\begin{array}{c}-12,3 \\
\text { (muito difícil) }\end{array}$ & $\begin{array}{c}-5,5 \\
\text { (muito difícil) }\end{array}$ \\
\hline
\end{tabular}

Quadro 12: Diagnóstico do Texto Burocratês no Coh-Metrix Port 3.0, por parágrafos

${ }^{101} \mathrm{O}$ processamento foi realizado em $06 / 01 / 2021$. 
Média de palavras por sentença: $O$ levantamento documental do capítulo 6 apontou que a maioria das diretrizes governamentais recomenda escrever frases com um número médio de 20 palavras. Todos os parágrafos do Texto Burocratês são formados por um único período longo que excede tal número, chegando a ser maiores do que o dobro. Os parágrafos 2 e 4 são frases com 46 palavras.

Média de palavras antes de verbos principais: Índice relevante para avaliar a carga da memória de trabalho, aspecto que foi abordado no capítulo 2. O Texto Burocratês apresentou médias elevadas nesta métrica, especialmente no terceiro parágrafo, que tinha 18 palavras antes do verbo principal.

Média de sílabas por palavra de conteúdo: Acessar palavras longas no léxico mental demanda mais esforço cognitivo. Todos os parágrafos do Texto Burocratês tiveram médias superiores a três sílabas.

Índice Flesch: Todos os parágrafos do Texto Burocratês pontuaram no nível "muito difícil", sendo três parágrafos com resultados negativos. Pontuação negativa indica uma dificuldade superior ao nível "muito difícil, que vai de zero a 25.

A análise na ferramenta Coh-Mextrix Port 3.0 apontou um alto grau de complexidade do Texto Burocratês.

\subsection{2.}

\section{Texto do Auxílio-doença reescrito em Linguagem Simples (Texto Simplificado)}

As análises dos fatores que podem afetar a compreensibilidade do Texto Burocratês geraram parâmetros para orientar a reescrita do texto do Auxíliodoença.

É preciso considerar que os parâmetros sugerem critérios para identificar elementos linguísticos que dificultam a leitura. Sempre haverá outros fatores a considerar na escrita de um texto, tais como público-alvo, suporte da mensagem ou objetivo da comunicação. A aplicabilidade simultânea dos parâmetros também requer cautela. Alguns ou vários podem ser descabidos no contexto de uso.

Também é importante considerar que todo processo de escrita implica em escolhas lexicais, sintáticas e semânticas que são individuais. As escolhas sempre irão variar em função de quem escreve, independentemente de haver um conjunto 
de parâmetros a orientar o processo. No caso do Texto Simplificado, nem todas as escolhas de redação seguiram o que as análises apontaram. Por exemplo: algumas frases na ordem indireta permaneceram assim, pois a pesquisadora julgou que o recurso enfatizava a informação deslocada; e optou-se por usar marcadores para tópicos só no primeiro parágrafo, apesar ser possível aplicá-los em outros trechos.

Primeira versão da reescrita - Manteve-se a estrutura original em quatro parágrafos, bem como o conteúdo de cada parágrafo, contribuindo para o paralelismo das versões antes e depois. A organização da informação foi replicada uma vez que o foco desta pesquisa é o estilo textual, só sendo redistribuída a informação que trata do representante. No Texto Burocratês, essa informação é mencionada no último parágrafo; na reescrita, aparece no segundo parágrafo.

O corpo do texto seguiu os parâmetros estabelecidos, mas o título foi reescrito de forma livre. A pesquisadora é jornalista e procurou manter a natureza sintética dos títulos, que dificilmente têm verbos e artigos. A palavra "Benefícios" do título foi substituída pela expressão "Prazos e prorrogação do Auxílio-doença". Isso ocorreu porque "Benefícios" é um termo genérico, enquanto "Auxílio-doença" era o termo exato para aquele contexto. As palavras "concedido" e "reativado" foram mantidas no título (e também no texto), pois são os termos precisos do vocabulário previdenciário.

Validação por painel de especialistas - Como Pettersson (2012, p. 105) recomenda, "quando projetamos informações e material de aprendizagem, é muito importante que os materiais sejam revisados e aprovados por pessoas com conhecimento especializado nas áreas apropriadas." 102 Deste modo, a primeira versão do Texto Simplificado foi validada por um painel de três advogados especialistas em Direito Previdenciário, montado especialmente para a pesquisa. Os especialistas fizeram a revisão técnica do Texto Simplificado em julho e agosto de 2020. Suas identidades serão preservadas. Seguem os dados que os qualificam:

- Especialista 1 - Graduou-se em Direito em 2003. Tem 18 anos de experiência em Direito Previdenciário. Cargos já assumidos: Chefia de Benefício em agência do INSS. Diretoria do Instituto Brasileiro de Direito Previdenciário.

\footnotetext{
102 Original em inglês: When we design information and learning material, it is very important that
} the materials are reviewd and approved by people with expert knowledge in the appropriate fields. 
- Especialista 2 - Graduou-se em Direito em 1998. Tem 15 anos de experiência em Direito Previdenciário. Cargos já assumidos: Orientação de Direito Previdenciário no Núcleo de Prática Jurídica da PUC-Rio.

- Especialista 3 - Graduou-se em Direito em 1997. Tem 23 anos de experiência em Direito Previdenciário. Cargos já assumidos: Presidência da Comissão de Previdência Social da OAB-RJ. Presidência da Comissão de Seguridade Social do Instituto dos Advogados Brasileiros. Filiação benemérita ao Instituto Brasileiro de Direito Previdenciário.

O painel foi solicitado a criticar a primeira versão da reescrita, considerando que o texto destinava-se ao cidadão comum, desconhecedor das regras previdenciárias. Ou seja, o painel devia evitar linguagem especializada ao indicar os ajustes. Cada especialista revisou o texto sozinho, sem consultar os demais membros do painel. Sugestões de ajustes eram enviadas diretamente para a pesquisadora. Foram sugeridas mudanças que reintroduziram voz passiva e nominalização ${ }^{103}$. Os pedidos foram acatados, já que o objetivo do painel de advogados era garantir a precisão técnica do texto. Na seção 8.1.5 ( "O que poderia ter sido diferente"), será feita uma auto-crítica sobre a dinâmica de trabalho que foi proposta ao painel de especialistas.

Versão final da reescrita simplificada - Todos os ajustes indicados pelos especialistas foram implementados, gerando uma segunda versão da reescrita, que lhes foi novamente enviada para revisão. O painel aprovou o texto de forma unânime, sem restrições. O Texto Simplificado ficou com 974 caracteres com espaço (incluindo título):

\section{Prazos e prorrogação do Auxílio-doença concedido ou reativado por decisão judicial}

Um benefício decidido na justiça termina:

. 120 dias após a data em que o INSS implantar ou reativar o benefício, ou . no prazo que o juiz indicar na sentença.

A regra está na lei 8.213/1991, que foi alterada pela lei 13.457/2017.

\footnotetext{
${ }^{103}$ FRASE 1 - A reescrita original sem estrutura passiva era: "A foto tem que dar para reconhecer você". A reescrita final com a voz passiva ficou "A foto deve estar boa e permitir que você seja reconhecido pelo servidor". FRASE 2 - A reescrita original sem nominalização era "Caso esse tempo seja pouco para se recuperar e voltar ao trabalho...”. A reescrita final com nominalização ficou "Caso esse tempo seja pouco para sua recuperação e volta ao trabalho...".
} 
Caso esse tempo seja pouco para sua recuperação e volta ao trabalho, você ou um representante pode pedir para prorrogar o auxílio-doença. $\mathrm{O}$ pedido de prorrogação só pode ser feito nos últimos 15 dias do benefício. Use a central telefônica 135, a internet ou vá a uma agência do INSS.

Os pedidos para prorrogar ou rever auxílio-doença exigem perícia. No dia da perícia, leve toda a documentação médica sobre a sua doença ou lesão. Leve também um documento de identidade oficial com foto. A foto deve estar boa e permitir que você seja reconhecido pelo servidor.

Se você não pedir a prorrogação, o seu auxílio-doença terminará na data estabelecida inicialmente.

É importante reiterar que todo processo de escrita implica em escolhas lexicais, sintáticas e semânticas que são individuais e, de certa forma, condicionadas pelo contexto da situação. As diretrizes de Linguagem Simples não são uma fórmula única. A versão final da reescrita poderia ter optado por estruturas diferentes. Por exemplo, o trecho "caso esse tempo seja pouco para a sua recuperação e volta ao trabalho" poderia ter sido reescrito como "Se você precisar de mais tempo para se recuperar e voltar ao trabalho". A opção pela passiva nesse caso foi motivada pela intenção de manter o tópico da trecho anterior, que era o tempo para término do benefício (Um benefício decidido na justiça termina:. 120 dias após a data em que o INSS implantar ou reativar o benefício, ou. no prazo que o juiz indicar na sentença.). Nesse caso, portanto, a opção de manter a passiva foi determinada pela intenção de facilitar a manutenção temática e, desse modo, a retomada da informação.

O Quadro 13 apresenta o Texto Burocratês, as intervenções propostas pela reescrita e a versão final do Texto Simplificado, parágrafo a parágrafo. 


\begin{tabular}{|c|c|c|}
\hline TEXTO BUROCRATÊS & INTERVENÇÕES DA REESCRITA & TEXTO SIMPLIFICADO \\
\hline $\begin{array}{l}\text { O benefício de auxílio-doença concedido } \\
\text { ou reativado por decisão judicial cessará } \\
\text { na data determinada pelo juiz ou, } \\
\text { quando não houver esta determinação } \\
\text { na sentença, após } 120 \text { dias contados da } \\
\text { implantação ou reativação do benefício } \\
\text { (Lei } 8.213 / 1991 \text {, alterada pela Lei } \\
\text { 13.457/2017). }\end{array}$ & $\begin{array}{l}\text { - Quebra do período longo em menores } \\
\text { - Uso de marcadores para listar opções } \\
\text { - Substituição do verbo "cessar" por } \\
\text { outro mais familiar } \\
\text { - Eliminação da oração intercalada } \\
\text { - Eliminação das nominalizações } \\
\text { "decisão", "implantação" e "reativação }\end{array}$ & $\begin{array}{l}\text { Um benefício decidido na justiça termina: } \\
\text {. } 120 \text { dias após a data em que o INSS implantar } \\
\text { ou reativar o benefício, ou } \\
\text {. no prazo que o juiz indicar na sentença. } \\
\text { A regra está na lei } 8.213 / 1991 \text {, que foi alterada } \\
\text { pela lei } 13.457 / 2017 \text {. }\end{array}$ \\
\hline $\begin{array}{l}\text { Nos últimos } 15 \text { dias do benefício de } \\
\text { auxílio-doença concedido/reativado } \\
\text { judicialmente, caso julgue que o prazo } \\
\text { inicialmente concedido para a } \\
\text { recuperação se revelou insuficiente para } \\
\text { retorno ao trabalho, o segurado poderá } \\
\text { solicitar a prorrogação do benefício pela } \\
\text { Central } 135 \text {, internet ou comparecendo } \\
\text { em uma agência do INSS. }\end{array}$ & $\begin{array}{l}\text { - Quebra do período longo em menores } \\
\text { - Uso de tom dialógico } \\
\text { - Eliminação de orações intercaladas } \\
\text { - Eliminar a nominalização "retorno" } \\
\text { - Substituição dos termos "julgue", } \\
\text { "concedido para a recuperação" e } \\
\text { "insuficiente" por outros mais } \\
\text { familiares }\end{array}$ & $\begin{array}{l}\text { Caso esse tempo seja pouco para sua } \\
\text { recuperação e volta ao trabalho, você ou um } \\
\text { representante pode pedir para prorrogar o } \\
\text { auxílio-doença. O pedido de prorrogação só } \\
\text { pode ser feito nos últimos } 15 \text { dias do benefício. } \\
\text { Use a central telefônica } 135 \text {, a internet ou vá a } \\
\text { uma agência do INSS. }\end{array}$ \\
\hline $\begin{array}{l}\text { No dia da perícia médica do pedido de } \\
\text { prorrogação ou da revisão do benefício, } \\
\text { o segurado deverá apresentar } \\
\text { documento de identificação oficial com } \\
\text { foto, que permita o reconhecimento do } \\
\text { requerente, e toda a documentação } \\
\text { médica relacionada à doença/lesão. }\end{array}$ & $\begin{array}{l}\text { - Quebra do período longo em menores } \\
\text { - Uso de tom dialógico } \\
\text { - Uso de ordem direta } \\
\text { - Eliminação das nominalizações } \\
\text { "revisão" e "reconhecimento" } \\
\text { - Substituição dos termos "segurado" } \\
\text { e "requerente" por outros mais } \\
\text { familiares }\end{array}$ & $\begin{array}{l}\text { Os pedidos para prorrogar ou rever auxilio- } \\
\text { doença exigem perícia. No dia da perícia, leve } \\
\text { toda a documentação médica sobre a sua } \\
\text { doença ou lesão. Leve também um documento } \\
\text { de identidade oficial com foto. A foto deve estar } \\
\text { boa e permitir que você seja reconhecido pelo } \\
\text { servidor. }\end{array}$ \\
\hline $\begin{array}{l}\text { O benefício de auxílio-doença } \\
\text { concedido/reativado judicialmente será } \\
\text { cessado na data determinada pela } \\
\text { sentença ou pela lei, caso o(a) } \\
\text { segurado(a) ou seu representante não } \\
\text { solicitem a prorrogação nos últimos } 15 \\
\text { dias do benefício, através da Central } \\
135, \text { internet ou comparecendo em uma } \\
\text { agência do INSS }\end{array}$ & $\begin{array}{l}\text { - Quebra do período longo em menores } \\
\text { - Uso de tom dialógico } \\
\text { - Troca da voz passiva pela voz ativa } \\
\text { - Substituição dos termos "cessado" e } \\
\text { "solicitem" por outros mais familiares }\end{array}$ & $\begin{array}{l}\text { Se você não pedir a prorrogação, o seu auxilio- } \\
\text { doença terminará na data estabelecida } \\
\text { inicialmente. }\end{array}$ \\
\hline
\end{tabular}

Quadro 13: Texto Burocratês, intervenções feitas na reescrita e Texto Simplificado, parágrafo por parágrafo

\subsubsection{1}

\section{Check-list de complexidade: Texto Simplificado e Texto Burocratês}

O Texto Simplificado foi submetido a um check-list de complexidade composto por 11 parâmetros foram usados para analisar o Texto Burocratês:

- Sete diretrizes governamentais de Linguagem Simples oriundas do levantamento documental apresentado no capítulo 6 .

- Quatro métricas da ferramenta automática Coh-Metrix Port 3.0

Vale observar que a métrica "Média de palavras por sentença" do Coh-Metrix e a diretriz governamental "Preferir frases curtas" referem-se ao mesmo elemento linguístico (tamanho de frase). Ambas foram mantidas, pois considerou-se o valor 
calculado pelo Coh-Metrix Port 3.0 como uma informação complementar à diretriz governamental.

O Quadro 14 apresenta o check-list comparativo entre o Texto Simplificado e o Texto Burocratês:

\begin{tabular}{|c|c|c|c|c|c|c|}
\hline $\begin{array}{l}\text { ORIGEM DO } \\
\text { PARÂMETRO }\end{array}$ & PARÂMETRO & $\begin{array}{l}\text { TIPO DE } \\
\text { TEXTO }\end{array}$ & PARÁGRAFO 1 & PARÁGRAFO 2 & PARÁGRAFO 3 & PARÁGRAFO 4 \\
\hline \multirow{2}{*}{$\begin{array}{l}\text { Coh-Metrix } \\
\text { Port } 3.0\end{array}$} & \multirow{2}{*}{$\begin{array}{l}\text { Média de palavras } \\
\text { por sentença }\end{array}$} & Burocratês & 40 & 46 & 38 & 46 \\
\hline & & Simplificado & 6,8 & 16,6 & 11,5 & 14 \\
\hline \multirow{2}{*}{$\begin{array}{l}\text { Coh-Metrix } \\
\text { Port } 3.0\end{array}$} & \multirow{2}{*}{$\begin{array}{l}\text { Média de palavras } \\
\text { antes de verbos principais }\end{array}$} & Burocratês & 4 & 11 & 18 & 7 \\
\hline & & Simplificado & 1,3 & 2 & 2,5 & 4 \\
\hline \multirow{2}{*}{$\begin{array}{l}\text { Coh-Metrix } \\
\text { Port } 3.0\end{array}$} & \multirow{2}{*}{$\begin{array}{l}\text { Média de sílabas } \\
\text { por palavra de conteúdo }\end{array}$} & Burocratês & 3,1 & 3,8 & 3,9 & 3,3 \\
\hline & & Simplificado & 2,4 & 2,7 & 2,9 & 3,8 \\
\hline \multirow{2}{*}{$\begin{array}{l}\text { Coh-Metrix } \\
\text { Port } 3.0\end{array}$} & \multirow{2}{*}{ Índice Flesch } & Burocratês & 3 (muito difícil) & -29 (muito difícil) & $-12,3$ (muito dificil) & $-5,5$ (muito difícil) \\
\hline & & Simplificado & 87,1 (muito fácil) & 55,9 (fácil) & 45,8 (pouco difícil) & 4,9 (muito difícil) \\
\hline \multirow{2}{*}{$\begin{array}{l}\text { Diretrizes } \\
\text { Governamentais }\end{array}$} & \multirow{2}{*}{$\begin{array}{l}\text { Estabelece proximidade } \\
\text { usando tom dialógico? }\end{array}$} & Burocratês & Não & Não & Não & Não \\
\hline & & Simplificado & Não & Sim & Sim & Sim \\
\hline \multirow{2}{*}{$\begin{array}{l}\text { Diretrizes } \\
\text { Governamentais }\end{array}$} & \multirow{2}{*}{$\begin{array}{l}\text { Usa marcadores para listar } \\
\text { tópicos (bullet points)? }\end{array}$} & Burocratês & Não & Não se aplica & Não & Não se aplica \\
\hline & & Simplificado & Sim & Não se aplica & Não & Não \\
\hline \multirow{2}{*}{$\begin{array}{l}\text { Diretrizes } \\
\text { Governamentais }\end{array}$} & \multirow{2}{*}{ As palavras são familiares? } & Burocratês & Não & Não & Não & Não \\
\hline & & Simplificado & Em parte & Sim & Sim & Sim \\
\hline \multirow{2}{*}{$\begin{array}{l}\text { Diretrizes } \\
\text { Governamentais }\end{array}$} & \multirow{2}{*}{ As frases são curtas? } & Burocratês & Não & Não & Não & Não \\
\hline & & Simplificado & Sim & Sim & Sim & Sim \\
\hline \multirow{2}{*}{$\begin{array}{l}\text { Diretrizes } \\
\text { Governamentais }\end{array}$} & \multirow{2}{*}{$\begin{array}{l}\text { As frases estão na voz } \\
\text { ativa e evitam estruturas } \\
\text { passivas? }\end{array}$} & Burocratês & Não & Não & Não & Não \\
\hline & & Simplificado & Em parte & Em parte & Sim & Sim \\
\hline \multirow{2}{*}{$\begin{array}{l}\text { Diretrizes } \\
\text { Governamentais }\end{array}$} & \multirow{2}{*}{$\begin{array}{l}\text { As frases estão na ordem } \\
\text { direta? }\end{array}$} & Burocratês & Não & Não & Não & Não \\
\hline & & Simplificado & Sim & Em parte & Em parte & Não \\
\hline \multirow{2}{*}{$\begin{array}{l}\text { Diretrizes } \\
\text { Governamentais }\end{array}$} & \multirow{2}{*}{$\begin{array}{l}\text { Há nominalizações que } \\
\text { podem ser transformadas } \\
\text { em verbos? }\end{array}$} & Burocratês & Sim & Sim & Sim & Sim \\
\hline & & Simplificado & Não & Em parte & Não & Em parte \\
\hline
\end{tabular}

Quadro 14: Check-list comparativo de complexidade entre os textos Simplificado e Burocratês

\subsection{3.}

\section{Texto usado como medida de uniformização}

Para verificar se haveria diferença no tempo que os participantes levavam para ler um texto, foi realizada uma atividade somente de leitura, sem tarefa de compreensão, antes do teste. Os participantes leram um texto neutro, desvinculado do experimento, mas dentro da mesma área temática. $\mathrm{O}$ texto foi retirado da seção de perguntas frequentes sobre o Regime Geral da Previdência, no site do INSS. Era um parágrafo com cinco frases e 530 caracteres com espaço. Todos os sujeitos leram o texto em voz alta: 
Todo o trabalhador com carteira assinada é automaticamente filiado à Previdência. Quem trabalha por conta própria precisa se inscrever e contribuir mensalmente para ter acesso aos benefícios previdenciários. São segurados da Previdência Social os empregados, os empregados domésticos, os trabalhadores avulsos, os contribuintes individuais e os trabalhadores rurais. Até mesmo quem não tem renda própria, como as donas de casa e os estudantes, pode se inscrever na Previdência Social. Para se filiar é preciso ter mais de 16 anos. (MINISTÉRIO DA ECONOMIA, s/d)

\subsection{4.}

\section{Texto do cenário experimental}

Cenários experimentais propiciam maior engajamento na leitura e maior envolvimento dos participantes com a tarefa proposta. Assim sendo, foi elaborado o seguinte cenário para contextualizar a situação de leitura do texto sobre Auxíliodoença:

\footnotetext{
Um amigo ficou doente e só recebeu o auxílio-doença do INSS porque entrou na Justiça. O benefício já está perto de acabar, mas ele ainda não se recuperou.

O seu amigo precisa saber como prorrogar o benefício. Ele pediu para você ajudar, lendo as informações no site do INSS. Leia com atenção, pois você responderá a perguntas sem consultar o texto.
}

Os participantes liam o texto do INSS que lhes era atribuído (Texto Burocratês ou Texto Simplificado, por alocação aleatória) acreditando que fariam apenas uma leitura do texto para responder o teste de compreensão.

Como será explicado na seção 7.4 .2 ("Atividade experimental”), os participantes eram informados sobre a possibilidade de reler o texto somente após terem completado o teste. A quantidade de acertos na primeira leitura e o número de releituras para ajustar ou conferir respostas eram variáveis dependentes do experimento

\subsection{5.}

\section{Teste para verificar a compreensão e retenção das informações}

Todos os sujeitos fizeram o mesmo teste para avaliar a compreensão do texto e o grau de retenção das informações. O teste consistia em 12 afirmativas sobre 
tópicos envolvendo o texto lido: término do Auxílio-doença, prorrogação do benefício e dia da perícia médica. Ou seja, havia 4 afirmativas em cada tópico. $\mathrm{O}$ participante devia marcar as afirmativas que julgasse corretas. Cada afirmativa valia um ponto. Assim, a nota máxima do teste era 12.

Procurou-se redigir as afirmativas usando estruturas semelhantes, para facilitar a leitura. Para evitar operações matemáticas na afirmativa sobre o prazo do pedido de prorrogação, usou-se uma data fácil de calcular ( $1^{\circ}$ de outubro).

O painel de especialistas também fez a revisão técnica das doze afirmativas e do gabarito das respostas do teste. Todos os ajustes pedidos foram implementados.

Leia as frases abaixo EM SILENNCIO. Marque todas que achar corretas. Você pode marcar várias.

SOBRE O TÉRMINO DO AUXÍLIO-DOENÇA (marque todas que achar corretas) ( ) O juiz definiu o prazo. Nesse caso, o auxílio-doença terminará 120 dias após a data da sentença.

( ) O juiz não definiu prazo. Nesse caso, o auxílio-doença dura 120 dias a partir da data em que o INSS implantou ou reativou o benefício.

( ) O juiz pode definir um prazo. Nesse caso, o auxílio-doença termina na data que o juiz indicar.

( ) Algumas leis proíbem que a sentença do juiz fique sem prazo.

SOBRE A PRORROGAÇÃO DO BENEFÍCIO (marque todas que achar corretas) ( ) Um representante pode pedir para prorrogar o benefício em nome do seu amigo. ( ) O benefício do seu amigo termina em 15 de outubro. Logo ele pode pedir prorrogação a partir de $1^{\circ}$ de outubro.

( ) O seu amigo tem que consultar a sentença judicial para saber qual é o prazo de prorrogação do benefício.

( ) A prorrogação pode ser pedida até 15 dias após o benefício terminar.

SOBRE O DIA DA PERÍCIA MÉDICA (marque todas que achar corretas)

( ) O seu amigo deve levar toda a documentação médica sobre a doença dele.

( ) Se o seu amigo levar um documento de identidade com foto antiga ou muito diferente da aparência dele agora, ele pode ter problemas para fazer a perícia e conseguir a prorrogação.

( ) Se o seu amigo for acompanhado à perícia, ele deve levar a documentação do representante dele.

( ) A perícia pode ser marcada nas agências do INSS, mas não pela internet ou pela Central 135.

A Figura 10 mostra como o teste foi apresentado aos participantes no experimento. 


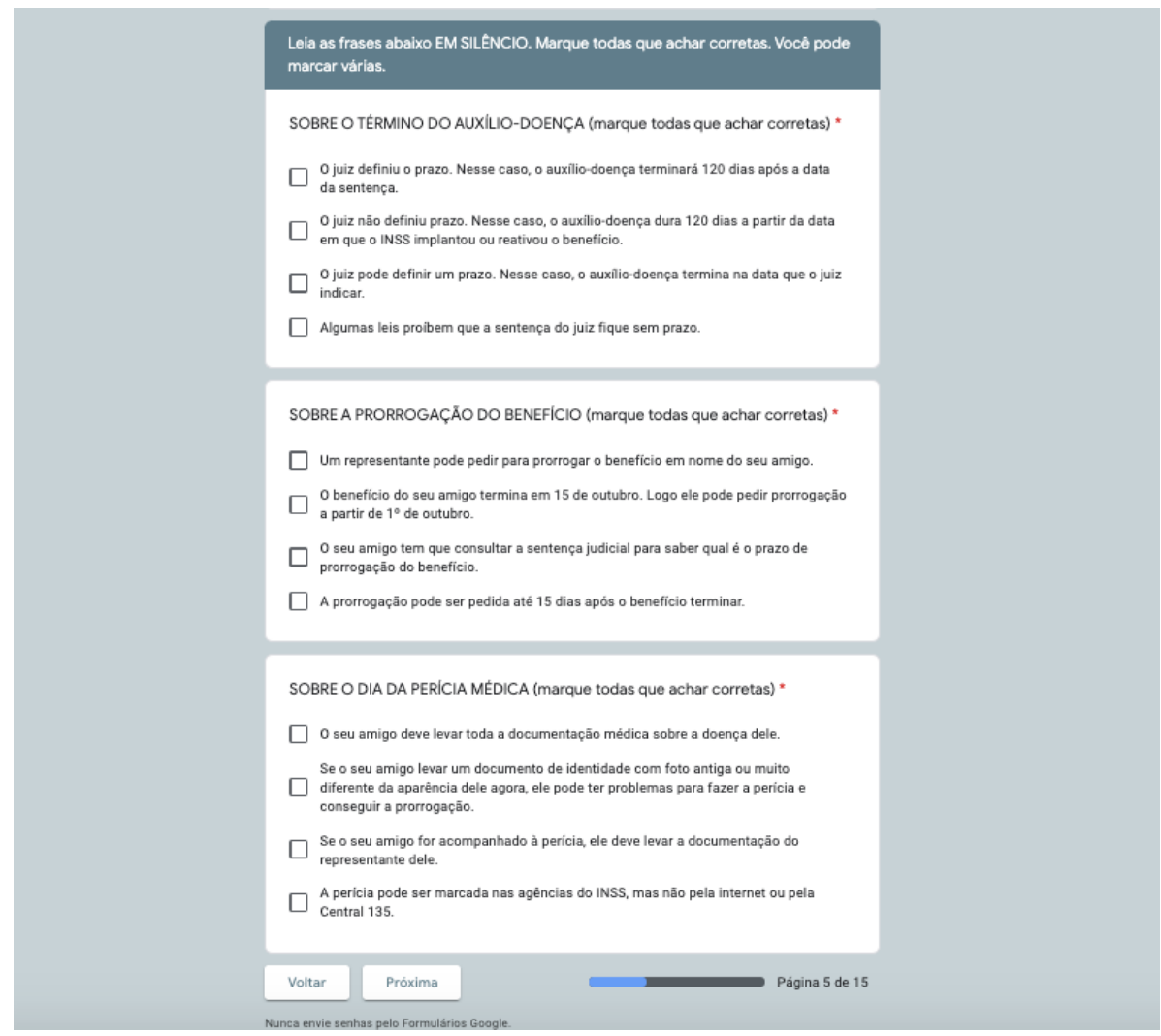

Figura 10: Tela do teste do estudo experimental para verificar compreensão e retenção de informações

O Apêndice 3 apresenta os critérios que orientaram a elaboração das afirmativas do teste.

\subsection{6.}

\section{Questionários}

Findo o teste de compreensão, os participantes eram solicitados a responder os seguintes questionários:

- Avaliação do texto sobre o Auxílio-doença;

- Eventual pedido de Auxílio-doença para si;

- Avaliação de textos governamentais na internet;

- Avaliação de experiência recente de uso de serviços públicos digitais,

- Dados demográficos e perfil de leitura

- Interações prévias com o INSS 
A seguir, será apresentado o conteúdo de cada questionário.

\section{Avaliação do texto sobre o Auxílio-doença}

Se você fosse conversar com o seu amigo agora, como agiria?

Eu conversaria com base nessas informações que acabei de ler

Eu buscaria mais informações

Sua opinião sobre o texto

De zero a 10, que nota você dá para as informações do texto do INSS, considerando a dificuldade de compreensão?

0 - Fácil de compreender

10 - Difícil de compreender

Após a primeira leitura, você sentiu confiança em ter recebido as informações necessárias?

Sim

Não

Na sua opinião, alguma parte do texto poderia ter sido exposta de modo mais claro?

Comente em voz alta.

\section{Eventual pedido de Auxílio-doença para si}

Se você ficasse doente e precisasse pedir o Auxílio-doença, como agiria?

Eu faria o pedido pelo site ou pelo aplicativo do INSS, pois as informações lá disponíveis são suficientes.

1 Discordo totalmente

7 Concordo totalmente

Eu pediria a alguém de minha confiança para ler as informações no site do INSS e conversaria com ela antes de pedir.

1 Discordo totalmente

7 Concordo totalmente

Eu faria o pedido pela central telefônica do INSS, pois só um funcionário do próprio órgão pode prestar todos os esclarecimentos.

1 Discordo totalmente

7 Concordo totalmente

Eu contrataria um advogado ou despachante para cuidar do meu pedido de Auxíliodoença, pois prefiro não lidar com a burocracia.

1 Discordo totalmente

7 Concordo totalmente

\section{Avaliação de textos governamentais na internet}

Como você avalia textos governamentais na internet?

As informações em sites e aplicativos governamentais costumam ser confusas e difíceis de entender. 
1 Discordo totalmente

7 Concordo totalmente

Eu percebo nesses textos que existe a preocupação em facilitar a vida dos usuários.

1 Discordo totalmente

7 Concordo totalmente

Quando preciso de informação sobre algum serviço governamental, consulto apenas o site do órgão.

1 Discordo totalmente

7 Concordo totalmente

Vou ao Google para buscar mais informações em sites independentes.

1 Discordo totalmente

7 Concordo totalmente

\section{Avaliação de experiência recente de uso de serviços públicos digitais}

Sobre o uso de serviços públicos na internet

Você visitou algum site de governo nos últimos 6 meses? Por exemplo: buscou informações oficiais sobre a pandemia, fez Imposto de Renda, emitiu certidões, acessou Detran, usou plataformas de universidades públicas etc.

Sim

Não

Cite dois adjetivos que descrevem essa experiência.

\section{Dados demográficos e perfil de leitura}

Algumas informações sobre você

A sua identidade será tratada com padrões profissionais de sigilo.

Qual é o seu primeiro nome? (campo aberto para digitação)

Qual é o seu gênero?

Feminino

Masculino

Outros

Prefiro não informar

Qual é a sua idade? (campo aberto para digitação)

Qual é o seu grau de escolaridade?

Especialização/ MBA em curso

Especialização/ MBA completo

Mestrado em curso

Mestrado completo

Doutorado em curso

Doutorado completo

Em que área você trabalha? (campo aberto para digitação) 
Qual é o seu principal material de leitura? MARQUE SÓ UMA OPÇÃO. Essas categorias valem para digital e impresso.
Jornais
Revistas
Livros de literatura
Livros em geral de outros tipos
Leitura técnica
Histórias em quadrinho
Textos de trabalho
Áudio-livros
Redes sociais

Quando o experimento já havia sido concluído, mostrou-se necessário registrar a área de graduação dos sujeitos, que não constava do questionário de dados demográficos. Essa informação foi buscada na plataforma Lattes, no Google, em redes sociais ou perguntando diretamente aos participantes.

\section{Interações prévias com o INSS}

Você e o INSS

Você já acessou o site do INSS ou o aplicativo Meu INSS?

Sim, o site

Sim, o aplicativo Meu INSS

Sim, já acessei os 2

Nunca acessei

Você já telefonou para a Central 135 do INSS em busca de informações?

Sim

Não

Você já pediu algum benefício do INSS para você ou para outra pessoa? Por exemplo: aposentadoria, pensão ou salário-maternidade.

Sim (fale EM VOZ ALTA o benefício que você já pediu)

Não

O objetivo do questionário sobre interações prévias com o INSS era verificar o grau de familiaridade com o modus operandi previdenciário e, consequentemente, com a linguagem ali usada. E também possibilitou verificar se o sujeito não havia mesmo pedido o Auxílio-doença, pois este era um critério de exclusão no recrutamento. 


\section{4}

\section{Procedimentos}

Previamente à atividade experimental, foi realizado um teste piloto, no qual foram aplicadas cinco condições experimentais. Os procedimentos empregados na atividade experimental serão detalhadamente descritos na seção 7.4.2.

\subsection{1}

\section{Teste-piloto}

O teste-piloto foi realizado nas mesmas condições do experimento: videochamada gravada no Google Meet, formulário online, compartilhamento de tela do participante e alocação aleatória de sujeitos nas condições experimentais.

Foram identificados problemas surgidos da pouca familiaridade dos participantes com o Google Meet, tais como dificuldade para compartilhar a tela, ligar o som ou usar o chat. $\mathrm{O}$ teste antecipou algumas das interferências que o home office produz, como interrupções para atender demandas da casa ou ruídos de familiares no mesmo ambiente

O teste-piloto possibilitou reformular enunciados e perguntas que geraram dúvidas. Por exemplo, nas perguntas sobre uso de serviços públicos digitais, os dois primeiros participantes não entenderam o significado do enunciado "Você usou serviços públicos na internet nos últimos seis meses?’. O enunciado foi trocado para "Você visitou algum site de governo nos últimos meses?", mas nem assim o participante seguinte compreendeu do que se tratava. Ao serem acrescidos alguns exemplos de sites de órgãos governamentais, os participantes posteriores entenderam.

\subsection{2}

\section{Atividade experimental}

Após concordar com o Termo de Consentimento Livre e Esclarecido e devolvido o documento assinado, os participantes recebiam por Whatsapp um link 
para a plataforma de agendamento de reuniões chamada Calendly ${ }^{104}$ para marcar a videochamada.

A marcação poda ser feita entre os dias 10 e 24 de setembro de 2020, das $9 \mathrm{~h}$ às 20h, a cada meia hora. Após escolher o horário de sua conveniência, o participante recebia um email automático com o link do Google Meet para acessar a videochamada. Algumas horas antes do horário agendado, a pesquisadora enviava um Whatsapp para lembrar. As notificações do Calendly e o lembrete contribuíram para não haver faltas ou atrasos. Alguns sujeitos precisaram reagendar o horário, mas o fizeram previamente. Todos estavam online na hora marcada.

Ao ingressar na videochamada, o participante recebia pelo chat do Google Meet um link para acessar o formulário com os materiais do experimento. $\mathrm{O}$ participante abria o formulário no seu navegador e compartilhava a tela com a pesquisadora. Os menos familiarizados com o Google Meet levavam alguns minutos até se acertarem - houve quem pedisse ajuda a membros da família. A videoconferência só começava a ser gravada após o compartilhamento da tela ser efetivado.

O experimento iniciava com a leitura em voz alta do texto usado como medida de uniformização (seção 7.3.3.). A seguir, o participante lia em silêncio o cenário do experimento (seção 7.3.4.). Depois, lia em voz alta a versão do texto Auxíliodoença aleatoriamente alocada: Texto Burocratês (seção 7.3.1.) ou Texto Simplificado (seção 7.3.2.). O objetivo era verificar aspectos do padrão de leitura dos grupos, tais como diferença no tempo de pausas e na retomada de sentenças. Após ler o texto do Auxílio-doença em voz alta, o participante relia silenciosamente.

Seguia-se o teste para verificar compreensão e retenção de informações (seção 7.3.5.). A pesquisadora dizia: “Agora, vem um conjunto de afirmativas sobre o texto que você leu. Marque todas que achar corretas. Você pode marcar várias". Tal instrução vocal mostrou-se necessária durante o teste-piloto, pois a maioria das pessoas não percebia ser possível marcar várias respostas corretas e marcavam apenas uma. Durante o teste, quando alguém fazia perguntas de compreensão, a pesquisadora permanecia calada. Não havia limite de tempo para fazer o teste. Ao

${ }^{104}$ Disponível em: https://calendly.com. Acesso em: 4 jan. 2020 
terminar, o participante era informado sobre a possibilidade de reler o texto para ajustar ou confirmar as suas respostas (Figura 11).

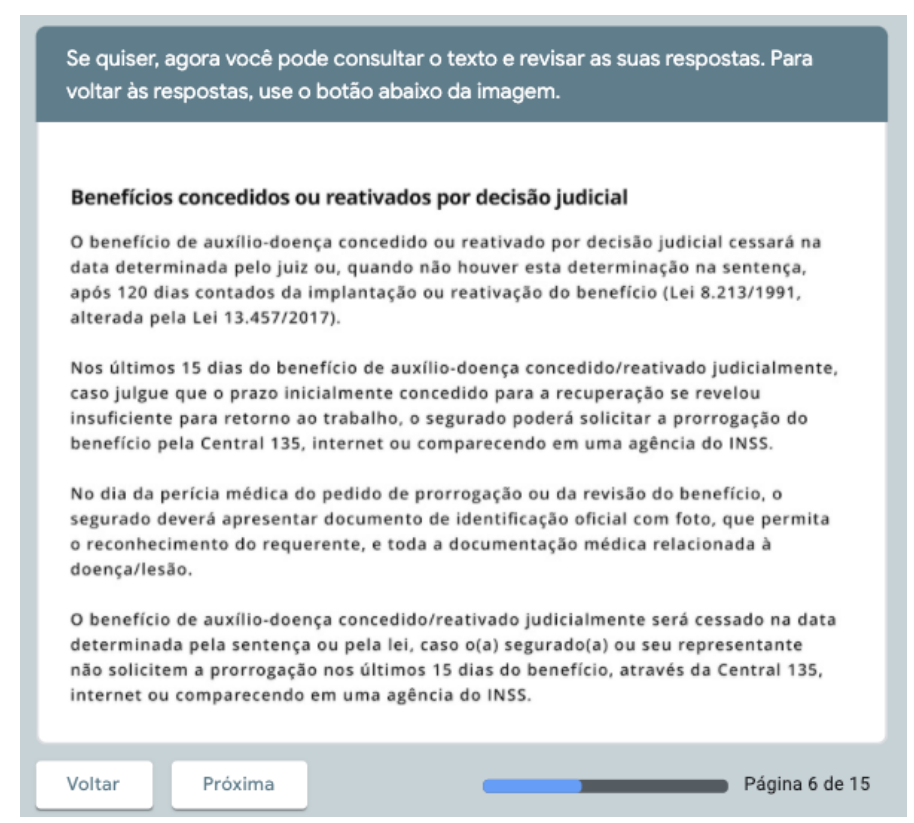

Figura 11: Reprodução da tela do estudo experimental que informava a possibilidade de reler o texto e revisar as respostas

Findo o teste de compreensão, os participantes respondiam a alguns questionários (conforme a ordem apresentada na seção 7.3.6). No questionário Avaliação do texto sobre o Auxílio-doença, havia uma pergunta de protocolo retrospectivo que era respondida em voz alta: "Na sua opinião, alguma parte do texto poderia ter sido exposta de modo mais claro?”. Além das dúvidas que o texto suscitou, muitos participantes relataram problemas na interação com órgãos públicos ao longo da vida.

No questionário Avaliação de experiência recente de uso de serviços públicos digitais, havia uma pergunta de campo aberto: o participante devia digitar dois adjetivos qualificando uma experiência recente de acesso a serviços. Houve quem respondesse com substantivos ou frases completas - isso pode ter ocorrido mais por fadiga de fim de formulário do que por desconhecimento da classe gramatical, dada a alta escolaridade da amostra. Aos que não indicavam adjetivos, a pesquisadora fazia sugestões a partir do conteúdo digitado. Ainda assim, houve quem preferisse deixar como estava, exigindo um trabalho de edição a posteriori. O Apêndice 4 apresenta a lista de adjetivos atribuídos à experiência de usar serviços públicos na internet (originais e editados) 
$\mathrm{Na}$ última tela, junto ao botão para envio do formulário respondido havia a mensagem: "Fim da atividade. Obrigada por contribuir com a produção científica brasileira. O presente trabalho foi realizado com apoio da Coordenação de Aperfeiçoamento de Pessoal de Nível Superior - Brasil (CAPES) - Código de Financiamento 001 (pesquisadora responsável); $\quad \mathrm{CNPq}$ 308375/2017-3 (orientadora); CNPq 311422/2019-5 (coorientadora)."

É importante registrar um problema ocorrido durante a atividade experimental. Após os primeiros quatorze sujeitos do grupo Texto Burocratês terem participado do experimento, ou seja, $2 / 3$ do número necessário ao grupo, a pesquisadora percebeu haver uma palavra errada no título do texto. Em vez de "Benefícios concedidos e reativados por decisão judicial" (título original no site do INSS), havia sido digitado "Benefícios concedidos e reajustados por decisão judicial". Segundo a literatura de Linguística, títulos podem ativar conhecimentos prévios do leitor sobre o tema do texto, atuando como fator top-down no processamento da leitura. Além disso, muitas vezes sumarizam o conteúdo global do que será expresso, influenciando, portanto, na leitura do material que os segue. (VAN DIJK, 1992; KLEIMAN, 1989)

Ou seja, havia o risco de a compreensão do Texto Burocratês ter sido prejudicada pela palavra errada no título. Por isso, todos os quatorze sujeitos foram descartados, zerando o grupo e exigindo novo recrutamento. Vale destacar que um dos primeiros participantes recrutados após o descarte e a correção fez um comentário espontâneo sobre o termo reativado. Ele disse que as palavras "reativado" e "reativação" haviam ficado em sua mente durante toda a leitura do texto. Esse feedback confirmou a importância do descarte, que foi doloroso.

\subsection{3}

\section{Análise e organização de dados}

Usou-se o software de edição de vídeo chamado Filmora para decupar as 42 videochamadas gravadas e aferir as métricas. Como o formulário no Google Forms não possibilitava integrar um cronômetro, todas as métricas temporais foram aferidas manualmente na decupagem. Os tempos foram medidos na unidade "segundos".

Foram aferidas as variáveis dependentes do experimento: 
- Número de acertos no teste de compreensão após a primeira leitura do texto: Esse número foi recuperado assistindo às gravações em vídeo, pois, por default, o formulário Google só registra as respostas finais dos participantes. Modificações feitas após reler o texto são gravadas por cima, apagando as primeiras respostas.

- Número de releituras do texto para conferir elou modificar as respostas do teste de compreensão.

- Tempo total para analisar e responder o teste de compreensão: Essa métrica considerou o tempo começando após a pesquisadora ter dado as instruções em voz alta e terminando quando participante saía da tela do teste.

Também foram registrados os seguintes dados:

- Tempos de leitura em voz alta do texto de uniformização e dos textos sobre o Auxílio-doença (Burocratês ou Simplificado).

- Conferências e modificações feitas nas respostas do teste de compreensão.

- Transcrição das respostas dadas em voz alta à pergunta "Na sua opinião, alguma parte do texto poderia ter sido exposta de modo mais claro?", no questionário Avaliação do texto sobre o Auxílio-doença (seção 7.3.6.). A transcrição e a categorização das respostas estão no Apêndice 4.

Os dados dos participantes originariamente armazenados no Google Forms foram exportados em Excel. As variáveis e os registros aferidos na decupagem das videochamadas foram acrescentadas a essas planilhas Excel.

Foram organizados os dados do campo aberto "Cite dois adjetivos que qualificam esta experiência", no questionário para avaliar experiência com textos e sites governamentais (seção 7.3.6.). Todos os adjetivos que não estavam no feminino tiveram o gênero ajustado. Foi necessário derivar adjetivos das respostas originalmente escritas na forma de substantivos ou frases completas. As respostas originais e os adjetivos finais estão no Apêndice 5. 


\section{5.}

\section{Resultados}

Esta seção apresentará os seguintes resultados:

\section{Quantitativos:}

- Métricas de leitura em voz alta;

- As três variáveis dependentes do teste de compreensão: Número de acertos após a primeira leitura, Número de releituras para ajustar ou conferir respostas e Tempo para completar o teste;

- Questionário Eventual pedido do Auxílio-doença para si

- Questionário Avaliação de textos governamentais na internet

\section{Qualitativos:}

- Questionário Avaliação de experiência recente de uso de serviços públicos digitais

\section{- Quantitativos e qualitativos:}

- Questionário Avaliação do texto sobre o Auxílio-doença

Serão apresentadas as estatísticas descritivas de todos os dados quantitativos e a estatística inferencial das 3 variáveis dependentes do teste de compreensão. $\mathrm{O}$ projeto do experimento foi entre sujeitos: cada uma das condições experimentais (Texto de Burocratês e Texto Simplificado) foi apresentada a um grupo distinto de participantes.

Os dados não-paramétricos - número de acertos após a primeira leitura e número de releituras para ajustar ou conferir respostas - foram submetidos ao teste Mann-Whitney. A análise do resultado da variável tempo para completar o teste era um dado paramétrico e por isso foi submetido ao teste-t Student (COOLICAN, 2014; GREENE; D’OLIVEIRA, 2005).

\subsection{1}

Métricas de leitura em voz alta 
Texto de uniformização - Comparando-se os dois grupos, verificou-se que são grupos homogêneos quanto à velocidade de leitura em voz alta, com o mesmo tempo médio de 38 segundos. Pouca diferença de tempo máximo, tempo mínimo e desvio padrão entre os grupos. A Tabela 6 apresenta os resultados completos.

\begin{tabular}{lcc}
\hline Texto de uniformização & Burocratês & Simplificado \\
\hline Média & 38 & 38 \\
Valor máximo & 49 & 48 \\
Valor mínimo & 31 & 29 \\
Desvio padrão & 4,2814 & 3,9698 \\
\hline
\end{tabular}

Tabela 6: Tempo de leitura (em segundos) em voz alta do texto que foi usado como medida de uniformização do estudo experimental (grupos Burocratês e Simplificado)

Textos sobre o Auxílio-doença - Como foi dito anteriormente, os textos tinham tamanhos diferentes, ou seja, o Texto Burocratês era 19,5\% maior. A média de caracteres lidos por segundo foi praticamente igual (12,5 no Burocratês e 12,4 no Simplificado), confirmando a homogeneidade de leitura em voz alta dos grupos. Não foram observadas diferenças no padrão de pausas e retomadas de sentenças entre os grupos. As Tabelas 7 e 8 apresentam os dados completos.

\begin{tabular}{lcc}
\hline Tempo de leitura em voz alta (segundos) & Burocratês & Simplificado \\
\hline Média & 99 & 79,3 \\
Valor máximo & 129 & 90 \\
Valor mínimo & 68 & 65 \\
Desvio padrão & 14,1403 & 6,1267 \\
\hline
\end{tabular}

Tabela 7: Tempo de leitura em voz alta (segundos) dos textos sobre o Auxílio-doença (grupos Burocratês e Simplificado)

\begin{tabular}{lcc}
\hline Número de caracteres lidos por segundo & Burocratês & Simplificado \\
\hline Média & 12,5 & 12,4 \\
Valor máximo & 17,8 & 15 \\
Valor mínimo & 9,4 & 10,8 \\
Desvio padrão & 1,8543 & 1,0031 \\
\hline
\end{tabular}

Tabela 8: Número de caracteres lidos por segundo dos textos sobre o Auxílio-doença (grupos Burocratês e Simplificado) 


\subsection{2.}

Teste de compreensão: Número de acertos após a primeira leitura (variável dependente 1)

HIPÓTESE DE TRABALHO - A aplicação de parâmetros de Linguagem Simples à escrita de textos de e-gov reduz custos de processamento associados à leitura desses textos, aumentando sua compreensibilidade.

PREVISÃO 1 - O texto em Linguagem Simples deverá gerar, em média, mais acertos no questionário do que a média de acertos do texto em burocratês.

RESULTADOS - Participantes que leram o Texto Burocratês apenas uma vez acertaram menos (Média=9.0; Desvio Padrão= 1.5) do que participantes que leram o Texto Simplificado apenas uma vez (Média=10.5, Desvio Padrão=1.0). A diferença entre as médias foi significativa, $\mathrm{p}<.001$, unicaudal.

Esses resultados serão discutidos na seção 7.6. ("Discussão dos resultados de estudo experimental"). As tabelas com scores individuais de cada grupo estão no Apêndice 6.

A Tabela 9 mostra os resultados do número de acertos e a Figura 12 apresenta o boxplot desses resultados. A Tabela 10 traz o resultado do teste Mann-Whitney.

\begin{tabular}{lcc}
\hline & \multicolumn{2}{c}{ Número de acertos após a primeira leitura } \\
\cline { 2 - 4 } & Burocratês & \multicolumn{2}{c}{ Simplificado } \\
\hline$N^{\circ}$ de sujeitos & 21 & 21 \\
Média & 9.0 & 10.5 \\
Mediana & 9.0 & 10.0 \\
Desvio padrão & 1.5 & 1.0 \\
Valor mínimo & 6.0 & 8.0 \\
Valor máximo & 11.0 & 12.0 \\
& & \\
\hline
\end{tabular}

Tabela 9: Número de acertos no teste de compreensão após a primeira leitura (Burocratês e Simplificado) 


\section{Número de acertos após a primeira leitura}
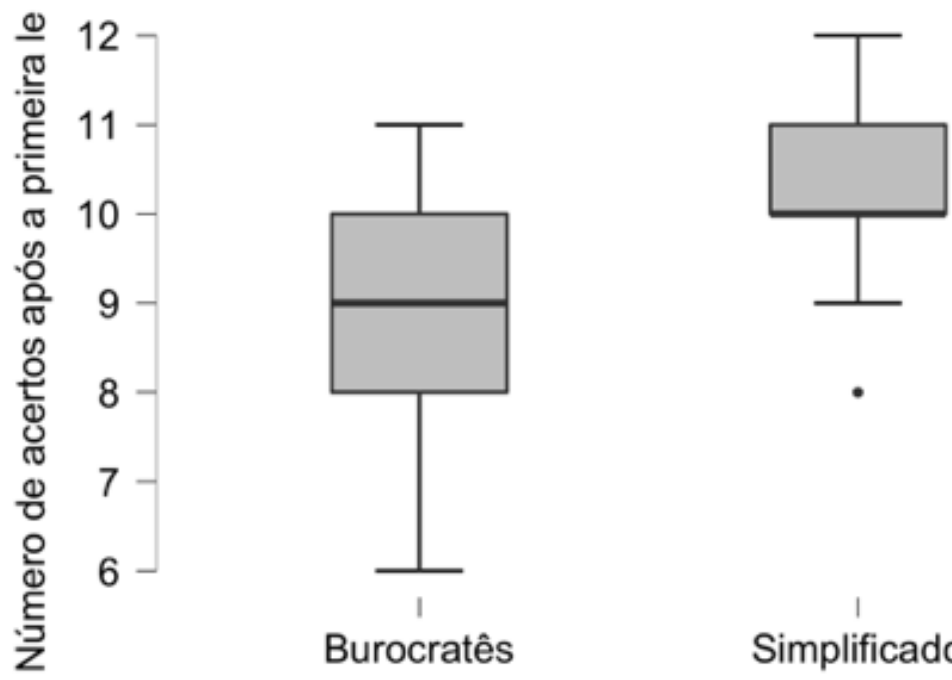

\section{Simplificado}

\section{Tipo de texto}

Figura 12: Boxplot do número de acertos no teste de compreensão após a primeira leitura (Burocratês e Simplificado)

Independent Samples T-Test

\begin{tabular}{lccc}
\hline Número de acertos após a primeira leitura & W & df & p \\
\hline & 95.0 & $<.001$
\end{tabular}

Note. For all tests, the alternative hypothesis specifies that group Burocratês is less than group Simplificado

Note. Mann-Whitney U test.

Tabela 10: Resultado do teste-t Mann-Whitney para a variável dependente Número de acertos após a primeira leitura 


\subsection{3.}

Teste de compreensão: Número de releituras para ajustar ou conferir respostas (variável dependente 2)

HIPÓTESE DE TRABALHO - A aplicação de parâmetros de Linguagem Simples à escrita de textos de e-gov reduz custos de processamento associados à leitura desses textos, aumentando sua compreensibilidade.

PREVISÃO 2 - O texto em Linguagem Simples demandará, em média, um número de releituras para conferir ou modificar respostas menor do que o texto em burocratês.

RESULTADOS - O número de releituras do Texto Burocratês para ajustar ou conferir respostas foi maior (Média=1.3, Desvio Padrão=1.3) do que o número de acertos após a primeira leitura do Texto Simplificado (Média=0.5; Desvio Padrão=0.8). A diferença entre as médias foi significativa, $p=0.015$, unicaudal.

Esses resultados serão discutidos na seção 7.6. ("Discussão dos resultados de estudo experimental"). As tabelas com scores individuais de cada grupo estão no Apêndice 6.

A Tabela 11 mostra os resultados do número de releituras. A Figura 13 apresenta o boxplot dos resultados. A Tabela 12 traz o resultado do teste-t MannWhitney.

\begin{tabular}{lcc}
\hline & \multicolumn{2}{c}{ Número de releituras para ajustar/conferir respostas } \\
\cline { 2 - 4 } & Burocratês & \multicolumn{2}{c}{ Simplificado } \\
\hline$N^{0}$ de sujeitos & 21 & 21 \\
Média & 1.3 & 0.5 \\
Mediana & 1.0 & 0.0 \\
Desvio padrão & 1.3 & 0.8 \\
Valor mínimo & 0.0 & 0.0 \\
Valor máximo & 5.0 & 3.0 \\
& & \\
\hline
\end{tabular}

Tabela 11: Número de releituras para ajustar ou conferir respostas no teste de compreensão (Burocratês e Simplificado) 


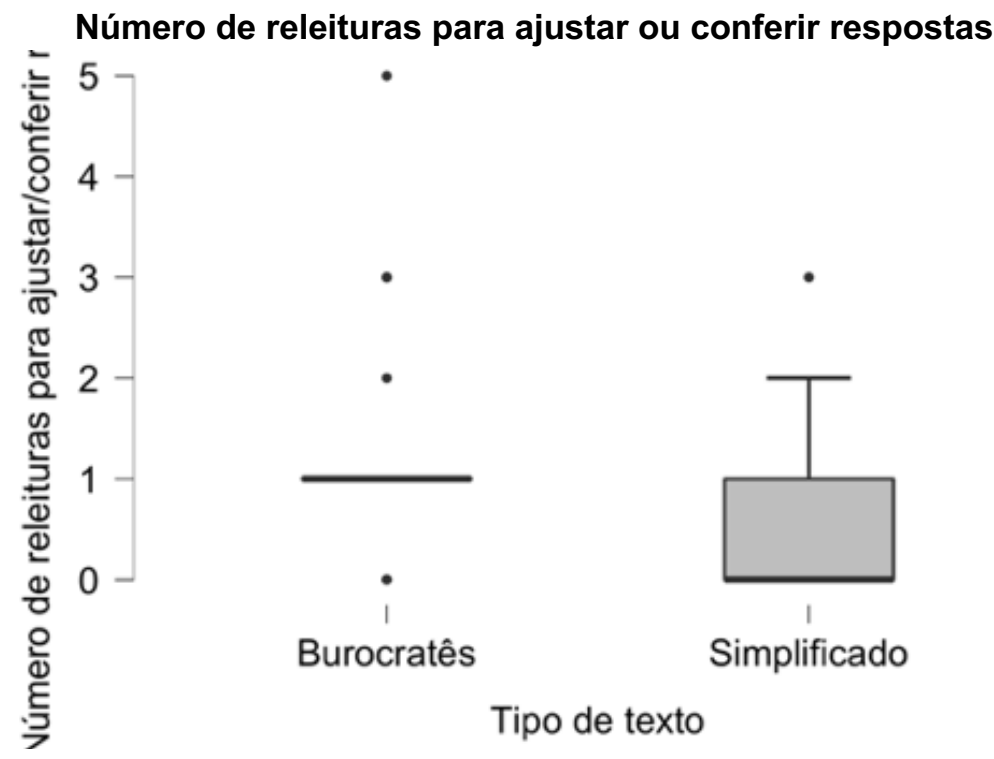

Figura 13: Boxplot do número de releituras para ajustar ou conferir respostas no teste de compreensão (Burocratês e Simplificado)

\section{Independent Samples T-Test}

\begin{tabular}{lccc}
\hline & W & df & p \\
\hline Número de retornos para conferir/ajustar respostas & 310.5 & 0.015
\end{tabular}

Note. Mann-Whitney U test.

Tabela 12: Resultado do teste Mann-Whitney para a variável dependente Número de releituras para conferir ou modificar respostas (Burocratês e Simplificado) 


\subsection{4.}

\section{Teste de compreensão: tempo para completar o teste}

\section{(variável dependente 3 )}

HIPÓTESE DE TRABALHO - A aplicação de parâmetros de Linguagem Simples à escrita de textos de e-gov reduz custos de processamento associados à leitura desses textos, aumentando sua compreensibilidade.

PREVISÃO 3 - Perguntas sobre um texto em Linguagem Simples serão respondidas, na média, em menos tempo do que perguntas sobre um texto em burocratês.

RESULTADO - Participantes que fizeram o teste de compreensão sobre o Texto Burocratês levaram mais tempo para completar o teste de compreensão (Média= 223.0, Desvio Padrão= 74.4) do que os participantes que fizeram o teste sobre o Texto Simplificado (Média= 184.5; Desvio Padrão=61.9). A diferença entre as médias foi significativa, $\mathrm{t}(40)=1.87, \mathrm{p}=0.038$, unicaudal.

Esses resultados serão discutidos na seção 7.6. ("Discussão dos resultados de estudo experimental"). As tabelas com scores individuais de cada grupo estão no Apêndice 6.

A Tabela 13 mostra os resultados do tempo (em segundos) para completar o teste. A Figura 14 apresenta o boxplot. A Tabela 14 traz o resultado do teste-t Student.

\begin{tabular}{lrr}
\hline & \multicolumn{2}{c}{ Tempo para completar o teste (em segundos) } \\
\cline { 2 - 4 } & Burocratês & Simplificado \\
\hline No de sujeitos & 21 & 21 \\
Média & 223.0 & 184.5 \\
Mediana & 218.0 & 176.0 \\
Desvio padrão & 74.4 & 61.9 \\
Valor mínimo & 110.0 & 81.0 \\
Valor máximo & 414.0 & 301.0 \\
& & \\
\hline
\end{tabular}

Tabela 13: Tempo em segundos para completar o teste de compreensão (Burocratês e Simplificado) 


\section{Tempo para completar o teste de compreensão (em segundos)}
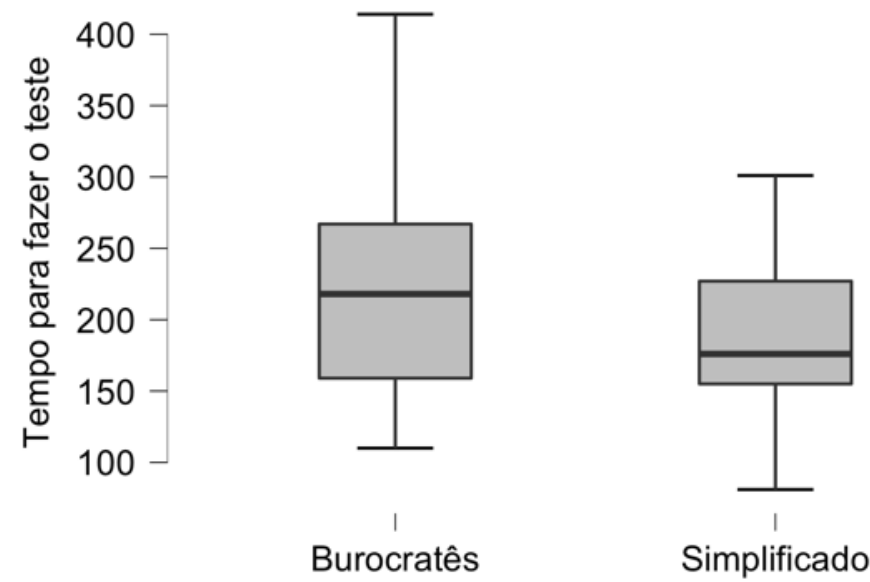

Tipo de texto

Figura 14: Boxplot do tempo em segundos para completar o teste de compreensão (Burocratês e Simplificado)

Student's T-Test

\begin{tabular}{llll}
\hline & $\mathbf{t}$ & $\mathbf{d f}$ & $\mathbf{p}$ \\
\hline Tempo para fazer o teste & 1.827 & 40 & 0.038 \\
\hline
\end{tabular}

Note. For all tests, the alternative hypothesis specifies that group Burocratês is greater than group Simplificado.

Note. Student t-test

Tabela 14: Resultado do teste-t Student para a variável dependente Tempo para completar o teste de compreensão (Burocratês e Simplificado)

\subsection{5.}

\section{Questionário: Avaliação do texto sobre o Auxílio-doença}

O grupo Simplificado demonstrou maior propensão a conversar com base nas informações do texto que havia acabado de ler do que o grupo Burocratês. Quanto à nota atribuída à dificuldade de compreensão do texto, a mediana do grupo Burocratês foi maior do que a mediana do grupo Simplificado. Os grupos tiveram as mesmas impressões sobre a confiança no texto. A Tabela 15 traz os dados completos. Os resultados serão discutidos na seção 7.6. ("Discussão dos resultados de estudo experimental"). 


\begin{tabular}{lcc}
\hline Avaliação do texto sobre o Auxílio-doença & Burocratês & Simplificado \\
\hline & & \\
O que faria se fosse conversar com o & & \\
amigo agora? & $52 \%$ & $67 \%$ \\
Conversaria com base nas informações que li & $48 \%$ & $33 \%$ \\
Buscaria mais informações & & \\
& & \\
Nota atribuída às informações do texto, & & 5 \\
considerando a dificuldade de compreensão & 6 & 9 \\
(0=Fácil de entender; 10=Difícil de entender) & 5,5 & 0 \\
Mediana & 10 & \\
IIQ & 0 & \\
Valor máximo & & \\
Valor mínimo & & \\
& & \\
Após a primeira leitura, você sentiu & & \\
confiança em ter recebido as informações & $52 \%$ & \\
necessárias? & $48 \%$ & \\
Sim & & \\
Não & & \\
\hline
\end{tabular}

Tabela 15: Métricas do questionário para avaliar o texto sobre Auxílio-doença que o participante leu (grupos Burocratês e Simplificado)

Após responderem ao questionário acima, os participantes foram solicitados a indicar em voz alta os aspectos do texto sobre o Auxílio-doença que poderiam ter sido expostos de forma mais clara. Era uma resposta aberta: os participantes podiam indicar quantos aspectos quisessem. A Figura 15 reproduz essa tela do teste.

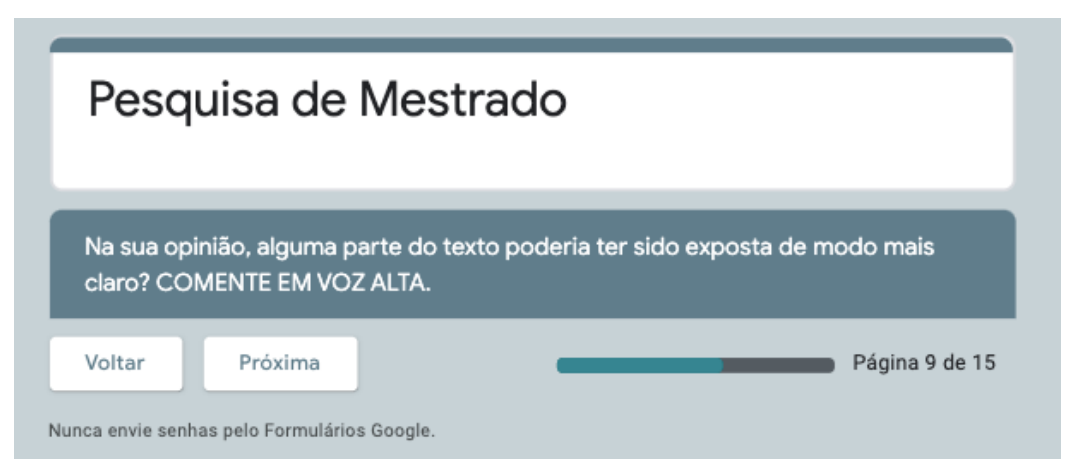

Figura 15: Tela do questionário Avaliação do texto sobre o Auxílio-doença: os participantes deviam responder em voz alta os aspectos pouco claros do texto

Todas as queixas de falta de clareza foram transcritas e categorizadas de acordo com o aspecto apontado: Conteúdo informacional, Formulação de frases, Escolha de palavras, Repetição de informações, Diagramação, Organização e 
Exigência de memória. Na categoria Conteúdo informacional, registrou-se o parágrafo onde ficava a informação pouco clara e o respectivo tema.

A categoria Sem queixas aplicou-se aos participantes que disseram não ter queixas. Assim responderam três participantes do grupo Simplificado e dois do grupo Burocratês. Mas só um do grupo Simplificado efetivamente não se queixou, todos os demais acabaram por indicar alguma queixa.

O número de queixas por participante variou de zero a seis. O número total de queixas do grupo Burocratês foi maior (62) do que o número de queixas do grupo Simplificado (42). As principais queixas foram sobre o conteúdo informacional, sendo mais recorrentes no grupo Burocratês (36) do que no Simplificado (26)

A Tabela 16 mostra os resultados gerais das queixas de falta de clareza.

\begin{tabular}{lcc}
\hline Aspectos que poderiam ter sido mais claros no texto & $\begin{array}{c}\mathbf{N}^{0} \text { de queixas } \\
\text { Burocratês }\end{array}$ & $\begin{array}{c}\mathbf{N}^{\circ} \text { de queixas } \\
\text { Simplificado }\end{array}$ \\
\hline & & 26 \\
Conteúdo informacional & 36 & 0 \\
Repetição de informações & 4 & 0 \\
Escolha de palavras & 3 & 5 \\
Formulação das frases & 6 & 5 \\
Diagramação & 5 & 3 \\
Organização & 4 & 0 \\
Sobrecarga de informação (exige memória) & 2 & 3 \\
Nenhuma dificuldade (achou tudo claro) & 2 & 42 \\
\hline
\end{tabular}

Tabela 16: Queixas de falta de clareza nos textos Burocratês e Simplificado

CONTEÚDO INFORMACIONAL - A variação no prazo do Auxíliodoença foi a informação que gerou mais reclamação em ambos os grupos, sendo mais apontada no Burocratês (11) do que no Simplificado (8).

O prazo da prorrogação do benefício, o papel do representante e as leis geraram mais queixas no grupo Burocratês do que no Simplificado. Houve queixas só feitas pelo grupo Burocratês. Foi o caso da Central 135, a documentação e o excesso de números no texto. Já a informação sobre perícia médica gerou mais dúvidas no grupo Simplificado do que no Burocratês.

O Apêndice 4 traz a transcrição e categorização de todas as queixas.

A Tabela 17 mostra os resultados gerais das queixas de conteúdo informacional. 


\begin{tabular}{lcc}
\hline & Texto Burocratês & Texto Simplificado \\
\hline Parágrafo 1 (prazos do benefício) & 11 & 8 \\
Parágrafo 1 (leis) & 2 & 1 \\
Parágrafo 1 (muitos números) & 1 & 0 \\
Parágrafo 2 (prazo de prorrogação) & 7 & 5 \\
Parágrafo 2 (Central 135) & 0 & 0 \\
Parágrafo 2 (internet) & 0 & 1 \\
Parágrafo 3 (perícia) & 2 & 6 \\
Parágrafo 3 (foto) & 2 & 2 \\
Parágrafo 3 (documentação) & 1 & 0 \\
Parágrafo 4 (representante) & 8 & 3 \\
Parágrafo 4 (prazos do benefício) & 1 & - \\
Paragrato 4 (em caso de dúvıda) & 1 & -
\end{tabular}

* No texto Simplificado, a informação sobre o representante está no parágrafo 2

Tabela 17: Queixas sobre conteúdo informacional dos textos Burocratês e Simplificado

\subsection{6.}

\section{Questionário: Eventual pedido de Auxílio-doença para si}

O grupo Burocratês demonstrou maior propensão a pedir o benefício pela internet do que o grupo Simplificado. O grupo Simplificado mostrou maior tendência a mobilizar alguém de confiança antes de fazer o pedido. Quanto a solicitar pelo telefone, ambos os grupos demonstraram tendência a evitar. Os dois grupos demonstraram maior propensão a lidar sozinhos com o pedido do que contratar um advogado ou despachante. A Tabela 18 apresenta os dados completos. Os resultados serão discutidos na seção 7.6. ("Discussão dos resultados de estudo experimental"). 


\begin{tabular}{|c|c|c|}
\hline Como pediria o Auxílio-doença para si & Burocratês & Simplificado \\
\hline $\begin{array}{l}\text { Eu faria o pedido pelo site ou pelo aplic } \\
\text { do INSS, pois as informações lá dispon } \\
\text { são suficientes } \\
\text { (1=Discordo totalmente; } 7=\text { Concordo totalmente) }\end{array}$ & & \\
\hline $\begin{array}{l}\text { IIQ } \\
\text { Mediana } \\
\text { Valor mínimo } \\
\text { Valor máximo } \\
\text { Amplitude }\end{array}$ & $\begin{array}{l}3,5 \\
6 \\
2 \\
7 \\
5\end{array}$ & $\begin{array}{l}2,5 \\
5 \\
3 \\
7 \\
4\end{array}$ \\
\hline $\begin{array}{l}\text { Eu pediria a alguém de minha confiançe } \\
\text { ler as informações no site do INSS e } \\
\text { conversaria com ela antes de pedir. } \\
\text { ( } 1=\text { Discordo totalmente; } 7=\text { Concordo totalmente) }\end{array}$ & & \\
\hline $\begin{array}{l}\text { IIQ } \\
\text { Mediana } \\
\text { Valor mínimo } \\
\text { Valor máximo } \\
\text { Amplitude }\end{array}$ & $\begin{array}{l}5 \\
4 \\
1 \\
7 \\
6\end{array}$ & $\begin{array}{l}5 \\
5 \\
1 \\
7 \\
6\end{array}$ \\
\hline \multicolumn{3}{|c|}{$\begin{array}{l}\text { Eu faria o pedido pela central telefônica do } \\
\text { INSS, pois só um funcionário do próprio órgão } \\
\text { pode prestar todos os esclarecimentos. } \\
\text { (1=Discordo totalmente; } 7=\text { Concordo totalmente) }\end{array}$} \\
\hline $\begin{array}{l}\text { IIQ } \\
\text { Mediana } \\
\text { Valor mínimo } \\
\text { Valor máximo } \\
\text { Amplitude }\end{array}$ & $\begin{array}{l}5 \\
3 \\
1 \\
7 \\
6\end{array}$ & $\begin{array}{l}4 \\
2 \\
1 \\
7 \\
6\end{array}$ \\
\hline \multicolumn{3}{|c|}{$\begin{array}{l}\text { Eu contrataria um advogado ou despachante } \\
\text { para cuidar do meu pedido de Auxílio-doença, } \\
\text { pois prefiro não lidar com a burocracia. } \\
\text { (1=Discordo totalmente; } 7=\text { Concordo totalmente) }\end{array}$} \\
\hline $\begin{array}{l}\text { IIQ } \\
\text { Mediana } \\
\text { Valor mínimo } \\
\text { Valor máximo } \\
\text { Amplitude }\end{array}$ & $\begin{array}{c}1,5 \\
1 \\
1 \\
7 \\
6\end{array}$ & $\begin{array}{l}2,5 \\
2 \\
1 \\
7 \\
6\end{array}$ \\
\hline
\end{tabular}

Tabela 18: Métricas do questionário sobre um eventual pedido de Auxílio-doença do participante (grupos Burocratês e Simplificado)

\subsection{7.}

\section{Questionário: Avaliação de textos governamentais na internet}

Ambos os grupos tenderam a concordar que a informação governamental na internet é confusa e difícil de entender. Ambos os grupos tenderam a discordar que consultam apenas o site de órgãos públicos quando precisam de informações, preferindo buscar no Google por sites independentes. Ambos os grupos tendem a discordar que os textos governamentais se preocupam em facilitar a vida dos 
usuários. Os dados completos estão na Tabela 19. Os resultados serão discutidos na seção 7.6. ("Discussão dos resultados de estudo experimental”).

\begin{tabular}{lcc}
\hline Avaliação de textos governamentais na internet & Burocratês & Simplificado \\
\hline & & \\
As informações em sites e aplicativos & & \\
governamentais costumam ser confusas e difíceis de & & \\
entender. & & 2,5 \\
(1=Discordo totalmente; $7=$ Concordo totalmente) & 3 & 6 \\
IIQ & 6 & 4 \\
Mediana & 2 & 7 \\
Valor mínimo & 7 & 3 \\
Valor máximo & 5 & \\
Amplitude & & \\
& & \\
Eu percebo nesses textos que existe a preocupação & & 2 \\
em facilitar a vida dos usuários. & & 1 \\
(1=Discordo totalmente; $7=$ Concordo totalmente) & 4 & 4 \\
IIQ & 3 & 3 \\
Mediana & 1 & \\
Valor mínimo & 6 & \\
Valor máximo & 5 &
\end{tabular}

Quando preciso de informação sobre algum serviço governamental, consulto apenas o site do órgão ( $1=$ Discordo totalmente; $7=$ Concordo totalmente)

IIQ

Mediana

Valor mínimo

Valor máximo

Amplitude

$\begin{array}{cc}4,5 & 4 \\ 3 & 3 \\ 1 & 1 \\ 7 & 6 \\ 6 & 5\end{array}$

Vou ao Google para buscar mais informações em sites independentes.

(1=Discordo totalmente; $7=$ Concordo totalmente)

IIQ

Mediana

Valor mínimo

Valor máximo

Amplitude

$\begin{array}{ll}2 & 1 \\ 6 & 7 \\ 1 & 1 \\ 7 & 7 \\ 6 & 6\end{array}$

Tabela 19: Métricas do questionário sobre a experiência dos participantes com textos e sites governamentais (grupos Burocratês e Simplificado)

\subsection{8.}

\section{Questionário: Avaliação de experiência recente de uso de serviços públicos digitais - Nuvens de adjetivos}

Participantes de ambos os grupos foram solicitados a citar dois adjetivos que qualificassem uma experiência recente de acessar serviços públicos em sites 
governamentais. Em cada grupo, uma pessoa deixou a resposta em branco por não ter acessado serviços na internet. Como já foi registrado., houve respostas na forma de frases completas ou substantivos, em vez de adjetivos. Isso exigiu um trabalho de edição da pesquisadora. A lista das respostas originais dos 40 participantes e a lista final de adjetivos está no Apêndice 5.

Assim sendo, foram considerados 80 adjetivos no total. Compuseram-se nuvens de palavras para a visualização dos resultados. O tamanho da palavra na nuvem corresponde ao número de menções recebidas. A cor vermelha indica conotação negativa e a cor azul, positiva.

Resultado geral da avaliação, considerando as respostas de ambos os grupos - Dos 80 adjetivos indicados, 63 tinham conotação negativa (79\%) e 17, conotação positiva (21\%). As qualificações negativas mais recorrentes, considerando ambos os grupos, foram: "confusa" (14 incidências), "estressante" (6 incidências), "amedrontadora" e "informação dispersa" (ambas com 3 incidências). As qualificações positivas mais recorrentes foram "satisfatória", "simples" e "útil" ( 2 incidências cada). A Figura 16 mostra a nuvem com o total de 80 adjetivos que foram mencionados pelos dois grupos.

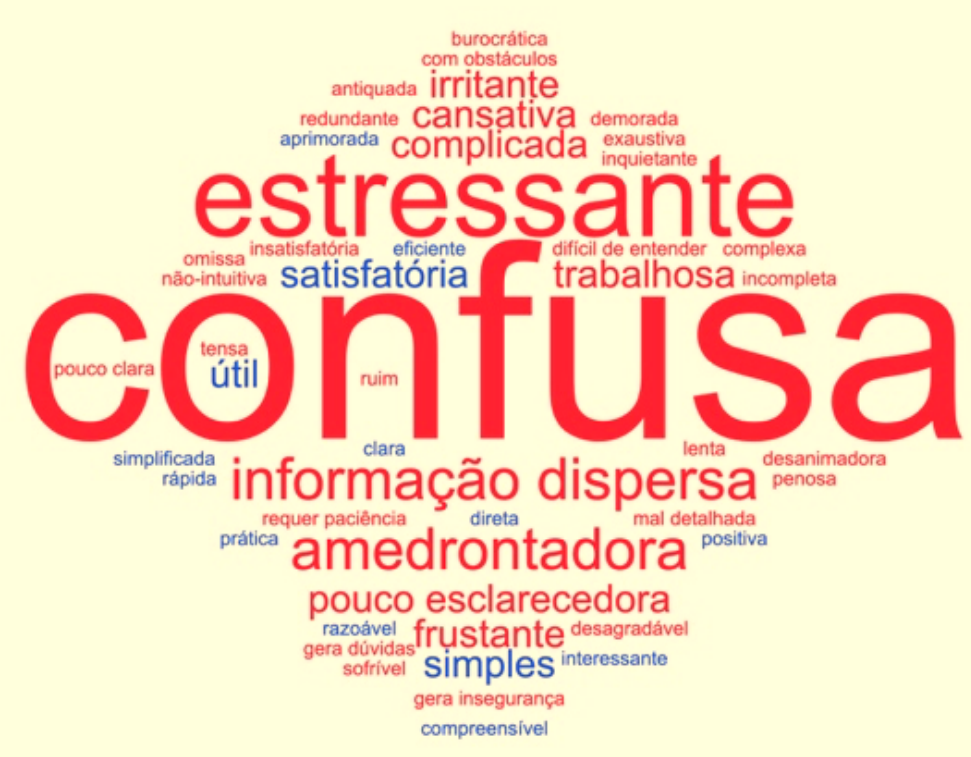

Figura 16: Nuvem de adjetivos citados por participantes de ambos os grupos para qualificar a experiência de usar sites de governo 
Respostas do Grupo Burocratês - A incidência de qualificações negativas (29) representou $72,5 \%$ do total. As qualificações positivas (11) foram $25,5 \%$ do total. As palavras mais mencionadas foram "confusa" (7 incidências), "estressante" (3 incidências) e "amedrontadora" (2 incidências). Em ordem alfabética, os demais adjetivos citados foram: com obstáculos, demorada, desanimadora, direta, eficiente, exaustiva, frustrante, gera dúvidas, gera insegurança, informação dispersa, inquietante, interessante, irritante, lenta, mal detalhada, omissa, positiva, rápida, razoável, redundante, ruim, satisfatória, simples, simplificada, sofrível, trabalhosa e útil. A Figura 17 mostra a nuvem de palavras com todos adjetivos mencionados pelo grupo Burocratês.

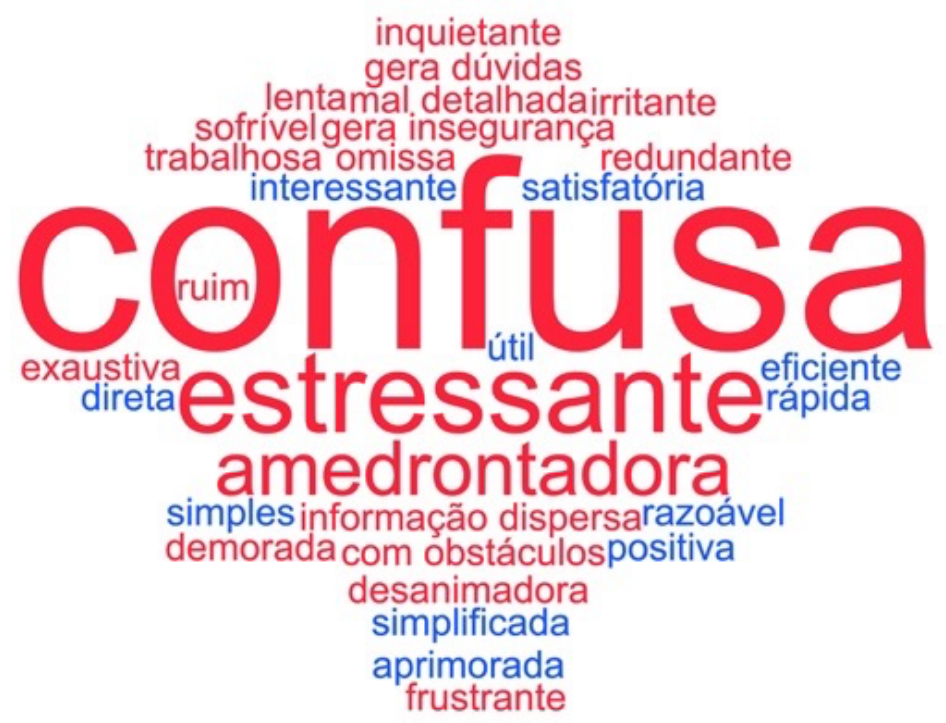

Figura 17: Nuvem de adjetivos citados por participantes do grupo Burocratês para qualificar a experiência de usar sites governamentais

Respostas do Grupo Simplificado - Registrou-se uma incidência maior de qualificações negativas (34), totalizando $85 \%$ das menções. As qualificações positivas (6) representaram $15 \%$ do total. As qualificações mais citadas foram "confusa" (7 incidências); "estressante" (3 incidências); "cansativa", "complicada", "informação dispersa" e "pouco esclarecedora" (2 incidências cada). Em ordem alfabética, os demais adjetivos citados foram: amedrontadora, antiquada, burocrática, clara, complexa, compreensível, desagradável, difícil de entender, frustrante, incompleta, insatisfatória, irritante, não-intuitiva, penosa, pouco clara, 
prática, requer paciência, satisfatória, simples, tensa, trabalhosa e útil A Figura 18 mostra a nuvem de palavras com todos adjetivos mencionados pelo grupo Simplificado

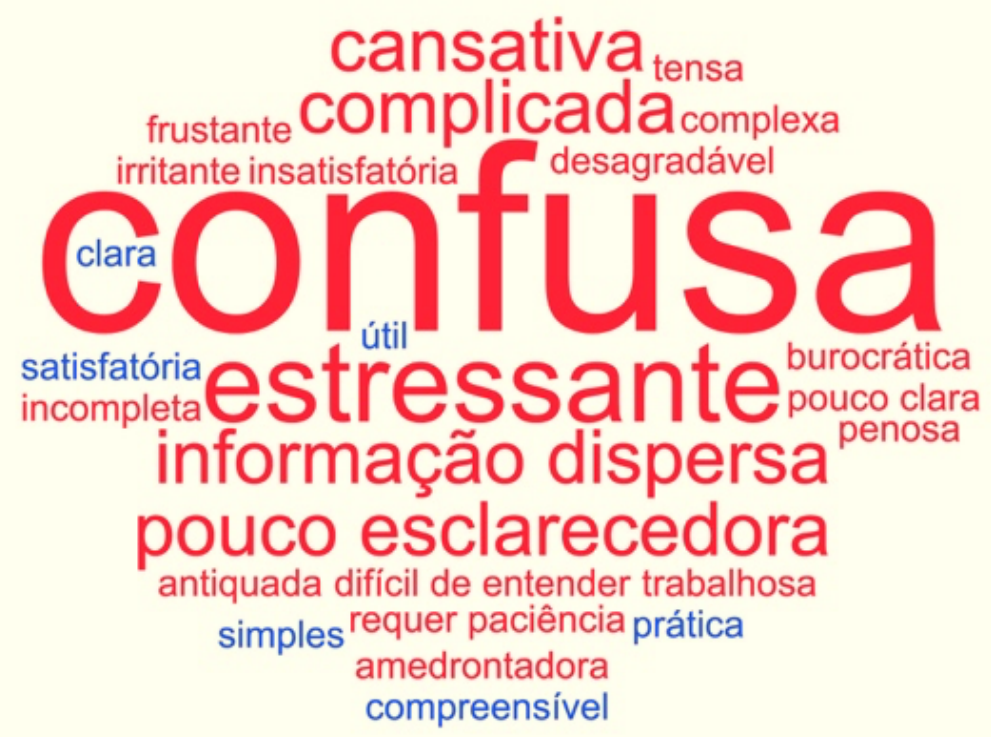

Figura 18: Nuvem de adjetivos citados por participantes do grupo Simplificado, para qualificar a experiência de usar sites governamentais

\section{6}

Discussão dos resultados do estudo experimental

Esta discussão começa com as métricas resultantes do teste de compreensão. A seguir, comenta os dados coletados nos questionários de avaliação. Depois, avalia os resultados alcançados. Por fim, faz um balanço das condições nas quais o estudo experimental se realizou.

\subsection{1.}

\section{Teste de compreensão}

As novas dinâmicas da pandemia demandaram um tempo adicional para cumprir as tarefas do experimento. Elaborar e validar Texto Simplificado e as 12 afirmativas em uma formulação ainda mais simples requeriria dias adicionais. A 
pesquisadora foi conservadora já na primeira versão de ambos materiais. E o processo de validação pelo painel de especialistas reintroduziu elementos linguísticos que haviam sido evitados justamente por dificultarem a compreensão. Os elementos foram mantidos na reescrita final, mesmo não sendo as alternativas simplificadas originalmente propostas, dado que a precisão técnica era um critério de validação. Quanto às 12 afirmativas, a escassez de tempo para aplainar a estrutura linguística e validar com o painel foi ainda mais sentida. Quando foram solicitados a apontar em voz alta os aspectos pouco claros do texto que leram, alguns participantes se queixaram da formulação das perguntas.

Variável dependente 1 - Número de acertos após a primeira leitura: Esta variável obteve resultados muito significativos estatisticamente $(\mathrm{p}<0.001)$. A nota máxima do teste era 12. A média de acertos do grupo Simplificado foi maior (10.5) do que o grupo Burocratês (9.0). A mediana do grupo Simplificado também foi maior (10.0) do que a do grupo Burocratês (9.0). A nota mínima do grupo Simplificado (8) foi superior ao do grupo Burocratês (6). Quatro participantes do grupo Simplificado gabaritaram o teste na primeira leitura, o que não ocorreu com ninguém no grupo Burocratês. Vale observar que compreender documentos na primeira leitura é um dos objetivos que a técnica Linguagem Simples visa alcançar (PLAIN, s/d).

Variável dependente 2 - Número de releituras para ajustar ou conferir: Os resultados indicaram que essa variável teve significância estatística, pois $\mathrm{p}=0.015$. Mostrou que mais de $50 \%$ do grupo Simplificado deu o teste por concluído com apenas uma leitura. Isso só ocorreu com $25 \%$ dos participantes do grupo Burocratês.

Variável dependente 3 - Tempo para completar o teste: Também foi estatisticamente signficativo o contraste entre os textos para esta variável $(\mathrm{p}=$ 0,038). O grupo Simplificado foi, em média, mais rápido (184.5 segundos) do que a média do grupo Burocratês (223.0). Os tempos mínimos e máximos para concluir o teste foram inferiores no grupo Simplificado (81.0 e 301.0) do que no grupo Burocratês (110.0 e 414.0).

O Quadro 15 apresenta os achados do teste de compreensão conforme o tipo de variável, a previsão nas tarefas de compreensão e os resultados. 


\begin{tabular}{|c|c|c|c|}
\hline Variável & $\begin{array}{l}\text { Número de acertos após } \\
\text { ler o texto uma vez }\end{array}$ & $\begin{array}{l}\text { Número de releituras para } \\
\text { ajustar ou conferir respostas }\end{array}$ & $\begin{array}{l}\text { Tempo para completar } \\
\text { o teste }\end{array}$ \\
\hline Previsão & $\begin{array}{l}\text { A média de acertos no } \\
\text { questionário do Texto } \\
\text { Simplificado deverá ser maior } \\
\text { do que a média de acertos do } \\
\text { Texto Burocratês }\end{array}$ & $\begin{array}{l}\text { O Texto Simplificado } \\
\text { demandará, em média, um } \\
\text { número menor de releituras } \\
\text { para conferir ou modificar } \\
\text { respostas do que o } \\
\text { Texto Burocratês. }\end{array}$ & $\begin{array}{l}\text { Perguntas sobre Texto } \\
\text { Simplificado serão } \\
\text { respondidas, na média, mais } \\
\text { rápido do que perguntas } \\
\text { sobre o Texto Burocratês. }\end{array}$ \\
\hline Resultado & $\begin{array}{l}\text { Participantes que leram o } \\
\text { Texto Simplificado só uma vez } \\
\text { acertaram mais do que } \\
\text { participantes que leram o } \\
\text { Texto Burocratês só uma vez. } \\
\text { Média Simplificado = } 10.5 \text {, } \\
\text { Desvio Padrão= } 1.0 . \\
\text { Média Burocratês = } 9.0 \text {; } \\
\text { Desvio Padrão= } 1.5 . \\
\text { Diferença entre médias } \\
\text { significativa, } p<.001 \text {, unicaudal. }\end{array}$ & $\begin{array}{l}\text { O número de releituras do } \\
\text { Texto Simplificado foi menor } \\
\text { do que as releituras do } \\
\text { Texto Burocratês } \\
\text { Média Simplificado }=0.5 ; \\
\text { Desvio Padrão }=0.8 \\
\text { Média Burocratês }=1.3 \\
\text { Desvio Padrão }=1.3 \\
\text { Diferença entre as médias } \\
\text { significativa, } p=0.015, \text { unicaudal. }\end{array}$ & $\begin{array}{l}\text { Participantes que fizeram o } \\
\text { teste de compreensão sobre } \\
\text { o Texto Simplificado foram } \\
\text { mais rápidos para completar } \\
\text { o teste do que os participantes } \\
\text { que fizeram o teste sobre } \\
\text { o Texto Burocratês } \\
\text { Média Simplificado = } 184.5 ; \\
\text { Desvio Padrão }=61.9 \\
\text { Média Burocratês }=223.0 \text {, } \\
\text { Desvio Padrão }=74.4 \\
\text { Diferença entre as médias } \\
\text { significativa, } p=0.038, \text { unicaudal. }\end{array}$ \\
\hline
\end{tabular}

Quadro 15: Achados do teste de compreensão conforme o tipo de variável, a previsão nas tarefas de compreensão e os resultados.

\subsection{2.}

\section{Questionários}

Assim como ocorreu no teste de compreensão, a quantidade de dados coletados no questionário foi superior ao tempo disponível para fazer cruzamentos e inferências. Estudos futuros poderão se ocupar de tais ações.

Avaliação do texto sobre o Auxílio-doença: Mais participantes do grupo Simplificado (67\%) conversariam com o amigo com base nas informações que leram no texto do que participantes do grupo Burocratês (52\%). Esse resultado talvez indique que o texto mais simples foi mais informativo. Com relação à percepção da dificuldade de compreender as informações do texto em uma escala de 1 a 10, sendo 10 o mais difícil de entender, a mediana de leitores do Simplificado foi mais baixa (4) do que a mediana de leitores do texto Burocratês (6).

Os resultados da pergunta "Após a primeira leitura, você sentiu confiança em ter recebido as informações necessárias?" devem ser relativizados ou mesmo desconsiderados, pois a pergunta foi mal posicionada no questionário. Deveria ter sido apresentada logo após o término do teste e antes de aos participantes serem 
informados sobre a possibilidade de releitura para ajustes ou conferências. Entretanto, foi posicionada após o fim das releituras e quando o participante já havia respondido duas perguntas de avaliação. É difícil resgatar as impressões sobre a confiança na leitura inicial quando já se releu o texto e outras informações foram processadas. De todo modo, ambos os grupos responderam em igual proporção: $52 \%$ sentiram confiança e $48 \%$ não sentiram confiança em ter recebido as informações necessárias após a primeira leitura. Uma eventual replicação dessa metodologia deveria apresentar a pergunta na tela imediatamente posterior às respostas dadas na primeira leitura.

O questionário tinha uma pergunta aberta sobre o que poderia ter sido exposto de forma mais clara no texto sobre o Auxílio-doença. Os participantes podiam indicar quantos aspectos quisessem, não havia limite para as queixas. Também não havia uma lista prévia de categorias de falta de clareza, a resposta era espontânea. Dos 42 participantes do teste, só um, que leu o Texto Simplificado, não indicou problemas de falta de clareza no texto. O grupo Burocratês acumulou um número maior de queixas (62) do que o grupo Simplificado (42). O prazo do benefício foi o conteúdo informacional que suscitou mais dúvidas, sendo maior no Burocratês (11) do que no Simplificado (8). O volume de queixas que o Texto Simplificado recebeu sugere que, mesmo com as modificações realizadas, ainda havia fatores que podem ter comprometido a compreensibilidade do texto. Entre esses fatores, é possível que o próprio conteúdo informacional seja em si um elemento dificultador.

A transcrição das respostas dos participantes é muito rica em dados e será analisada em um estudo futuro. A transcrição mostra como a leitura do texto foi exaustiva, com peso maior no grupo Burocratês. Leitores altamente proficientes, especialmente os que leram o texto Burocratês, relataram confusão, sobrecarrega da memória de trabalho e necessidade de mais tempo para processar as informações, ficando com dúvidas mesmo após sucessivas releituras. É válido observar que vários participantes se queixaram de aspectos relativos a diagramação e organização visual da informação. As queixas mais recorrentes foram a falta de recursos visuais que ajudassem a localizar as informações (tais como negrito, caixaalta, palavras-chave em destaque), a falta de tabelas que organizassem as informações apresentadas linearmente e o efeito "massa de texto". Ficou clara a 
importância da hierarquia e da organização da informação, com uso de tópicos em bullet points ${ }^{105}$.

A transcrição e a categorização das respostas constam do Apêndice 4.

Eventual pedido de Auxílio-doença para si: Esse questionário pedia que participantes classificassem um conjunto de afirmativas em uma escala Likert de 1 (discordo totalmente) a 7 (concordo totalmente). O objetivo era aferir uma percepção genérica dos sujeitos quanto a se relacionar com canais de atendimento do INSS. As respostas não tinham vínculo direto com o texto lido no teste - mas a versão lida possivelmente exerceu influência. Ambos os grupos tenderam a discordar que as informações no site ou no aplicativo do INSS são suficientes para dar entrada em um pedido de Auxílio-doença. Em relação à afirmativa "Eu faria o pedido pelo site ou pelo aplicativo do INSS, pois as informações lá são suficientes", o grupo Simplificado discordou mais (mediana 2.5) do que o Burocratês (mediana 3.5). Ambos os grupos demonstraram inclinação a pedir ajuda para alguém de modo a esclarecer dúvidas, mais o grupo Simplificado (mediana 5) do que o Burocratês (mediana 4). Ambos os grupos tendem a discordar que o atendimento telefônico possibilita obter todos os esclarecimentos, tendência maior no grupo Simplificado (mediana 2) do que o grupo Burocratês (mediana 3). A burocracia do INSS parece não intimidar os grupos: a mediana de ambos - Burocratês (1) e Simplificado (2) aponta para a discordância em contratar um advogado ou despachante em um eventual pedido de Auxílio-doença.

Avaliação de textos governamentais na internet: Esse questionário pedia que participantes classificassem um conjunto de afirmativas em uma escala Likert de 1 (discordo totalmente) a 7 (concordo totalmente). As respostas diferiram pouco entre os grupos. As respostas confirmaram a percepção que informações em e-gov são confusas e difíceis de entender (mediana 6 em ambos os grupos), percepção que foi capturada em outras seções do questionário. Os grupos tenderam a discordar que sites de órgãos públicos são sua fonte exclusiva para informação sobre e-serviços (mediana 3 em ambos os grupos). A percepção de que é melhor buscar informações no Google do que informar-se exclusivamente nos sites governamentais tendeu a

105 É importante lembrar que "Listar informações em tópicos" faz parte das 12 diretrizes governamentais de Linguagem Simples mais recorrentes no levantamento documental desta pesquisa (vide capítulo 6, Quadro 9) 
ser alta em ambos os grupos, sendo a mediana do grupo Simplificado maior (7) do que a do grupo Burocratês (6).

Avaliação da experiência de usar serviços públicos digitais: Como já foi detalhado na seção 7.5.8. (“Avaliação de experiência recente de uso de serviços públicos digitais - Nuvens de adjetivos”), a atribuição de adjetivos para qualificar experiências com o uso de e-serviços registrou a insatisfação de ambos os grupos. Houve $79 \%$ de adjetivos com conotação negativa e $21 \%$ com conotação negativa. Os dois adjetivos mais citados para qualificar a experiência de uso de e-serviços foram "confusa" e "estressante". Esses resultados são uma confirmação adicional do que respostas anteriores já indicaram: leitores altamente proficientes têm dificuldade com os elementos linguísticos do burocratês e pouca paciência para destrinchar a informação em emaranhados textuais.

\subsection{3.}

\section{Avaliação geral dos resultados}

Os resultados obtidos no estudo experimental estão em consonância com as colocações feitas sobre o custo de processamento associado à leitura de textos com alta complexidade lexical e sintática (capítulo 2), sobre os elementos do burocratês comprometerem até a compreensão de pessoas altamente escolarizadas (capítulo 3) e sobre a falta de clareza de informações do INSS persistir em plataformas digitais (capítulo 5).

Os resultados também se alinham à hipótese de trabalho do estudo experimental, que previa a redução de custos de processamento mental associados à leitura de textos de e-gov se parâmetros de Linguagem Simples fossem aplicados a esses textos, aumentando a compreensibilidade.

Sujeitos com pós-graduação, habituados a processar informações complexas e intrincadas típicas do gênero textual acadêmico, tiveram dificuldade em compreender as informações de um texto curto sobre o Auxílio-doença. "Representantes do topo da pirâmide educacional brasileira" precisaram reler, em média, 1,3 vezes o Texto Burocratês para responder o teste de compreensão. Houve quem precisasse ler 5 vezes até dar o teste por concluído. 
O Texto Burocratês provocou mais erros no teste de compreensão do que o Texto Simplificado, recebeu avaliações mais desfavoráveis e motivou um número maior de queixas do que o Texto Simplificado, especialmente queixas de conteúdo informacional. O Texto Simplificado também foi alvo de queixas dos participantes e também gerou dúvidas de compreensão. A reescrita em Linguagem Simples gerou melhores resultados do teste de compreensão, entretanto, também recebeu queixas dos participantes quanto à falta de clareza, conforme foi detalhado no tópico "Questionários".

A análise das estatísticas descritivas e os dados qualitativos deste estudo experimental geram subsídios adicionais para contextualizar os dados da pesquisa TIC Domicílios 2019 que foram mencionados no capítulo 5, sobre 55\% dos usuários brasileiros de internet não usarem o autoatendimento online pois acham complicado o contato com o governo pela internet. Neste sentido, deve-se considerar que os adjetivos mais citados pelos participantes do experimento para qualificar a experiência de usar serviços públicos digitais foram "confusa" e “estressante". É certo que a percepção de complicação resulta de vários fatores, sendo o estilo textual apenas um deles. O presente experimento contribuiu com subsídios sobre o papel da linguagem para reafirmar ou amainar a complicação que é percebida pelos cidadãos.

\subsection{4.}

\section{Condições de realização e limitações}

Foi desafiador realizar uma pesquisa de Mestrado com estudo experimental, aplicação de questionários e levantamento documental em meio à pandemia de Covid-19. A pesquisadora se propôs a executar tal escopo por ser incerto prosseguir a investigação em um futuro Doutorado.

O cronograma apertado cobrou seu preço. A adaptação para o formato remoto exigiu mais tempo em todas as etapas do experimento, especialmente recrutar participantes, coletar e tratar os dados. O tempo alocado para elaborar e testar os materiais de um experimento realizado $100 \%$ em home office também se mostrou insuficiente. $\mathrm{O}$ mesmo ocorreu com o tempo alocado à análise de dados: impossibilitou investigar correlações entre conteúdo informacional e estrutura 
linguística no teste de compreensão e aprofundar a análise dos dados coletados nos questionários.

Com relação ao número de participantes, seria oportuno ter tido uma amostragem maior. É importante lembrar que 64 pessoas, realizaram o teste, mas foi necessário descartar 22 participações, conforme foi relatado na seção 7.4.2. (“Atividade experimental”). As 64 videochamadas foram feitas em quinze dias. Era possível agendar horários até às 20h. Alguns participantes de videochamadas noturnas tinham fisionomia cansada, estavam dispersos e o ambiente doméstico era ruidoso. Se por um lado teria sido melhor limitar o agendamento aos turnos da manhã e da tarde, por outro, o experimento aproximou-se das condições reais dos usuários de internet, que costumam ter a atenção fragmentada por demandas concomitantes.

Se o tempo de condução tivesse sido maior, teria sido possível projetar uma distribuição mais homogênea de participantes entre grupos, no que diz respeito a área de formação e nível de escolaridade. O grupo Simplificado recebeu 48\% dos participantes com MBA/Especialização. No grupo Burocratês, eram apenas 10\%. Por um lado, nesse grupo só havia profissionais de Engenharia e Ciências da Terra. Por outro lado, todos os profissionais de Linguística, Letras e Artes caíram no grupo Simplificado. Esta questão específica associada à formação acadêmica e áreas de atuação precisará ser considerada em estudos futuros.

Só na etapa de análise e organização de dados notou-se um aspecto estrutural do formulário do teste de compreensão. O enunciado dizia: "Marque todas as afirmativas que achar corretas". Se um participante marcava, por exemplo, as afirmativas 1A, 2B, 2D, 3C e 3D, só essas cinco respostas eram registradas no Google Forms, pois as consideradas erradas permaneciam em branco e não eram contabilizadas pela ferramenta. Ocorre que o experimento pretendia examinar o conteúdo informacional dos principais erros do teste, tornando obrigatório registrar das afirmativas não-marcadas. Ou seja, o enunciado do teste de compreensão deveria ser sido: "Marque verdadeiro ou falso" e, assim, todos os campos teriam sido registrados. Foi necessário lançar à mão as afirmativas que os participantes consideraram erradas.

O Painel de Especialistas em Direito Previdenciário trabalhou na validação técnica dos materiais do teste de compreensão de forma assíncrona. Isso ocorreu devido à sobrecarga de agendas. Se tivesse sido possível agendar encontros com os 
três advogados simultaneamente, o Texto Simplificado e as afirmativas do teste de compreensão talvez tivessem ficado mais enxutos e mais simples. Foram necessárias várias rodadas de interação por Whatsapp e email para aprovar os materiais, quando um único encontro simultâneo possivelmente fosse mais objetivo e desse melhor resultado. A decupagem das videochamadas também exigiu um tempo maior do que estava previamente antecipado, avançando sobre o cronograma do tratamento e da análise de dados.

O cronograma apertado impossibilitou analisar vários dados, tais como as correlações entre o conteúdo informacional dos textos e a estrutura linguística no teste de compreensão (a relação foi apenas indicada no Apêndice 3); tipos de erro que os participantes cometeram antes e depois das releituras; a relação entre erros e elementos linguísticos; relação entre queixas de falta de clareza e erros cometidos; custo cognitivo associado às estruturas linguísticas de cada bloco temático de afirmativas. A escassez de tempo também impossibilitou gerar inferências tais como "o tema X gerou mais erros". Futuros estudos poderão dar conta de tais análises.

Mesmo considerando as limitações, o teste de compreensão evidenciou a dificuldade no processamento da informação sobre um serviço público que tem engrenagem complexa como o Auxílio-doença, mesmo entre leitores avançados. O burocratês acrescenta dificuldade a um processo que já é bastante complexo e difícil de entender. A organização da informação também desempenha um papel importante nesse contexto, mas estava fora do recorte dessa pesquisa, focada em elementos linguísticos. Este ponto será retomado nas recomendações para futuras pesquisas, no capítulo 8 . 


\section{8.}

\section{Análise geral da pesquisa e conclusões}

Este capítulo começa com uma análise geral da pesquisa. Depois, mostra como o presente estudo está em sintonia com o Zeitgeist (espírito do tempo), no sentido de responder a fatos e tendências que vêm impulsionando o movimento Linguagem Simples no Brasil. Segue elencando alguns frutos da pesquisa, além de sinalizar possíveis desdobramentos e recomendações para estudos futuros. Por fim, integra a fundamentação conceitual da pesquisa às evidências que foram geradas. Mostra como os resultados alcançados podem contribuir para fomentar a aproximação dos campos do Design e da Linguística e para a formulação de políticas públicas.

\section{1.}

\section{Análise geral}

Considera-se respondido o problema que norteou esta pesquisa: "Qual é o impacto do grau de complexidade do estilo de escrita na compreensibilidade textual de serviços públicos digitais?”.

O objetivo geral da pesquisa - "Estimar o papel do estilo de escrita na compreensibilidade de informações sobre serviços públicos digitais" - foi plenamente alcançado. A pesquisa coletou, examinou e sistematizou um número expressivo de referências que contribuem para tal estimativa. A revisão bibliográfica sobre os temas da compreensibilidade textual (capítulo 2), burocratês (capítulo 3), Linguagem Simples (capítulo 4) e governo eletrônico (capítulo 5), forneceram muitos insumos, assim como o levantamento documental de diretrizes governamentais (capítulo 6) e o estudo experimental (capítulo 7).

Todos os objetivos específicos também foram alcançados. 
O estudo experimental foi bem-sucedido ao capturar os efeitos do "ruído cognitivo" que um estilo complexo como o burocratês costuma provocar na interação com governo eletrônico, mesmo em pessoas com alta escolaridade.

Os dados coletados no estudo experimental com 42 adultos pós-graduados confirmaram que a escrita complexa tende a prejudicar o entendimento mesmo de quem consegue lidar com textos que demandam alto custo de processamento mental - caso dos participantes, habituados a ler textos acadêmicos.

A hipótese de trabalho do teste de compreensão previa que "a aplicação de parâmetros de Linguagem Simples à escrita de textos de e-gov reduz custos de processamento associados à leitura desses textos, aumentando a sua compreensibilidade".

As três previsões em tarefa de compreensão foram confirmadas pelo experimento: (i) o texto em Linguagem Simples gerou, em média, mais acertos no questionário do que a média de acertos do texto em burocratês. (ii) o texto em Linguagem Simples demandou, em média, um número de releituras para conferir ou modificar respostas menor do que o texto em burocratês, e (iii) perguntas sobre um texto em Linguagem Simples foram respondidas, na média, mais rápido do que perguntas sobre um texto em burocratês.

Os dados qualitativos coletados no experimento confirmaram a dificuldade de processamento e a sobrecarga na memória de trabalho nas queixas dos participantes sobre falta de clareza no texto do Auxílio-doença (seção 7.5.5.) e na qualificação 79\% negativa da experiência em usar serviços públicos na internet (seção 7.5.8).

O que poderia ter sido diferente - Alguns procedimentos relacionados ao estudo experimental poderiam ter sido mais proveitosos. Cursar uma disciplina de metodologia quantitativa teria contribuído para melhor planejar o cronograma do experimento e para o embasamento estatístico da pesquisadora, que realizou um estudo autônomo.

Quanto aos materiais do teste de compreensão, o Texto Simplificado e as afirmativas do teste poderiam ter sido mais enxutos e mais simples. Quanto ao painel de especialistas em Direito Previdenciário, teria sido melhor discutir os ajustes conjuntamente, e não individualmente, possibilitando pactuar mais rápido a redação final e garantir a máxima simplificação. 
Quanto aos questionários de avaliação, houve um equívoco no posicionamento da pergunta sobre confiança em ter recebido as informações necessárias na primeira leitura do texto. Isso prejudicou a captura do sentimento do participante. Percepção de confiança é um tema fundamental da contemporaneidade, especialmente quando vinculado ao poder público.

Quanto às queixas em voz alta sobre a falta de clareza no texto do INSS, teria sido importante fazer a análise de conteúdo da transcrição, que foi apenas categorizada (Apêndice 4). Os comentários sobre falta de clareza e dificuldade de processamento mental da informação ali expostos se mostraram muito ricos. Confrontam a crítica de que leitores proficientes "dão conta" ou até preferem textos com alta densidade informacional e estrutura sintática complexa para não perderem nada da informação apresentada, conforme foi discutido na seção 4.4. (“Críticas ao movimento e à técnica). A exploração desse material transcrito permitirá desenvolver estudos futuros.

Efeitos da pandemia na realização da pesquisa - Quem fez pesquisa acadêmica no período 2019-2021 vivenciou contextos opostos. Em 2019, a rotina incluía aulas presenciais, debates e trocas com os colegas, reuniões e eventos da linha de pesquisa, visitas ilimitadas a bibliotecas, produção e submissão de artigos, viagens para participar de congressos.

Naquele momento pré-pandêmico, a recepção da comunidade científica à primeira etapa da presente pesquisa foi bastante positiva. Quatro trabalhos foram submetidos, aceitos e apresentados in loco nos seguintes congressos:

- $9^{o}$ Congresso Internacional de Design da Informação-CIDI, em 13/11/2019, em Belo Horizonte (FISCHER ET AL., 2019);

- 10th International Conference, Senses \& Sensibility: Lost in (G)localization, em 27/11/2019, em Lisboa (FISCHER; MONT'ALVÃO; RODRIGUES, 2019b);

- $17^{\circ}$ Congresso Internacional de Ergonomia e Usabilidade de Interfaces e Interação Humano-Computador, em 11/12/2019, no Rio de Janeiro (FISCHER; MONT'ALVÃO; RODRIGUES, 2019c); 
- X Jornada de Pesquisa e Extensão do Centro de Formação da Câmara dos Deputados, em 16/09/2019, em Brasília (FISCHER; MONT'ALVÃO; RODRIGUES, 2019a).

Além de produzir esses artigos, o aprofundamento da pesquisadora no tema da compreensibilidade textual em governo eletrônico possibilitou a realização de outros trabalhos profissionais, além da participação em palestras e encontros.

Em 2020, a rotina de pesquisa precisou se adaptar à pandemia da Covid-19. Aulas, debates, reuniões e pesquisas, só por Zoom. Visitas à biblioteca, só em modo drive-thru. Poucos eventos acadêmicos foram realizados, nenhum artigo foi produzido. Felizmente, foi possível participar de seminários, webinários e encontros profissionais online para compartilhar resultados parciais da pesquisa (FISCHER, 2020).

Conforme já foi relatado na seção 7.1., o estudo experimental seria originalmente realizado nos laboratórios da PUC-Rio, usando equipamento de rastreamento ocular (eye tracker). O formato de trabalho remoto demandou mais tempo, mas os objetivos da pesquisa foram plenamente alcançados.

Foi desafiador concluir a fundamentação teórica e realizar o levantamento e o estudo experimental em meio às incertezas e às novas demandas geradas pela pandemia. O cronograma de trabalho sofreu alterações e atrasos. A pesquisa em modo remoto, a sobrecarga de trabalho na rotina profissional fora do mestrado e a interferência das rotinas domésticas foram exaustivas. Esses e outros aspectos foram aprofundados na seção 7.6.4. ("Condições de realização e limitações”).

\section{2.}

\section{Sintonia com o Zeitgeist (espírito do tempo)}

A pandemia acelerou a demanda por saberes e tecnologias que facilitem a compreensão de informações em interfaces digitais. E a facilidade de uso das interfaces passa, necessariamente, pelos elementos linguísticos dos textos. A presente pesquisa integra-se a essa conjuntura comunicacional mais ampla e demonstra estar em sintonia com alguns movimentos relacionados ao campo da Linguagem Simples. 
Está em curso o processo que estabelecerá um padrão normativo da International Organization for Standardization-ISO para a técnica da Linguagem Simples, conforme a seção 4.3. relatou. Quando esta pesquisa foi concluída, em março de 2021, o esboço do padrão estava pronto e seria apresentado ao comitê geral da entidade. Se for aprovado, entrará em vigor nos próximos anos. Tal fato tende a impulsionar o uso da Linguagem Simples em todo o mundo, inclusive em nosso país. A presente pesquisa está em sintonia com este movimento.

A Rede Linguagem Simples Brasil, voltada a conectar pessoas e instituições do setor público interessadas em promover o uso de Linguagem Simples, foi lançada em março de 2021. As principais demandas da rede são materiais informativos e referenciais teóricos. A presente pesquisa está em sintonia com este movimento $^{106}$.

É crescente o interesse de estudantes e professores em investigar o tema da Linguagem Simples sob diferentes perspectivas teóricas (LINCLAB, s/d; GPLS, s/d). A presente pesquisa está em sintonia com este movimento. ${ }^{107}$

As áreas de UX Writing, Legal Design e Visual Law têm relação direta com o uso de Plain Language. Vêm despertando interesse crescente nos setores público e privado no Brasil e no mundo, e têm pouca bibliografia em português. A presente pesquisa tem contribuições a dar a esses campos.

\section{3.}

Frutos

Este estudo gerou frutos conceituais e instrumentais que podem contribuir para informar novas pesquisas e apoiar práticas interessadas na compreensibilidade da informação. A seguir, destacam-se alguns frutos.

Conceituais: A fundamentação teórica sobre compreensibilidade textual (capítulo 2) poderá contribuir para que outras pesquisas sobre Linguagem Simples se apoiem em constructos da Ergonomia, Design da Informação e Psicolinguística. A articulação das três disciplinas fornece subsídios conceituais robustos para

${ }^{106}$ É importante sinalizar que a pesquisadora cofundou a Rede Linguagem Simples Brasil e atua como voluntária no comitê gestor.

${ }^{107}$ É importante sinalizar que a pesquisadora cofundou o mencionado LincLab-Laboratório Interdisciplinar de Linguagem Cidadã. 
avaliar a compreensão de aspectos verbais da informação, especialmente em estudos que lidam com conteúdos de alta complexidade técnica.

A cronologia do movimento internacional de Linguagem Simples (seção 4.2.1.) possibilitou uma visão diacrônica sobre a adoção da técnica pelo setor público. $\mathrm{O}$ entendimento do contexto histórico contribuirá para agentes públicos brasileiros formularem políticas e programas tomando por base processos semelhantes em outros países.

O levantamento documental que compilou diretrizes governamentais de Linguagem Simples em onze governos (capítulo 6) gerou diversos frutos. Ao localizar os setores responsáveis pelas diretrizes na estrutura dos órgãos (seção 6.2), contribuiu para embasar a reflexão sobre onde abrigar o tema dentro da máquina pública. Tal informação pode acelerar processos de implantação de Linguagem Simples em órgãos governamentais. Já os quadros de diretrizes por área de concentração e a lista das 12 diretrizes governamentais mais recorrentes (seção 6.4) geraram parâmetros para grupos informais, organizações públicas, privadas e do terceiro setor estruturarem os seus próprios programas de Linguagem Simples.

Instrumentais: A análise das características linguísticas do burocratês gerou um quadro com elementos linguísticos que prejudicam a compreensão leitora em três idiomas (seção 3.2, Quadro 1). Esse material poderá contribuir para alertar comunicadores sobre os elementos que dificultam a leitura e, muitas vezes, passam despercebidos em seus textos.

Foi composto um check-list para analisar a complexidade de textos (seção 7.3.2.1.), formado por métricas da ferramenta computacional Coh-Metrix Port 3.0 e diretrizes governamentais de Linguagem Simples resultantes do levantamento documental. O check-list poderá ter utilidade em outros estudos sobre compreensibilidade textual da informação. Também poderá ser usado como uma ferramenta auxiliar para verificar a complexidade da comunicação verbal por qualquer pessoa interessada em tornar a sua escrita mais fácil de ler e entender.

\section{4 .}

Desdobramentos e recomendações 
O presente trabalho propôs-se a cobrir um escopo amplo e está consciente de suas limitações. Sendo a Linguagem Simples um campo de investigação ainda incipiente e potencialmente vasto, os leitores deste trabalho conseguirão entrever inúmeros desdobramentos possíveis.

A pesquisadora indica alguns desdobramentos que identificou ao longo da investigação, organizando-os por campo: Design, Psicolinguística e Governo eletrônico.

\section{DESIGN}

- Impacto combinado de aspectos verbais, aspectos visuais (gráficos/ tipográficos) e padrões de leitura web na compreensibilidade de eserviços: O foco do presente estudo foi em aspectos verbais do texto dos serviços públicos digitais. Abriu-se mão de investigar o efeito combinado de aspectos visuais do Design da Informação e dos padrões de leitura web na compreensão de textos governamentais porque, para o escopo de uma dissertação de mestrado, não seria possível conduzir um segundo estudo experimental, em que aspectos visuais fossem tomados como variáveis independentes. Isso exigiria uma ampliação importante do número de participantes. Ocorre que os aspectos visuais e os padrões de leitura são igualmente significativos para a compreensibilidade textual. É recomendável que pesquisas futuras busquem aferir o impacto combinado desses fatores;

- Design de e-serviços e facilidade de uso: Na revisão de literatura sobre serviços públicos digitais, a pesquisadora recolheu estudos que abordam a criação de valor público relacionada ao design dos e-serviços (LOPES, 2016; LOPES; MACADAR; LUCIANO, 2018a e b.). Os estudos consideram que a facilidade de uso do serviço público digital deve ser projetada por design. Mas o papel do texto, mesmo sendo um elemento constitutivo da percepção de facilidade de uso, ficou fora do escopo daqueles estudos. A pesquisadora chegou a publicar um trabalho tocando no tema (FISCHER; MONT'ALVÃO; RODRIGUES, 2019c), mas a discussão não chegou a ser incorporada a esta dissertação. É um tema relevante que merece ser pesquisado. 


\section{PSICOLINGUÍSTICA}

- Uso de rastreador ocular em metodologia semelhante: Como já dito, o projeto original do estudo experimental previa usar rastreador ocular (eye tracker) para conhecer diferenças entre padrões de leitura do Texto Burocratês e do Texto Simplificado. A pandemia de Covid19 impediu o acesso ao campus da PUC-Rio e o uso do equipamento nos laboratórios. Seria relevante aproveitar a metodologia desenvolvida na presente pesquisa, agregando o rastreamento ocular, quando as condições sanitárias permitirem.

- Correlações entre conteúdo informacional e estrutura linguística do teste de compreensão: Não houve tempo hábil para analisar possíveis correlações entre o conteúdo informacional das 12 afirmativas do teste de compreensão e as estruturas linguísticas correspondentes nos Textos Burocratês e Simplificado. O quadro que consta do Apêndice 3 foi um primeiro passo nesse sentido. Seria proveitoso investigar essas correlações que ficaram pendentes.

\section{GOVERNO ELETRÔNICO}

- Estados de espírito e crenças do usuário que interferem na adesão a e-serviços: O capítulo 2 mencionou aspectos estudados pelo Design da Informação e pela Ergonomia que derivam da interação com o texto e impactam na compreensibilidade da informação. Um aspecto é o que Pettersson (2015, p. 88) chama de "comunicação unidirecional", causada por linguagem técnica e jargão. O estilo textual alijaria o leitor do texto, levando-o a um estado de espírito defensivo e intransigente que prejudicaria a compreensão da mensagem. Outro aspecto está no modelo de Wogalter (2006, apud MONT'ALVÃO 2020): o processamento da informação baseia-se em atitudes e crenças do receptor que influenciam o processamento da informação, gerando (ou não) comportamentos. Some-se ainda a motivação para assimilar a mensagem transmitida. Neste sentido, Schriver (1997) oferece boas reflexões sobre a forma como leitores formam a sua impressão a respeito de documentos. Parece ser 
oportuno investigar tais aspectos no contexto da informação em governo eletrônico.

- Pesquisa survey para qualificar a experiência com serviços públicos digitais: Participantes do estudo experimental foram solicitados a citar dois adjetivos que qualificassem uma experiência recente com serviços públicos digitais, conforme detalhado na seção 7.5.8. Parece ser conveniente replicar essa avaliação em uma pesquisa do tipo survey, ou seja, usando um questionário estruturado para coletar dados quantitativos em grande escala.

- Uso de burocratês na perspectiva de servidores públicos: As críticas ao burocratês concentram-se nos efeitos deletérios à compreensão, desconsiderando o contexto de redação dos textos. O uso de um estilo tão próximo da linguagem jurídica na comunicação com os cidadãos pode decorrer da cautela de servidores públicos com a responsabilidade civil que é atrelada a seus atos. Seria recomendável conhecer o que os servidores têm a dizer a esse respeito, para chegarse a uma visão mais completa do problema que a Linguagem Simples procura resolver.

- Debate crítico sobre adoção de Linguagem Simples em governos: A presente pesquisa fez um brevíssimo compilado das visões críticas ao movimento e à técnica da Linguagem Simples (seção 4.4.). Esse debate tem grande relevância social, especialmente no que diz respeito à aplicação no setor público, mas parece ainda ter pouco espaço. O pensamento crítico enriquece qualquer campo de saber. Seria conveniente aprofundar os pontos críticos mapeados pela presente pesquisa em um estudo à parte.

- Formação de redes latino-americanas de Linguagem Simples: Conforme foi relatado na seção 4.2.1., os últimos anos viram surgir redes institucionais de Linguagem Simples no Chile, Argentina e Colômbia, ligadas ao poder público. Já a seção 4.5 relatou o surgimento de uma rede semelhante no Brasil. Seria proveitoso conhecer e relatar o processo de formação dessas redes a fim de 
compreender os percursos e percalços de cada uma. Deste modo, seriam gerados subsídios para outras redes em formação.

\section{5.}

\section{Conclusões}

A principal meta do governo eletrônico é que cidadãos e empresas processem serviços, realizem transações ou consultem informações por meio de autoatendimento digital, sozinhos, sem recorrer a suporte humano para esclarecer dúvidas. Ocorre que muitos trâmites burocráticos antigos são disponibilizados online sem passar por redesenhos de simplificação, mantendo o estilo textual prolixo que sempre caracterizou os governos. Mas, na época dos balcões de atendimento, era possível esclarecer presencialmente as dúvidas causadas pelo burocratês e não era necessário conhecer a engrenagem da máquina pública: quem trabalhava nos órgãos processava as demandas da população. Já não é mais assim.

Vem crescendo a proporção de brasileiros que não interagem com governo eletrônico por considerarem difícil encontrar os serviços de que precisam. Eram $25 \%$ em 2017, passaram a ser $33 \%$ em 2019. Um grande percentual dos usuários de internet evita o autoatendimento online por achar o contato com o governo pela internet complicado (55\%).

Tal contexto revela os contornos cívicos da compreensibilidade textual que a transformação digital potencializou e a pandemia da Covid-19 acelerou.

Já que ler, entender e processar informações públicas no próprio celular ou computador tornou-se uma questão de cidadania, governos devem se esforçar para oferecer serviços online fáceis de utilizar. É preciso usar uma linguagem menos técnica e mais objetiva, além de promover as habilidades que a cidadania online requer. A vulnerabilidade digital é vultuosa e causa inúmeros prejuízos sociais.

Este estudo construiu um conjunto de argumentos para sustentar a relevância do estilo textual na compreensibilidade da informação em governo eletrônico. Examinou detalhadamente como a Ergonomia, o Design da Informação e a Psicolinguística abordam custos de processamento mental, exigências de memória de trabalho e sobrecarga cognitiva durante a leitura. Também fez uma análise minuciosa dos elementos que caracterizam o linguajar da burocracia. A partir de 
trabalhos de linguistas em três idiomas, foi possível mapear os efeitos deletérios do burocratês no processamento mental e na compreensão das informações mesmo em leitores avançados.

A pesquisa mostrou que existem no Brasil leis e normativos determinando linguagem fácil de entender na informação de governo eletrônico há mais de vinte anos. Mesmo sendo um problema antigo e grave, persiste uma certa desatenção e insensibilidade de agentes públicos para as dificuldades que a população enfrenta, pois a informação governamental continua sendo escrita em burocratês. Liljestrand e Arwidsson (1979 apud PETTERSSON 2015) alertam que "é certamente mais razoável esperar que uma pessoa ponha esforço na escrita de seu texto, do que os vários destinatários sejam obrigados, cada um por si, a gastar esforço para interpretá-lo". Mas os governos parecem discordar disso.

A tolerância dos agentes públicos com a incompreensibilidade textual talvez se justifique por textos em burocratês fazerem parte da paisagem governamental. Parafraseando a designer da informação Karen Schriver, na epígrafe desta dissertação, decifrar a má escrita e o mau design visual se tornaram parte das habilidades necessárias para lidar com governo eletrônico. Outra possível justificativa seria a falta de empatia de agentes públicos com as dificuldades da população, dada a sua percepção autorreferenciada do burocratês. Eles próprios possivelmente teriam dificuldade de compreender a informação governamental se o conteúdo não lhes fosse tão familiar.

A presente investigação gerou evidências de que a linguagem característica do setor público segrega até mesmo leitores altamente proficientes. O estudo experimental mostrou que adultos com pós-graduação em curso ou completa, representantes do topo da pirâmide educacional brasileira, têm dificuldade para processar o texto sobre o Auxílio-doença conforme publicado no site do INSS, em burocratês. A maioria teve dúvidas sobre o entendimento das informações após reler o texto. Eles desempenharam pior e demoraram mais no teste de compreensão do que um outro grupo de leitores igualmente proficientes que leu o texto reescrito em Linguagem Simples. Mais de $50 \%$ dos leitores da versão simplificada concluíram o teste de compreensão de informações tendo lido o texto apenas uma vez, o que só ocorreu com $25 \%$ dos que leram a versão original em burocratês. Os resultados do experimento tiveram relevância estatística. 
A percepção de textos governamentais na internet serem confusos e difíceis de entender prevaleceu entre todos os participantes do experimento, que preferem buscar informações no Google a acessar os sites dos órgãos. A avaliação da experiência de uso de serviços públicos digitais foi $79 \%$ negativa. Os adjetivos mais mencionados para qualificar a experiência foram "confusa" e "estressante".

Além de mostrar a ampla extensão do problema causado pela incompreensibilidade textual em e-gov, a pesquisa também gerou evidências documentais para auxiliar governos que desejem aderir ao movimento Linguagem Simples. O estudo compilou as diretrizes que são mais recorrentes em onze governos e confirmou que elas enfrentam os problemas mais comuns do burocratês, conforme apontados por linguistas.

Quando surgiu, nos anos 1940, o movimento Linguagem Simples enfatizava aspectos lexicais e sintáticos, mesmo sem ter sido constituído com a participação de linguistas. A pesquisa mostrou que a técnica foi assimilando diretrizes de outros campos do saber com o passar das décadas, tendo contado com a contribuição ativa de designers. A partir dos anos 1970, foram sendo incorporadas diretrizes de Design da Informação e, depois, de Usabilidade.

Este estudo mostrou que Plain Language, Design da Informação e Psicolinguística têm uma ligação histórica e, por isso, é curioso observar que ainda exista a percepção que aspectos verbais e aspectos visuais de um documento devam ser tratados de forma apartada. A presente pesquisa espera contribuir para a aproximação maior desses campos do saber e colaborar para a plena assimilação de políticas públicas em prol de informações claras e de fácil compreensão. 


\section{Referências bibliográficas}

$3^{\circ}$ ENCONTRO Brasileiro de Governo Aberto. Só é acessível se der para entender: Linguagem Clara já!. Mesa redonda. Heloisa Fischer, Aureliano Junior e Marco Nieto.

São Paulo, 5 dezembro 2018. Disponível em: https://governoaberto.sched.com/ event/J1dM/so-e-acessivel-se-der-para-entender-linguagem-clara-ja . Acesso em: 28 fev. 2021.

18F. Use Plain Language. Disponível em: https://content-guide.18f.gov/our-approach/ plain-language/. Acesso em: 2 mar. 2021.

AITCHISON, Jean. The Gobbledygook Syndrome. English Today, [s. l.], v. 2, n. 1, p. 7-9, January 1986. DOI 10.1017/S0266078400001619. Disponível em: http://journals. cambridge.org/abstract_S0266078400001619 . Acesso em: 5 mar. 2021

AMA - AGÊNCIA PARA A MODERNIZAÇÃO ADMINISTRATIVA. 10 Guias Orientadoras de Linguagem. Disponível em: https://cloud.ama.gov.pt/index.php/s/ hauYjfhcxWdj8FR/authenticate (usar a senha "guias", sem as aspas). Acesso em: 28 fev. 2021.

AMA - AGÊNCIA PARA A MODERNIZAÇÃO ADMINISTRATIVA. EPortugal. Disponível em: https://www.ama.gov.pt/web/agencia-para-a-modernizacao-administ rativa/eportugal \#: :text $=\mathrm{Com} \% 20 \mathrm{o} \% 20 \mathrm{ePortugal} \% 2 \mathrm{C} \% 20 \mathrm{as} \% 20 \% \mathrm{EF} \% \mathrm{AC} \% 81 \mathrm{chas}, \mathrm{d}$ e\%20Cidad\%C3\%A30\%2C\%20a\%20Bolsa\%20de . Acesso em: 2 mar. 2021.

American Heritage Dictionary of the English Language. Fifth Edition. Boston: Houghton Mifflin, 2016.

ANUÁRIO Estatístico da Previdência Social 2018. Brasília: Ministério da Fazenda, Secretaria de Previdência, Empresa de Tecnologia e Informações da Previdência, 2019. 1048 p. v. 25 . Disponível em: https://www.gov.br/previdencia/pt-br/acesso-ainformacao/dados-abertos/previdencia-social-regime-geral-inss/arquivos/aeps-2018.pdf . Acesso em: 5 mar. 2021.

APPADURAI, Arjun. Banking on words: The failure of language in the age of derivative finance. Chicago \& London: The University of Chicago Press, 2016.

ARGENTINA.GOB.AR. Lenguaje Simples. Disponível em: https://www.argentina .gob.ar/contenidosdigitales/comunicar/lenguaje-simple . Acesso em: 2 mar. 2021.

ASPREY, Michelle. Plain Language for Lawyers. Annandale: The Federation Press, 2010.

AUStRalian GOVERnMENT. Digital Guides - Writing Style. Disponível em: https://www.guides.service.gov.au/content-guide/writing-style . Acesso em: $28 \mathrm{fev}$. 2021. 
AUXÍLIO Emergencial chega a $60 \%$ da população brasileira. Portal Gov.br - Notícias. Publicado em 21/08/2020. Disponível em: https://www.gov.br/pt-br/noticias/financasimpostos-e-gestao-publica/600-dias/arquivos-de-600-dias/cidadania-auxilioemergencial-chega-a-60-da-populacao-brasileira. Acesso em: 05 mar. 2021

BAER, Kim. Information Design Workbook: Graphic approaches, solutions, and inspiration +30 case studies. Beverly: Rockport Publishers, 2009. 240 p. ISBN 978-159253-627-6.

BALMFORD, Christopher. An ISO Plain Language Standard. Site International Plain Language Federation. 7 set. 2020. Disponível em:https://www.iplfederation.org/an-isoplain-language-standard/\#: : text=The $\% 20$ International $\% 20$ Standards $\% 20$

Organization $\% 20 \% \mathrm{E} 2 \% 80 \% 95 \% 20 \mathrm{known}$,as $\% 20$ many $\% 20$ languages $\% 20$ as $\% 20$ possib le.\&text $=$ The $\% 20$ Working $\% 20$ Group $\% 20$ is $\% 20$ part,which $\% 20$ covers $\% 20$ Language $\% 2$ 0and\%20terminology . Acesso em: 28 fev. 2020.

BARBOZA, Elza Maria Ferraz. A linguagem clara em conteúdos de websites governamentais para promover a acessibilidade a cidadãos com baixo nível de escolaridade. Inclusão Social, Brasília, ano 2010, v. 4, n. 1, Julho 2011. Disponível em: http://revista.ibict.br/inclusao/article/view/1644 . Acesso em: 3 mar. 2021.

BARBOZA, Elza Maria Ferraz; NUNES, Eny Marcelino de Almeida. A inteligibilidade dos websites governamentais brasileiros e o acesso para usuários com baixo nível de escolaridade. Inclusão Social, Brasilia, ano 2007, v. 2, n. 2, p. 19-33, 7 maio 2008. Disponível em: http://revista.ibict.br/inclusao/article/view/1599 . Acesso em: $28 \mathrm{fev}$. 2021.

BBC NEWS. Plain speaking is no joke. BBC News Website, 10 dez. 1997. Disponível em: http://news.bbc.co.uk/2/hi/uk_news/38503.stm . Acesso em: 9 mar. 2021.

BECKER, Lidia. "Lectura Fácil" o "Lenguaje Ciudadano / Llano / Claro": ¿una nueva variedad del español adaptada a los medios de comunicación digitales?. In: COLOQUIO INTERNACIONAL "EL PLURICENTRISMO DE LA CULTURA LINGÜÍSTICA HISPÁNICA. REFLEJOS EN LOS MEDIOS DE COMUNICACIÓN MASIVA", 2016, Bonn. Resúmenes de las ponencias $[\ldots] . \quad[S . \quad l .: s . \quad n]$, 2016. Disponível em: https://www.pluricentrismo.uni-bonn.de/Coloquio_pluricentrismo_Abstracts.pdf

Acesso em: 1 mar. 2021.

BLACK, Alison. LUNA, Paul. LUND, Ole. WALKER, Sue (Eds). Information Design - research and practice. Routledge, London and New York, 2017.

BRASIL. Decreto $\mathbf{N}^{0}$ 6.932, de 11 de agosto de 2009. Dispõe sobre a simplificação do atendimento público prestado ao cidadão, ratifica a dispensa do reconhecimento de firma em documentos produzidos no Brasil, institui a "Carta de Serviços ao Cidadão" e dá outras providências. Disponível em: https:/www.planalto.gov.br/ccivil 03/_ato20072010/2009/decreto/d6932.htm . Acesso em: 5 mar. 2021.

BRASIL. Decreto $\mathbf{n}^{\mathbf{0}}$ 8.414, de 26 de fevereiro de 2015. Institui o Programa Bem Mais Simples Brasil e cria o Conselho Deliberativo e o Comitê Gestor do programa. Disponível em: 
https://legislacao.presidencia.gov.br/atos/?tipo $=$ DEC\&numero $=8414 \& a n o=2015 \& a t o=2$ a9ATS610dZpWT672 . Acesso em: 1 mar. 2021.

BRASIL. Decreto $n^{0}$ 8.638, de 15 de janeiro de 2016 (Revogado pelo Decreto $\mathbf{n}^{\circ}$ 10.332, de 2020). Institui a Política de Governança Digital no âmbito dos órgãos e das entidades da administração pública federal direta, autárquica e fundacional. [S. l.], 18 mar. 2021. Disponível em: http://www.planalto.gov.br/ccivil 03/ato2015-2018/2016/ decreto/d8638.htm . Acesso em: 28 fev. 2021

BRASIL. Decreto $\mathbf{n}^{0}$ 10.332, de 28 de abril de 2020. Institui a Estratégia de Governo Digital para o período de 2020 a 2022, no âmbito dos órgãos e das entidades da administração pública federal direta, autárquica e fundacional e dá outras providências. Disponível em: http:/www.planalto.gov.br/ccivil 03/Ato2019-2022/2020/Decreto/ D10332.htm. Acesso em: 3 mar. 2021.

BRASIL. Lei complementar $n^{0}$ 95, de 26 de fevereiro de 1998. Dispõe sobre a elaboração, a redação, a alteração e a consolidação das leis, conforme determina o parágrafo único do art. 59 da Constituição Federal, e estabelece normas para a consolidação dos atos normativos que menciona. Disponível em: http://www. planalto.gov.br/ccivil_03/leis/lcp/lcp95.htm . Acesso em: 5 mar. 2021.

BRASIL. Lei $\mathbf{n}^{0} \mathbf{1 0 . 0 9 7}$, de 19 de dezembro de 2000. Altera dispositivos da Consolidação das Leis do Trabalho - CLT, aprovada pelo Decreto-Lei no 5.452, de $1^{\circ}$ de maio de 1943. Disponível em: http://www.planalto.gov.br/ccivil_03/leis/110097.htm . Acesso em: 1 mar. 2021.

BRASIL. Lei $\mathbf{n}^{0}$ 12.527, de 18 de novembro de 2011. Regula o acesso a informações previsto no inciso XXXIII do art. $5^{\circ}$, no inciso II do $\S 3^{\circ}$ do art. 37 e no $\S 2^{\circ}$ do art. 216 da Constituição Federal; altera a Lei no 8.112, de 11 de dezembro de 1990; revoga a Lei $\mathrm{n}^{\mathrm{o}} 11.111$, de 5 de maio de 2005, e dispositivos da Lei $\mathrm{n}^{\mathrm{o}} 8.159$, de 8 de janeiro de 1991; e dá outras providências. Disponível em: http://www.planalto.gov.br/ccivil 03/ ato20112014/2011/lei/112527.htm . Acesso em: 22 fev. 2021.

BRASIL. Lei $\mathbf{n}^{\mathbf{0}}$ 12.796, de 4 de abril de 2013. Altera a Lei n ${ }^{0} 9.394$, de 20 de dezembro de 1996, que estabelece as diretrizes e bases da educação nacional, para dispor sobre a formação dos profissionais da educação e dar outras providências. Disponível em: http://www.planalto.gov.br/ccivil_03/_Ato2011-2014/2013/Lei/L12796.htm\#art1

Acesso em: 1 mar. 2021.

BRASIL. Lei no 13.146, de 6 de julho de 2015. Institui a Lei Brasileira de Inclusão da Pessoa com Deficiência (Estatuto da Pessoa com Deficiência). Diário Oficial da União, 7 jul. 2015. Disponível em: http://www.planalto.gov.br/ccivil_03/_ato2015-2018/2015/ lei/113146.htm . Acesso em: 22 fev. 2021.

BRASIL. Lei no 13.460, de 26 de junho de 2017. Dispõe sobre participação, proteção e defesa dos direitos do usuário dos serviços públicos da administração pública. Diário Oficial da União, 27 jun. 2017. Disponível em: http://www.planalto.gov.br/ccivil_03/ ato2015-2018/2017/lei/113460.htm . Acesso em: 22 fev. 2021. 
BRASIL. Lei $n^{0}$ 13.709, de 14 de agosto de 2018. Lei Geral de Proteção de Dados Pessoais (LGPD). Diário Oficial da União, 15 ago. 2018. Disponível em: http://www.planalto.gov.br/ccivil_03/_ato2015-2018/2018/lei/L13709.htm . Acesso em: 1 mar. 2021.

BRIDGER, R.S. Introduction to Ergonomics. Singapore: McGraw-Hill, 1995. 529 p. ISBN 0-07-113294-5.

BROADBENT, D.E. Language and ergonomics. Applied Ergonomics, [s. l.], p. 15-18, March 1977.

BRYSBAERT, Marc; NEW, Boris. Moving beyond Kucera and Francis: A critical evaluation of current word frequency norms and the introduction of a new and improved word frequency measure for American English. Behavior Research Methods, [s. l.], v. 41, n. 4, p. 977-990, 2009. DOI 10.3758/BRM.41.4.977. Disponível em: https://www.researchgate.net/publication/38075028_Moving_beyond_Kucera and_Fra ncis_A_Critical_Evaluation_of_Current_Word_Frequency_Norms and the Introductio n of a N New and Improved Word_Frequency Measure for_American_English Acesso em: 2 mar. 2021.

BURGESS, Curt; LIVESAY, Kay. The effect of corpus size in predicting reaction time in a basic word recognition task: Moving on from Kucera and Francis. Behavior Research Methods, Instruments, \& Computers, [s. l.], v. 30, n. 2, p. 272-277, 1998. DOI 10.3758/BF03200655. Disponível em: https://www.researchgate.net/publication/ 226260797 The effect of corpus size in predicting reaction time in a basic word recognition task_Moving_on_from_Kucera and_Francis . Acesso em: 4 mar. 2021.

CASABONE, Griselda. El lenguaje burocrático como género: Una lectura crítica sobre las escrituras de la modernidad. Oficios Terrestres, Buenos Aires, n. 35, 2016. Disponível em: https://perio.unlp.edu.ar/ojs/index.php/oficiosterrestres/article/view/ 3567/3401. Acesso em: 5 mar. 2021.

CAIXA Econômica Federal. Auxílio emergencial. Disponível em: https://www.caixa. gov.br/auxilio/PAGINAS/DEFAULT2.ASPX . Acesso em: 05 mar. 2021

CÂMARA DOS DEPUTADOS. Projeto de Lei $\mathbf{n}^{\mathbf{0}}$ 6256/2019, de 3 de dezembro de 2019. Institui a Política Nacional de Linguagem Simples nos órgãos e entidades da administração pública direta e indireta. Brasília, 3 dez. 2019. Disponível em: https://www.camara.leg.br/proposicoesWeb/fichadetramitacao?idProposicao=2231632 . Acesso em: 1 mar. 2021.

CANADA.CA. Canada.ca Content Style Guide. Disponível em: https://www. canada.ca/en/treasury-board-secretariat/services/government-communications/canadacontent-style-guide.html . Acesso em: 28 fev. 2021.

CHAPANIS, Alphonse. Words, Words, Words. Human Factors, [s. l.], p. 1-17, February 1965.

CLARITY. About Clarity. Disponível em: https://www.clarity-international.org/aboutclarity/. Acesso em: 28 fev. 2021. 
CONTENT DESIGN LONDON. Readability Guidelines. Disponível em: https:// readabilityguidelines.co.uk . Acesso em: 28 fev. 2021.

COOLICAN, Hugh. Research Methods and Statistics in Psychology. 6. ed. London and New York: Psychology Press, 2014. 788 p. ISBN 978-0-203-76983-6.

CRESWELL, John W. Research Design - Qualitative, Quantitative, and Mixed Methods Approaches. Third Edition. Thousand Oaks: Sage Publications, 2009.

CUESTA, Ana; REYES, Angela; ROSETH, Benjamin. The Importance of Clarity: Impacts of Colombia's Lenguaje Claro Program on Reducing Administrative Burdens. [S. l.]: Inter-American Development Bank, May 2019. Disponível em: https:// publications.iadb.org/en/importance-clarity-impacts-colombias-lenguaje-claro-programreducing-administrative-burdens . Acesso em: 1 mar. 2021.

CUTTS, Martin. Oxford Guide to Plain English. 4 ${ }^{\text {a }}$ ed. Oxford: Oxford University Press, 2013. ISBN 978-0-19-966917-2.

DANET, Brenda. Law, Bureaucracy, and Language. Society, [s. l.], ed. 20, p. 49-55, May-June 1983. Disponível em: https://link.springer.com/article/10.1007\%2FBF 02697860 . Acesso em: 5 mar. 2021.

DE MIGUEL, Elena. El texto jurídico-administrativo: Análisis de una orden ministerial. CLAC : Círculo de lingüística aplicada a la comunicación, [s. l.], ed. 4, 2000. Disponível em: https://webs.ucm.es/info/circulo/no4/demiguel.htm . Acesso em: 1 mar. 2021.

DE MORAES, Antonio Ermírio. Um quarteto do barulho. Folha de S.Paulo, São Paulo, 15 jan. 1995. Disponível em: https://www1.folha.uol.com.br/fsp/1995/1/15/ opiniao/6.html . Acesso em: 1 mar. 2021.

DE MORAES, Anamaria; MONT'ALVÃO, Claudia. Ergonomia: Conceitos e Aplicações. $4^{\mathrm{a}}$ edição. ed. rev. e aum. Teresópolis: 2AB, 2010. 224 p. ISBN 978-8586695-49-0.

DE MORAES, Anamaria. Ergonomia Informacional: A Comunicação Humano-TarefaMáquina; Pensamento, Convergência e Mudança de Comportamento. In: DE MORAES, Anamaria (Org.). Avisos, Advertências e Projeto de Sinalização. Rio de Janeiro: IUsEr, 2002. p. 7-29.

DEPARTAMENTO NACIONAL DE PLANEACIÓN. (Colombia). Guía de Lenguaje Claro para Servidores Públicos de Colombia: \#YoSirvoParaLaPaz. Bogotá: DNPDepartamento Nacional de Planeación, 2015. 52 p. ISBN 978-958-8340-81-4. Disponível em:

https://colaboracion.dnp.gov.co/CDT/Programa $\% 20$ Nacional $\% 20 \mathrm{del} \% 20$ Servicio $\% 20 \mathrm{al}$ \%20Ciudadano/GUIA\%20DEL\%20LENGUAJE\%20CLARO.pdf . Acesso em: 4 mar. 2021. 
DIGITAL.GOVT.NZ. Plain Language. Disponível em: https://www.digital.govt.nz/ standards-and-guidance/design-and-ux/content-design-guidance/writing-style/plainlanguage. Acesso em: 28 fev. 2021.

DNP-DEPARTAMENTO NACIONAL DE PLANEACIÓN. 10 pasos para comunicarse en lenguaje claro. Disponível em: https://colaboracion.dnp.gov.co/ CDT/Programa\%20Nacional\%20del\%20Servicio\%20al\%20Ciudadano/10\%20PASOS. pdf. Acesso em: 28 fev. 2021.

DNP - DEPARTAMENTO NACIONAL DE PLANEACÍON. Lenguage Claro - ¿Qué es Lenguaje Claro?. Disponível em: https://www.dnp.gov.co/programa-nacional-delservicio-al-ciudadano/Paginas/Lenguaje-Claro.aspx . Acesso em: 28 fev. 2021

DUBAY, William H. The Principles of Readability. Costa Mesa: Impact Information, 2004. Disponível em: http://www.impact-information.com/impactinfo/readability02.pdf . Acesso em: 5 mar. 2021.

DUFFY, Thomas M. Readability Formulas: What's the Use? In: DUFFY, Thomas M.; WALLER, Robert (ed.). Designing Usable Texts. [S. l.]: Academic Press, 1985. cap. 6, p. 113-143. ISBN 978-0-12-223260-2.

ENCONTRO Internacional de Inovação em Governo, 2019. Vídeo da mesa "Como a linguagem pode ajudar o governo a se relacionar melhor com a sociedade?". Heloisa Fischer, Aura Cifuentes e Vitor Fazio. São Paulo, 9 ago. 2019. Disponível em: https://www.youtube.com/watch?v=gRQVnLEJ1U8\&list=PL1plg4ukJWGxgOvmw8f8 KNabmR0KtW0V5\&index=16 . Acesso em: 28 fev. 2021.

E-SIC CGU. [Sistema Acesso a Informação - 03006.000460/2019-94 - Pedido Respondido]. Destinatário: helofischer@gmail.com. 30 jul.2020. 1 email.

EVANS, Martin. Technical Paper 8: Criteria for clear documents: a survey. Simplification Center: $\left[\begin{array}{ll}s . & n .]\end{array}\right]$ April 2011. Disponível em: https://www. simplificationcentre.org.uk/reports $2 /$ technical-paper-8-criteria-for-clear-documents-asurvey . Acesso em: 4 mar. 2021.

FISCHER, Heloisa. Clareza em textos de e-gov, uma questão de cidadania: Subsídios do movimento mundial pela linguagem clara para facilitar a compreensão de textos que orientam cidadãos em ambientes de governo eletrônico. Rio de Janeiro: Com Clareza, 2018. $84 \mathrm{p}$.

FISCHER, Heloisa. Como foi 2019 até aqui. In: COMUNICA SIMPLES. Blog. 5 ago. 2019. Disponível em: https://comunicasimples.com.br/2019/08/05/como-foi-2019-ateaqui/. Acesso em: 1 mar. 2021.

FISCHER, Heloisa. Textos incompreensíveis prejudicam a cidadania. In: $5^{\text {a }}$ SEMANA DE INOVAÇÃO EM GESTÃO PÚBLICA, 2019, Brasília. Video da palestra [...]. Disponível em: https://www.youtube.com/watch?v=klvHpe5-tp8\&list=PL1plg4ukJWG xgOvmw8f8KNabmR0KtW0V5\&index=17 . Acesso em: 1 mar. 2021. 
FISCHER, Heloisa; MONT'ALVÃO, Claudia; RODRIGUES, Erica dos Santos. A Linguagem Simples no legislativo: três exemplos sul-americanos. In: Resumos da $\mathbf{X}$ Jornada de Pesquisa e Extensão do Centro de Formação da Câmara dos Deputados. Brasília: Câmara dos Deputados, 2019. Disponível em: https://soac.camara .gov.br/index.php/Jornada/X/paper/view/322. Acesso em: 6 mar. 2021.

FISCHER, Heloisa; MONT'ALVÃO, Claudia; RODRIGUES, Erica dos Santos. Evaluating the impact of Plain Language on the comprehensibility of e-gov texts. In: SENSES \& SENSIBILITY '19: LOST IN (G)LOCALIZATION, 10., 2019, Lisboa. Proceedings [...]. Lisboa: UNIDCOM Iade, 2020. p. 288-296. Disponível em: http://senses2019.unidcom-iade.pt/wp-content/uploads/2020/12/Proceedings-of-the10th-International-Conference-SensesSensibility-2019-Lost-in-Glocalization-finalversion medium.pdf . Acesso em: 1 mar. 2021.

FISCHER, Heloisa; MONT’ALVÃO, Claudia; RODRIGUES, Erica dos Santos; Fator facilitador ou barreira para cidadãos acessar em e serviços: o papel do texto em governo eletrônico, p. 250-265 . In: Anais do $17^{\circ}$ Congresso Internacional de Ergonomia e Usabilidade de Interfaces Humano-Tecnologia e o $17^{\circ}$ Congresso Internacional de Ergonomia e Usabilidade de Interfaces e Interação Humano-Computador. São Paulo: Blucher, 2019. ISSN 2318-6968, DOI 10.5151/ergodesign2019-2.19. Disponível em: $\quad$ https://www.proceedings.blucher.com.br/article-details/f-ator-facilitador-oubarreira-para-cidados-acessar-em-e-servios-o-papel-d-o-texto-em-governo-eletrnico34112. Acesso em: 2 mar. 2021.

FISCHER, Heloisa; MONT'ALVÃO, Claudia; RODRIGUES, Erica dos Santos; ENGELKE, Antonio. Compreensibilidade em textos de e-gov: uma análise exploratória da escrita do INSS, p. 303-313. In: Anais do $9^{\circ}$ CIDI | Congresso Internacional de Design da Informação, edição 2019 e do $9^{\circ}$ CONGIC | Congresso Nacional de Iniciação Científica em Design da Informação. São Paulo: Blucher, 2019. ISSN 23186968. DOI 10.5151/9cidi-congic-1.0306. Disponível em: https://www.proceedings. blucher.com.br/article-details/compreensibilidade-em-textos-de-e-gov-uma-anliseexploratria-da-escrita-do-inss-33627 . Acesso em: 2 mar. 2021.

FRASCARA, Jorge. Communication design: principles, methods, and practice. New York: Allworth Press, 2004. 208 p. ISBN 1-58115-365-1.

FUNDAÇÃO SEADE. Orientações para adoção de linguagem clara. [S. $l::$ s. $n$.], 2016. Disponível em: http://www.governoaberto.sp.gov.br/wp-content/uploads/2017/12/ orientacoes_para_adocao_linguagem_clara_ptBR.pdf. Acesso em: 1 mar. 2021.

GARWOOD, Kimberley Christine. Plain, But Not Simple: Plain Language Research with Readers, Writers, and Texts. 276 p. Thesis (Doctor of Philosophy in English) University of Waterloo, Waterloo, Canada, 2014. Disponível em: http://hdl.handle.net/10012/8401 . Acesso em: 2 mar. 2021.

GESPÚBLICA - PROGRAMA NACIONAL DE GESTÃO PÚBLICA E DESBUROCRATIZAÇÃO. Fugindo do "burocratês": como facilitar o acesso do cidadão ao serviço público: Dicas de como comunicar um serviço público para o seu público-alvo utilizando linguagem cidadã. $[S . l$.$] : Ministério do Planejamento,$ Desenvolvimento e Gestão, 2016. Disponível em: http://www.gespublica. 
gov.br/sites/default/files/documentos/linguagem_cidada _ versao final_web.pdf Acesso em: 22 fev. 2021.

GOBBLEDYGOOK. Public Administration Review, [s. l.], v. 4, n. 2, p. 151-152, Spring 1944.

GORE, Al. Access America: Reengineering Through Information Technology: Report of the National Performance Review and the Government Information Technology Services Board. [S. l.]: National Performnace Review, Fevereiro 1997. 113 p. Disponível em: https://govinfo.library.unt.edu/accessamerica/reports/access.html . Acesso em: 28 fev. 2021

GOUVEIA, Carlos A. M. Texto e Gramática: Uma introdução à Linguística Sistémicofuncional. Matraga, Rio de Janeiro, v. 16, n. 24, p. 13-47, jan./jun. 2009. DOI 10.12957/matraga. Disponível em: https://www.e-publicacoes.uerj.br/index.php/ matraga/article/view/27795 . Acesso em: 10 mar. 2021.

GOV.BR. Guia de Edição de Serviços do Portal Gov.br. Disponível em: https://www.gov.br/pt-br/guia-de-edicao-de-servicos-do-gov.br . Acesso em: 28 fev. 2021.

GOVERNMENT OF CANADA. Communications Policy of the Government of Canada: Rescinded [2016-05-11]. [S. l.: s. n.], 2006. Disponível em: https://www.tbssct.gc.ca/pol/doc-eng.aspx?id=12316\$ion=HTML . Acesso em: 3 mar. 2021.

GOVERNO DIGITAL (Brasil). Estratégia de Governo Digital. Um Governo Centrado no Cidadão. Disponível em: https://www.gov.br/governodigital/pt-br/EGD2020/ centrado-no-cidadao . Acesso em: 3 mar. 2021.

GOVERNO DO BRASIL. Painel de monitoramento de serviços federais. Disponível em: https://painelservicos.servicos.gov.br . Acesso em: 28 fev. 2021.

GOV.UK. Content design: planning, writing and managing content. Disponível em: https://www.gov.uk/guidance/content-design/writing-for-gov-uk . Acesso em: $28 \mathrm{fev}$. 2021.

GOWERS, Ernest. The Complete Plain Words. Boston: David R. Godine Publisher, 1988. $288 \mathrm{p}$.

GPLS - Grupo de Pesquisadores em Linguagem Simples no Brasil. [S. l.], 23 mar. 2021. Disponível em: https://www.linkedin.com/groups/13910348/. Acesso em: 12 mar. 2021.

GRAESSER, Arthur C.; MCNAMARA, Danielle S.; LOUWERSE, Max M.; CAI, Zhiqiang. Coh-Metrix: Analysis of text on cohesion and language. Behavior Research Methods, Instruments, \& Computers, [s. l.], v. 36, n. 2, p. 193-202, 2004. Disponível em: https://www.researchgate.net/publication/8358727_Coh-Metrix_Analysis_of_text on_cohesion_and language. Acesso em: 5 mar. 2021. 
GREENE, Judith; D'OLIVEIRA, Manuela. Learning to use statistical tests in psychology. 3. ed. Maidenhead: Open University Press, 2005. 226 p. ISBN 9780335 21680.

GREGÓRIO, Alvaro. Fala, que eu te entendo. IGOVBRASIL. Julho 2011. Disponível em: http://www.igovbrasil.com/2011/07/fala-que-eu-te-entendo.html . Acesso em: 1 mar. 2021.

HAAPIO, H., \& BARTON, T. D., (2018). Business-friendly contracting : how simplification and visualization can help bring it to practice. In: Jacob, K., Schindler, D., Strathausen, R. (eds), Liquid Legal. Management for Professionals (pp. 371-396). Springer, Cham. https://doi.org/10.1007/978-3-319-45868-7 24. Disponível em:

https://core.ac.uk/download/pdf/287058536.pdf. Acesso em: 25 mar. 2021

HANSSON, Karin. Det finns ett sug efter klarspråk: En studie om bättre stöd till klarspråk i offentlig verksamhet. Stockholm: Språkrådet, 2020. Disponível em: https://www.isof.se/download/18.5711e05517292e5acd8c3121/1592211923494/Ett_sug _efter_klarsprak.pdf . Acesso em: 10 mar. 2021.

HOUAISS, Antonio. Dicionário Houaiss da Língua Portuguesa. 1ª edição. Rio de Janeiro: Objetiva, 2001.

HOUSE OF COMMONS (Parliament of the United Kingdom). Public Administration Select Committee. Bad Language: The Use and Abuse of Official Language: First Report of Session 2009-10. London: The Stationery Office Limited, 2009. 52 p. Disponível em: https://publications.parliament.uk/pa/cm200910/cmselect/cmpubadm/ 17/17.pdf . Acesso em: 2 mar. 2021.

IBGE CENSO 2010. População residente, por sexo e grupos de idade, segundo as Grandes Regiões e as Unidades da Federação - 2010. Disponível em: https://censo2010.ibge.gov.br/sinopse/index.php?dados=12 . Acesso em: 3 mar. 2021.

IBGE. PNAD Contínua - Pesquisa Nacional por Amostra de Domicílios Contínua. Educação 2019. Rio de Janeiro: IBGE, 2020. 16 p. ISBN 978-65-87201-09-2. Disponível em: https://biblioteca.ibge.gov.br/visualizacao/livros/liv101736 informativo.pdf Acesso em: 3 mar. 2021.

INEP - INSTITUTO NACIONAL DE ESTUDOS E PESQUISAS EDUCACIONAIS ANÍSIO TEIXEIRA. Relatório Brasil no Pisa 2018: Versão Preliminar. Brasilia: INEP/MEC, 2019. 158 p. Disponível em: https://download.inep.gov.br/acoes internacionais/pisa/documentos/2019/relatorio_PISA_2018 preliminar.pdf . Acesso em: 1 mar. 2021.

INSS amplia serviços remotos durante a pandemia. Notícias - Portal Gov.br. 21 mai. 2020. Disponível em: https://www.gov.br/pt-br/noticias/assistencia-social/2020/05/inssamplia-servicos-remotos-durante-pandemia. Acesso em: 4 jan. 2021.

INSS completa digitalização de todos os serviços. Notícias - Ministério da Economia. 10 jul. 2019. Disponível em: https://www.gov.br/economia/pt-br/assuntos/noticias/ 2019/07/inss-completa-digitizacao-de-todos-os-servicos . Acesso em: 28 fev. 2021. 
INTERNATIONAL PLAIN LANGUAGE FEDERATION. Plain Language definitions. Disponível em: https://www.iplfederation.org/plain-language/ . Acesso em: 2 mar. 2021.

IRISLABGOV. [(Material) - $\mathbf{1 0}$ passos para redigir textos usando a técnica da Linguagem Simples]. Link.tree. Disponível em: https://inktr.ee/irislabgov . Acesso em: 15 fev. 2021.

IRIS Laboratório de Inovação e Dados do Governo do Ceará. Webinário A experiência da Linguagem Simples no Governo do Ceará. Heloisa Fischer, Caroline Gabriel, Isabel ferreira Lima e João Ricardo Gonçalvez. 11 agosto 2020. Disponível em: https://www.youtube.com/watch?v=L1zC4aMTowk. Acesso em: 28 fev. 2021.

JAMES, Neil. Setting the standard: some steps toward a plain language profession. In: 6TH PLAIN CONFERENCE, 2007, Amsterdam. Proceedings [...]. [S. l.: s. n.], 2007. Disponível em: https:/www.plainenglishfoundation.com/documents/10191/54656/ Setting $\% 20$ the $\% 20$ Standard $\% 2 \mathrm{C} \% 20 \% 286$ th $\% 20$ PLAIN $\% 20$ Conference $\% 2 \mathrm{C} \% 20 \mathrm{Ams}$ terdam\%2C\%20October\%202007\%29.pdf . Acesso em: 3 mar. 2021.

KIMBLE, Joseph. Answering the Critics of Plain Language. The Scribes Journal of Legal Writing, Chicago, p. 51-85, 1994-1995. Disponível em: https://5f83363a-aee4$4 \mathrm{e} 75$-a59d-

83c22fd072d8.filesusr.com/ugd/3eec74_d5fe26ab73534db6b7c9baf0e8500aa9./pdf.

Acesso em: 10 mar. 2021.

KIMBLE, Joseph. Flimsy Claims for Legalese and False Criticisms of Plain Language: A 30-Year Collection. The Scribes Journal of Legal Writing, Chicago, v. 19, p. 1-14, 2020. Disponível em: https://digital.gov/pdf/pl-summit-2020-joseph-kimble.pdf . Acesso em: 10 mar. 2021.

KLEIMAN, A. Texto e leitor: aspectos cognitivos da leitura. Campinas: Pontes, 1989.

LABORATORIO DE GOBIERNO. Guia ¿Como podemos generar una comunicación simple, clara $y$ efectiva entre el Estado y la ciudadania?: Permitido Innovar. Disponível em: http://lab.gob.cl/uploads/filer_public/0e/fd/0efd74c4-6aaf-4940-a62a7e64655ec884/guia_lenguaje_claro.pdf. Acesso em: 2 mar. 2021.

LAFUENTE, Mariano; LEITE, Rafael; PORRÚA, Miguel; VALENTE, Pablo. Satisfação dos cidadãos com os serviços públicos digitais: Transformação digital dos governos brasileiros. New York: Banco Interamericano de Desenvolvimento, Março 2021. DOI http://dx.doi.org/10.18235/0003058. Disponível em: https://publications.iadb.org/pt/transformacao-digital-dos-governos-brasileirossatisfacao-dos-cidadaos-com-os-servicos-publicos . Acesso em: 17 mar. 2021.

LAW COMISSION. Report 35 - Legislation Manual/ Structure and Style. Wellington: Law Commission, 1996. Disponível em: https:/www.lawcom.govt.nz/sites/ default/files/projectAvailableFormats/NZLC\%20R35.pdf . Acesso em: 28 fev. 2021.

LIMA, Ana; CATELLI JR., Roberto (coord.). INAF Brasil 2018: Resultados preliminares. [S. l.]: Ação Educativa e Instituto Paulo Montenegro, 2018. 22 p. 
Disponível em: https://acaoeducativa.org.br/wp-content/uploads/2018/08/Inaf2018 Relat\%C3\%B3rio-Resultados-Preliminares v08Ago2018.pdf . Acesso em: 28 fev. 2021.

LIMA, Isabel F. [email]. Diretrizes de Linguagem Simples CE. Destinatária: Heloisa Fischer. 20 de maio de 2020.Enviada para heloisa@comunicasimples.com.br.

LINCLAB - Laboratório Interdisciplinar de Linguagem Cidadã. Disponível em: https://linclab.com.br/. Acesso em: 12 mar. 2021.

LINKEDIN. Grupo Plain Language Association International (PLAIN). Disponível em: https://www.linkedin.com/groups/158634/. Acesso em: 28 fev. 2021

LOPES, Karen M. Gross. Fatores direcionadores para a criação de valor público na adoção de serviços eletrônicos pelo cidadão. Dissertação (Mestrado em Administração) - Pontifícia Universidade Católica do Rio Grande do Sul, Porto Alegre, 2016. Disponível em: http://tede2.pucrs.br/tede2/bitstream/tede/7216/2/DIS_KAREN_MARIA_GROSS _LOPES_COMPLETO.pdf. Acesso em: 05 mar.2021.

LOPES, K. M.; MACADAR, M. A.; LUCIANO, E. M. Criando valor público em serviços digitais: uma proposta de conceito. Revista Eletrônica de Gestão Organizacional - GESTÃ O.ORG., v. 16, Edição especial, p. 207-221, 2018. Disponível em: https://periodicos.ufpe.br/revistas/ gestaoorg/article/view/239271/31623. Acesso em: 05 mar.2021.

LOPES, K. M.; MACADAR, M. A.; LUCIANO, E. M. Valor público: o cidadão no centro da gestão pública. In: 2017 Pesquisa TIC Governo Eletrônico. São Paulo: Comitê Gestor da Internet, 2018, p. 75-83. Disponível em https://cetic.br/media/docs/publicacoes/2/TIC_eGOV_2017_livro_eletronico.pdf. Acesso em: 05 mar.2021.

MARTINS, Stefan; FILGUEIRAS, Lucia. Métodos de Avaliação de Apreensibilidade das Informações Textuais: uma Aplicação em Sítios de Governo Electronico. In: CONGRESO LATINOAMERICANO DE LA INTERACIÓN HUMANOCOMPUTADORA 2007, 2007, Rio de Janeiro. Proceedings [...]. [S. l.: s. n.], 2007. Disponível em: https://clihc2007.laihc.org/papers/MetodosAvilacao_ID25 longpaper .pdf. Acesso em: 3 mar. 2021.

MARTINS, Teresa B.F.; NUNES, Maria das Graças Volpe; GHIRALDELO, Claudete Moreno; OLIVEIRA JUNIOR, Osvaldo Novais de. Readability formulas applied to textbooks in brazilian portuguese. Notas do ICMC, São Carlos, n. 28, Junho 1996.

MAZUR, Beth. Revisiting Plain Language: Bibliographical Essay. Technical Communication : Journal of the Society for Technical Communication, [s. l.], v. 47, n. 2, p. 205-2011, Second Quarter 2005. Disponível em: https://www.plainlanguage. gov/resources/articles/revisiting-plain-language/. Acesso em: 8 mar. 2021.

MELCHIORI, Cíntia E. Digitalização da proteção social: o desafio da inclusão. In: TIC Domicílios 2019: Pesquisa Sobre o Uso das Tecnologias de Informação e Comunicação nos Domicílios Brasileiros. São Paulo: Comitê Gestor da Internet no Brasil, 2019. 
Disponível em: $\quad \underline{\text { https://cetic.br/media/docs/publicacoes/2/20201123121817/ }}$ tic dom 2019 livro eletronico.pdf. Acesso em: 3 mar. 2021.

MENDONÇA, Neide Rodrigues de Souza. Desburocratização linguística: Como simplificar textos administrativos. São Paulo: Livraria Pioneira Editora, 1987. 80 p.

MINISTÉRIO DA CIÊNCIA, TECNOLOGIA, INOVAÇÕES E COMUNICAÇÕES (Brasil). Departamento de Políticas e Programas Setoriais em TICs. Estratégia Brasileira para a Transformação Digital: E-Digital. Brasília: Ministério da Ciência, Tecnologia, Inovações e Comunicações, 2018. 108 p. Disponível em: https://www.gov.br/mcti/pt-br/centrais-de-conteudo/comunicados-mcti/estrategiadigital-brasileira/estrategiadigital.pdf . Acesso em: 6 mar. 2021.

MINISTÉRIO DA ECONOMIA (Brasil). Secretaria de Previdência. Regime Geral RGPS: 5. Quem pode se inscrever?. Disponível em: https://www.gov.br/previdencia/ptbr/assuntos/outros/regime-geralrgps\#: : :text=S\%C3\%A3o\%20segurados\%20da\%20Previd\%C3\%AAncia\%20Social,se \%20inscrever\%20na\%20Previd\%C3\%AAncia\%20Social . Acesso em: 5 mar. 2021

MINISTÉRIO DAS COMUNICAÇÕES (Brasil). Aprova o Manual de Migração que trata da transferência do conteúdo dos portais do Governo federal para o novo Portal Institucional denominado Gov.Br. Portaria $n^{0} 484$, de 28 de agosto de 2020. Diário Oficial da União, 17 set. 2020. Disponível em: https://www.in.gov.br/web/dou/-/portarian-484-de-28-de-agosto-de-2020-277907183 . Acesso em: 5 mar. 2021

MINISTÉRIO DO PLANEJAMENTO, DESENVOLVIMENTO E GESTÃO. Estratégia de Governança Digital-EGV. Transformação digital, cidadania e governo 2016-2019: Versão revisada. Brasilia: Ministério do Planejamento, Desenvolvimento e Gestão, 2018. 56 p. Disponível em: https://www.gov.br/governodigital/pt-br/estrategia-de-governancadigital/revisaodaestrategiadegovernancadigital20162019.pdf . Acesso em: 5 mar. 2021.

MINISTER OF SUPPLY AND SERVICES (Canadá). Plain Language - Clear And Simple. Ottawa: Canada Communication Group - Publishing, 1991. 64 p. ISBN 0-66014185-X. Disponível em: http://publications.gc.ca/collections/collection_2017/ ircc/Ci53-3-3-1991-eng.pdf . Acesso em: 12 mar. 2021.

MONT'AlVÃo, Claudia. Processamento da informação (pdf). Resumo de aula no Curso de Graduação em Design da PUC-Rio, 2020.

NAÇÕES UNIDAS BRASIL. Agenda 2030 para o Desenvolvimento Sustentável. Disponível em: https://brasil.un.org/pt-br/91863-agenda-2030-para-o-desenvolvimentosustentavel. Acesso em: 28 fev. 2021.

NILC-METRIX. 9. Complexidade sintática. Disponível em: http://fw.nilc.icmc.usp.br:23380/metrixdoc. Acesso em: 22 fev. 2021

NORD, Andreas. Plain language and professional writing: A research overview. Language Council of Sweden: ISOF-The Institute for Language and Folklore, 2018. Disponível

em: 
https://www.isof.se/download/18.74fcba02165cbdce76bef271/1539952155460/Plain\%2 0language\%20and\%20professional\%20writing.pd . Acesso em: 1 mar. 2021.

NÚCLEO DE INFORMAÇÃO E COORDENAÇÃO DO PONTO BR (ed.). TIC Domicílios 2019: Pesquisa Sobre o Uso das Tecnologias de Informação e Comunicação nos Domicílios Brasileiros. São Paulo: Comitê Gestor da Internet no Brasil, 2020. 344 p. Disponível em: https://cetic.br/media/docs/publicacoes/2/20201123121817/tic dom 2019 livro_eletronico.pdf. Acesso em: 6 mar. 2021.

NÚCLEO DE INFORMAÇÃO E COORDENAÇÃO DO PONTO BR (ed.). TIC Governo eletrônico 2019: Pesquisa sobre o uso das tecnologias de informação e comunicação no setor público brasileiro. São Paulo: Comitê Gestor da Internet no Brasil, 2020. 236 p. Disponível em: https://cetic.br/media/docs/publicacoes/2/20200707094309/ tic_governo_eletronico_2019 livro_eletronico.pdf. Acesso em: 4 mar. 2021.

OCDE. Revisão do Governo Digital do Brasil - Rumo à Transformação Digital do Setor Público: Principais conclusões. [S. l.:s. n.], 2018. ISBN 9789264307636. DOI https://doi.org/10.1787/9789264307636-en. Disponível em: https://www.oecdilibrary.org/governance/digital-government-review-of-brazil 9789264307636-en Acesso em: 10 mar. 2021.

OECD. Education at a Glance - Country Note: Brazil. [S. l.: s. n.], 2019. Disponível em: https://download.inep.gov.br/acoes internacionais/eag/documentos/2019/Country Note EAG 2019 Brasil.pdf. Acesso em: 3 mar. 2021.

OFFICE OF PARLIAMENTARY COUNSEL (Austrália). Plain English Manual. $[S$. l.]: Office of Parliamentary Counsel, 1993. 41 p. Disponível em: https://www.opc.gov.au/sites/default/files/plain_english_0.pdf. Acesso em: 3 mar. 2021.

O'HAYRE, John. Gobbledygook has gotta go. Washington: U. S. Bureau of Land Management, 1966. Disponível em: https://archive.org/details/gobbledygook hasg3836ohay/page/n35/mode/2up . Acesso em: 16 fev. 2021.

ORWELL, George. Politics and the English Language. Disponível em: http://www.orwell.ru/library/essays/politics/english/e_polit/. Acesso em: 07 abr. 2021.

OUTOR, Carla. [mensagem pessoal via LinkedIn]. Destinatária: Heloisa Fischer. 23 de setembro de 2020. Enviada para https:/www.linkedin.com/in/helofischer/.

OXFORD Advanced Learner's Dictionary. Fourth Edition. Oxford: Oxford University Press, 1989.

PEDRAZA, Maria Betúlia. El lenguaje claro: metas y fallas de una política de derechos. RIUSS Journal, New York, v. 1, n. 1, 2017. Disponível em: https://riuss.org/riuss-journal-2017/el-lenguaje-claro-metas-y-fallas-de-una-politica-dederechos/. Acesso em: 28 fev. 2021.

PENMAN, Robyn. Plain English: Wrong solution to an important problem. Australian Journal of Communication, $\left[\begin{array}{ll}s . & l .\end{array}\right], \quad$ v. $19, \quad$ n. 3, 1992. Disponível em: http://stc2.uws.edu.au/pwe/Assets/week11_penman.pdf. Acesso em: 5 mar. 2021. 
PENMAN, Robyn Unspeakable Acts and other deeds: a critique of plain legal language. In: Information Design Journal 7:2 (1993), 121-131. DOI 10.1075/idj.7.2.04pen. ISSN 0142-5471 / E-ISSN 1569-979X.

PERFETTI, Charles A. Comprehending written language: a blueprint of the reader. In: BROWN, C.M.; HAGOORT, P (Eds.). The neurocognition of language. [S. l.]: Oxford University Press, 1999. p. 167-208.

PERFETTI, Charles A. Reading Skills. In: SMELSER, N.J.; BALTES, P.B. International encyclopedia of thesocial \& behavioural sciences. Oxford: Pergamon, 2001. p. 12800-12805.

PERFETTI, Charles A.; LANDI, Nicole; OAKHILL, Jane. The Acquisition of Reading Comprehension Skill. In: SNOWLING, M.J.; HULME, C. The science of reading: A handbook. Oxford: Blackwell, 2005. p. 227-247.

PETTERSSON, Rune. It Depends: Principles and guidelines. Fourth edition. ed. Wien: IIID Public Library, 2012. 212 p. ISBN 978-91-85334-24-7. Disponível em: http://www.iiid.eu/PublicLibrary/Pettersson-Rune-ID-It-Depends.pdf . Acesso em: 5 mar. 2021.

PETTERSSON, Rune. Text Design: Printed Words. Spoken Words.. Wien: IIID Public Library, 2015. 240 p. ISBN 978-91-85334-27-8. Disponível em: http://www.iiid.eu/PublicLibrary/Pettersson-Rune-ID2-Text-Design.pdf . Acesso em: 5 mar. 2021.

PLAIN LANGUAGE ACTION AND INFORMATION NETWORK. Federal Plain Language Guidelines: Improving Communications. Monce: Plain Language Action and Information Network, 2019. ISBN 9781986407700.

PLAIN LANGUAGE ASSOCIATION INTERNATIONAL (PLAIN). O que é linguagem clara?. Disponível em: https://plainlanguagenetwork.org/plain-language/oque-e-linguagem-clara/. Acesso em: 28 fev. 2021.

PLAIN LANGUAGE ASSOCIATION INTERNATIONAL (PLAIN). What is plain language?: (General areas). Disponível em: https://plainlanguagenetwork.org/plainlanguage/what-is-plain-language/ . Acesso em: 28 fev. 2021.

PLAIN LANGUAGE ASSOCIATION INTERNATIONAL. Who we are. Disponível em: https://plainlanguagenetwork.org/plain/who-we-are/. Acesso em: 28 fev. 2021

PLAINLANGUAGE.GOV. Federal Plain Language Guidelines. Disponível em: https://www.plainlanguage.gov/guidelines . Acesso em: 28 fev. 2021.

PLAIN. Oxford Advanced Learner's Dictionary. Oxford: Osford University Press, 1989

PODER JUDICIAL (Peru). Manual judicial de lenguaje claro y accesible a los ciudadanos. Lima: Poder Judicial, Diciembre 2014. 43 p. Disponível em: 
https://www.pj.gob.pe/wps/wcm/connect/7b17ec0047a0dbf6ba8abfd87f5ca43e/MANU AL+JUDICIAL+DE+LENGUAJE+CLARO+Y+ACCESIBLE.pdf?MOD=AJPERES . Acesso em: 3 mar. 2021.

PODER JUDICIÁRIO (Brasil). Conselho Nacional de Justiça. Justiça em Números 2020: Ano-base 2019. Brasília: CNJ, 2020. 267 p. Disponível em: https://www.cnj.jus.br/wp-content/uploads/2020/08/WEB-V3-Justi\%C3\%A7a-emN\%C3\%BAmeros-2020-atualizado-em-25-08-2020.pdf . Acesso em: 11 mar. 2021.

PREFEITURA lança Programa Municipal de Linguagem Simples. Notícias - Cidade de São Paulo. 12 nov. 2019. Disponível em: http://www.capital.sp.gov.br/noticia/prefeituralanca-programa-municipal-de-linguagem-simples . Acesso em: 28 fev. 2021.

PRESIDÊNCIA DA REPÚBLICA (Brasil). Casa Civil. Manual de redação da Presidência da República. 3. ed. rev. atual. e aum. Brasília: Presidência da República, 2018. 189 p. Disponível em: http://www4.planalto.gov.br/centrodeestudos/assuntos/ manual-de-redacao-da-presidencia-da-republica/manual-de-redacao.pdf . Acesso em: 16 mar. 2021.

PROGRAMA DE GOVERNO ELETRÔNICO BRASILEIRO. EMAG - Modelo de Acessibilidade em Governo Eletrônico. $[S$. l.], Abril 2014. Disponível em: http://emag.governoeletronico.gov.br . Acesso em: 4 mar. 2021.

PROGRAMA MUNICIPAL DE LINGUAGEM SIMPLES. Metodologia Linguagem Simples: 10 dicas para escrever em linguagem simples: Ferramentas de apoio. Disponível em: https://011lab.prefeitura.sp.gov.br/linguagem-simples/ferramentas-deapoio. Acesso em: 28 fev. 2021.

PROJETO para instituir Política Municipal de Linguagem Simples é aprovado. A Cidade On. 8 dez. 2020. Disponível em: https://www.acidadeon.com/saocarlos/politica/ NOT, 0,0,1566650,projeto-para-instituir-politica-municipal-de-linguagem-simples-eaprovado.aspx . Acesso em: 28 fev. 2021. Acesso em: 28 fev. 2021.

RAMOS, Arthur; LACANNA, Santino; LONGA, Emmanuel; VIANA, Luis Daniel; PAGAN, Lucas Consales; SOARES, Mariana; VAZ, Rodrigo; MATOS, Bruna. Qual é o impacto que a transformação digital pode ter para a previdência social?. São Paulo: BrazilLAB, Fundação BRAVA e Centre for Public Impact, Julho 2019. Disponível em: https://previdenciadigital.brazillab.org.br/ . Acesso em: 19 fev. 2021.

RATNER, Nan Bernstein Ratner. GLEASON, Jean Berko. Psycholinguistics Reference Module in Neuroscience and Biobehavioral. Encyclopedia of Neuroscience. S/1: Academic Press, 2004. Pages 1199-1204.

READABILITY. In: WordNet, A Lexical Database for English. Princeton: Princeton University. Disponível em: http://wordnetweb.princeton.edu/perl/webwn?s= readability \&sub $=$ Search + WordNet\&o $2=\& 00=1 \& 08=1 \& 01=1 \& 07=\& 05=\& 09=\& 06=\&$ $\mathrm{o} 3=\& \mathrm{o} 4=\& \mathrm{~h}=$. Acesso em: 22 fev. 2021.

RED DE LENGUAJE CLARO ARGEnTINA. Qué es la Red. Disponível em: http://lenguajeclaroargentina.gob.ar/conoce/ . Acesso em: 9 mar. 2021. 
RED DE LENGUAJE CLARO CHILE. Acuerdo de colaboración entre Excelentísima Corte Suprema de Chile, la Honorable Cámara de Diputados de Chile, la Contraloría General de la República, el Consejo para la Transparencia, la Pontificia Universidad Católica de Valparaíso y la Biblioteca del Congreso Nacional. Santiago: Red de Lenguaje Claro Chile, Março 2017. v. 4. Disponível em: http://www.lenguajeclarochile.cl/wp-content/uploads/2018/03/ACUERDO $\%$

20DE\%20COLABORACIO \%CC\%81N\%20RED\%20L\%20C.pdf . Acesso em: 3 mar. 2021.

RODRIGUES, Giovana de Sousa. Um corretor terminológico para a lei: substituindo termos incomuns por termos familiares ao cidadão. Congresso Nacional Universidade EAD e Software Livre - UEADSL, [s. l.], v. 1, n. 4, 2013. Disponível em: http://www.periodicos.letras.ufmg.br/index.php/ueadsl/article/view/4827 . Acesso em: 3 mar. 2021.

ROSETH, Benjamin; REYES, Angela; SANTISO, Carlos. O fim dos trâmites eternos - Resumo Executivo: Cidadãos, burocracia e governo digital. Washington: Banco Interamericano de Desenvolvimento, 2018. 19 p. Disponível em: https://publications.iadb.org/publications/portuguese/document/O-fim-dos-tr\%C3\%A2 mites-eternos-Cidad\%C3\%A3os-burocracia-e-governo-digital-(Sum\%C3\%A1rioexecutivo).pdf. Acesso em: 4 mar. 2021.

ROSETH, Benjamin; REYES, Angela; SANTISO, Carlos. Wait no more: Citizens, red tape, and digital government. Washington: Inter-American Development Bank, 2018. ISBN 978-1-59782-335-7. DOI http://dx.doi.org/10.18235/0001150. Disponível em: https://publications.iadb.org/en/wait-no-more-citizens-red-tape-and-digital-government . Acesso em: 3 mar. 2021.

RUDNICKA, Karolina. Variation of sentence length across time and genre. In: WHITT, Richard Jason (ed.). Diachronic Corpora, Genre, and Language Change [Studies in Corpus Linguistics 85]. Amsterdam \& Philadelphia: John Benjamins, 2018. p. 220-240. Disponível em: https://www.academia.edu/39048052/Variation_of_sentence_length across time and genre influence on the syntactic usage in_English $\overline{\bar{h}}$. Acesso em: 3 mar. 2021.

SÃO PAULO (MUNICÍPIO). Decreto no 59.067, de 11 de novembro de 2019. Institui o Programa Municipal de Linguagem Simples no âmbito da Administração Pública Municipal. Disponível em: http://legislacao.prefeitura.sp.gov.br/leis/decreto-59067-de11-de-novembro-de-2019 . Acesso em: 9 mar. 2021.

SÃO PAULO (MUNICÍPIO). Lei n⿳ 17.316, de 6 de março de 2020. Institui a Política Municipal de Linguagem Simples nos órgãos da administração direta e indireta. Disponível em: https://leismunicipais.com.br/a/sp/s/sao-paulo/lei-ordinaria/2020/ 1732/17316/lei-ordinaria-n-17316-2020-institui-a-politica-municipal-de-linguagemsimples-nos-orgaos-da-administracao-direta-e-indireta . Acesso em: 6 mar. 2021.

SCARTON, C. E.; ALUÍSIO, S. M. Análise da Inteligibilidade de textos via ferramentas de Processamento de Língua Natural: adaptando as métricas do Coh -Metrix para o Português. LinguaMÁTICA, v. 2 , n.1, Abril 2010, p. 45-62. 
SCHRIVER, Karen A. Dynamics in document design. New York: John Wiley \& Sons, Inc., 1997. 562 p.

SCHRIVER, Karen. On developing plain language principles and guidelines. In: HALLIK, Katrin; WHITESIDE, Kate Harrison (ed.). Clear communication: A brief overview. Tallinn, Estonia: Institute of the Estonian Language: Foundation of the Estonian Language, October 2014. cap. 6, p. 55-69. Disponível em: https://www.researchgate.net/publication/282735182 On_developing_plain_language principles_and guidelines. Acesso em: 1 mar. 2021.

SCHRIVER, Karen A. Plain Language in the US Gains Momentum: 1940-2015. IEEE Transactions on Professional Communication, [s. l.], v. 60, n. 4, December 2017. DOI 10.1109/TPC.2017.2765118. Disponível em: https://ieeexplore.ieee.org/ document/8115322 . Acesso em: 2 mar. 2021.

SCHRIVER, Karen; GORDON, Frances. Grounding plain language in research. Clarity,

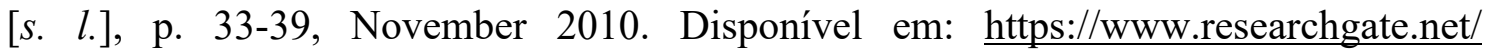
profile/Karen-Schriver/publication/276919581

Grounding_plain_language_in_research/links/555b884308ae91e75e76648e/Groundingplain-language-in-research.pdf . Acesso em: 2 mar. 2021.

SECRETARIA DE LA FUNCIÓN PÚBLICA (México). Lenguaje Ciudadano: Un manual para quien escribe en la Administración Pública Federal. México, DF: Secretaría de la Función Pública, 2004. 80 p. ISBN 970-653-080-0. Disponível em: http://www.gobernacion.gob.mx/work/models/SEGOB/Resource/148/1/images/Manual lenguaje ciudadano.pdf. Acesso em: 5 mar. 2021.

SEMANA DE INOVAÇÃO 2020. Linguagem Simples mão na massa!: Oficina. [S. l.], 17 nov. 2020. Disponível em: https://semanadeinovacao.enap.gov.br/programacao/ resultados?busca=linguagem + simples . Acesso em: 8 mar. 2021.

SHUMSKAYA, Daria. Linguagem Clara: uma questão de cidadania corporativa para as instituições financeiras?. Orientador: Prof. ${ }^{a}$ Doutora Mafalda Eiró-Gomes. 2019. 104 p. Dissertação (Mestrado em Gestão Estratégica das Relações Públicas) Escola Superior de Comunicação Social do Instituto Politécnico de Lisboa, Lisboa, 2019. Disponível em: https://repositorio.ipl.pt/handle/10400.21/11375. Acesso em: 9 mar. 2021.

SILVEIRA, Maria Inez Matoso. O burocratês: análise à luz de uma gramática retórica. Revista da ABRALIN, [s. l.], v. 7, n. 1, p. 215-258, jan./jun. 2008. Disponível em: https://revista.abralin.org/index.php/abralin/article/view/985 . Acesso em: 5 mar. 2021.

STARCK, Stark. Plain Language. In: The Legislative Lawyer. June 1992. Disponivel em: https://www.ncsl.org/legislators-staff/legislative-staff/research-editorial-legal-andcommittee-staff/june-2012-plain-language.aspx . Acesso em: 22 fev. 2021

TAKAHASHI, Tadao (org.). Sociedade da Informação no Brasil: Livro Verde. Brasilia: Ministério da Ciência e Tecnologia, Setembro 2000. 95 p. ISBN 85-88063-018. Disponível em: https://livroaberto.ibict.br/handle/1/434 . Acesso em: 28 fev. 2021. 
TAMURA, Gabriela. Vamos parar de falar "governês"?. In: Blog WeGov. [S. l.], 9 jun. 2016. Disponível em: https://wegov.net.br/voce-fala-governes/ . Acesso em: 5 mar. 2021

THE CITY OF CALGARY. Plain Language Policy. 2013 May 27. Disponível em: https://www.calgary.ca/CA/city-clerks/Documents/Council-policy-library/CS014-PlainLanguage-Policy.pdf . Acesso em: 28 fev. 2021

TURFLER, Soha. Language Ideology and the Plain-Language Movement: How StraightTalkers Sell Linguistic Myths. Legal Communication \& Rhetoric: JALWD, [s. l.], v. 12, p. 195-218, 2015. Disponível em: https://papers.ssrn.com/sol3/papers.cfm? abstract_id=2679724. Acesso em: 9 mar. 2021.

UNITED NATIONS. E-Government Survey 2018: Gearing E-Government To Support Transformation Towards Sustainable And Resilient Societies. New York: United Nations, 2018. 300 p. ISBN 978-92-1-047227-2. Disponível em: https://publicadministration.un.org/egovkb/en-us/Reports/UN-E-Government-Survey2018. Acesso em: 28 fev. 2021.

UNITED NATIONS. E-Government Survey 2020: Digital Government in the Decade of Action for Sustainable Development. New York: United Nations, 2020. 364 p. ISBN 978-92-1-005145-3. Disponível em: https://publicadministration.un.org/egovkb/enus/Reports/UN-E-Government-Survey-2020 . Acesso em: 4 mar. 2021.

UNITED STATES OF AMERICA - 77 th CONGRESS. Public Law $\mathbf{n}^{\mathbf{0}} \mathbf{8 3 1}$, de 24 de dezembro de 1942. Federal Reports Act of 1942. An Act To coordinate Federal reporting services, to eliminate duplication and reduce the cost of such services, and to minimize the burdens of furnishing information to Federal agencies. Washington, 24 dez. 1942. Disponível em: https://www.loc.gov/law/help/statutes-at-large/77th-congress/session2/c77s2ch811.pdf. Acesso em: 9 mar. 2021.

UNITED STATES OF AMERICA - $111^{\text {th }}$. CONGRESS. Public Law no 111-274, de 13 de outubro de 2010. Plain Writing Act of 2010. Washington, 13 out. 2010. Disponível em: https://www.govinfo.gov/content/pkg/PLAW-111publ274/pdf/PLAW-111publ274 .pdf . Acesso em: 3 mar. 2021.

VAN DIJK, T.A. Cognição, discurso e interação. São Paulo: Contexto, 1992.

VILJOEN, Frans. Baring the nation's soul through plain language. Clarity, [s. l.], v. 46, July 2001. Disponível em: https://constitutionnet.org/sites/default/files/Viljoen $\% 20 \mathrm{~F} . \% 20 \% 20$ Baring\% $\% 20$ the $\% 20$ Nations $\% 20$ Soul $\% 20$ through $\% 20$ Plain $\% 20$ Languag e.pdf. Acesso em: 2 mar. 2021.

WALLER, Rob. Technical paper 14: Information design: how the disciplines work together. Simplification Center: [s. n.], August 1995, reprinted March 2011. Disponível em: https://www.simplificationcentre.org.uk/resources/technical-papers. Acesso em: 4 mar. 2021.

WEBINÁRIO Linguagem Simples e Poder Público. 11 maio 2020. Online. Facebook da Escola do Parlamento da Câmara Municipal de São Paulo. Com Daniel Annenberg, 
Heloisa Fischer, Eduardo Tuma e Maria Nazareth Lins Barbosa. Disponível em: https://www.facebook.com/watch/?v=2564551893856535 . Acesso em: 28 fev. 2021.

WEBSTER'S New World Dictionary. Third College Edition. Cleveland \& New York: Simon \& Schuster, 1988.

WILLERTON, Russell. Plain Language and Ethical Action: A Dialogic Approach to Technical Content in the 21st Century. New York: Routledge, 2015. DOI https://doi.org/10.4324/9781315796956. Disponível em: https://www.taylorfrancis .com/books/plain-language-ethical-action-russell-willerton/10.4324/9781315796956 . Acesso em: 8 mar. 2021.

WILLIAMS, Christopher. Changing with the Times: The Evolution of Plain Language in the Legal Sphere. Alicante Journal of English Studies, [s. l.], v. 25, p. 183-203, December 2015. DOI 10.14198/raei.2015.28.10. Disponível em: https://www.researchgate.net/publication/304231720_Changing_with_the_Times_The Evolution_of_Plain_Language_in_the_Legal_Sphere. Acesso em: 9 mar. 2021.

ZANDER, Michael. The law-making process. 7. ed. Oxford: Hart Publishing, 2015. 


\section{Apêndice 1}

Como foram atribuídas as $\mathbf{5 6}$ palavras-chave às diretrizes governamentais de Linguagem Simples

\section{Siglas, palavras-chaves e respectivas áreas de concentração}

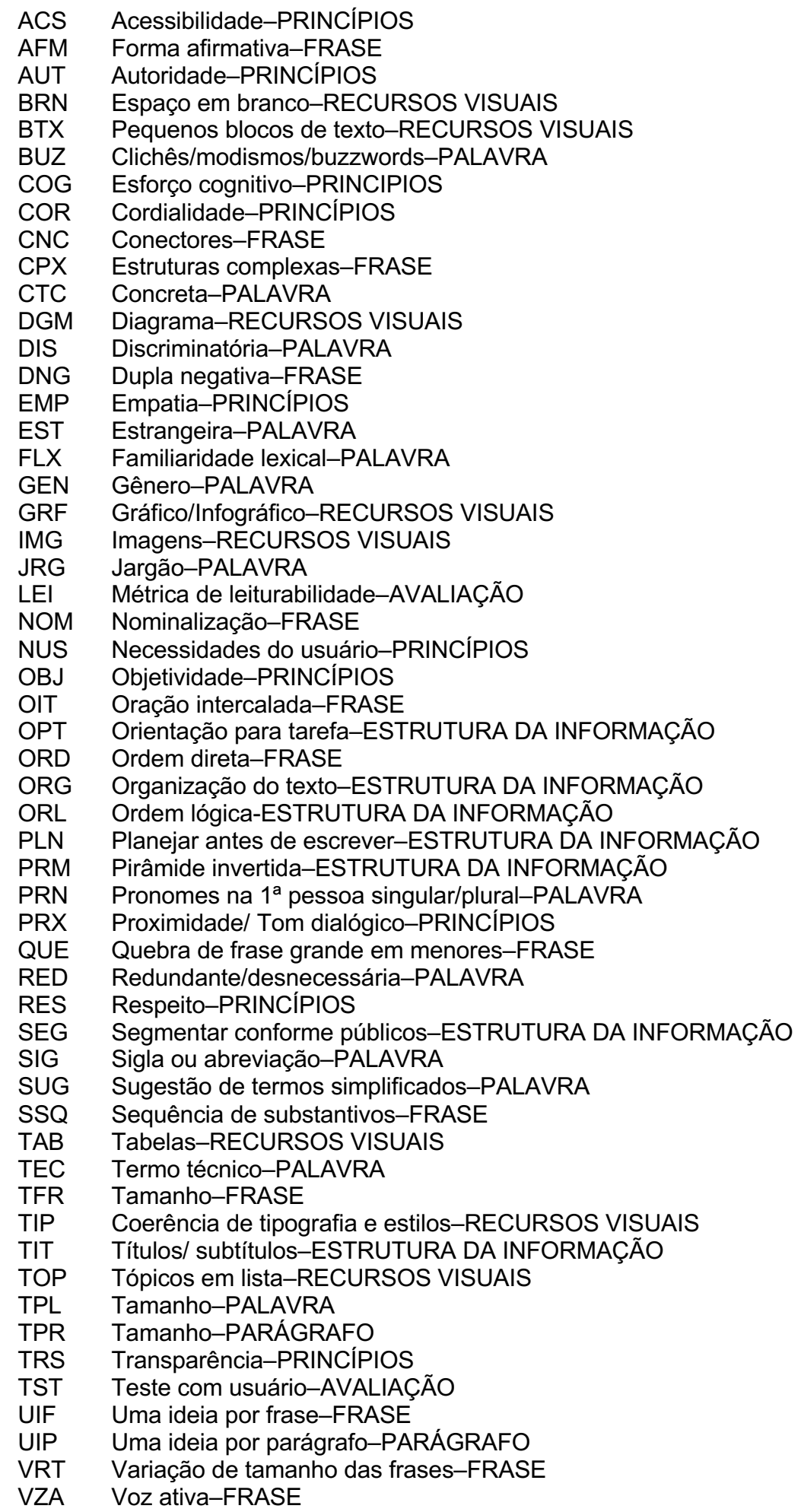




\section{Governos de língua inglesa e suas diretrizes}

\section{Austrália}

- $\quad$ Evite jargões para que o usuário entenda o conteúdo na primeira leitura. JRG Avoid jargon so the user can understand the content the first time they read it.

- Use voz ativa (sujeito-verbo-objeto). Use primeira e segunda pessoas (nós, nosso) em vez de terceira pessoa (ele, ela, eles). A voz ativa vai direto ao ponto. Evite voz passiva (objeto-verbo-sujeito). Você pode usar a voz passiva se não conseguir especificar quem fez a ação. Use contrações. VZA; PRN; OBJ

Use active voice (subject-verb-object). Use first and second person (we, us) instead of third person (he, she, it, they). Active voice gets straight to the point. Avoid passive voice (object-verb-subject). You can use the passive voice if you can't specify the do-er of the action. Use contractions.

- Use as palavras, termos, frases e parágrafos mais curtos e simples, em vez dos mais longos. TPL; TFR; TPR

Use the shorter, plain English word, term, sentence and paragraph over the longer.

- Minimize a pontuação. Use várias frases curtas em vez de uma frase longa separada por pontuação. QUE

Minimise punctuation. Use several short sentences instead of a long sentence broken up with punctuation.

- Escreva para o nível de leitura de uma criança de 9 anos. Use as ferramentas de legibilidade com cuidado. Não teste só o nível de leitura. LEI, TST, ACS(wcag), WEB, COG

Aim for an age 9 reading level. Use readability tools with care. Don't just test reading level.

- $\quad$ Certifique-se que todos os usuários entenderão. FLX, NUS, ACS, EMP

Make sure all of the users can understand.

- Lista de palavras e termos em Linguagem Simples (Não escreva assim/ Escreva assim) SUG

Plain English words and terms (Don't write this/ Write this).

\section{Canadá}

- $\quad$ Comece com as informações mais importantes. PRM, OBJ, WEB, RED, OPT

Start with the most important information.

- Use palavras simples e comuns. FLX, WEB, EMP, TPL

Use simple and common words.

- Use voz ativa e forma afirmativa. VZA, AFM, DNG Use active voice and positive form.

- Use verbos em vez de substantivos formados a partir de verbos. NOM Use verbs instead of nouns formed from verbs.

- $\quad$ Evite jargões, expressões idiomáticas e sentido figurado. JRG, TEC Avoid jargon, idioms and expressions.

- $\quad$ Use frases simples. ORD, SSQ, WEB, CPX, VRT Use simple sentences.

- Use frases e parágrafos curtos. TFR (20/24), TPR (3 frases), RED, WEB, ACS, UIF, UIP, TOP, OPT, QUE

Use short sentences and paragraphs. 
- $\quad$ Explique referências à legislação. OPT

Explain references to legislation.

- Verifique o nível de leitura do conteúdo. LEI, TST, TOP, OPT, NUS

Check the reading level of the content.

\section{Estados Unidos}

- Escreva para o seu público. Faça pesquisa. Dirija-se ao usuário. Use substantivos e verbos no singular. Dirija-se separadamente a públicos distintos. SEG, NUS, FLX, EMP, OPT, PRN, ORL, TST, PRX, PLN

Write for your audience. Do your research. Address the user. Use singular nouns and verbs. Address separate audiences separately.

- Organize as informações. Deixe-as fáceis de acompanhar. Adicione títulos úteis. Coloque uma frase que resume o tema. Ponha a idéia principal antes de exceções e condições. Use palavras de transição. Use listas.

ORG, OPT, ORL, TIT, TOP, PRM, OBJ Organize the information. Make it easy to follow. Add useful headings. Have a topic sentence. Place the main idea before exceptions and conditions. Use transition words. Use lists.

- $\quad$ Escolha cuidadosamente as suas palavras. Use palavras e frases simples (LISTA DE PALAVRAS PARA EVITAR). Evite verbos ocultos. Evite substantivos enfileirados. Evite o jargão. Use um mínimo de abreviações. Use um mínimo de definições. Use os mesmos termos de forma consistente. Posicione as palavras com cuidado. JRG, TEC, SIG, FLX, CTC, SUG, NOM, SSQ, BUZ, OBJ, CPX

Choose your words carefully. Use simple words and phrases (LIST OF WORDS TO AVOID). Avoid hidden verbs. Avoid noun strings. Avoid jargon. Minimize abbreviations. Minimize definitions. Use the same terms consistently. Place words carefully.

- Seja conciso. Escreva frases curtas. Mantenha próximos sujeito, verbo e objeto. Use linguagem afirmativa. Escreva parágrafos curtos. Escreva seções curtas. RED, PRX, TFR (1 ideia por frase), TPR (1 tópico, 3-8 frases, 150-250 palavras, ok uma frase só), UIP, UIF, OIT, ORD, AFM, DNG, BRN, TIT, WEB, QUE

Be concise. Write short sentences. Keep the subject, verb, and object close together. Use positive language. Write short paragraphs. Write short sections.

- Mantenha um tom de conversa. Use a voz ativa. Use o tempo presente. Use contrações. Dê exemplos. Use "deve" para indicar requisitos. Não use barras. VZA, PRX Keep it conversational. Use active voice. Use the present tense. Use contractions. Use examples. Use "must" to indicate requirements. Don't use slashes.

- Diagrame para a leitura. Use tabelas para facilitar a compreensão de materiais complexos. Considere o uso de elementos visuais. Destaque conceitos importantes. Use um mínimo de referências cruzadas. BTX, IMG, TIT, TOP, TFR, TIP, TAB, WEB, EST Design for reading. Use tables to make complex material easier to understand. Consider using visuals. Highlight important concepts. Minimize cross-references.

- $\quad$ Siga os padrões da web. Evite FAQs. Escreva links efetivos. Reescreva material impresso para a web. Evite a sobrecarga de PDF. WEB, OPT, PRM, RED, TIT, TOP, TAB, ACS, ORL, BTX

Follow web standards. Avoid FAQs. Write effective links. Repurpose print material for the web. Avoid PDF overload.

- Teste suas suposições. Teste de paráfrase. Teste de usabilidade. Estudos comparativos controlados. TST

Test your assumptions. Paraphrase testing. Usability testing. Controlled comparative studies.

\section{Nova Zelândia}

- $\quad$ Escolha palavras fáceis e curtas, não formais, longas. FLX, TPL, WEB, ACS(wcag)

Choose easy and short words not formal, long ones. 
- Jargão e buzzwords dificilmente serão uma linguagem clara. JRG, BUZ, OBJ, TRS Jargon and buzzwords are unlikely to be clear language.

- Escreva num tom de conversa, em primeira pessoa, usando a voz ativa. PRX, AUT, VZA, PRN

Write conversationally, in first person, using the active voice.

- Teste seu conteúdo com usuários. TST

Test your content with users.

- $\quad$ Deixe sua frase com uma média de 15 palavras. TFR (25mx, 15 md), TOP, VRT, QUE Make your average sentence 15 words long.

- $\quad$ Evite estruturas complexas de sentenças. CPX, COG Avoid complex sentence structures.

- Ferramentas de teste de leiturabilidade: Readability Calculator at Online-Utility.org, Readability Test Tool, Hemingway. LEI Readability testing tools: Readability Calculator at Online-Utility.org, Readability Test Tool, Hemingway.

\section{Reino Unido}

- $\quad$ Lista de palavras a evitar. SUG

List of words to avoid.

- $\quad$ Não use palavras formais ou longas quando as fáceis ou curtas bastarem. Use 'comprar' em vez de 'adquirir', 'ajudar' em vez de 'assistir', e 'cerca de' em vez de 'aproximadamente'. TPL, FLX

Do not use formal or long words when easy or short ones will do. Use 'buy' instead of 'purchase', 'help' instead of 'assist', and 'about' instead of 'approximately'.

- Perdemos a confiança das pessoas ao escrevermos 'buzzwords' e jargões governamentais. Muitas vezes, essas palavras são genéricas e vagas e podem levar a interpretações erradas ou a textos vazios e sem sentido. Podemos dispensá-las.BUZ, JRG

We also lose trust from people if we write government 'buzzwords' and jargon. Often, these words are too general and vague and can lead to misinterpretation or empty, meaningless text. We can do without these words.

- Em geral, você pode se livrar de todas essas palavras, trocando-as pela descrição do que está fazendo de fato. Seja franco e específico. OBJ, TRS

With all of these words you can generally get rid of them by breaking the term into what you're actually doing. Be open and specific.

- Escreva em tom de conversa - imagine o seu público e escreva como se estivesse falando com ele individualmente, mas com a autoridade de alguém que pode ajudar efetivamente. CNV, PRX, AUT

Write conversationally - picture your audience and write as if you were talking to them one-to-one but with the authority of someone who can actively help.

\section{Governos de língua espanhola e suas diretrizes}

\section{Chile}

- Usam-se frases curtas. TFR

Se utilizan frases cortas.

- $\quad$ Evitam-se frases intermediárias que geralmente aparecem entre vírgulas ou hífens. OIT Se evitan frases intermedias que regularmente aparecen entre comas o guiones. 
- Evita-se o uso de palavras difíceis de entendimento difícil para uma pessoa sem relação com a instituição. FLX

Se evita el uso de palabras de difícil comprensión para una persona que no está relacionada con la institución.

- Deixam-se fora os tecnicismos. No lugar deles, incorpora-se uma descrição breve e simples do que se quer dizer com eles. TEC, OBJ

Se dejan fuera los tecnicismos. En su reemplazo se incorporan una descripción breve y simple de lo que se quiere dar a entender con ellos.

- $\quad$ Escreve-se diretamente às pessoas usando o pronome "tu" ou "você", para que elas sejam o sujeito da oração. PRN

Se redacta directamente a las personas utilizando el pronombre "tu" o "usted", de modo que éstas sean el sujeto de toda oración.

- Eliminam-se palavras desnecessárias ou que não agreguem informações adicionais (tais como: geralmente, diretamente, felizmente, ou outras, caso a caso). RED

Se eliminan palabras innecesarias o que no aportan información adicional (tales como: generalmente, directamente, afortunadamente u otras según cada caso).

- Usam-se frases afirmativas.

AFM

Se usan frases afirmativas.

- Dá-se preferência a listas em vez de grandes parágrafos de informação.TOP Se privilegia el uso de listados antes que grandes párrafos de información.

\section{Colômbia}

- Coloque-se no lugar do cidadão. Considere o que a pessoa sabe, o que ela precisa saber, e o resultado que você quer alcançar. EMP, NUS, TRS, OPT, TEC, SIG, ACS, RES, COR, WEB, PRX, FLX

Póngase en los zapatos del ciudadano. Tenga en cuenta lo que la persona sabe, lo que necesita saber y el resultado que desea obtener.

- Faça uma lista das ideias que você quer transmitir em ordem lógica e planeje a sequência. PLN, ORL RED, CLZ, OPT

Haga una lista de las ideias que quiere transmitir en orden lógico y planee el recorrido.

- $\quad$ Organize o texto em etapas. Toda comunicação deve ter um cabeçalho indicando o assunto ou referência, ou seja, a finalidade do documento. TIT, PLN, VER, OPT, TIP, ORG

Organice el texto por pasos. Toda comunicación debe tener un encabezado que indique el asunto o referencia, es decir, el propósito del documento.

- As frases devem ser curtas. Não mais de 20 palavras (memória de curto prazo não retém mais, quando se chega ao fim, não se lembra do início). TFR (20), TPR (3 frases, 5 linhas), UIF, UIP, TOP, QUE, ORL, VER

Las frases deben ser cortas. No más de 20 palabras (la memoria a corto plazo no retiene más, cuando se llega al final, no se recuerda el principio).

- Use uma linguagem que seja próxima. Fale na primeira pessoa. Comunicações governamentais são uma oportunidade para gerar proximidade com o cidadão. FLX, PRN, PRX, NOM, VZA, RED, REV, CPX

Use un lenguaje cercano. Hable en primeira persona. Las comunicaciones del Estado son una oportunidad para generar cercania com el cuidadano.

- Evite os jargão legal, as duplas negações e o tom imperativo. Use linguagem simples, direta e humana. JRG, DNG, TEC, AFM, SUG, VZA, OBJ, OPT

Evite los legalismos, las dobles negaciones y el tono imperativo. Use lenguaje simple, directo y humano.

- Evite a solenidade. Reiterando a importância da linguagem para aproximar os cidadãos do Estado. PRX, NUS

Evite la solemnidad. Reiterando la importancia de que el lenguaje debe acercar al 
ciudadano al Estado

- Não abuse de siglas, por mais óbvias que lhe pareçam. SIG, REF

No abuse de las siglas por obvias que a usted le parezcan.

- Pense em imagens. Use auxílios visuais para indicar o que for mais relevante. TIP, IMG, GRF, DGM, BTX, CTT, BRN, TAB, COG

Piense en imágenes. Use ayudas visuales para indicar lo más relevante.

- Revise. Revise... E depois teste. TST, CLZ

Revíselo. Revíselo... Y luego póngalo a prueba.

\section{Governos de língua portuguesa e suas diretrizes}

\section{Portugal}

- Pensar no público-alvo - O principal elemento para comunicar uma mensagem em linguagem simples consiste em pensar no público a que se destina. É importante conhecer as características do destinatário para identificar, entre outros aspetos, quais são seus interesses, necessidades, expectativas e nível de conhecimento. NUS, EMP

- Usar a estrutura básica de um texto - A estrutura básica para organizar documento contém três pontos: Introdução - Dá ao leitor o contexto global necessário e responde a perguntas como:O que é este documento? Qual é o seu propósito? O que isso tem a ver com o leitor? Por que é importante? Como é organizado? Corpo - Neste ponto, desenvolve-se as respostas às perguntas do leitor identificadas no ponto anterior. Conclusão - As ideias centrais são retomadas e concluídas com uma ideia final, ou seja, explica-se ao leitor o que fazer a seguir. PLN, ORG

- Usar títulos e subtítulos - $\mathrm{O}$ uso de títulos ou subtítulos indica como está estruturado o texto. O uso de títulos ajuda a entender melhor o seu conteúdo. Deve-se destacar as informações mais importantes no documento através dos títulos. TIT

- Usar palavras simples - $\mathrm{O}$ uso de palavras complexas deixa o leitor desconfortável. $\mathrm{O}$ uso de palavras simples numa comunicação não reduz a qualidade da escrita, mas sim ganha-se a credibilidade e a confiança do leitor. Deve-se dar preferência ao uso das palavras mais simples e familiares. Quando se usa termos técnicos deve-se explicar ou definir o termo para que se possa compreender. Deve-se evitar colocar siglas sem o seu significado. FLX, TEC, SIG

- Usar frases curtas - As frases longas são mais difíceis de ler, geralmente contém várias ideias e quando o leitor é confrontado com várias ideias, corre o risco de se perder. Numa frase recomenda-se a utilização de 20 a 30 palavras. TFR

- Separar as informações em parágrafos curtos - Um parágrafo longo dá a sensação de que o documento é difícil de entender, enquanto que o uso de parágrafos curtos facilita o entendimento e permite dividir a informação. Para a separação de um parágrafo, recomenda-se o uso de cabeçalhos informativos. TPR, TIT

- Evitar o uso de palavras desnecessárias - Um bom texto contém apenas as palavras necessárias para transmitir a mensagem. Deve-se pensar em se todas as palavras fornecem informações relevantes para o leitor ou se poderia dizer-se o mesmo com menos palavras. RED

- Usar a voz ativa - A voz ativa indica que o sujeito é o agente da ação verbal. Numa frase possui a característica de envolver o leitor na ação, capta a atenção do sujeito, que deve executar a ação e requer menos palavras. VZA

- Usar auxiliares visuais - $\mathrm{O}$ uso de elementos visuais, ajuda na leitura do documento, facilitando rapidamente a localização das informações. $O$ uso recursos visuais torna 0 texto mais interessante para leitor. Pode usar os seguintes elementos: Lista com 
marcadores, Tabelas, Fluxogramas, Diagramas. TOP, TAB, DEM

\section{Brasil (Portal GOV.BR)}

- Palavras longas - Palavras longas, com mais de 4 sílabas, exigem um esforço extra de concentração. Substitua por palavras curtas, se possível. TPL

- Palavras difíceis - O uso de palavras difíceis pode gerar mal-entendidos. Substitua por palavras conhecidas pelo público-alvo do texto. FLX

- Palavras estrangeiras - Muitas pessoas não sabem o significado de palavras em outras língua. Substitua por palavras em português. EST

- Abreviaturas - O uso de abreviaturas pode comprometer a compreensão do texto. Use a palavra por extenso ou apenas abreviaturas conhecidas. SIG

- Siglas - O significado das siglas pode mudar, dependendo do contexto e da situação em que são empregadas. Explique o significado da sigla na primeira vez em que ela aparecer no texto. SIG

- Jargões - O uso de palavras, expressões ou frases comuns em grupos sociais, culturais ou profissionais específicos pode dificultar o entendimento de determinados conceitos por parte da maioria das pessoas. Substitua por palavras, expressões ou frases conhecidas pelo público-alvo do texto. JAR, FLX

- Termos Técnicos - O uso de termos técnicos específicos de determinadas atividades profissionais pode dificultar o entendimento do texto. TEC

- Termos sexistas, pejorativos ou discriminatórios - O uso de palavras somente no masculino reafirma e torna comum a ideia de superioridade do homem em relação a mulher. O uso de termos pejorativos ou discriminatórios reafirma estereótipos e preconceitos por meio da linguagem escrita. Substitua por palavras neutras. Utilize as palavras nos dois gêneros. Flexione as palavras femininas. DIS, GEN

- Substantivos que indicam ação - Verbos expressam a ação que deve ser feita de forma mais clara que substantivos. Substitua substantivos por verbos de ação. NOM

- Substantivos abstratos - Substantivos abstratos, que designam conceitos, estados e sentimentos, são de difícil compreensão. Substitua por palavras concretas que designam objetos, pessoas, ações ou lugares. CTC

- Frases na voz passiva - Na voz passiva, o sujeito sofre ou recebe uma ação do verbo. Reescreva a frase na voz ativa. VZA

- Frases na ordem indireta - Frases na ordem indireta ou com intercalações podem dificultar a identificação do autor da ação. Reescreva a frase na ordem direta: Sujeito > Verbo > Predicado. ORD

- Frases com mais de 20 palavras - Frases longas dificultam o entendimento e a concentração. Divida em mais frases. TFR, QUE

\section{Ceará}

- Planejar, redigir e entregar ao (à) cidadão (a) textos com informações claras e compreensíveis. PLN

- Usar sempre tom cordial e respeitoso. COR, RES

- Dividir textos em parágrafos curtos usando, quando necessário, marcadores de tópicos para separar informações. TPR, TOP 
- Redigir preferencialmente frases curtas, em ordem direta (sujeito< verbo< complemento) e na voz ativa. TFR, ORD, VZA

- Usar palavras conhecidas do (a) cidadão (ã) e evitar termos técnicos, jargão jurídico, estrangeirismos e siglas sem explicar o que elas significam. FLX, TEC, JRG, EST, SIG

- $\quad$ Evitar sequências de substantivos abstratos na frase. SQS

- Preferir verbos em vez de substantivos formados a partir de verbos. NOM

- Usar elementos visuais (ícones, infográficos, fotografias etc) para complementar e reforçar a mensagem do texto. ICN, GRF, IMG

- $\quad$ Sempre que possível, testar a facilidade de leitura do texto com o(a) cidadão (ã). TST

- Entender a comunicação escrita do governo como um diálogo para o exercício da cidadania. PRX

\section{São Paulo}

- Evite escrever frases com mais de 20 palavras. TFR (20)

- Dê preferência ao uso de frases em ordem direta, ou seja, frases na ordem de Sujeito > Verbo > Predicado. ORD

- Quando possível, substitua substantivos que atuam como verbo por verbos que expressam ações diretas. NOM

- Evite o uso de siglas, jargões e termos técnicos desconhecidos para seu público. Se for necessário, explique o significado da sigla após a primeira vez que ela aparecer no texto. SIG, TEC, JRG

- $\quad$ Evite uso de termos que possam ser pejorativos e discriminatórios e palavras estrangeiras. EST, DIS

- Não use termos sexistas. Dê preferência ao plural indefinido ou sempre use as palavras nos dois gêneros. GEN

- Evite uso de palavras "difíceis" para seu público. FLX

- Use títulos e subtítulos para ordenar o conteúdo do seu documento. Mantenha sempre a mesma fonte e estilo para informações do mesmo nível. TIT, TIP

- Use elementos visuais, como diagramas, tabelas e gráfico, para ajudar a explicar o conteúdo ou ideias de um parágrafo. DGM, GRF, TAB

- Use marcadores de tópicos quando precisar separar informações dentro de um parágrafo. TOP 


\section{Apêndice 2}

\section{Termo de consentimento livre e esclarecido (TCLE)}

\section{Termo de consentimento livre e esclarecido}

Documento que se dirige a quem vai participar de uma pesquisa. Traz as informações necessárias para a pessoa avaliar se quer participar. Só assine se você concordar com as condições deste termo.

Programa de Pós-Graduação em Design da PUC-Rio

Laboratório de Ergodesign e Usabilidade de Interfaces da PUC-Rio (LEUI)

Título da pesquisa: O impacto da Linguagem Simples na compreensibilidade textual do benefício "Auxíliodoença" no site do INSS por adultos de alta escolaridade

Nome da pesquisadora responsável: Heloisa Fischer

Nome da orientadora da pesquisa: Claudia Mont'Alvão

Nome da co-orientadora da pesquisa: Erica dos Santos Rodrigues - Programa de Pós-Graduação em Estudos da Linguagem PUC-Rio

Gostaríamos de convidar você a participar pela internet como voluntária(o) de um estudo experimental.
O estudo é uma etapa da pesquisa que estamos fazendo na PUC-Rio. Conheça os detalhes!

\section{OBJETIVO| $O$ que queremos investigar}

O objetivo geral da pesquisa é estimar o papel do estilo de escrita na compreensibilidade de informações sobre serviços públicos digitais. Este estudo experimental pretende investigar como adultos com pósgraduação compreendem as informações sobre um benefício do INSS, com foco nos elementos linguísticos do texto.

\section{JUSTIFICATIVA | Por que essa pesquisa é relevante}

Todos os mais de três mil serviços do governo federal deverão ser oferecidos digitalmente até 2022 , conforme determina a Estratégia Brasileira de Transformação Digital. A oferta de serviços públicos online requer informações fáceis de ler, já que o cidadão tem menos canais de atendimento para esclarecer dúvidas. Mas os textos sobre serviços públicos costumam usar elementos linguísticos que dificultam a leitura mesmo em pessoas com alta escolaridade. Nosso estudo experimental pretende estimar a compreensibilidade textual de um benefício disponível no site do INSS antes e depois de uma alteração no estilo de escrita, usando diretrizes da técnica de comunicação chamada Linguagem Simples. Achados da pesquisa têm o potencial de contribuir com evidência para diversos campos do saber interessados na compreensibilidade da informação pública.

\section{PROCEDIMENTOS METODOLÓGICOS | Como será a sua participação}

O estudo será feito por videochamada, em horário de sua conveniência, previamente agendado, pela plataforma Google Meet, com uso de computador (notebook ou computador de mesa). Não será possível participar pelo celular. A videochamada levará cerca de 15 minutos. Você acessará o link para ler um texto em voz alta e responder algumas perguntas. A sua tela deverá ser compartilhada o tempo todo. A sua câmera e a câmera da pesquisadora ficarão ligadas o tempo todo, mas o foco não será na sua imagem, mas sim na tela onde estarão disponíveis o texto e as perguntas de compreensão. A pesquisadora ficará observando a sua atividade em silêncio. Você poderá falar com ela quando quiser.

INFORMAÇÕES COLETADAS | Os dados que armazenaremos e como iremos usá-los

A videochamada será gravada. Você responderá perguntas sobre o texto, fornecerá dados demográficos (sexo, faixa etária e escolaridade) e responderá algumas perguntas sobre o uso de serviços públicos digitais. As informações coletadas serão usadas exclusivamente na pesquisa de mestrado indicada no cabeçalho deste documento.

\section{BENEFÍCIOS}

Você não receberá qualquer remuneração. De forma direta, a sua participação contribuirá para a nossa pesquisa e para o corpo de conhecimento sobre uso de serviços públicos digitais no Brasil. De forma indireta, você estará contribuindo para informar cientificamente ações que sejam voltadas a atender necessidades dos cidadãos ao interagir com governos pela internet.

\section{CUSTOS}

Você não terá qualquer custo para participar do estudo.

\section{DIREITOS DOS PARTICIPANTES}

Você é livre para encerrar a sua participação a qualquer momento, sem nos avisar. Isso não implicará em qualquer prejuízo para você. Toda nova informação sobre essa pesquisa será passada para você avaliar 
se deseja continuar participando. Você poderá solicitar a interrupção da gravação e o cancelamento da atividade. Será possível fazer uma pausa no meio da atividade, se você quiser.

\section{SIGILO E CONFIDENCIALIDADE DE DADOS}

A sua identidade será tratada com padrões profissionais de sigilo. Seu nome, imagem e voz não aparecerão em nenhuma publicação sobre a pesquisa. Todo material de registro em áudio, vídeo ou fotografia será tratado como confidencial e restrito para uso acadêmico. Os dados coletados ficarão arquivados com a pesquisadora responsável por 5 (cinco) anos.

\section{DESCONFORTOS, RISCOS E INDENIZAÇÃO}

O grau de desconforto será mínimo, semelhante a fazer atividades cotidianas no computador, como ler noticiário e preencher formulários. É possível que o tamanho das letras lhe pareça pequeno: neste caso, bastará ampliar a visualização da sua tela, usando a ferramenta de ampliação do seu computador. Haverá dois campos abertos no formulário, os demais serão múltipla-escolha. Caso você tenha alguma dificuldade para digitar as respostas nesses campos abertos, poderá responder oralmente. Se, mesmo assim, você se sentir desconfortável participando da pesquisa, poderá abandoná-la a qualquer tempo.

\section{AUTORIZAÇÃO PARA USO DE IMAGEM}

As imagens da tela do seu computador serão usadas exclusivamente para a nossa pesquisa. Ao assinar este termo, você autoriza o uso dos resultados alcançados nessa pesquisa para publicações acadêmicas, sempre garantindo o seu anonimato. Tais $\neg$ ᄀ resultados poderão ser publicados com a inserção de imagens da sua tela.

\section{FICOU COM DÚVIDAS?}

Se tiver alguma dúvida sobre esta pesquisa, contacte a pesquisadora responsável Heloisa Fischer a qualquer momento pelo telefone (21) 99189-6187 ou pelo e-mail helofischer@gmail.com. A professora orientadora Claudia Mont'Alvão poderá ser contactada pelo telefone (21) 3527-1595 ou pelo email cmontalvao@puc-rio.br. Você também poderá contactar Câmara de Ética em Pesquisa da PUC-Rio, Rua Marquês de São Vicente, 225 - Gávea, Rio de Janeiro, CEP 22453-900, telefone: (21) 3527-1618. A Câmara é a instância da universidade destinada a avaliar projetos de pesquisa dos professores, pesquisadores e discentes, quando solicitada.

$\mathrm{Eu}$, CPF após ler este documento e esclarecer todas as minhas dúvidas, acredito estar suficientemente informada(o). Está claro para mim que minha participação é voluntária e que posso retirar este consentimento a qualquer momento, sem penalidades ou perda de qualquer benefício. Estou ciente também dos objetivos da pesquisa, dos procedimentos aos quais serei submetida(o), dos possíveis danos ou riscos deles provenientes e da garantia de confidencialidade e esclarecimentos sempre que desejar. Concordo de espontânea vontade em participar deste estudo.

Local, de julho de 2020.

A quarentena e o distanciamento social causados pela pandemia da COVID-19, que ocorreu durante a realização da nossa pesquisa, impediram a impressão desse termo em duas vias. A assinatura da(o) participante foi coletada por meio de resposta positiva em troca de e-mails.

Nome da pesquisadora responsável: Heloisa Fischer

Assinatura da pesquisadora responsável 


\section{Apêndice 3}

Teste de compreensão: critérios que orientaram a elaboração das afirmativas

\section{Afirmativas - Bloco 1}

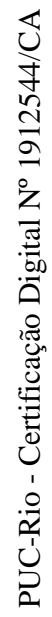

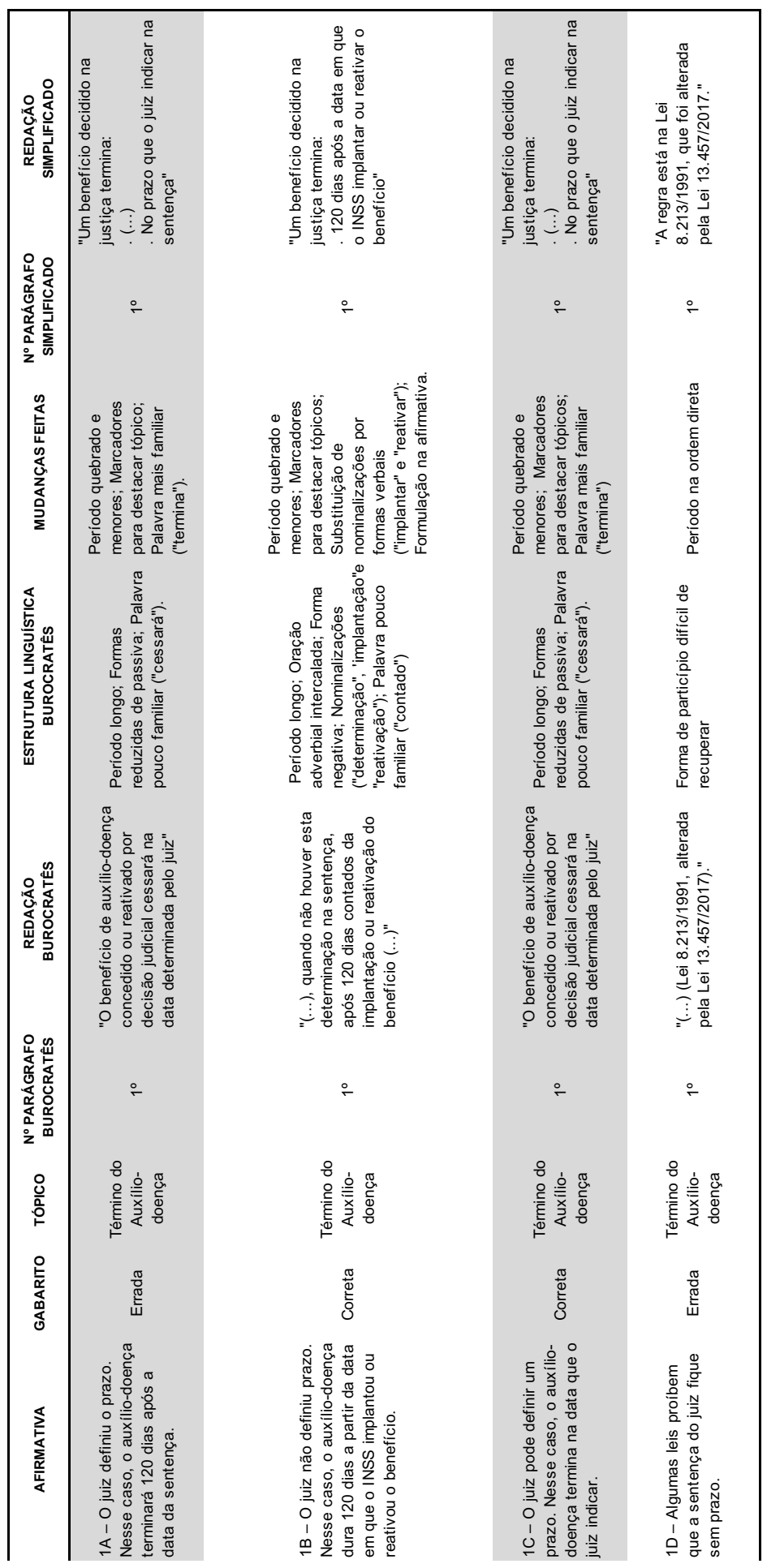


Afirmativas - Bloco 2

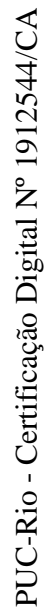

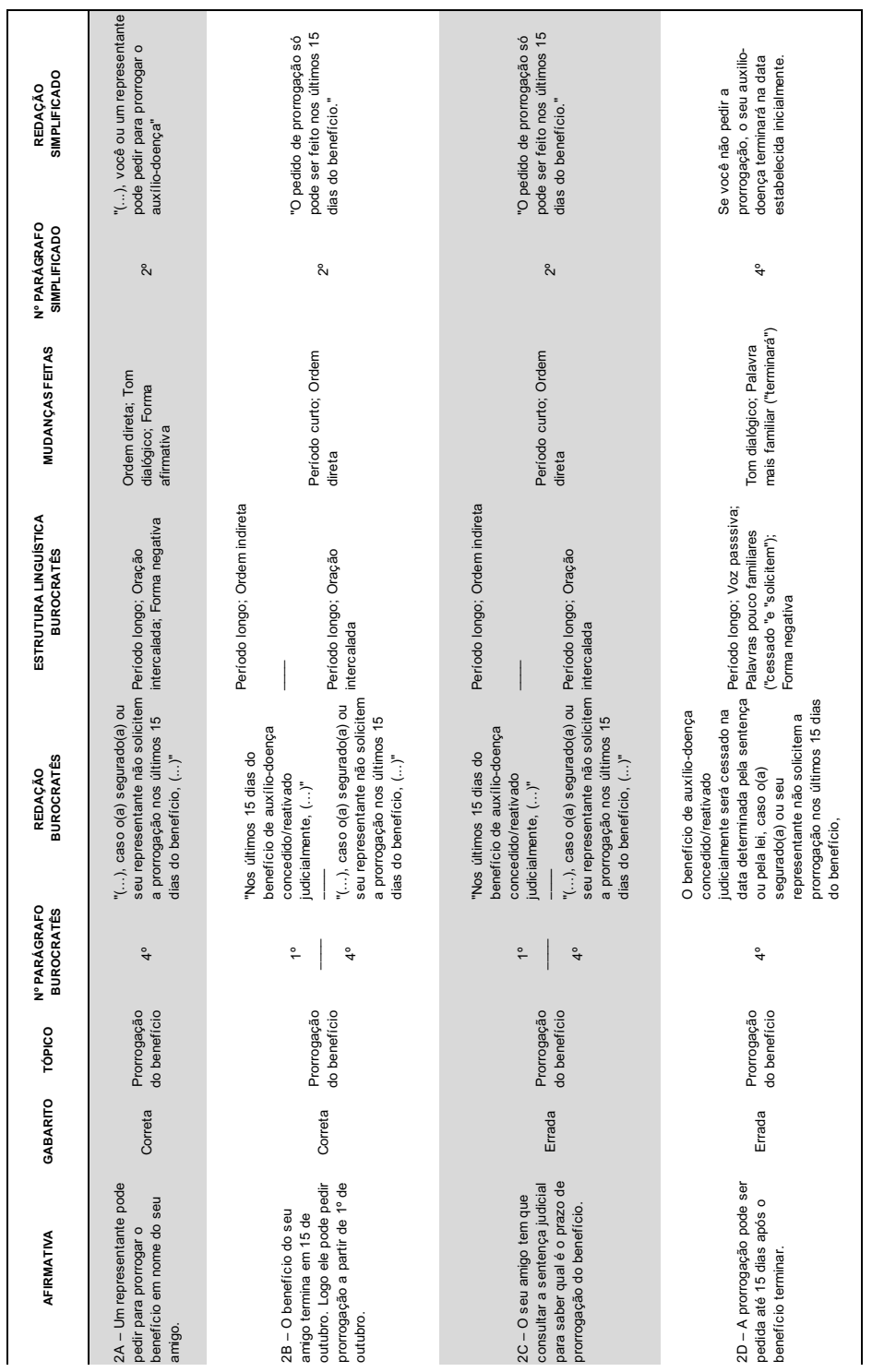


Afirmativas - Bloco 3

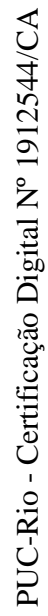

\begin{tabular}{|c|c|c|c|c|}
\hline 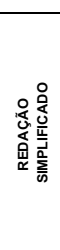 & 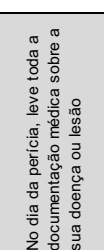 & 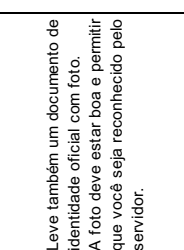 & 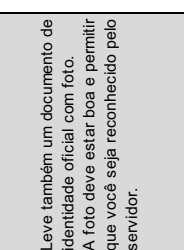 & 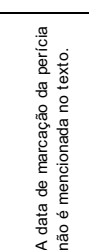 \\
\hline 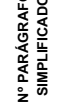 & $\therefore$ & $\therefore$ & $\therefore$ & $\mid$ \\
\hline 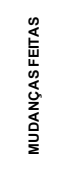 & 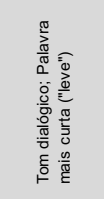 & 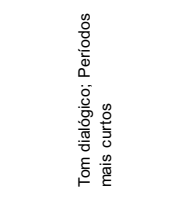 & 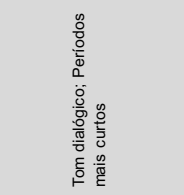 & | \\
\hline 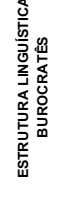 & 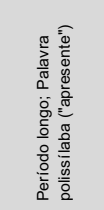 & 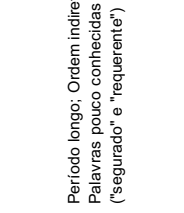 & 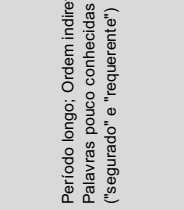 & | \\
\hline 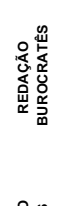 & 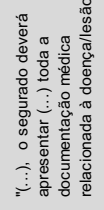 & 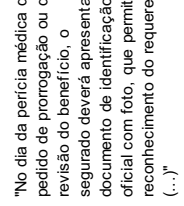 & 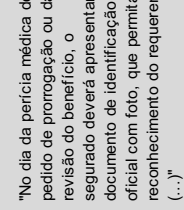 & 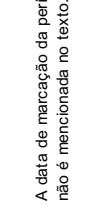 \\
\hline 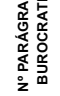 & $\therefore$ & $\therefore$ & $\therefore$ & | \\
\hline 总 & 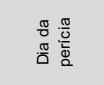 & 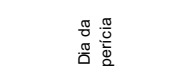 & 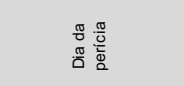 & 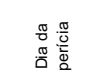 \\
\hline 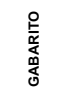 & 愛 & $\frac{\frac{\pi}{0}}{\frac{\tilde{g}}{3}}$ & 密 & 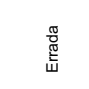 \\
\hline 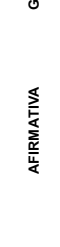 & 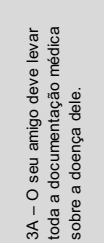 & 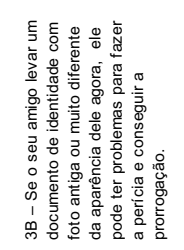 & 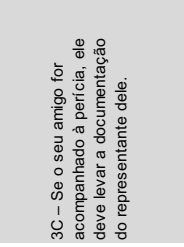 & 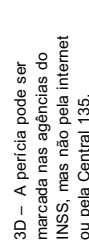 \\
\hline
\end{tabular}




\section{Apêndice 4}

\section{Questionário: Transcrição e categorização das respostas em và pergunta "O que poderia ter sido exposto de modo mais claro no texto?"}

\section{Grupo Simplificado}

\section{Participante 1}

Não tive nenhuma dificuldade, não achei o texto particularmente difícil, mas também não tá facilitado, né?

Podia ser visualmente mais claro não tinha nenhuma ajuda visual para você entender as partes, enfim. Coisas que hoje em dia, em mídia social, enfim você vê, meio que você olha você já entende.

Nenhuma dificuldade

Diagramação (ausência de ajuda visual): devia ter negrito, caixa alta

\section{Participante 2}

Do prazo é muito complicado.

A questão do juiz também podia tá melhor explicada porque é, não fica muito claro ali, só diz ah é o que o juiz disser, mas e aí, né ?

120 dias depois de começado ou reativado: acho que aquilo devia ser em bullets distintos e a formulação da frase de fato podia ser mais simples

Conteúdo informacional - Bloco 1 (prazos do benefício)

Diagramação (texto corrido): bullets

Formulação das frases (devia ser mais simples)

\section{Participante 3}

Já começa falando sobre decisão de juiz e tal, não sei, acho que isso já dá um bloqueio de cara. E a pessoa que tá querendo saber sobre o benefício não quer saber se o benefício foi em qual base a lei ele tem direito ao beneficio

Eu acho que algumas frases são um pouco grandes e aí você acaba tendo que ler ele várias vezes pra ir assimilando as fatias dessas frases.

Conteúdo informacional - Bloco 1 (prazos do benefício)

Conteúdo informacional - Bloco 1 (leis)

Formulação das frases (tamanho grande, exige várias leituras)

\section{Participante 4}

Bom, pra mim, não gerou. Eu achei que estava fácil.

Nenhuma dificuldade

\section{Participante 5}

A questão da foto não fica exatamente clara

A questão da prorrogação poderia ser explicada, talvez, de uma forma mais objetiva quem sabe até numa linguagem visual, numa linguagem mais sintética direta, que você bate o olho e já tá entendendo o que se trata, não um texto tão delongado e discursivo

facilitaria se assim que você batesse o olho e já conseguisse identificar que isso teria a ver um pouco com a organização da informação.

Eu acho que sim, se podia fazer varias secçõezinhas numa linguagem direta

é ruim fazer parágrafos, fica pesante, macivo

Conteúdo informacional - Bloco 2 (prazo da prorrogação) 
Conteúdo informacional - Bloco 3 (foto)

Diagramação (texto corrido, delongado e discursivo): recursos visuais

Organização

\section{Participante 6}

Eu acho que eu fico na dúvida quando fala que um representante pode pedir porque aí de qualquer maneira um representante pede, mas a pessoa precisa ir no dia pra fazer a perícia, então acho que essa parte fica um pouco confusa.

Conteúdo informacional - Bloco 2 (representante)

Conteúdo informacional - Bloco 3 (perícia, não fala se o representante pode substituir)

\section{Participante 7}

O prazo para dar entrada no benefício da prorrogação fica dúbio, algumas pessoas podem ter dificuldades de entender se exatamente quando fizer 15 dias do término, se depois disso ou se nesse período de 15 dias entre 15 dias para o termino nesse tempo todo você tem que pedir a prorrogação.

Conteúdo informacional - Bloco 2 (prazo da prorrogação)

\section{Participante 8}

Se poderia ser um representante ou não, e se esse representante precisaria também levar uma documentação, não se estivesse acompanhando, mas se estiver no lugar do doente.

Conteúdo informacional - Bloco 3 (perícia, não fala se o representante pode substituir)

\section{Participante 9}

O papel do representante. Poderia ficar mais claro que alguém poderia com facilidade pedir a prorrogação

Conteúdo informacional - Bloco 2 (representante)

\section{Participante 10}

primeiro parágrafo quando ele fala sobre a questão dos prazos do benefício, é ficou... eu precisei de voltar lá depois pra entender melhor as outras informações me pareceram claras.

Conteúdo informacional - Bloco 1 (prazos do benefício)

\section{Participante 11}

No comecinho, quando explicam que é pra você prorrogar, né, o beneficio tem as duas opções, né, ou 120 dias, se não me engano, ou depende do que o juiz vai falar. Eu acho que poderia explicar um pouquinho mais isso. Faltou exemplo para ilustrar. Por exemplo: Caso o juiz der 90 dias...

Conteúdo informacional - Bloco 1 (prazos do benefício, faltou exemplo para ilustrar)

\section{Participante 12}

prazo da sentença estabelecida pelo juiz, ou seja, quanto tempo eu vou ter ainda de beneficio depois que o juiz der a sentença.

Conteúdo informacional - Bloco 1 (prazos do benefício)

\section{Participante 13}

Podia ser mais sucinto, mais direto e a forma de disposição do texto também podia tá em destaque as coisas que são mais importantes. Entendeu? Pra você ir direto na... ter informação de forma mais direto. O texto tá.... é confuso, né?

Podiam ser destacadas as coisas importantes. Por exemplo: prazo, modos, podia ter um modo de explicação que fosse mais estrutura do texto

Hierarquia da informação, estrutura. E com o que você chama a atenção também.

Formulação das frases (texto confuso) 
Diagramação (falta destaque às principais informações): recursos visuais Organização

\section{Participante 14}

Perícia: não dá pra entender se quando a pessoa marca pede pra renovar eles já marcam a data da pericia como que? Isso não ficou claro pra mim...assim... tudo bem tem que fazer a pericia mas isso é feito, quando é que é essa pericia, né? Também qual que é o prazo dessa pericia A partir do momento que eu ligo lá pra agendar o que eu quero prorrogar, o prazo, né? É, quanto tempo que demora essa pericia, entende? Quanto tempo que vai demorar para conseguir agendar a perícia.

Pergunta se o amigo precisaria consultar a sentença pra saber o prazo de prorrogação. $\mathrm{Na}$ verdade o prazo de prorrogação é fixo, mas ele tem que saber a data que acaba a sentença então ele precisaria consultar a sentença justamente pra saber quando que acaba o benefício e a entender qual que vai ser.(fala incompreensivel) depois que vai começar abertura o pedido de prorrogação, né? É, então por isso que fiquei nessa dúvida ali em relação aquela pergunta, a essa afirmação.

Essa coisa do texto eu entendi veio mais na pergunta porque eu não entendi direito o que que era eu responder ali, se referia-se só a prazo fixo da prorrogação ou se, entende essa coisa? Que o prazo da sentença pode variar...

Conteúdo informacional - Bloco 3 (perícia, faltou o tempo que leva para agendar)

Conteúdo informacional - Bloco 2 (prazo de prorrogação)

\section{Participante 15}

Quando reli pela terceira vez eu ainda estava com algumas ressalvas se eu tinha fixado todas as informações do prazo do juiz.

Documentação do acompanhante: fiquei na dúvida se uma outra pessoa pode pedir a prorrogação pra você se a documentação que tem que ser levada é do doente e do acompanhante, a pericia sempre tem que ser feita com a pessoa que está doente?

O texto deixa claro que outra pessoa pode solicitar a prorrogação, mas como é que a pessoa prova que ela é outra? Eu sou a filha pedindo pra minha mãe. Ficou essa dúvida. Eu organizaria o texto de outra forma, com outros espaçamentos...tem uns parágrafos, poderia ser mais separado por tópicos... até pra você memorizar melhor, né? Ah, vai pedir a prorrogação? Se é você é dessa forma, se for outra pessoa é de outra forma.

Pode até uma preguiça de ler um parágrafo.

Conteúdo informacional - Bloco 1 (prazos do benefício)

Conteúdo informacional - Bloco 3 (perícia, o representante pode substituir?)

Organização (por temas)

Diagramação (espaçamentos): tópicos

\section{Participante 16}

O prazo não fica claro porque ele fala lá que você tem que pedir nos últimos 15 dias, mas isso eu só consegui pescar depois de umas...depois de ler com muita atenção aquilo.

Prazo de validade do benefício: fala 120 dias a partir do momento que é implementado, mas pode pra menos ou pode pra mais caso o juiz decida isso.

Achei tudo bem confuso.

Conteúdo informacional - Bloco 1 (prazos do benefício)

Conteúdo informacional - Bloco 2 (prazo da prorrogação)

Formulação das frases (texto confuso)

\section{Participante 17}

Eu acho que estava bem claro.

Não explica como marcar a perícia.

Nenhuma dificuldade

Conteúdo informacional - Bloco 3 (perícia, como marcar?) 


\section{Participante 18}

Tive que reler a parte dos 15 dias anteriores ao término do benefício pra ter certeza...

Um representante pode solicitar a prorrogação, mas no dia da perícia quem tem que ir é o beneficiário do auxílio. Eu acho que isso poderia confundir. Como se o representante pudesse fazer todo o processo e o que ele pode fazer, eu entendo que é somente a marcação, não a parte presencial.

Conteúdo informacional - Bloco 2 (prazo da prorrogação)

Conteúdo informacional - Bloco 3 (perícia, o representante pode substituir?)

\section{Participante 19}

Foi na pergunta que eu tive que voltar, porque fala da foto.

Quando li a primeira vez eu não tive a compreensão de que a foto seria de qualquer pessoa que estivesse indo e não só do segurado.

Conteúdo informacional - Bloco 3 (foto)

\section{Participante 20}

A parte que fala do tempo que o INSS dá e a coisa de juíz

$\mathrm{Na}$ verdade, acho que quase todas as partes dão margem a uma certa dúvida, mas essa primeira parte achei que gera mais confusão.

Conteúdo informacional - Bloco 1 (prazos do benefício)

Formulação das frases (texto confuso)

\section{Participante 21}

O grau de simplicidade da informação parece dúbio. Ao mesmo tempo que parece um processo simples, a gente sabe que na prática nunca é... Então provavelmente é capcioso, né, é enganoso...assim, não vai funcionar direito e vai exigir uma série de outras pesquisas e procedimentos. Isso é baseado na experiência, que transcende aí ao texto e a própria. (fala incompreensivel)

Se a gente for se basear apenas no texto, parece simples e claro, deveria funcionar, sim. Informações sobre o representante falhas, insuficientes.

Ao mencionar "internet", além do 135. Ficou genérico, devia especificar o link, porque a gente entra naquele site e não entende nada, né.

Conteúdo informacional - Bloco 2 (representante, informações insuficientes)

Conteúdo informacional - Bloco 2 (internet, faltou incluir o link)

\section{Grupo Burocratês}

\section{Participante 1}

Ficou claro.

Na hora dos 120 dias, eu confesso que não lembrava. Fiquei também em dúvida sobre aquela documentação, se a foto estaria, se mesmo com a foto antiga se passaria, mas pelo o que vi ali no texto precisaria uma foto que tivesse identificando bem.

Nenhuma dificuldade (ficou claro)

Conteúdo informacional - Bloco 1 (prazos do benefício)

Conteúdo informacional - Bloco 3 (foto)

\section{Participante 2}

Pericia: ela não é citada em lugar nenhum até ali de repente já aparece um dia da pericia. Falta dizer que o processo de prorrogação demanda uma perícia. A história do representante também caiu de paraquedas, não está muito clara como é que o representante entra nessa história. Especialmente se a pericia envolve a presença da pessoa que está pedindo a prorrogação ou não. Em quais situações, se ele não puder estar na perícia que aí você pode utilizar um terceiro para poder apoiar? 
Reativação: foi uma palavra que ficou batendo na minha cabeça. me deu a impressão que você pode ter o beneficio a primeira vez e eventualmente se a doença voltar você reativa, né, pelo mesmo período. Eu tive que imaginar isso pra poder entender porque dessas duas formas, né, de usar o beneficio.

Conteúdo informacional - Bloco 3 (perícia)

Conteúdo informacional - Bloco 4 (representante) paraquedas

Escolha de palavras ("reativação")

\section{Participante 3}

O texto é todo muito confuso. Toda essa história da sentença, a falta de clareza sobre o quanto vale de fato o prazo e se o juiz e a decisão de a informação que é nova do fato do juiz poder ou não estabelecer uma sentença.

As informações do primeiro parágrafo e do último paragrafo têm o mesmo miolo, mas estão escritas de forma diferente é sobre a validade do beneficio e da sentença, 120 dias, 15 dias acho que os prazos todos estão muito confusos

Tem muitos números que se confundem no primeiro paragrafo.

E vc tem que solicitar uma prorrogação 15 dias antes e se você ainda tiver doente você precisa ir lá presente pra pedir uma prorrogação, isso é uma maluquice!

A história do representante também, no fim. Isso não tá claro, né, se o cara...como assim representante? Mas o q faz dele representante? Será que precisa de uma procuração? Qualquer um que achar alguma coisa, né, um parente, né, dá a impressão de que tem tanta fraude por causa da falta de clareza da história. Um monte de laranja pendurada no INSS e a gente paga por isso.

Porque a única coisa que precisa é um representante que você não sabe como prova que é, levar um documento qualquer levar com um atestado fake e pronto, prorrogou a tua licença.

Conteúdo informacional - Bloco 1 (prazos do benefício)

Conteúdo informacional - Bloco 1 (muitos números)

Conteúdo informacional - Bloco 2 (prazo prorrogação)

Conteúdo informacional - Bloco 4 (representante - faltam requisitos) paraquedas

Repetição de informações (Bloco 1 e Bloco 4)

Formulação das frases (texto confuso)

\section{Participante 4}

A parte sobre as datas e prazos quando que pode pedir esse auxilio do INSS e quando que termina.

Conteúdo informacional - Bloco 1 (prazos do benefício)

Conteúdo informacional - Bloco 2 (prazos da prorrogação)

\section{Participante 5}

Saber se o juiz poderia dar o prazo, entendeu? Porque parece que 120 dias já estava automático na primeira leitura, né?

Também se alguém poderia requerer, aquilo ali parece que eu não encontrei, não sei se eu passei batido. Eu fiquei em dúvida e voltei realmente não encontrei também, pelo menos assim, passando o olho, né? Aquela central 135 eu não entendi o que era.

Conteúdo informacional - Bloco 1 (prazos do benefício)

Conteúdo informacional - Bloco 2 (Central 135)

Conteúdo informacional - Bloco 4 (representante)

\section{Participante 6}

A parte da documentação no final, último paragrafo: eu acho que deveria ficar mais claro o procedimento. Procedimento 120 dias ou dentro do prazo determinado pelo juiz e depois o que tem que fazer? Eu acho que tem que ser mais passo a passo.

Primeiro, seguir o prazo, primeiro é o prazo, segundo... poderia chamar mais, poderia também destacar atenção tem que se pedir 15 dias de antecedência. Isso tá meio perdido ali, a pessoa pode não entender isso. Devia ter um destaque: um negrito, atenção em caixa alta - Atenção o 
prazo a solicitar tem que ser 15 dias antes. Esse é o ponto crucial, são os prazos. Tudo que tem a ver com prazo deveria estar mais destacado. E o prazo fundamental são os 15, antes dos 15 dias do esgotamento do prazo dado pelo juiz ou 120 dias. Esse prazo não está suficientemente destacado e se a pessoa perde esse prazo é 14 dias ele não vai poder obter o beneficio outra vez. De uma maneira geral eu achei o texto razoavelmente fácil de entender, as palavras, mas eu acho que a estrutura poderia ser melhor.

Conteúdo informacional - Bloco 2 (prazo da prorrogação)

Conteúdo informacional - Bloco 3 (documentação)

Conteúdo informacional - Bloco 4 (prazos do benefício)

Diagramação (ausência de destaque): devia ter negrito, caixa alta

Organização (estrutura confusa)

\section{Participante 7}

No início, tem alguma coisa repetida assim, né? De determinada ou determinado. Me deu uma confusão, que eu tive que voltar e reler. $\mathrm{O}$ final meio repete o inicio, era meio a mesma coisa. Isso me incomodou, pareceu repetido. Eu falei pra mim, mas é a mesma informação de cima? Escolha de palavras ("determinada" e "determinação)

Repetição de informações (Bloco 1 e Bloco 4)

\section{Participante 8}

É um tema árido, acho difícil de compreender mesmo. Sendo médica, lido com essas perguntas eu tenho dificuldade de entender esse conteúdo. Não acho um conteúdo simples nem fácil de compreender. Se eu fosse pra tentar uma coisa mais clara eu acho que colocaria em forma de bullets, de.... e não em forma de um texto corrido.

As leis sempre complicam, ter número de lei, ano de lei. Não acho isso útil pra quem tá com uma informação prática.

Conteúdo informacional - Bloco 1 (leis)

Diagramação (texto corrido): devia ter bullets

\section{Participante 9}

Sempre que tem representante/representado, eu fico me perguntando a quem ele está se referenciando. Acabo me perdendo um pouco na leitura. Os parágrafos, eles sempre são muito grandes. Eu meio que me canso e aí tenho que voltar tudo de novo.

Os parágrafos não têm ponto, é tudo uma frase só, isso se torna muito cansativo então a pessoa com certeza vai se perder no meio do texto. Poderia ser apresentado, eu acho em tópicos. Por exemplo: Quais são os documentos que você precisa pra ir pra perícia, aqui. Coloca em tópico é muito mais fácil de visualizar. Um monte de coisa dá pra colocar em tópico ou tabela.

Só me lembrava de informações sobre a perícia, daqui de cima eu não lembrava. Como o texto é cansativo eu só lembrava do final.

Escolha de palavras ("representante")

Formulação das frases (tamanho grande)

Diagramação (texto corrido): devia ter tópicos

Sobrecarga de informação (exige memória)

\section{Participante 10}

Aquela parte do juiz, que ficou assim... ficou clara quando li pela segunda vez, mas quando eu li pela primeira vez eu não consegui perceber se os 120 dias era do juiz ou não. Se eu não estivesse fazendo esse teste aqui eu ia achar que fui eu que não li direito.

Conteúdo informacional - Bloco 1 (prazos do benefício)

\section{Participante 11}

A gente tem uma leitura normalmente diagonal, rápida, tentando pegar as vezes o contexto do texto, né?

Usar negrito ou itálico alguma coisa porque a gente tende a ler mais contextos ou algo que chame mais atenção, que é mais crítico, prioritário do que mesmo ler palavra a palavra num 
texto. Muita repetição de palavras com ... nesses textos e palavra que eu acho poderiam, um texto que poderia ter sido reduzido, sido um pouco mais simplificado, né, porque aí você vai lendo o texto e aí as vezes no paragrafo seguinte como é que meio que você esquece o primeiro parágrafo você estando no segundo, o que foi mesmo o primeiro disse? Será que tá coerente com o segundo?

Os números quando falavam nos prazos, né, e aí era meio o que eu queria calcular pra meio que ver se estava batendo, né, se tava sendo falado.

Sou muito a favor de tabelas, de você organizar em áreas temáticas, por exemplos : prazo limite do auxílio, aí a descrição e no lado a data, né. E depois outro prazo máximo pra prorrogação... enfim. Eu sou muito a favor de tabelas ou pelo menos você destacar algumas palavras chaves. Tópicos pra mim têm a mesma funcionalidade que uma tabela por exemplo.

Conteúdo informacional - Bloco 1 (prazos do benefício)

Conteúdo informacional - Bloco 2 (prazo da prorrogação)

Diagramação (texto corrido): devia ter tópicos, tabelas, destaque de palavras-chave

Sobrecarga de informação (exige memória)

Repetição de informações

Organização (por temas)

\section{Participante 12}

Não é claro no inicio, se você pode fazer isso por conta própria ou pode ter um representante. Ele só fala isso no final.

Não fica claro se também o representante tem que levar algum documento

Uma coisa que não fica clara é se o paciente for inválido se pode ir só o representante. Caso o paciente esteja acamado, né, ou hospitalizado como que ele pode fazer?

Significa que, se a gente está solicitando uma prorrogação do benefício supõe que o paciente não esteja bem ainda e a gente não sabe quão mal ele estar.

A questão do prazo ser 15 dias antes pode gerar uma certa dificuldade,

Conteúdo informacional - Bloco 2 (prazo de prorrogação)

Conteúdo informacional - Bloco 3 (perícia)

Conteúdo informacional - Bloco 4 (representante) paraquedas

\section{Participante 13}

Juiz pode dar um prazo, mas se não der é 120 dias. Podia começar dizendo que só dura 120 dias e que você tem que ficar atento pra necessidade de reativar é 15 dias antes do término do prazo, né? Basicamente é isso que eles estão querendo dizer com aquele bando de texto lá...

Pra quem tá lendo, se fica, tipo assim, aquela massa de texto já vê que o negócio é complicado.

Conteúdo informacional - Bloco 1 (prazos do benefício)

Conteúdo informacional - Bloco 2 (prazo da prorrogação)

Organização

Diagramação (massa de texto)

\section{Participante 14}

Representante: enfatiza muito pouco a questão do representante. Não é muito claro pra mim como o represente deve agir, nem qual documentação. Parece que o texto foi formatado pro caso do solicitante do auxílio doença não tem representante. Eu ignorei justamente a questão do representante, não me passou pela cabeça isso.

Também não fica claro se não é possível pedir prorrogação após esse prazo, na minha interpretação de texto como de 15 dias antes, né? Se depois de rompido esse prazo se não existe outro caminho.

Juiz determina um prazo: na minha primeira leitura eu tinha entendido que juiz tinha liberdade. Com as afirmações eu fiquei na dúvida se era realmente o caso e depois eu reli e me parece que efetivamente era esse o caso. Se a legislação citada ali na verdade impede um prazo maior, num limite, uma decisão judicial sem limite...aí talvez eu não tenha pego isso.

Conteúdo informacional - Bloco 1 (prazos do benefício)

Conteúdo informacional - Bloco 1 (leis) 
Conteúdo informacional - Bloco 2 (prazo da prorrogação)

Conteúdo informacional - Bloco 4 (representante) paraquedas

\section{Participante 15}

Principalmente a questão do representante. Não fica claro essa questão se o representante, ele pode representar também na perícia médica, não ficou evidente isso.

O texto repetiu uma ideia no segundo e no quarto parágrafo. Quando eu li o quarto parágrafo eu voltei pro segundo pra ver se tinha alguma coisa diferente, pra ver se tinha alguma a mais ou complementar. Eu comparei os 2 parágrafos.

$\mathrm{Eu}$ talvez reescreveria o quarto parágrafo pra ele ser um pouquinho mais explicativo do resto... ou então não explicativo, um pouquinho mais, com o resumo mais direto do restante, tipo a concluir, então qualquer dúvida entre em contato com... Eu senti falta desse em qualquer dúvida entre em contato ou acesse aqui. Diz pra marcar no 135, mas não falou pra tirar dúvidas Conteúdo informacional - Bloco 4 (representante)

Conteúdo informacional - Bloco 4 (faltou o que fazer em caso de dúvida)

Repetição de informações (Bloco 2 e Bloco 4)

\section{Participante 16}

$\mathrm{O}$ texto tá bem escrito.

Só voltei na questão da decisão judicial.

Nenhuma dificuldade (texto bem escrito)

Conteúdo informacional - Bloco 1 (prazos do benefício)

\section{Participante 17}

A questão da documentação ser bem identificada. Acho que ela precisa ser esclarecida. Inclusive que tem uma lei no Brasil que a carteira de identidade tem um determinado tempo de validade.

Frases longas

Conteúdo informacional - Bloco 3 (foto)

Formulação das frases (tamanho grande)

\section{Participante 18}

Prazo da decisão do juiz. Não ficou claro pra mim se o juiz poderia não marcar um prazo Conteúdo informacional - Bloco 1 (prazos do benefício)

\section{Participante 19}

Faltou a informação sobre o que é necessário pro representante. É mencionado que o representante poderia entrar com pedido, mas não os requisitos.

Faltou um detalhamento ou um alerta sobre o que é necessário para um representante. Aliás, se a pessoa ela tá com algum problema de saúde é natural que ela precise recorrer a um representante.

Algumas frases eu achei um pouco longas. Não achei um texto tão obscuro, mas ele poderia talvez ser um pouco mais claro, com períodos mais curtos Conteúdo informacional - Bloco 4 (representante - faltam requisitos)

Formulação das frases (tamanho grande)

\section{Participante 20}

Representante: fiquei em dúvida quanto à documentação.

O representante ele poderia se a pessoa tá muito doente é normal que ele possa levar a documentação e tudo mais no nome da pessoa que tá solicitando. Mas eu não sei, em outras partes não ficou assim muito nítida essa questão de tem que ser a pessoa ou pode ser a pessoa e o representante. Eu fiquei na dúvida quanto essa ambiguidade, assim.

Eu achei que ficou um pouquinho atrapalhada a redação do texto, um pouco misturada as informações, texto um pouquinho bagunçado e as vezes não muito nítido o que pode ser a pessoa ou o seu representante. 
Prazo 120 dias ou do juiz: fazer uma redação mais nítida quando fosse o caso de ser uma decisão judicial.

Conteúdo informacional - Bloco 1 (prazos do benefício)

Conteúdo informacional - Bloco 4 (representante)

Organização (informações misturadas)

Formulação das frases (redação atrapalhada)

\section{Participante 20}

Pra ser sincero, o texto é muito mal escrito. Eu reescreveria todo ele. Extremamente mal escrito. É, fica até difícil de dizer o que que eu mudaria especificamente. Na realidade, eu mudaria ele totalmente.

Formulação das frases (texto mal escrito) 


\section{Apêndice 5}

Questionário: Lista de adjetivos atribuídos à experiência de usar serviços públicos na internet (originais e editados)

\section{Grupo Burocratês}

\begin{tabular}{|c|c|c|}
\hline Participante & Resposta original & Adjetivos editados \\
\hline 1 & INSEGURANÇA E RAPIDEZ & gera insegurança, rápida \\
\hline 2 & * & * \\
\hline 3 & Redundante; confuso. & redundante, confusa \\
\hline 4 & Confusa e irritante & confusa, irritante \\
\hline 5 & Trabalhoso e confuso & trabalhosa, confusa \\
\hline 6 & $\begin{array}{c}\text { estressante, demorado (velocidade de } \\
\text { carregamento da página e muitos cliques pra } \\
\text { conseguir concluir) }\end{array}$ & estressante, demorada \\
\hline 7 & Simples. Direto & simples, direta \\
\hline 8 & exaustivo, frustrante & exaustiva, frustrante \\
\hline 9 & $\begin{array}{l}\text { Interessante } \\
\text { útil }\end{array}$ & interessante, útil \\
\hline 10 & CONFUSO AMEDRONTADOR & confusa, amedrontadora \\
\hline 11 & confuso, com obstáculos & confusa, com obstáculos \\
\hline 12 & $\begin{array}{l}\text { Satisfatória e eficiente (Sigepe, Detran Rj, esocial, } \\
\text { e-cac). }\end{array}$ & satisfatória, eficiente \\
\hline 13 & Sofrível, estressante & sofrível, estressante \\
\hline 14 & Desânimo Inquietação & desanimadora, inquietante \\
\hline 15 & Ruim e lento & ruim, lenta \\
\hline 16 & medo e dúvida & amedrontadora, gera dúvidas \\
\hline 17 & confuso e estressante & confusa, estressante \\
\hline 18 & confuso,omisso & confusa, omissa \\
\hline 19 & $\begin{array}{c}\text { razoável, insuficiente (dificuldade para encontrar } \\
\text { as informações) }\end{array}$ & razoável, informação dispersa \\
\hline 20 & $\begin{array}{l}\text { Simplificado e carecem detalhes para casos mais } \\
\text { específicos. }\end{array}$ & simplificada, mal detalhada \\
\hline 21 & $\begin{array}{c}\text { positiva, evolução (sinto que sendo aprimorado } \\
\text { ao longo dos anos) }\end{array}$ & positiva, aprimorada \\
\hline
\end{tabular}




\section{Grupo Simplificado}

\begin{tabular}{|c|c|c|}
\hline Participante & Resposta original & Adjetivos editados \\
\hline 1 & $\begin{array}{l}\text { A informação deseja nem sempre é a primeira } \\
\text { coisa que se vê. Ela está envolvida com outras } \\
\text { informações, contextos e essa leitura é cansativa. }\end{array}$ & informação dispersa, cansativa \\
\hline 2 & complexa, incompleta & complexa, incompleta \\
\hline 3 & trabalhoso e cansativo & trabalhosa, cansativa \\
\hline 4 & Frustante, Confusa & frustante, confusa \\
\hline 5 & confuso e antiquado & confusa, antiquada \\
\hline 6 & Irritante, estressante & irritante, estressante \\
\hline 7 & Prático e interface simples (imposto de renda) & prática, simples \\
\hline 8 & * & * \\
\hline 9 & $\begin{array}{l}\text { Confusa, perdida, na dúvida. Medo de cometer } \\
\text { erros com o governo. }\end{array}$ & confusa, amedrontadora \\
\hline 10 & Não foi intuitivo, foi confuso. & não-intuitiva, confusa \\
\hline 11 & Tenso, mas satisfatório, pois acaba dando certo. & tensa, satisfatória \\
\hline 12 & Desagradável e Complicada & desagradável, complicada \\
\hline 13 & Juridiquês e burocracia extensa (Faz 2 anos) & difícil de entender, burocrática \\
\hline 14 & Confusa e insatisfatória & confusa, insatisfatória \\
\hline 15 & complicado pouco claro & complicada, pouco clara \\
\hline 16 & tem que ter paciência e acaba compreendendo & requer paciência, compreensivel \\
\hline 17 & $\begin{array}{c}\text { Imposto de renda: achei claro, mas muito dispersa } \\
\text { a informação. (Cheio de vai e volta). }\end{array}$ & clara, informação dispersa \\
\hline 18 & $\begin{array}{l}\text { Útil e fácil de navegar (site da receita por } \\
\text { conhecimento prévio), mas já tive experiências } \\
\text { bem penosas em outros sites. }\end{array}$ & útil, penosa \\
\hline 19 & Confuso e pouco esclarecedor & confusa, pouco esclarecedora \\
\hline 20 & Estressante e muito estressante & estressante, estressante \\
\hline 21 & pouco esclarecedores, confuso & pouco esclarecedora, confusa \\
\hline
\end{tabular}




\section{Apêndice 6}

Teste de compreensão: Scores individuais das três variáveis dependentes

\begin{tabular}{|cc|}
\hline \multicolumn{2}{|c|}{$\begin{array}{c}\text { No de acertos na } \\
\text { primeira leitura }\end{array}$} \\
\hline Burocratês & Simplificado \\
\hline 10 & 11 \\
10 & 11 \\
8 & 10 \\
10 & 10 \\
7 & 10 \\
10 & 12 \\
8 & 11 \\
11 & 10 \\
9 & 9 \\
9 & 12 \\
11 & 12 \\
10 & 8 \\
11 & 10 \\
10 & 10 \\
6 & 10 \\
8 & 11 \\
6 & 12 \\
9 & 10 \\
9 & 11 \\
10 & 11 \\
7 & 10 \\
\hline
\end{tabular}




\begin{tabular}{|cc|}
\hline \multicolumn{2}{|c|}{$\begin{array}{c}\mathbf{N}^{\circ} \text { de releituras para } \\
\text { conferir ou ajustar } \\
\text { respostas }\end{array}$} \\
\hline Burocratês & Simplificado \\
\hline 1 & 1 \\
1 & 2 \\
1 & 0 \\
1 & 3 \\
1 & 0 \\
1 & 0 \\
1 & 0 \\
3 & 0 \\
1 & 1 \\
0 & 1 \\
3 & 1 \\
0 & 0 \\
0 & 1 \\
0 & 0 \\
2 & 0 \\
0 & 0 \\
1 & 0 \\
3 & 0 \\
5 & 1 \\
1 & 0 \\
1 & \\
\hline
\end{tabular}




\begin{tabular}{|c|c|}
\hline \multicolumn{2}{|c|}{$\begin{array}{c}\text { Tempo para completar } \\
\text { o teste de compreensão } \\
\text { (em segundos) }\end{array}$} \\
\hline Burocratês & Simplificado \\
\hline 110 & 176 \\
\hline 211 & 273 \\
\hline 209 & 234 \\
\hline 156 & 138 \\
\hline 240 & 227 \\
\hline 255 & 81 \\
\hline 209 & 155 \\
\hline 274 & 176 \\
\hline 174 & 164 \\
\hline 128 & 191 \\
\hline 262 & 280 \\
\hline 139 & 119 \\
\hline 267 & 177 \\
\hline 159 & 155 \\
\hline 256 & 267 \\
\hline 125 & 221 \\
\hline 273 & 122 \\
\hline 414 & 87 \\
\hline 318 & 159 \\
\hline 287 & 301 \\
\hline 218 & 171 \\
\hline
\end{tabular}




\section{Anexo 1}

Reprodução da primeira página das diretrizes governamentais de Linguagem Simples coletadas no levantamento documental

Diretrizes em língua inglesa

Austrália

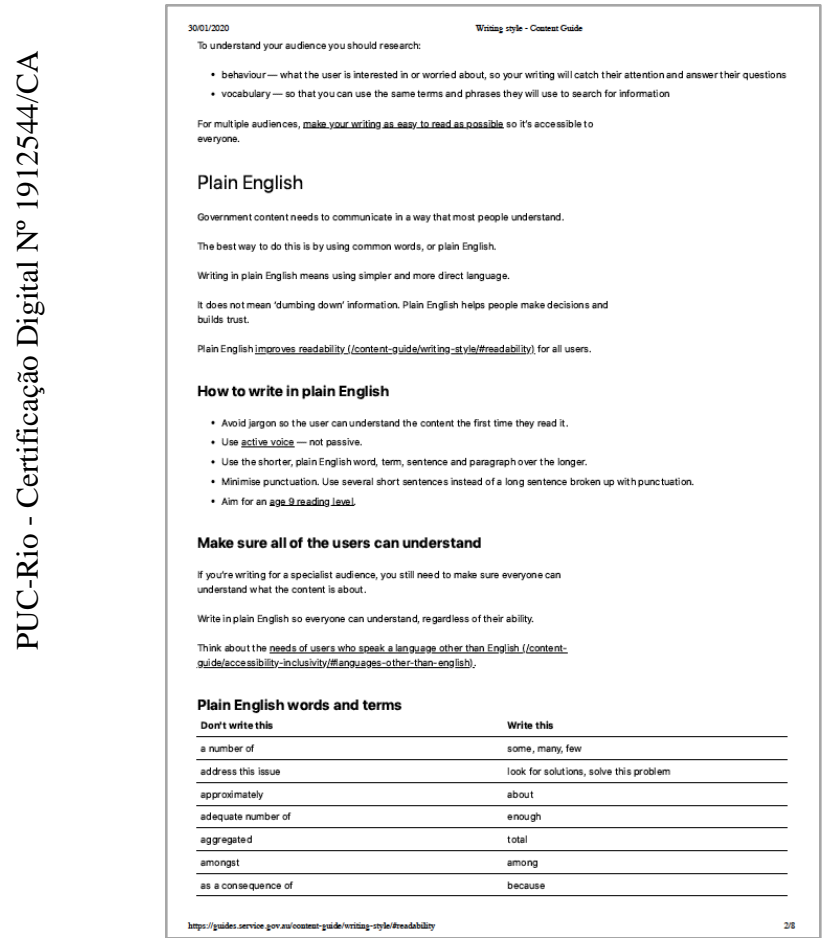

Canadá

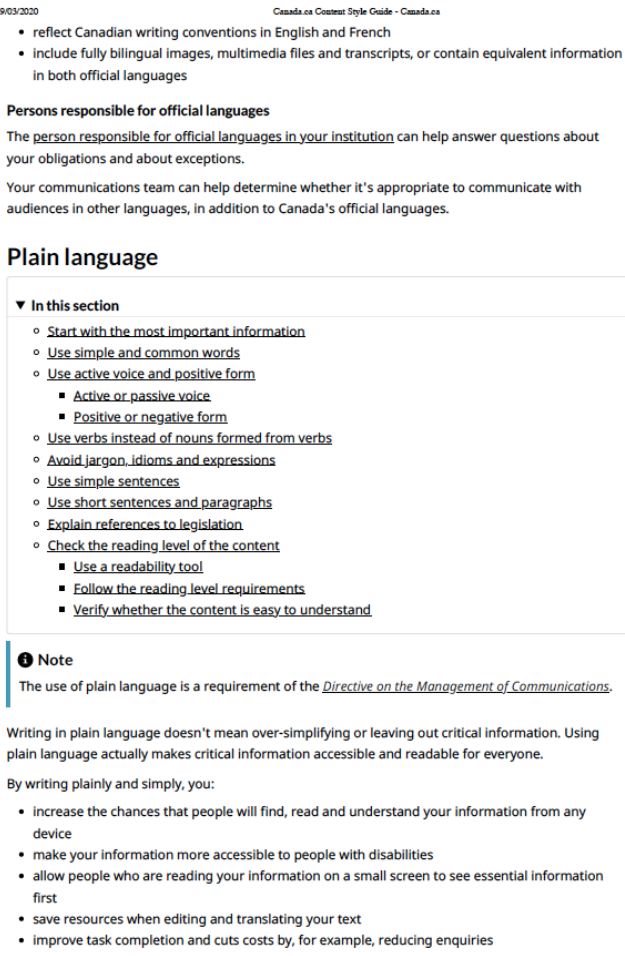


Diretrizes em língua inglesa

\section{Estados Unidos}

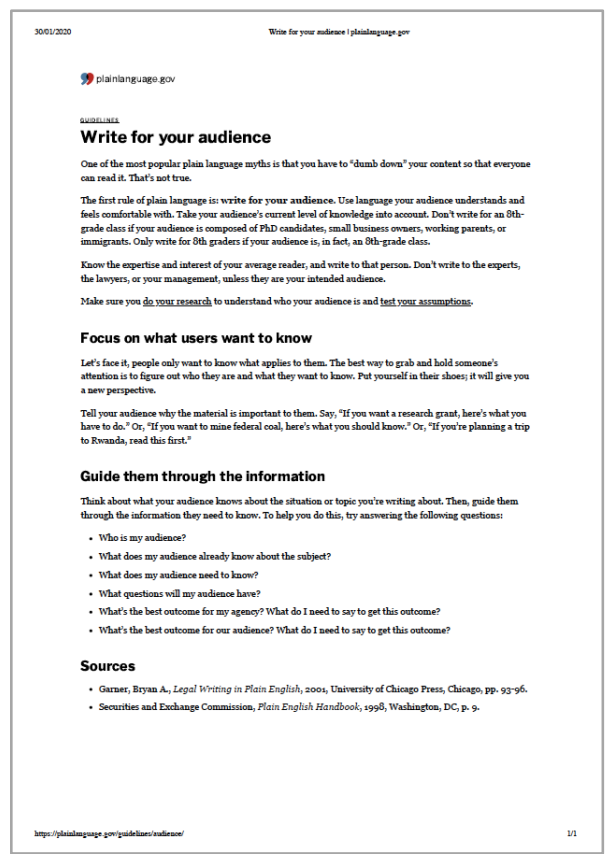

\section{Nova Zelândia}

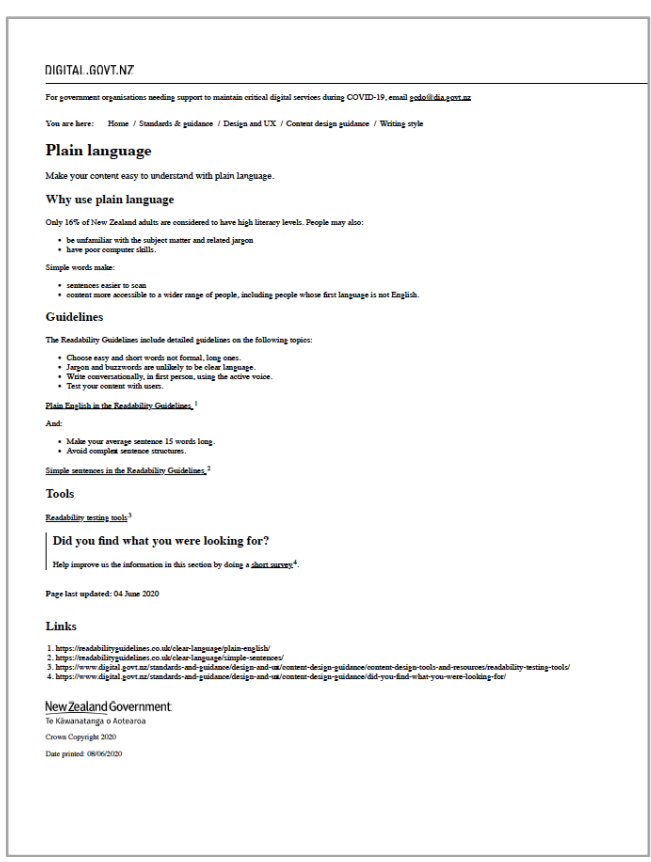

\section{Reino Unido}

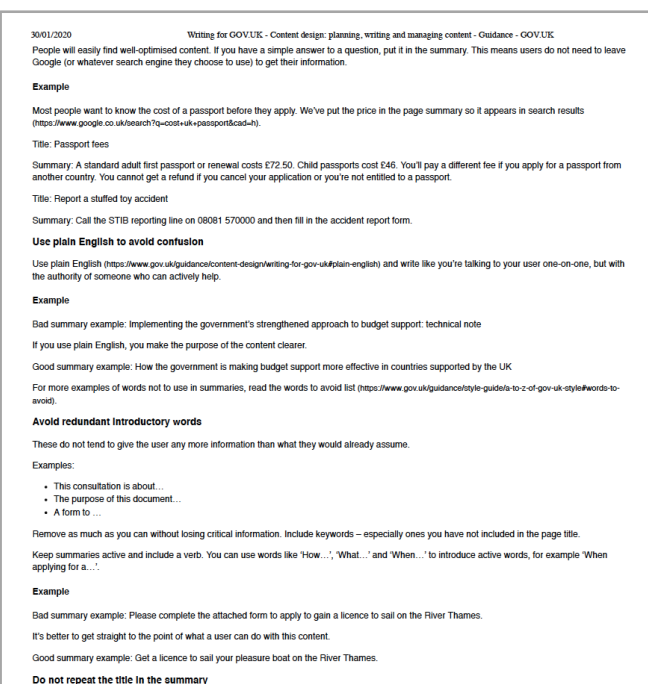


Diretrizes em língua espanhola

\section{Chile}

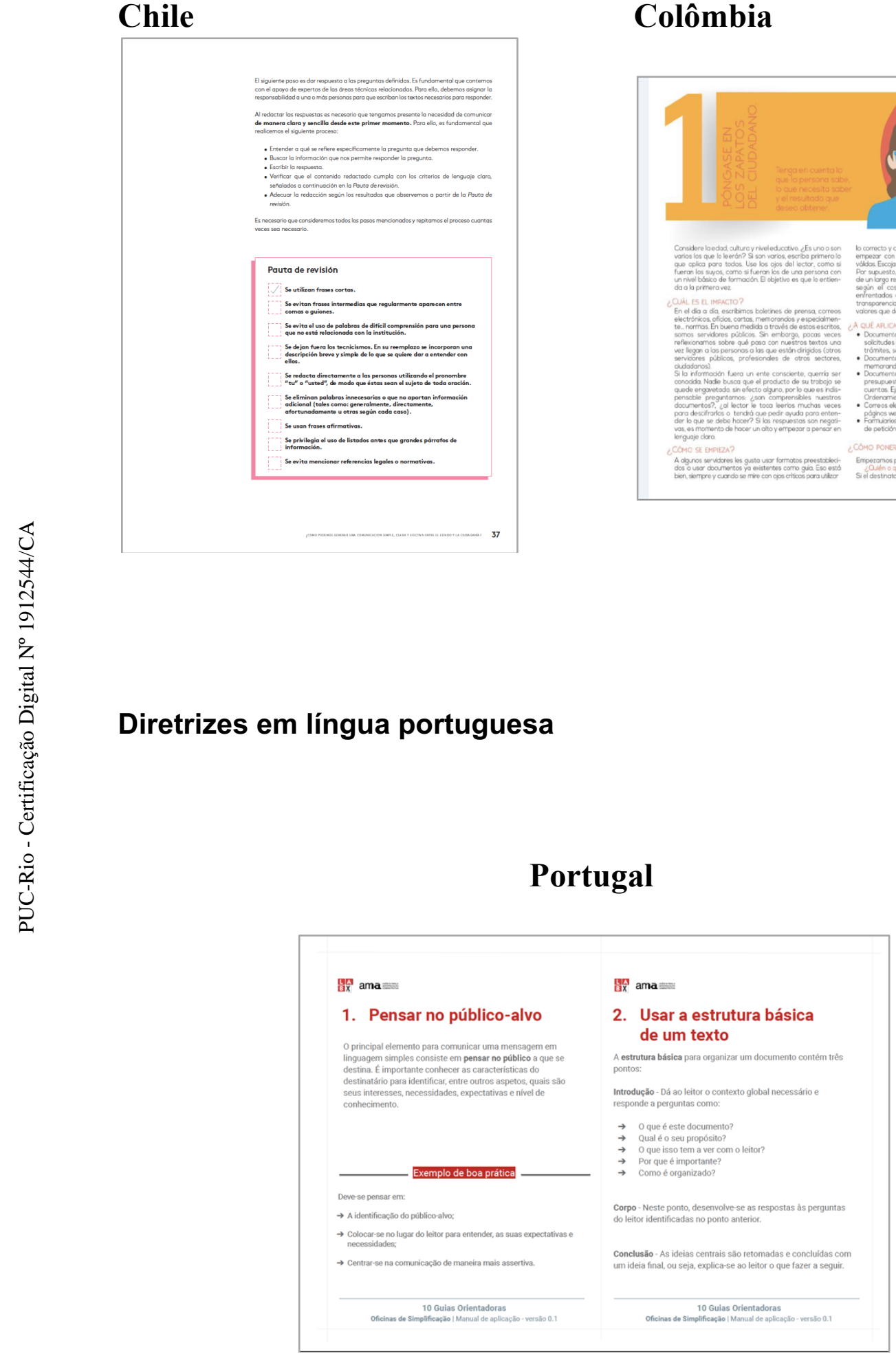


Diretrizes em língua portuguesa

\section{Brasil}

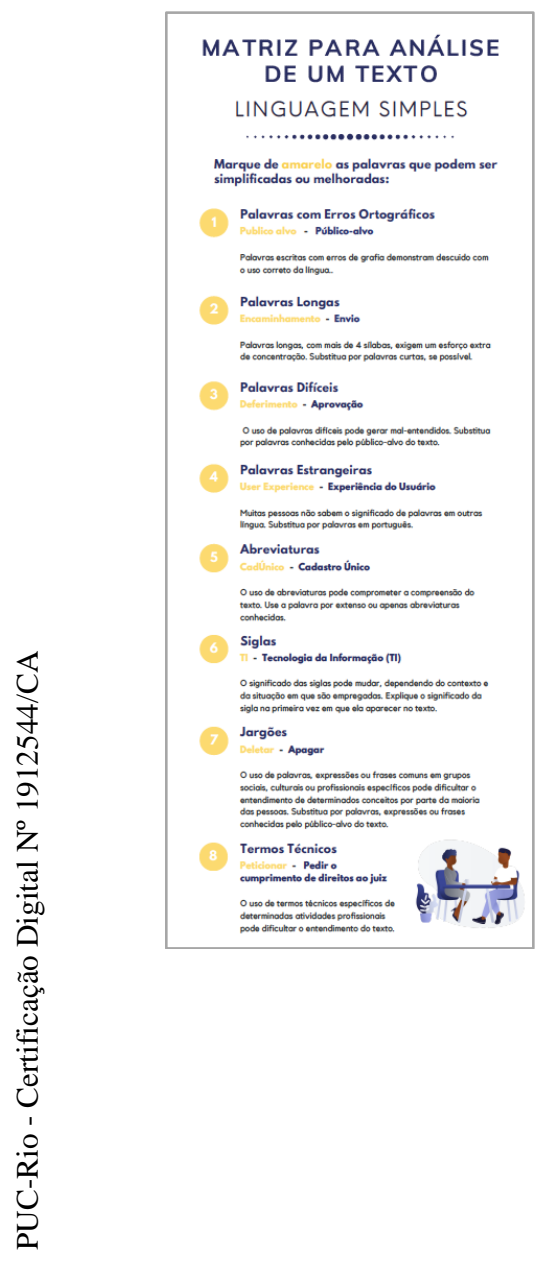

\section{Ceará}

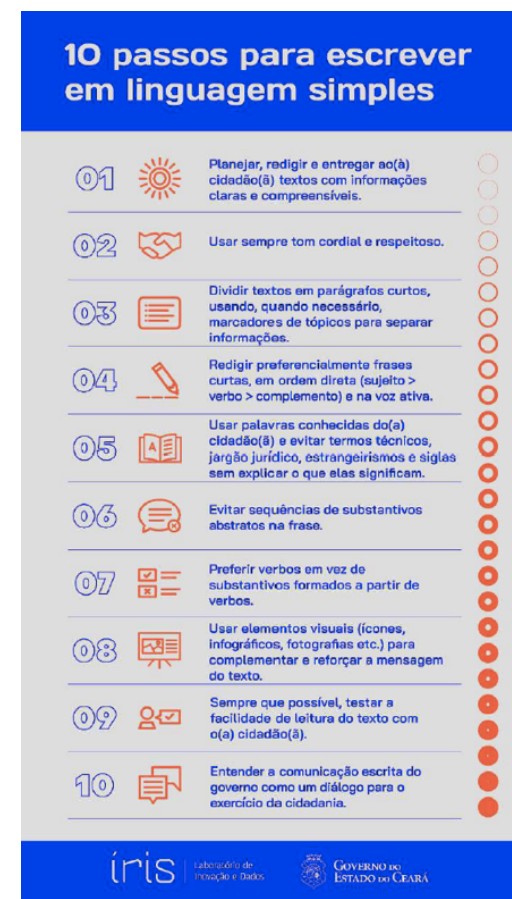

\section{São Paulo}

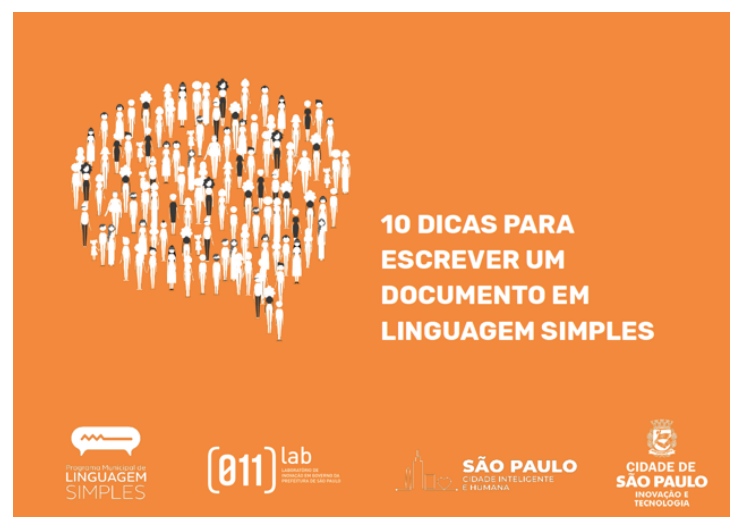




\section{Anexo 2}

\section{Parecer positivo da Comissão da Câmara de Ética em Pesquisa da PUC-Rio}

\section{Pontifícia Universidade Católica $_{\text {a }}$ DO RIO DE JANEIRO}

CÂMARA DE ÉTICA EM PESQUISA DA PUC-Rio

Parecer da Comissăo da Câmara de Ética em Pesquisa da PUC-Rio 056/2020 - Protocolo 76/2020

A Câmara de Ética em Pesquisa da PUC-Rio foi constituída como uma Câmara especifica do Conselho de Ensino e Pesquisa conforme decisão deste órgão colegiado com atribuição de avaliar projetos de pesquisa do ponto de vista de suas implicações éticas.

Identificação:

Título: "O impacto da Linguagem Simples na compreensibilidade textual do beneficio " Auxílio Doença" no site do INSS por adultos de alta escolaridade" (Departamento de Artes \& Design da PUC-Rio) Autora: Heloisa Fischer de Medeiros Pires (Mestranda do Departamento de Artes \& Design da PUCRio)

Orientadora: Claudia Renata Mont,Alvão Bastos Rodrigues (Departamento de Artes \& Design ) Coorientadora: Erica dos Santos Rodrigues (Professora do Departamento de Letras da PUC-Rio)

Apresentação: Pesquisa qualitativa de natureza exploratória descritiva pretende dimensionar a compreensibilidade de um texto no site do INSS antes e depois da intervençăo de Linguagem Simples em adultos de alta escolaridade. Escolheu o beneficio "Auxílio-doença" por ser o mais visitado do site do INSS e ser, também, a demanda mais recorrente em processos de direito previdenciário na Justiça Federal. Será desenvolvida em duas fases. A primeira fará um levantamento documental sobre as orientações de e-gov brasileiro a respeito do estilo de escrita de textos e a segunda aplicará o experimento de intervenção de Linguagem Simples. Serão participantes homens e mulheres na faixa etária entre 25 e 64 anos que tenham pós-graduação completa ou em curso.

Aspectos éticos: $O$ projeto e o Termo de Consentimento Livre e Esclarecido apresentados estão de acordo com os princípios e valores do Marco Referencial, Estatuto e Regimento da Universidade no que se refere às responsabilidades de seu corpo docente e discente. O Termo expõe com clareza os objetivos da pesquisa e os procedimentos a serem seguidos. Garante o sigilo e a confidencialidade dos dados coletados. Informa sobre a possibilidade de interrupção na pesquisa sem aplicação de qualquer penalidade ou constrangimento.

Parecer: Aprovado

Prof. José Ricardo Bergmann

Presidente do Conselho de Ensino e Pesquisa da PUC-Rio

Profa. Ilda Lopes Rodrigues da Silva

Comissão da Câmara de Ética em Pesquisa da PUC-Rio

Rio de Janeiro, 03 de novembro de 2020

Vice-Reitoria para Assumtos Acadêmicos 


\section{Anexo 3}

\section{Impressões de tela da seção de avaliações e resenhas de usuários do aplicativo Meu INSS, na Play Store Google.}

\begin{tabular}{l}
\hline $\begin{array}{l}\text { Meu INSS - Central... 3,3 } \\
\text { Avaliações e resenhas }\end{array}$ \\
Claudio Albuquerque \\
23/12/2020 \\
Antes estava ruim, agora péssimo. \\
O cadastro foi feito em menos de \\
noventa dias. Pra ver o requerimento \\
pede pra atualizar, exterior? .Depois de \\
fazer não entendi por quê, vem uma \\
mensagem dizendo nada de atualização \\
e um boneco atrapalhando e nao sai \\
disse. Linguagem do povo é linguagem \\
simples e sem muita burocracia. Tenho \\
que mandar umas fotos e nem icone \\
tem pra isso. Nem Por isso é que eu \\
digo. Se não é pra ajudar, não atrapalhe. \\
Se pudesse dava zero estrela. Vou \\
tentar presenciamente.
\end{tabular}

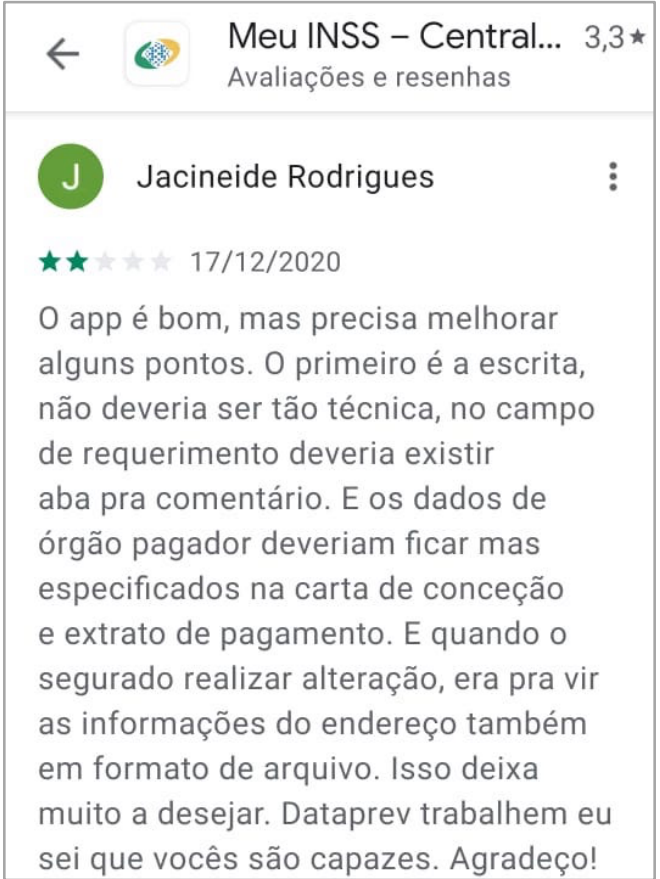

